Portland State University

PDXScholar

Spring 1993

\title{
Central America: An Attempt at Modern Economic Growth
}

Richard Kibbey

Portland State University

Follow this and additional works at: https://pdxscholar.library.pdx.edu/open_access_etds Let us know how access to this document benefits you.

\section{Recommended Citation}

Kibbey, Richard, "Central America: An Attempt at Modern Economic Growth" (1993). Dissertations and Theses. Paper 1233.

https://doi.org/10.15760/etd.1232

This Dissertation is brought to you for free and open access. It has been accepted for inclusion in Dissertations and Theses by an authorized administrator of PDXScholar. Please contact us if we can make this document more accessible: pdxscholar@pdx.edu. 
By

RICHARD KIBBEY

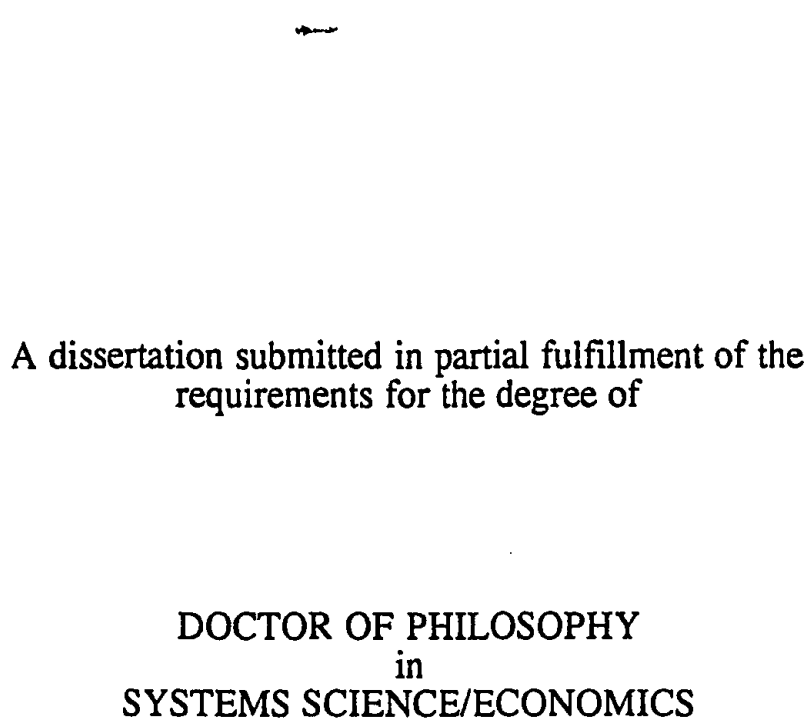

Portland State University (C) 1993 


\section{TO THE OFFICE OF GRADUATE STUDIES:}

The Members of the Committee approve the dissertation of Richard Kibbey presented June 7, 1993.

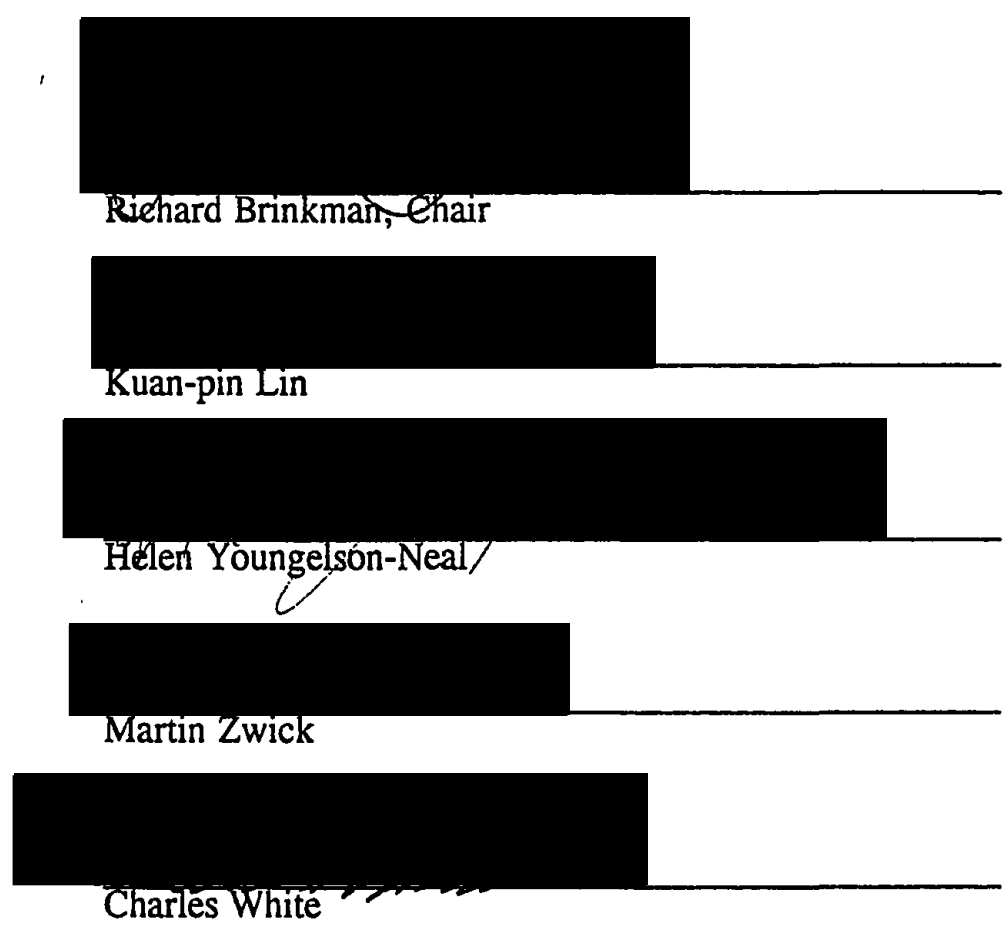

APPROVED:

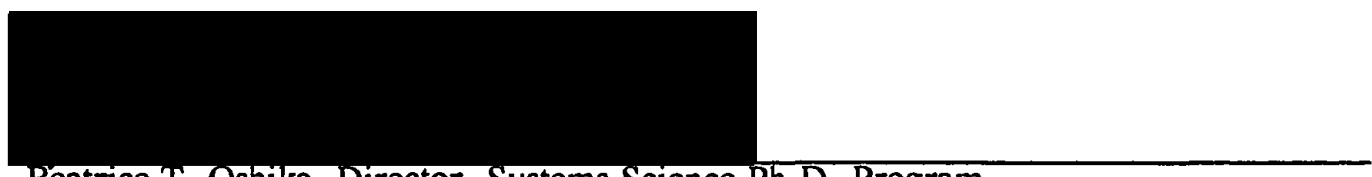

Beatrice T. Oshika, Director, Systems Science Ph.D. Program

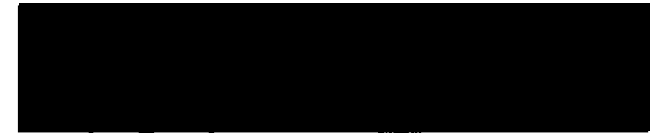

Roy W. Koch, Vice Provost for Graduate Studies and Research 
AN ABSTRACT OF THE DISSERTATION OF Richard Kibbey for the Doctor of Philosophy in Systems Science/Economics presented June 7, 1993.

Title: Central America: An Attempt at Modern Economic Growth

APPROVED BY THE MEMBERS OF THE DISSERTATION COMMITTEE:

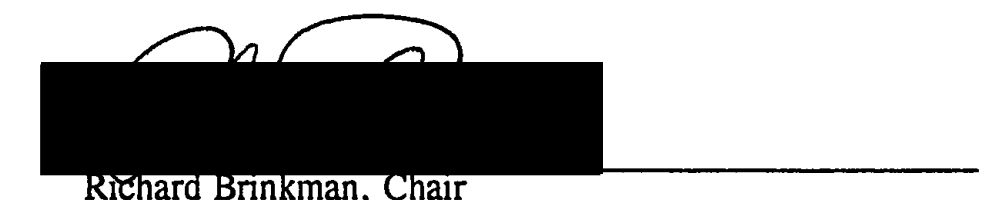

Richard Brinkman, Chair

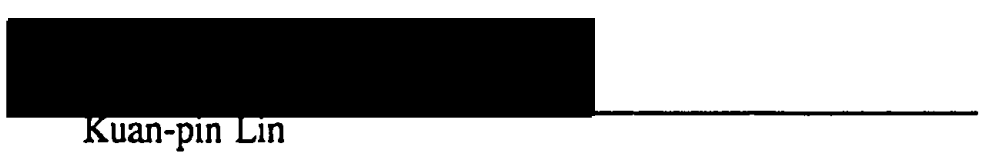

Kuan-pin Lin

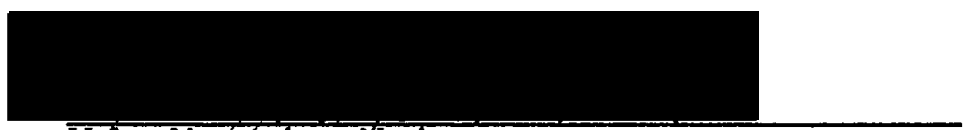

Helen Yoúngelson-Xeal

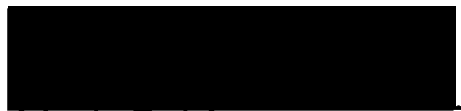

Martin Zwick

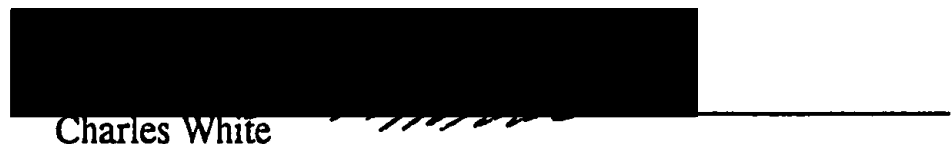

Charles White

Since World War II the five historic Central American nations, Costa Rica, El Salvador, Guatemala, Honduras and Nicaragua, underwent a period of aggregate economic growth which was followed by a collapse of dramatic proportions. All five countries experienced an economic downturn in the latter 1970s which led to several years of declining GDP and GDP per capita, together with an economic and social 
disarray which is typically referred to as "la crisis" in Central American literature.

The intent of this study is to present an argument for the position that the economic collapse of the five Central American nations was due in considerable part to their failure to pursue economic development in a manner which would generate sustainable increase. Based on a conception of modern economic growth and the statistical studies of Simon Kuznets and others since the 1940s, a set of indicators was selected for the purpose of clarifying the structural transformation referred to as economic development. This formulation of economic development was then used to distinguish the process from the simple aggregate expansion known as economic growth.

The economic development indicators were also applied to the statistical records of two east Asian economies which were comparable in many respects to the Central American nations shortly after World War II. Both Taiwan and South Korea, like the nations of Central America, emerged from the 1940s as dominantly agricultural, dualistic, importers of manufactured consumer goods.

The study begins with an examination of the growth versus development issue in economic theory, proceeds to discussion of the historical record of the two sets of nations, consideration of the indicators, evaluation of the data, and conclusions based on the data.

The development indicators clearly distinguish the records of the Central American nations from those of the east Asians. Whereas both Taiwan and South Korea illustrate the expectations of structural transformation in economic development as defined by Simon Kuznets, the Central American nations obviously do not.

Conclusions are drawn that the policies which were followed by the two east Asian nations generated the complex structural transformation which characterizes an industrialized economy. The strictly market driven policies of Central America, on the 
other hand, generated simple aggregate growth for a number of years without a change in the structure of the economy.

The study presents evidence that the Central American nations avoided structural change during the post-World War II period in anticipation of receiving the benefits of growth without undergoing the costs of a change in structure. Such a change in structure would have required reorganization of long-standing historic patterns of national social, economic and political interaction. 
TABLE OF CONTENTS

Page

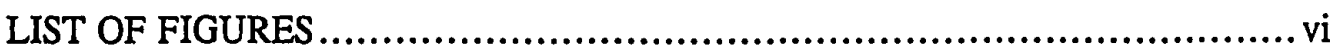

\section{CHAPTER}

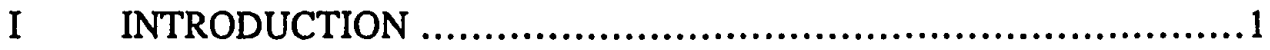

Economic Growth and Collapse in

Central America.........................................................1

Distinguishing Growth from Development........................... 10

II ECONOMIC GROWTH OR ECONOMIC DEVELOPMENT........... 18

The Neoclassical Perspective...................................... 18

The Issue ....................................................... 22

Economic Growth............................................... 28

Rigor Versus Relevancy ........................................... 30

Growth Through Removal of Obstacles ............................. 33

III THE NEOCLASSICAL THEORY EXPANDED FOR ECONOMIC

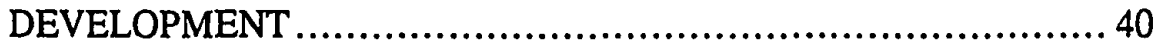

Expanded Perspectives for Development......................... 40

Adapting the Neoclassical ....................................... 43

Transformations Characteristic of Modern

Economic Growth................................................. 46

IV THE METHOD .................................................. 54

Development Data and the Role of Policy in

Development........................................................ 54

The Indicators of Growth versus Development..................... 59 
V THE CULTURAL AND GEOGRAPHIC BASIS IN CENTRAL AMERICA

Prior to World War II - Spanish Colonies and Independence 69

The Post-World War II Period........................................ 78

VI CENTRAL AMERICA: THE POST-WORLD WAR II PERIOD ....... 88

The Historical Basis .............................................. 88

The Central American Common Market ................................ 90

After the Illusion................................................ 108

VII TAIWAN AND SOUTH KOREA: THE POST-WORLD WAR II

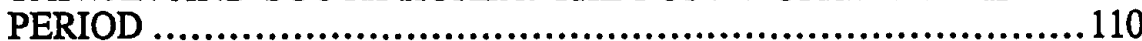

The Historical Basis .............................................110

Free Markets and Government Intervention .........................113

"The East Asian Model..." ..........................................126

VII THE STATISTICS OF ECONOMIC DEVELOPMENT AND

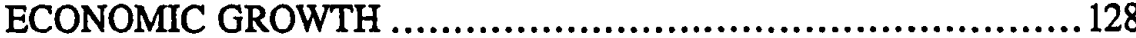

The Eastern Newly Industrialized Countries.......................128

The Central American Nations.......................................142

IX ECONOMIC GROWTH VERSUS ECONOMIC DEVELOPMENT

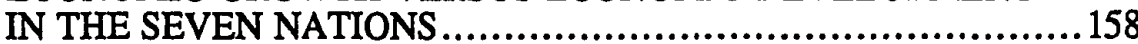

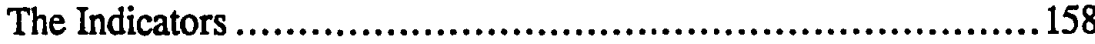

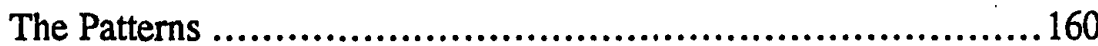

X STRUCTURAL CHANGE............................................. 176

Growth in Central America, Development

in East Asia ............................................................176

In Central America: The Yield of Growth ...........................180

Costa Rica: Growth or Development? ...............................184

Final Comments............................................... 188 


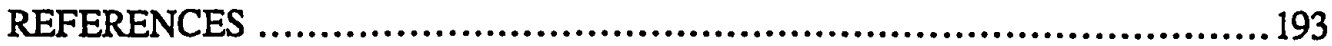

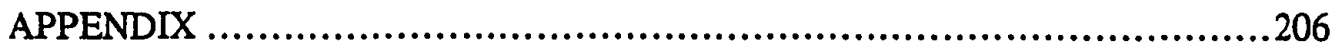




\section{LIST OF FIGURES}

FIGURE

PAGE

1. Expected Pattern of Indicators for a Developing Nation (a) and Relational Model of the Development Indicators (b) ....................... 57

2. Policy Record for the Central American Nations ...........................107

3. The History of Policy in Taiwan and South Korea ...........................125

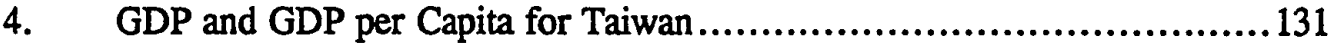

5. GDP and GDP per Capita for South Korea...............................132

6. Taiwan - The Sectors as a Percentage of GDP ...........................133

7. South Korea - The Sectors as a Percentage of GDP .........................134

8. Private Consumption per Capita............................................. 135

9. Private Consumption as Percentage of GDP..............................136

10. Savings as Percentage of GDP.............................................137

11. Gross Domestic Investment per Capita ....................................139

12. Gross Domestic Investment as Percentage of GDP ...........................139

13. Taiwan and South Korea: Rates of Literacy ............................... 140

14. South Korea: Rates of Illiteracy ......................................... 141

15. El Salvador: Employment and Earnings.....................................143

16. Costa Rica: GDP and GDP per Capita ..................................144

17. El Salvador: GDP and GDP per Capita ..................................145

18. Guatemala: GDP and GDP per Capita ..................................145

19. Honduras: GDP and GDP per Capita..................................... 146

20. Nicaragua: GDP and GDP per Capita ..................................146 
21. Costa Rica: Economic Sectors as Percent of GDP..........................147

22. El Salvador: Economic Sectors as Percent of GDP....................... 148

23. Guatemala: Economic Sectors as Percent of GDP ..........................148

24. Honduras: Economic Sectors as Percent of GDP .......................... 149

25. Nicaragua: Economic Sectors as Percent of GDP ......................... 149

26. CANs: Private Consumption per Capita .................................... 150

27. CANs: Private Consumption, Percentage of GDP......................... 151

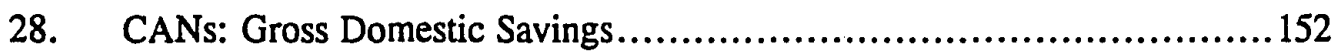

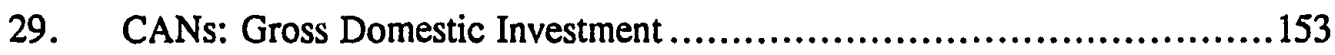

30. CANs: Gross Domestic Investment per Capita............................... 154

31. CANs: The Literacy Rate .............................................. 154

32. Costa Rica: The Illiteracy Rates........................................ 155

33. El Salvador: The Illiteracy Rates....................................... 157

34. Expected Pattern of Indicators for a Developing

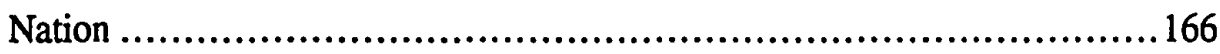

35. Gross Domestic Product ..............................................166

36. Gross Domestic Product per Capita...................................... 167

37. Three Sectors as Percentage of GDP - ENICs ............................. 167

38. Three Sectors as Percentage of GDP - CANs ................................ 167

39. Private Consumption per Capita - CANs................................. 168

40. Private Consumption per Capita - ENICs ............................... 168

41. Private Consumption as Percentage of GDP - CANs ..................... 168

42. Private Consumption as Percentage of GDP - ENICs..................... 169 
43. Gross Domestic Savings as Percent of GDP............................... 169

44. Gross Domestic Investment as Percent of GDP ...........................169

45. Gross Domestic Investment per Capita ................................. 170

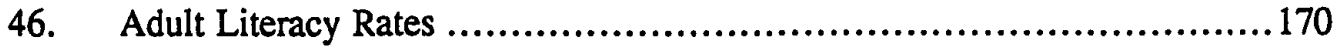




\section{CHAPTER I}

\section{INTRODUCTION}

\section{ECONOMIC GROWTH AND COLLAPSE IN CENTRAL AMERICA}

Due to increasing prices, trade in primary commodities during the latter 1940s and the 1950s generated relatively high returns for many of the less developed nations of the world. Favorable terms of trade, together with the active involvement of the developed countries which was experienced by those nations provided the basis, both financial and political, for much of the private and government expansion of the period and for expectations of more of the same.

The five Central American nations (CANs), Guatemala, Honduras, El Salvador, Nicaragua and Costa Rica, on which this study will focus, were among the recipients of the good fortune. The traditional exports, coffee and bananas, brought relatively high prices which initiated a rise in GDP. This increase provided the basis for attempts at economic expansion which continued into the 1970s. But by the late 1970s, however, the CANs had entered a period of economic and political crisis which still dominates the region.

For many of the succeeding years, the per capita GDPs of the CANs have fallen and stayed below even the relatively modest numbers of the late 1970s. Even the aggregate GDPs fell below those of the latter 1970s. For three of the nations aggregate GDP is still below that level. No one, even the Central Bankers of the five nations who are known for exaggeration of economic outcome, has described the performance of the five CANs as anything but dismal for more than ten years now. 
It is the position of this study that although the CANs underwent simple economic growth during the 1960s and 1970s, they failed to engage in the process of economic development which would have provided a sustained increase in national output. The hypothesis to be tested in this study is that the process of development of a national economy from the underdeveloped state of dominant primary production to that of a complex modern industrialized economy is in considerable part a function of the application of policy which compels structural change. In order to test the hypothesis, a set of development indicators have been chosen. These indicators, it is anticipated, are capable of distinguishing the process of simple economic growth from the complex changes in structure which characterize modern economic development. The indicators, which will be discussed in depth in chapter four, are based on the extensive statistical studies of development by Simon Kuznets during the middle and latter part of this century. 1

Although during the 1960 s and 1970 s considerable effort was expended and a great deal of money was spent on policies and programs designed to promote economic growth among the CANs, most of the expectations for economic increase and improvement since World War II have simply not been met. All five are still dominantly agricultural nations. Although per capita Gross Domestic Product grew during the early part of last three decades, it has not done so for a number of years now. Science and technology has in some respects been introduced into the economies, but in a very uneven manner and often in an almost directly imported form.

Policymaking among the CANs has often been described as having been concerned with maintaining an historically limited form of economic and political

\footnotetext{
1 Simon Kuznets has written a great deal on the structure of modern econonic growth. Many are listed in the bibliography The key reference here, though. is Modem Economic Growth: Rate, Structure and Spread. Yale University Press. New Haven. 1966. A more concise statement of the concept is to be tound in Kuznets 1973 address to the American Economic Association, published as "Modern Economic Growth: Findings and Reflections", American Economic Review. Vol. 63, June, 1973.
} 
structure. This historical basis for the post-World War II policy decisions will be discussed in chapters V and VI. In keeping with that constraint on policy, however, it will be noted that policy focused on sustaining a pleasing and unmanaged climate for investors through consistently and artificially low interest rates and through subsidized direct importation of labor-saving technology in labor surplus economies. They consistently indulged investors, in other words, at high cost to labor, to consumers and to the national economy as a whole.

A conclusion to be drawn from this study is that the economic collapse in all five of the CANs in the latter 1970s was due in considerable part to their failure to pursue economic development in a manner which would generate sustainable increase. To highlight that phenomenon, the records of two other nations will be examined in conjunction with those of the CANs. Taiwan and South Korea, two eastern, newly industrialized countries (ENICs) initiated the development of their economies during the same post-World War II period.

During the middle of this century the two sets of nations, the CANs and the ENICs, had much in common. Besides doing relatively well in sales of primary products in the post-World War II market, all of the nations were small and they had large populations relative to available resources. All seven nations also were described as having agriculture-based dualistic economies and low per capita Gross Domestic Product.

At the same time, all of the nations were understood to have been committed to the neoclassical economic model as the policy context for achieving the economic growth or development which they sought. All made quite clear in early discussion that economic and social improvement provided the contextual focus for economic policy decisions. This improvement was expected to result from the economic growth or development which was being pursued. In this they had the active support of the 
United States and of multi-lateral agencies such as the United Nations and the development banks. 2

Some thirty years later, however, the two sets of nations have come to differ profoundly. The two ENICs are widely acclaimed for their development successes. By almost any standard their development efforts have been successful. The exercise of policy in the last three decades has brought both social and economic structural change which has incorporated the majority of the population of both nations in a substantial improvement of well-being.

The ENICs have successfully resisted the external economic shocks and the slowing of global trade which profoundly affected many other developing nations. Contrarily, the CANs have all been deeply impacted by the external shocks. The dramatic changes in fuel prices in the 1970s, the debt problems and the interest rate increases of latter 1970s and 1980s, the global trade slowdowns and many other external impacts are blamed both individually and as a group for the CAN crises.

Finally, the structural changes which describe the development of the ENICs fit the expectations of modern economic growth described by Simon Kuznets in his numerous writings on the subject since the $1950 \mathrm{~s}^{3}$ In both cases, the dominance of the agricultural sector has been replaced by the industrial and services sectors. Per capita GDPs have increased substantially in both nations in spite of the accompanying population increase. Productivity has increased in all sectors and science and

\footnotetext{
2 A few of the many descriptions of the original intentions include Eduardo Lizano F. La Crisis del Proceso de Integracion de Centroamerica, Instituto de Investigaciones Economicas. Universidad de Costa Rica, 1968. Miguel S. Wionczel. "The Rise and Decline of Latin American Economic Integration". Joumal of Common Markel Studies. Vol. DX. \#1. 1970. Isaac Cohen Orantes and Gert Rosenthal. "Reflections on the Conceptual Framework of Central American Integration". CEPAL Review, United Nations, First Half 1977.

3 Simun Kuznets. Modem Economic Growth: Rate. Structure and Snread. Yale Universily Press, New Haven. 1966. And Kuznets 1973 address to the American Economic Association. published as "Modern Economic Growth: Findings and Reflections", American Economic Review, Vol. 63, June, 1973.
} 
technology has become an integral element of development expectations in both nations.

Of the two sets of nations, the two ENICs can be safely described as having successfully generated the sought-after sustainable economic development. The CANs, on the other hand, did not accomplish sustained economic growth during the decades following the 1950s, nor is the structural change which would have accompanied Modern Economic Growth in evidence.

The difference in the experience of the two groups of nations can, in essence, be said to be a function of policy decisions made by the leadership of the nations. In the broadest terms, it appears that although both the CANs and the ENICs were operating within the theoretical context of the neoclassical model, the interpretation of the role of leadership in the context of the model differed profoundly. In keeping with insistent U.S. policy regarding access to markets, the CANs followed a laissez faire or free market approach to many markets in their nations while paradoxically attempting to tightly control others. ${ }^{4}$ The labor and the capital markets, for example, were consistently controlled with the intention of maintaining a favorable climate for investment. In retrospect, it appears that such a policy tended to create an atmosphere of political manipulation and instability rather than a favorable climate for investment and economic growth.

The ENICs chose instead to consciously manage their economic growth as an evolutionary process. Writing in 1988, K.T. Li makes the point about the development process in Taiwan that "In the transition growth process...liberalization of the

\footnotetext{
${ }^{4}$ The stated requirements of U.S. development assistance is described from many points of view. Some examples include: Miguel S. Wionczek. "Latin Anterican Integration and U.S. Economic Policies", in International Organizalion in the Western Hemisphere, Robert W. Gregg, Ed., 1968. Robert E. Denham. "The Role of the U.S. as an External Actor in the Integration of Latin America". Journal of Common Market Studies, Vol. VII. A3. 1969. Michael Stohl and Harry R. Targ. "United States and the Third World: The Struggle to Make others Adapt", in Third World Policies of Industrialized Nations, Phillip Taylor.Editor. Greenwood Press. 1982. Janes D. Cochrane. "U.S. Policy Toward Recognition of Governments and Promotion of Democracy in Latin America". Journal of Latin American Studies, Vol. 4. \#2. 1972?. Susanne Jonas. "Central America as a Theater of U.S. Cold War Politics". Latin Amberican Persnectives. Vol. LX. \#3, 1982.
} 
economic system does not imply complete laissez faire or a complete abandonment by the government of all economic roles. "5 The policymakers in the ENICs made clear that their intention was to generate a dynamic process of structural development in their economies. This was done, in the long run, through the use of policy instruments which were designed to encourage investment which drew upon the use of science and science-fed technology. Earlier in the process, policy was also specifically geared to the encouragement of domestic saving, the attainment of skills and of other forms of popular engagement in the economic development process in specific targeted sectors of the economy.

This study is will examine the record of the two sets of national economies in order to evaluate the advance, or lack of advance, of each toward modern economic growth. To accomplish this, the "growth versus development" issue in economic development literature, an important part of the context for this study, will be examined.

There is no doubt that the economic growth versus economic development issue is a vital one with a notable history. It is enmeshed in current concerns about tragic economic conditions in many third world nations and it also extends back to immediately post World War II theoretical discussions about the adequacy of neoclassical growth theory. It is not a new issue. From the point of view of this study, however, it is an issue which has taken increasing importance over the recent decades and is relevant to the comprehension of the economic problems confronting Central America.

In subsequent chapters the policy approaches used in the two interpretations of the neoclassical model will be considered. The two ENIC nations seem to have taken

\footnotetext{
${ }^{5}$ K.T. Li. The Evolution Of Policy Behind Taiwan's Developneent Success. Yale University Press, New Haven. 1988. p. 141.
} 
the neoclassical perspective as a guide, a basis for conceptualizing economic goals over time, and within which to generate the conditions for decision-making by market participants. Though both nations depended upon market decisionmaking as the ultimate tool for allocation decisions, both substantially guided national and sectoral allocation through government intervention. The CANs appear to have taken an alternative approach. They can be described as having taken the theory as a recipe, a method in itself for generating growth. And, consistent with the theory, they saw economic growth not as a dynamic process of structural change, but as a simple cumulative process, a process of increase without the necessary structural change. Decisionmaking on both national and sectoral levels for the CANs was left to the market.

Edelberto Torres-Rivas, an active and well published Costa Rican economist, has stated clearly in numerous writings that what encapsulates the long list of specific failures in the process is the observation that in the final analysis the economic structure in Costa Rica did not change. It did not develop toward that of a 'modern' economy. 6 Torres-Rivas suggests that much of the blame for the failure of development lies with the inappropriate modeling of the process with respect to the specific requirements of Central American development needs. By that he means to challenge the dependence on unmanaged market decisionmaking in lieu of intentional policy geared to the specific needs of the five nations.

The World Bank, on the other hand, represents the orthodox economic perspective on the problem from the vantage point of the industrialized nations. In this case the economic crisis in the 1980s is seen as primarily the result of unfortunate external impacts - fuel prices, the world debt crisis, ill-fated internal wars and so on.

\footnotetext{
${ }^{6}$ See for example. Edelberto Torres-Rivas. Crisis del Poder en Centmamerica. San Jost, EDUCA. 1989. The english reader can find similar conclusions in his "The Central American Model of Growth: Crisis for Whom?", Latin Allerivan Perspectives. Vol. VII. 1980.
} 
In fact, when the decades of the 1960s and 1970s in Central America are mentioned in World Bank literature, it is to describe them as successful periods of economic growth, not as periods of unsuccessful economic development which laid the ground for the crises of the 1980s, as is seen by Torres-Rivas. ${ }^{7}$

The theoretical background for this study includes both the neoclassical perspective and the expansion of the neoclassical theory represented by Simon Kuznets and others who focus on the need for a dynamic concept of development. The essential question is that which is often addressed in the literature as the "growth versus development" argument. The argument centers on the fact that neoclassical theory is built upon a model of the national economy which is static in nature. Thus, with respect to time, at best the neoclassical model comprehends the subject economy strictly at distinct points in time by comparing only a set of static states of the economy.

Those who are concerned with the dynamic aspects of economic expansion, on the other hand, argue that neoclassical theory presents a model which is inadequate to comprehend the changes over time. In general, the argument suggests that long-term sustainable economic development requires that the social and economic structure of the nation change in order to support the inevitably multi-faceted process of economic development. Thus, since the neoclassical model is not capable of representing the dynamic processes, it requires at least a supplemental model of the development process and at most a completely different model which portrays economic development as a dynamic process.

\footnotetext{
7 In terms of the perspective described hers, all of the World Bank studies and reports of Central America are consistent. A couple of specific references, however. are: El Salvador: Country Economic Memorandum. 1989. where the fall in per capita income since 1978 (after eighteen years of growth) is described as due simply to the internal war: and Trade Liberalization and Economic Integration in Central America, 1990.
} 
Recognizing that economic development is, of necessity, a dynamic process, a number of theorists in recent years have suggested that a development theory must comprehend the process of change itself. Generally the concern for that comprehension is related to the intent of guiding, or managing, the change.

The neoclassical theory, on the other hand, treats the process of change as a black box where only input and output can be noted. The process - a function of the market - is a 'natural' one which must be left to function unimpeded. In terms of the question posed by this study, it is the way those conclusions were interpreted which is the key to the radically different results in the two sets of national economies.

The Central American leadership, in concert with clearly stated admonitions of the U.S. government, chose to interpret the neoclassical theory literally. Markets were left to work essentially untended. Government functioned primarily to provide the infrastructure required by the markets and thus indirectly by foreign suppliers of capital. Intervention by government was essentially limited to moves which would encourage investment without discrimination.

The original conditions in Central America were far from those assumed by the orthodox model. Competition, for example, in nearly all markets was a function of power, both political and economic. The same was true of South Korea and Taiwan, of course. That is virtually part of the definition of underdevelopment. But whereas in Central America the large gap between the theoretical and the real world conditions was ignored, the ENIC nations recognized that what was assumed in the theory would have to be encouraged and created in the real world economy.

The ENICs located the neoclassical model within a larger context. Specifically why or how they did that is not within the purview of this study. Recent books and articles cite the teachings of Dr. Sun Yat-Sen in Taiwan and Confucius in both Taiwan and S. Korea as important to the particular form of government intervention in the 
economies. ${ }^{8}$ What is important to this study is that for the ENICs there appears to have been an overview which informed and provided goals for policy decisions, which guided the application of the theory.

Thus, given the conceptual distinction between growth and development, the comparison of the experience in structural development of the two economies requires that the structural relationships be examined over time. This implies a theoretical perspective which goes beyond the neoclassical as such.

\section{DISTINGUISHING GROWTH FROM DEVELOPMENT}

The argument as to whether an economy developed or simply grew requires that indicators be established which will dependably distinguish economic growth from economic development. The aggregate indicators of the neoclassical model, GDP and GDP per Capita, are the archetype growth indicators. At best these measure only the aggregate expansion or contraction of the national economy. They give no indication of change within the structure of the economy, and no indication of the changes which mark the development of the economy from the level of mainly producing traditional primary goods, to that of an industrialized modern economy.

Indicators which distinguish growth from development must present a disaggregated view of the economy in order to allow evaluation of the structure and of the changes in the structure which should take place over time. The work of Simon Kuznets on the structure of modern economic growth provides a foundation for conceptualizing economic development. Kuznets' work approaches the process of

\footnotetext{
${ }^{8}$ Two examples are Paul W. Kuznets. "An East Asian Model of Economic Development: Japan. Taiwan and South Kores". Economic Development and Cullural Change. Vol. 36, \#3, 1988 Supplement p. S35; and K.T. Li. The Evolution Of Policv Behind Taiwan's Development Success. Yale Universily Press. New Haven. 1988. pp. 9. 24-25, 38-39.
} 
development from the empirical side. He saw his work as recognizing the historical changes in structure which accompanied the economic expansion of recent historical periods.

Walt W. Rostow described the process of economic development in a work published in 1990, in which he asserts that his concept of the 'mature' economy is comparable to the Kuznetsian notion of modern economic growth ${ }^{9}$ The basic question for the comprehension of economic development, says Rostow, is whether it is possible to define it in terms of GNP per Capita. He observes that it is not possible to comprehend development in such aggregate terms and that ultimately it is necessary to define it "...in terms of the degree to which the pool of then-existing technology had been efficiently absorbed" in the economy.

For Rostow, as similarly for Kuznets, the stage of economic maturity has been achieved "when a society has effectively applied the range of modern technology to the bulk of its resources." 10 The indicators to be used in this study are based on the statistical studies of the historical patterns economic development which were published by Simon Kuznets in the 1960s and 1970s. Kuznets found that the indicators of development included GDP per Capita, the relationships among the three major economic sectors, consumption, savings, investment and education. That list is by no means exclusive. There are other indices among the Kuznetsian findings, but these are key in the list.

In this study the indicators which have been examined over time for the seven nations are:

\section{- GDP and GDP per Capita,}

\footnotetext{
${ }^{9}$ Walt W. Rostow. The Stages of Economic Growih: A Non-Communist Manifesto. Third Edition. Cambridge. Cambridge Universily Press, 1990, page 242.

${ }^{10}$ Walt W. Rostow. The Stages of Economic Growth: A Non-Communist Manifesto, Third Edition. Cambridge, Cambridge Universily Press. 1960. page 59.
} 
- Agriculture, Industry and Services Sectors as Parts of GDP,

- The Use of Output in the form of, Consumption - Per Capita and as Part of GDP Savings as Part of GDP and - Literacy. Investment - per Capita and as Part of GDP

These indicators and their value for distinguishing economic development in an emerging nation will be discussed in the fourth chapter.

If Kuznets, Rostow and others were right about the economic development process, these indicators can be expected to illustrate a significant change in structure in the developing nations during the post-World War II decades. These changes should lead to characteristics in the developing economy which are consistent with what Kuznets refers to as modern economic growth. The Kuznetsian perspective suggests that in the latter twentieth century the process of developmental change requires that the leadership of the nation manage the economy with development as a clear intention. The policy intervention, in the case of the ENICs, was oriented to managing the allocation of resources within the sectors and to the creation of infrastructure within the economy as a whole in order to make best use of the resources in the expansion of the base for the economy.

Howard Pack and Larry Westphal, in an article in the Journal of Development Economics, discuss the selective intervention in the Korean case which "...is focused on industries judged to be in Korea's dynamic competitive advantage". 11 By "dynamic Comparative advantage" the writers mean to characterize the strategy of exploiting the comparative advantages of one level of primary production or basic industrial production while building a comparative advantage in a technically higher level industry. They refer specifically to the process by which "infant industries are developed by market agents acting in response to non-neutral promotional policies and

\footnotetext{
11 Howard Pack and Larry Westphal, "Industrial Strategy and Technological Change". Joumal of Development Economics, Vol. 22. 1986, pages 87-128.
} 
under the strong influence of direct non-price dominated interventions in decision making and resource allocation. Other industries - suppliers of inputs and users of outputs - are affected by these measures insofar as their behavior is constrained or otherwise conditioned by the selective interventions to foster infant industries. " 12

The important point in this process of government intervention in, or management of the development process, is that in South Korea, as in Taiwan, "The monitoring (or intervention) process has assured that (investments) are both privately and socially profitable in the medium term, though not always in the short term." 13 It is the emphasis on the 'socially profitable' aspect of the allocation of resources which distinguishes the policy of the ENICs from that of the CANs.

For the ENICs, government intervention in the economy was specifically intended to accomplish the characteristics of modern economic growth as described by Kuznets. That is, as will be discussed in chapter seven, the management of the development process for the ENICs was expected to result in a sustained increase in GDP, together with a more equitable income distribution, an increase in education and skills in the population, an increase in technological capacity for the economy, and an increase in economic welfare for the nation as a whole.

This implies intentional management of the economy in a manner not unlike that of a new business venture. The national resources at hand must be marshaled and allocated with the intention of providing the basis for expansion in the next phase. The Kuznetsian approach emphasizes the importance of the incorporation of knowledge through application of science and technology as the means of leverage through which a sustained increase in total output can take place. This implies continued investment in

\footnotetext{
12 Howard Pack and Larry Westphal. op. cit.. page 98.

13 Howard Pack and Larry Westphal. op. cil.. page 101.
} 
education and other resources for the incorporation of technology into the production process.

As will be seen in subsequent chapters, examination of the historical data for the seven countries illustrates dramatic differences in the two sets of nations. While the pattern in the indicators which is represented by the ENICs confirms the expectations drawn from Kuznets' studies, that of the CANs illustrates clear failure to move toward modern economic growth.

The ENICs, with policies intended to change the structure of their economies, will be found in this study to have generated the changes required for economic development. In the decades since World War II, that is, the two ENICs pursued policies which created economies which will be found to approximate the profile of economies characterized as modern economic growth.

The five CANs, on the other hand, pursued policies geared strictly to the aggregate growth of their economies, leaving specific investment decisionmaking to the market process. There was no overt management of the economies for the purpose of allocating resources for long term development. They depended entirely on the market to make allocation decisions for economic expansion. The resultant statistics show a number of years of aggregate GDP growth, though GDP per Capita was disappointing throughout the period, followed by the collapse which is characterized as "the crisis" in Central America. With the partial exception of Costa Rica, the CANs uniformly fail the tests of modern economic growth drawn from the findings of Kuznets.

Presently, among the CANs, the focus on export-led-growth is being understood as the policy which, if applied properly, will - like yeast in bread - cause the economy to rise. Exportation is being pushed as the recipe for the extraction of the CANs from the crisis. This essentially reductionist view of the national economies sees them as entities which, when properly adjusted, will arrive at stable forms which will simply 
increase in size. The World Bank, The IMF and the United Nations have been producing studies, evaluations and specific proposals regarding the correct actions for getting the nations 'back on the track' 14

The United Nations Development Program is engaged in seeking renewed financial help for the governments and for the regional efforts to rebuild the collapsed economies. The striking thing about the approach is that the efforts by both the UN and the five CANs are very much like those of the 1950s and early 1960s. These are the policies which set the tone for the subsequent years of unstable growth.

As a result of the comprehension of the process described above, it appears that the CANs are condemning themselves to, at best, another round of static comparative advantage and of aid and external investment, in hopes of floating like flotsam on the tide of world trade. This strategy has paid off very poorly in the past. In Central America, for example, although the 1960 s generated considerable growth in Gross Domestic Product, their share of world trade was consistently poor. ${ }^{15}$

The conclusions of this study suggest that the resolution to the current economic crisis for the CANs lies in the pursuit of policies which will encourage the structural change necessary for modern economic growth. This refers to engagement in the complex of activities which use current comparative advantage to provide the economic

\footnotetext{
14 A few cases in point include; the United Nations Developnent Progranme's Cooperacion Para Desarmollo: El Salvador (Internal Document - 1989); and Cooperacion Para Desarrnllo: Guatemaln (Internal Document - 1989) and the Special Plan of Economic Conperation for Ceniral America where the theme is the need for external financial assistance to reestablish the "...successful pattern of development (which) exhausted itself a decade ago in Central America." (Page 4) The latter document was developed in the context of the effort to reestablish the all but defunct Central American Common Market in 1988; the World Bank's Interim Report on Lending for Adiustment. 1988. where the two prime indicators are given as GDP growth and Export growth, the internal documents. Trade Liheralization and Economic Inlegration in Central America, 1990, and El Salvador: Country Economic Memnrandum. 1989. where the fall in per capita income since 1978 - after eighteen years of dramatic growth is described as due simply to the internal war (p. 1, ff.).

15 Richard Kibbey. "Constant-Market-Share Analysis of Central American Export Growth", 1986. Paper prepared for a seminar on International Economics with Prof. Helen Youngelson-Neal at Porlland State University. Also see Mario Moravec. "Exports of Latin American Manufactures to the Centers: Their Magnitude and Significante". CEPAL Review, Vol. 17, August. 1982; Joseph Grunwald. ed.. Latin Amerien and the World Economy, London. Sage Publications, 1978; and United Nations. Handhook of Intermalional Trade and Development Statisties. New York. United Nations. 1980.
} 
resource base for the next stage in the development process. It also refers to the establishment of policy which involves investment in education, encouragement of increased domestic saving and investment, pursuit of increased income equity, and encouragement of resource allocation directed toward incorporation of technology in domestic production.

The study does not deal with the many forces which lie beyond the realm of domestic economic policy per se. Both sets of economies have been subject to an array of impacts which certainly affected the economic records, and which have been said to account for the crisis in Central America in spite of any intention on the part of government leadership.

The global economy is commonly cited as the reason for the crisis among the CANs. The international energy price increases of the 1970s, and the global debt problems of the 1970s and 1980s, for example, have been blamed for the collapse of the Central American economies in the 1970s. It is clear that both did have large impacts on those economies. It is also apparent that the Central American economies were considerably more vulnerable to the state of the global economy in the 1970s and 1980s than were the ENICs. By the time the global economy began adjusting to the expansion of the earlier post-World War II period, the ENICs had engineered domestic economies with sufficient internal capacity to allow advantageous adjustment to the global impacts.

The civil wars in Central America are also often cited as causes for the crises. Yet it is entirely reasonable to suggest that the civil wars are more likely the result of the failure to promote structural change than they are explanations for the disappointing growth in the region. Subsequent chapters will reveal that although only three of the five nations suffered civil wars (El Salvador, Guatemala and Nicaragua), the record of the collapse in output in the latter 1970 s is strikingly similar for all five. 
This study proposes to deal only with the record of structural change, or the lack of structural change, in terms of the policy intentions on the part of the leadership in the seven nations, not with the myriad of explanations and alternative interpretations which are offered for the successes of the ENICs and the failures of the CANs. No attempt is made here to account for the wars, the global economy, the vicissitudes of the international markets, weather, or any of the many other environmental circumstances which inevitably affected the history of both the growth and the development efforts.

Rather, the study is offered as an attempt to comprehend the economic collapse of the five CANs in the latter 1970s in terms of the inadequate economic growth policy. This deals with, in other words, issues of fundamental causes rather than with the many proximate causes which impacted and affected the national economies as well.

In the next two chapters, chapters two and three, the growth versus development issue in the literature is reviewed. Chapter four describes the method which has been used in the study, including explanation of the indicators which have been chosen. The history of the Central American economies will be described in chapters five and six in order to elucidate the behavior of the leadership in economic policymaking during the post-World War II period. Similarly, the recent economic histories of Taiwan and South Korea is treated in chapter seven.

Subsequently, chapter eight presents the statistics of development and of growth as represented by the ENICs and the CANs. An evaluation of the results is made in chapter nine, followed by the concluding remarks in chapter ten. 


\section{CHAPTER II}

\section{ECONOMIC GROWTH OR ECONOMIC DEVELOPMENT}

\section{THE NEOCLASSICAL PERSPECTIVE}

Most writers on the subject in development economics recognize a clear distinction between economic growth and economic development. That that distinction is understood to be important by all sides in the discussion, there can be little doubt. A state-of-the-art neoclassical text on the Economics of Development addresses the question in what will be seen to be a revealing manner. ${ }^{1}$ The major part of the first chapter in that text deals with clarification of the distinction between "economic growth" and "economic development".

The definitions which are offered make the distinction clear. ${ }^{2}$ "Economic growth", say the authors, "refers to the rise in national and per capita income and product." This seems to be a straightforward notion with which there is likely to be little disagreement at the superficial level at which the comment is made.

Disagreement appears in further development of the idea, in the question of whether or not the theory should account for more than growth in the sense of simple increase.

Neoclassical economists tend to simply assume that development accompanies growth and that the concepts are synonymous. On the other hand, when restricting themselves to a theoretical perspective, neoclassicists define development (structural change) out of the model. J.E. Meade, for example, in the Introduction to his A Neo-

\footnotetext{
${ }^{1}$ Malcolm Gillis, et al. Econonics of Develonment. W.W.Norton and Co., New York. 1983. Prepared under the auspices of Harvard's Institute for International Development.

2 Gillis, et al. op. cit.. p. 7 if
} 
Classical Theory of Economic Growth, states that one is likely to have a "...desire to watch this system grow through time... (In the context of this theoretical perspective, however,) we shall confine ourselves to watching the process of growth on the assumption that the growing system remains in equilibrium. "3 The components of the growing system, in other words, simply increase in constant proportion with the economy as a whole. From the point of view of the neoclassical theory, Meade is telling us, development as change in the structure cannot be accounted for.

The authors of Economics of Development tell us, as do many others writing on the subject, that "Economic development, in addition to a rise in per capita income, implies fundamental changes in the structure of the economy". ${ }^{4}$ This part of the definition is not so straightforward, nor is there wide agreement, even at this superficial level, as to what such a change in structure would entail.

The authors go on to list the fundamental changes which are likely to accompany economic development. The three major ones are, 1) a rising share of industry in national product, 2) an increasing percentage of people living in cities and 3) the population as a whole must be participants in the process which gives rise to the changes in structure. The list includes other structural changes as well. Those include acceleration (then deceleration) of population growth, alterations in the structure of the age of the population, and alterations in the consumption patterns.

Later in the chapter the authors recognize that their list of anticipated changes in the process of economic development is similar to the concept of modern economic growth as described by Simon Kuznets. With the exception of three references to specific statistical contributions by Kuznets later in the book, however, Kuznets'

\footnotetext{
3 J.E. Meade. A Nen-Classical Thenry of Economic Growth. Unwin University Bouks. London, 1964. p. 3.

${ }^{4}$ Gillis. et al, op. cit.. p. 7 ff
} 
concept of modern economic growth is pursued no further in the Gillis text on economic development. The significance of this minimization becomes clear with the recognition that through the decades of his concern with modern economic growth Kuznets stated consistently that such growth could not take place without structural changes such as those described above. These were not simply desirable or likely changes, they were necessary characteristics of economic "growth" in this period. ${ }^{5}$

The Gillis text is based primarily in the neoclassical theoretical perspective. This is a static model of national economies which cannot deal with the dynamic changes in structure which are necessary to Kuznets' MEG. Nor, of course, can it deal with the implications of 'economic development' as described in the text itself. Even so, this text continues to discuss the characteristics of development in the introductory chapter as though they are somehow integral to the model of economic growth on which the text is based.

The matter becomes dramatically clear in the second chapter which is entitled "Obstacles To Development". Here, Gillis, et al, shift from describing the characteristics of development as objectives to describing them as inherent in an underdeveloped national economy. These are not changes in the economy which are to be pursued. They are changes which will automatically appear when the obstacles, economic, government, social and international, have been removed.

Given that the neoclassical model is a static one it is to be expected that the accompanying concept of 'development' is one which attempts to identify the attributes of an underdeveloped national economy which appear to keep it from functioning like a

\footnotetext{
5 See for example, Simon Kuznets. "Modern Economic Growth: Findings and Reflections". Americann Economic Review. Vol. 63. June 1973. pp. 247-258. Also see Simon Kuznets, "Toward a Theory of Economic Growth". in National Policy for Economic Welfare at Home and Ahrond, Rohert Lekachman. Editor. New York. Russell and Russell. Inc.. 1961. In that article Kuznets cites several publications dating from the late 1940s which build toward this immediate predecessor to his modem economic growth argument. The MEG perspective can be found in Kuznets' Modern Economic Growth: Rate Structure and Spread, New Haven. Yale University Press. 1966. and in succeeding articles and books cited in the bibliography.
} 
fully developed market economy. The solution, then, is essentially the removal of those obstacles. Once the obstacles are removed, it is assumed, the economy will naturally begin to function as a developed market economy.

Having described development, clearly distinguishing it from growth in chapter one, the Gillis text then uses the term 'development' throughout the balance of the text as though the terms were interchangeable. The authors state that "In the definition used in this book, economic development includes both growth and wide distribution of the benefits of growth." 6 They go on to rnake clear that distribution of the benefits of growth is a function of the policymakers, it is not an integral part of the growth process. For that reason, the first topic under "Patterns of Development" in chapter three is Gross National Product. "The great advantage of the GNP concept", they tell us there, "is that it encompasses all of a nation's economic activity in a few summary statistics that are mutually consistent. ${ }^{17}$ That GNP, a strictly growth measurement, is the key measure of development for these authors leaves the reader with no doubt that the terms 'economic development' are simply being used to mean 'economic growth'.

Neoclassical theorists reduce the issue to one of static and comparative static models. Many have specifically addressed the problem. In a 1968 article on development Gottfried Haberler stated that "...it is not true that a static theory, because it is static, is debarred from saying anything useful about a changing and developing economic world. There is... 'comparative statics' (which is at least helpful) in dealing with a changing situation. ${ }^{18}$ He admits that what can be done in a dynamic environment with a static theory is limited. A dynamic theory, he argues, would be

\footnotetext{
${ }^{6}$ Gillis, et al. op. cit., p. 26.

${ }^{7}$ Gillis, et al, op. cit.., p. 41.

8 Gottfried Haberler. "International Trade and Economic Develupment", in James D. Theberge, ed. Economics of Trade and Develonment. John Wiley and Sons. New York. 1968. p.106.
} 
more appropriate. The best he can offer in the realm of trade theory, however, is "the rudiments of a dynamic theory" which was described by Hla Myint and which was based in the classical perspective of Adam Smith and J.S. Mill. ${ }^{9}$

Bruce Herrick and Charles Kindleberger, in the fourth edition of their Economic Development text, deal with the problem by first clearly describing the difference between growth and development. Thereafter they state that in any case they cannot imagine the possibility of growth without development. In fact, as will be argued in later chapters, growth without development is entirely possible for a limited time, though it is by no means necessarily desirable. In any case, Herrick and Kindleberger also end up thoroughly confusing the implications of the two terms relative to neoclassical theory by using them interchangeably. 10

\section{THE ISSUE}

Recognizing that economic development is, of necessity, a dynamic process, a number of theorists in recent years have suggested that a development theory must comprehend the process of change itself. As is to be expected in such a modeling endeavor, the concern for comprehension of the process is a function of the intent to guide or manage the change.

The neoclassical theory itself, on the other hand, treats the process of change as a black box in which only input and output can be noted. The issue of technological change and dynamic change in structure are avoided. From that perspective, the

\footnotetext{
${ }^{9}$ Haberler, op. cil., p.106.

${ }^{10}$ Bruce Herrick and Charles P. Kindleberger. Economic Develonment. McGraw-Hill. New York, 1983 (4th Edition). See especially pages 21 and 22, and pages 49 through 52 where, in the section entilled NEOCLASSICAL THEORIES OF ECONOMIC DEVELOPMENT, the reader is referred to Chapter 2 where "Neoclassical theories of economic growth were described..." then treated to a description of the classical political-econounic perspective which "modem neoclassicists...largely ignore."
} 
process of development - a function of the market - is a 'natural' one which is best left to happen unimpeded.

If the basic neoclassical model for economic growth (as distinct from economic development) is to be accepted at face value, the implications are clear. All markets must function without intervention. In fact a major effort must be made to remove obstacles to free markets in order to as nearly as possible approximate 'perfect' competition. Economic participants must be expected to behave predictably rationally. Intervention by government is to be thoroughly circumscribed. Although the model assumes a closed system, foreign trade will function through open markets as the 'engine for growth'... and so on. These observations are to be found in any of the orthodox neoclassical growth or 'development' texts, including those mentioned in the previous section of this chapter.

W. Arthur Lewis is one of the undoubtedly orthodox economists who recognized and discussed some of the problems the neoclassical model has in comprehending economic underdevelopment. After describing the temporally circumscribed character of the theory in his Theory of Economic Growth, Lewis pointed out that we must look beyond the boundaries of contemporary economic theory when we are concerned with long term issues. 11 "Economic growth (better understood as economic development from the point of view of this study)", he says, "depends upon attitudes to work, to wealth, to thrift, to having children...and so on." On the whole the book represents an attempt to transcend the narrow limits of neoclassical theory, to incorporate much of the range of concerns which orthodox economists have defined out of their theory.

11 W. Arthur Lewis. Theory of Economic Growth, Unwin Universily Books, London. 1955. pages 12-18. 
Lewis' book is primarily focused on "the growth of output per head...", the archetype neoclassical concern. ${ }^{12}$ Many pages are devoted, however, to arguing that by narrowing their field to the study of a very limited range of "proximate causes" (as distinct from underlying causes), economists have limited themselves to building tools for short-term analysis only. "If we are concerned with long term studies", the author argues, "we have to look beyond the boundaries of contemporary economic theory." 13 Another orthodox economist who clearly recognizes the need to transcend the limits of theory rather than using the theory as a rule book is Hla Myint. Haberler is described earlier in this chapter as having mentioned Myint who, in 1968, recognized the classical economists, Adam Smith and J.S. Mill, as the unique contributor of "the rudiments of a dynamic theory". 14 That Myint is one who would agree with Lewis can also be seen in his 1982 writing on the development experience of Taiwan. In that article he states that that country's experience "...points to a number of weaknesses in the conventional 'International Trade Theory' approach." 15

In the case of Taiwan, he states, in order to take advantage of the abundant labor supply it was necessary for the government to make institutional adaptations in other realms in order to move toward a process of industrialization which would avail itself of that "comparative advantage". In other words, he recognized that the mere removal of obstacles to allow the latent forces of the market to assert themselves would have been inadequate to activate the comparative advantage.

\footnotetext{
12 Lewis. op. cit., p.10. Methodology.

13 Lewis, op. cit., p.13.

14 Gottfried Haberler. "International Trade and Economic Develupment". in James D. Theberge. ed: Economics of Trade and Develonment. John Wiley and Sons. New York. 1968. p.106

15 Hla Myint. "Comparative Analysis of Taiwan's Economic Development With Other Countries", in Exneriences and Lessons of Economic Development in Taiwan, Kwoh-ting Li and Tzong-shian Yu. Editors. Cinica Academica. Taipei, Taiwan. 1982. pages 71 and 72 .
} 
Another orthodox economist, Michael Todaro, has concerns about the theory which are closely related to those of both Lewis and Myint. In essence he suggests that a development model must recognize and respond to the unique domain in which the development is to take place.

Writing in an article on "Current Issues in Economic Development", he places that requirement in an historical context when he describes the "Unfortunate (development) experience of (recent) decades of many third world nations". $16 \mathrm{He}$ points out that "While the thought processes of (orthodox) economics may have universal validity, the models themselves are often culturally and institutionally specific." Orthodox economists, for example, tended to pay little attention to the fact that third world economies are likely to be highly fragmented and that disequilibrium rather than equilibrium relationships predominate. "Development economists (therefore)...must always be searching for ways to adapt their traditional concepts and models to the very different structural and institutional settings of the third world nations." 17

In the 1940s and 1950s Simon Kuznets wrote actively about his concern that the generally accepted aggregate indicators of economic growth, those indicators which provided the motivation for data collection, were inadequate to model a growth process which involved substantial structural reorganization in the growing economy. ${ }^{18} \mathrm{He}$ argued that in order for 'economic growth' to represent a sustainable increase in

\footnotetext{
16 Michael P. Todaro. "Current Issues in Economic Development", in Economic Persnectives, Maurice Ballabon. Editor, Harwood Academic Publishers. New York. 1979. pages 221-252. Also see Michael P. Todaro, Economic Development in the Third World, Second Edition. New York, 1981.

17 Todaro, op. cit., p. 225.

18 For example, see Simon Kuznets. "Toward a Theory of Economic Growth". in National Policy for Economic Welfare at Home and Abrand. Robert Lekachman. Editor, New York. Russell and Russill. Inc., 1961. In that article Kuznets cites several publications dating from the late 1940s which build toward this immediate predecessor to his MODERN ECONOMIC GROWTH argument. The MEG perspective can be found in Kuznets' Modern Economic Growth: Rate Structure and Spread, New Haven. Yale University Press. 1966, and in several succeeding articles and bonks ciled in the bibliography.
} 
national economic welfare, the economy must experience "major changes in the shares of the various components of national product and (concomitant changes) in the grouping of populations". 19

This implies a concept of 'growth' which transcends the static orthodox model. Kuznets suggests here and in later writing that the aggregate measures are inadequate to account for or to allow accurate policy guidance of the process. In 1980, writing on the "Driving Forces of Economic Growth" Kuznets states quite clearly his conclusions that since "economic (development) is a socially bound process"...the social as well as economic costs of the process must be monitored for "...guidance in our interpretations and in policy implications. $" 20$

It is clear that the issue is and has been for some time a significant one among mainstream neoclassicists. Yet since World War II economic 'growth' policy in many third world nations has been limited to the narrow, literal interpretation of the model which disallows guidance of the process. There are many more critics of the model who do not refrain from stating clearly that a static theory which is concerned with aggregate growth of the economy as quantitative statics is simply inadequate to portray the qualitative dynamics of the development process.

Shortly after World War II Gunnar Myrdal, an economist and active public servant, wrote a great deal about the inadequacy of the "inherited" theoretical approach to deal with economic underdevelopment. 21 In a work of the mid-1950s he states that "In the main, economic theory has not so far concerned itself with the problems of

\footnotetext{
19 Simon Kuznets, Modern Economic Growth: Rate Structure and Spread, New Haven. Yale University Press. 1966, page 17.

20 Simon Kuznets, "Driving Fores of Eeononic Growth: What Can We Learn from History?", Wellwirtschafliches Archiv, Band 116. Heft 3. 1980. pages 427 \& 428.

21 See, for example, Myrdal's Development Theory and Underdeveloped Regions. 1958. Reference to many of his other writings will be found in the bibliography as well as elsewhere in the lext of this study.
} 
underdeveloped countries. If, nevertheless it is uncritically applied to those problems, the theory becomes wrong. " 22

Myrdal's "starting point (in this particular text) is the assertion that the notion of stable equilibrium is normally a false analogy to choose when constiucting a theory to explain the changes in a social system." 23 This position is essentially supported by his argument that circles of causation in the economic realm are as likely to be vicious as they are to be virtuous. Thus he concludes that in actuality, as distinct from within the dominant theory, "the play of forces in the market tends to increase, rather than to decrease, the inequalities between regions (whether within or between national economies). Much of the (orthodox) theory is a rationalization of the dominant interests of the industrial countries where it was first put forward and later developed." 24

Myrdal tells us that he foresees, correctly or not, "a new orientation in economic theory toward greater realism... and final liquidation of...the free trade doctrine and the stable equilibrium approach". Even so, he says, he has no illusions that it will ever be possible to fit such a comprehensive new theory into a neat, strictly economic, model. The relevant "noneconomic" variables and the relations between them are too many, he says, to permit that sort of heroic simplification.

Writing in what appears to be clear basic agreement with Myrdal with respect to the inapplicability of the heroic simplifications and assumptions of the neoclassical model, Francois Perroux presents a much more articulate theoretical analysis of the model itself in his development of the case for abandonment of "the static expression of

\footnotetext{
22 Myrdal, op. cil.. p. 111.

23 Myrdal. op. cil.. p. 25.

24 Myrdal, op. cit.. p. 38 and 111.
} 
growth in orthodox economics". 25 He goes through a long list of theoretical reasons for the observation that "a comparison between the orthodox model and the conditions which...are common to all developing countries shows that it is utterly inapplicable to them and that the obsessions to which it gives rise are indeed extremely dangerous." 26

Perroux describes, in an extensive list of characteristics for the orthodox model, the assumptions and limitations of that model. He then points out that, in direct conflict with the requirements and limitations of the model, a sound strategy for developing countries calls for changes in the historical forces which are operating. Such a strategy requires a thorough restructuring of the economy, it extends through irreversible time and it presupposes a shift in the power relations within the economy. "In short", he says, "the (orthodox) model depicts a pure market situation with perfect competition, using mechanical analogies; it is diametrically opposed to the conditions common to the developing countries, (those conditions) which can emerge from the limitations of their status only through the combined efforts of the elites and the peoples (in order) to change their immediate and more remote environment. "27

\section{ECONOMIC GROWTH}

Contemporary concern for economic growth is directly traceable to the central concern of the classicists beginning with Adam Smith. For the classicists, national output, and therefore growth in national output was a function of the three factors of production; land, labor and capital. While land was recognized to be fixed in supply, and labor to be a function of the gap between the market wage and the subsistence wage level, it was the formation of capital which was the source of economic growth.

25 Francois Perroux. A New Concent of Development, Cronm Helm, London, 1983. page 185.

26 Perroux, op. cit., page 64 and 65.

27 Perroux, op. cil.. page 65. 
In brief, since economic growth was understood to be a function of saving, and the only factor of production which was capable of saving was represented by capital, the burden in economic growth fell to the owners of capital. From the perspective of the classicists the active element in the process was supplied by the saving from profits and subsequent investment by capitalists.

The contemporary, neoclassical, theory of economic growth differs from earlier efforts (those by Smith, Ricardo, Mill, Malthus, Marx, Schumpeter...) by being both less ambitious and more precise. Commentators on contemporary growth theory cite the Harrod-Domar model (Harrod 1939, Domar 1946) as the prototype post-Keynesian growth model. Although it is recognized to be a relatively simple early formulation of the contemporary model, later growth theory represents departures from the basic theme stated in the Harrod-Domar model.

Explication of the Harrod/Domar model itself can be found in any text dealing with economic growth. ${ }^{28}$ The production function which represents the essence of the Harrod-Domar view of long-run growth relates the generation of total output, $Q$, to the available capital stock, $\mathrm{K}$, via the capital-output ratio, v. The resultant function, $\mathrm{Q}=\mathrm{K} / \mathrm{v}$, assumes that the capital-output ratio is a constant one. Capital, in the original Harrod-Domar model, is the only factor of production, and labor combines with capital in fixed proportions.

Many questions can be and have been raised about the realism of this view of the world. It has, however, served as a key point of departure for more recent neoclassical growth theory as applied both to developed and to underdeveloped nations. The model has undergone many modifications in subsequent years, however. Those include the recognition that there exists more than one factor of production, that income

\footnotetext{
28 Two popular texts cited earlier provide adequate cases in point. Set. for example. Malcolm Gillis, et al. Economics of Development, W.W. Norton and Company, New York. 1983, pages 121-125; or Bruce Herrick and Charles Kindleberger. Economic Develonment. McGraw-Hill Book Company. New York. 1983, pages 28-32.
} 
distribution is not irrelevant to aggregate savings and that technological change is likely to have a significant impact on changes in output. 29

Albert Hirschman, in his influential 1958 treatment of development economics warns that the attempt to apply the economics of growth to the economics of development, particularly to the development of underdeveloped countries, may generate more of a detour than a shortcut. ${ }^{30}$. Specifically, he is referring to the fact that the Harrod-Domar perspective, which represents the origin of contemporary growth theory, grew out of the concern for stagnation of the 1930s and 1940s. Even though the economics of growth of that period represent an advance over the Keynesian model itself, he says, it is a direct descendant of the model.

In concern about growth in the industrial economies, writes Hirschman, the principal focus has been on the savings function, induced versus autonomois investment, and the productivity of capital. The authenticity of these concerns has seemingly been validated through empirical research and, on the whole the concepts appear to be useful for analyzing courses of action regarding growth.

\section{RIGOR VERSUS RELEVANCY}

W. Arthur Lewis, in his post World-War II work on economic growth pointed out that neoclassical 'growth' economists have limited themselves to a very small part of what one might think to be their field of study. As a result, he says, "some of the most elegant work of economic theorists in recent years has been concerned with...economic growth." 31 Beginning by assuming capitalist institutions

\footnotetext{
${ }^{29}$ Regarding the recognition that there exists more than one factor of production, see Solow (1956) and Swan (1956). Representative of concem for distribution of income are Robinson (1956) and Kaldor (1961). For discussion of technological change in the model see Solow (1957) and Kaldor (1957).

30 Albert O. Hirschman. The Strategy of Economic Development. Yale University Press. New Haven, 1958, 29-33.

31 w. Arhur Lewis. The Theory of Economic Growth, London, George Allen and Unwin, Ldd, 1955. p. 13ff
} 
and habits, says Lewis, these economists built mathematical models which oscillate or rise toward a limit. Coefficients and relations between parameters (propensity to save, birth rates or determinants of investment decisions) are assumed and the results follow accordingly. Such models, he insisted, sacrifice potential effectiveness for precision and elegance.

Statistical inquiry based on these models, Lewis points out, has been in search of consistency within the model rather than of questions regarding the appropriateness of the model. The result, he says, is an indispensable tool for short-term analysis. If, on the other hand, "we are concerned with long term studies of changes in propensities..." we must look beyond the boundaries of contemporary economic theory. 32 In other words, if we are concerned with economic development rather than economic growth, contemporary neoclassical theory has been rendered inadequate as a model.

As though in illustration of Lewis' point, in his roughly contemporary work on the theory of economic growth, J.E. Meade states in the introduction and illustrates throughout, that the neoclassical model is a rigorously limited one which cannot comprehend changes over time. ${ }^{33}$ The basic assumptions, states Meade, include that the economy is closed, that it exhibits perfect competition, and so on for several pages. Versions of the list can be found in any introductory text. This basic description of the growth model highlights, for Meade, the observation that although "We desire to watch this system grow through time," we must "confine ourselves to watching this process of growth on the assumption that the growing system remains in equilibrium." This is growth in its essential form. Structural change is ruled out of the model by definition.

\footnotetext{
32 W. A. Lewis. op. cil.. page 13.

33 J.E. Meads. A Neoclassical Theorv of Economic Growith. London. Unwin University Books, 1961, pages 1-7.
} 
Gerald M. Meier, writing on "Free Trade and Development Economics", dispenses with the problem of a model which appears to be inappropriate. Meier asserts that on the one hand the doctrine is fundamentally unassailable from the standpoint of static efficiency conditions. Yet, he says, the "dynamic and structural problems of poor countries now appear to transcend the criterion of maximizing world production efficiency under static conditions." He also recognizes that the assumptions of the theory appear to be unrealistic for a developing country. Those doubts, however, are readily tossed aside because they are "non-economic objectives". The discussion is to be restricted to "the more serious economic arguments only". 34

Albert Hirschman puts these comments in perspective in a chapter on "Growth Models and Development Processes". 35 He suggests that the use of the Harrod-Domar type model to create a loose notion of the amount of capital which may be used in the growth process is probably of no serious harm. But if the user of the model thinks that the relationships assumed in the model stand as a meaningful description of the development process, the model may well become more of a hindrance than a help in achieving a comprehension of the development process.

Hirschman points out that although the model appears to be quite general, it was developed for use in a growth-type environment where the structure of the developed economy is already present. In the radically different context of the underdeveloped economy it has considerably less relevance. It is inappropriate, therefore, for the economics of development to borrow substantially from the economics of growth. The economics of development, he states, must be based on a model whose abstractions are particular to the process of development.

\footnotetext{
34 Gerald M. Meier. "Free Trade and Development Economics". in Value. Canital and Growth. J.N. Wolfe. ed., Edinburgh, Edinhurgh University Free Press, 1968. p. 385 and 386.

35 Albert O. Hirschman. The Strategy of Economic Develonment. Yale University Press, New Haven, 1958, see especially pages 32 and 33 .
} 
This is an important point for Hirschman. He does not address his disagreement to the growth model as such. Rather, his essential point is that the use of the growth model in a situation which requires the creation of an industrial type of economy from a pre-industrial base is both inadequate and misleading.

\section{GROWTH THROUGH REMOVAL OF OBSTACLES}

During the post-World War II period the neoclassical growth theory, developed to illuminate perceived problems of stagnation in industrial countries, became the accepted model for economic development for underdeveloped countries. This application, as was suggested by Hirschman, was quite different from that for which it was designed.

Michael Todaro describes this "traditional (neoclassical growth) paradigm" as one which is based on the neoclassical view of the world where change is gradual, equilibrating and non-disruptive. ${ }^{36}$ He cites the plethora of single and dual sector models which followed introduction of the original Harrod-Domar model. ${ }^{37}$ These models, he points out, tended to focus on optimal savings rates under the assumption that the prime constraint on economic increase is capital. Most attempts to apply the neoclassical growth theory to problems of third world development failed to take account of the unique institutional and structural nature of third world societies.

As development tools, then, says Todaro, these models thus were rendered "inappropriate and irrelevant". Writing to discuss the apparent failure of third world development efforts since World War II, he says that "specifically, the orthodox development models could not adequately deal with the ubiquitous phenomena of rising

\footnotetext{
36 Michael Todaro. "Curnent Lssues in Economic Developmenl", in Econnmic Pursnectives, Maurice Ballabon, ed., New York, Harwood Academic Publishers. 1979. 225.

37 Those include Lewis (1954), Chenery (1961), Jorgenson (1961). Kaldor-Mirlees (1962), and so on.
} 
unemployment, growing (income) inequality and deepening rural poverty which seemed to pervade the third-world development efforts. "38 These were, and for the most part still are, highly fragmented economies characterized more by disequilibrium than by equilibrium relationships.

That such concerns regarding third world development efforts are still simply ignored by contemporary orthodox theorists is illustrated in another of the products of the Harvard Institute for International Development. The 1991 publication, Reforming Economic Systems in Developing Countries, contains fifteen articles by twenty five authors. ${ }^{39}$ Almost all are associates of the Institute and all are economists who are well placed professors, research associates and advisors to third world governments.

In the introduction, Perkins and Roemer, the editors, state that "The dominant vision of the past decade and more has been rooted in powerful propositions of neoclassical economics: the core of economic reform efforts should be devoted to achieving development through competitive markets. "40 The succeeding five hundred pages are focused on illustrating that point from a variety of perspectives.

Dwight Perkins, in the lead article, observes that the industrial nations establish the frontiers for the world economy, and that growth in those nations is determined by the rate of capital formation. ${ }^{41} \mathrm{He}$ then cites two levels of "follower nations". The first are those who manage to overcome sufficient barriers to growth that the rate of savings and capital formation is high enough to generate increases of 6 to 8 percent in GNP per capita. The second are those nations who have not overcome enough of the

\footnotetext{
38 Todaro, op.cil.. p. 226.

39 Perkins. Dwight H. and Michael Roemer. Editors. Reforming Economic Svslems in Develoning Countries. Cambridge. Harvard University Press. 1991.

40 Perkins and Roemer, op. cit.. p. 1.

41 Perkins and Roemer, op. cit., p. 29.
} 
obstacles to growth to take full advantage of being in a "follower" relationship to the industrial economies.

The third, and lowest, economic level for the lesser developed nations is that characterized by nations which have not yet entered into a period of economic growth. These nations are in a stagnant relationship to the industrial economies due to a thorough failure to remove the obstacles to growth. They have demonstrated an inability to raise capital formation above a replacement level and to use productive inputs effectively.

Perkins describes a current Harrod-Domar type model in which the rate of growth is a function of the increase of capital and of its relationship to labor. ${ }^{42}$ It is used to describe a World Bank study of sixty-eight developing nations in which the conclusion drawn is that the factor inputs (labor and capital) account for a very small part of the growth rate of GNP. The largest part is accounted for by the "productivity residual". Therefore, he concludes, it is productivity growth which a developing country must seek. That is accomplished by removing the barriers to a well functioning market system.

Michael Roemer opens the next article in the collection by citing the orthodox argument that "the seeds of today's economic problems (in the developing nations) were sown in the mid- to late 1970 s when oil prices soared, prices of primary commodities first rose, then plummeted... inflation... interest rates..." 43 That is, it was external impacts, not internal structure which accounted for the economic tragedies of the 1980s. What is required in order to deal with the economic problems which resulted from the external impacts is economic reform.

\footnotetext{
42 Perkins and Romer. op. cit., p. 30-33.

43 Perkins and Ruenter. op. cit.. p. 56 and 57.
} 
Roemer makes it quite clear that since the neoclassical argument is based in the paradigm of competitive markets, and since the less developed nations deviate dramatically from the "idealized (neoclassical) model", economic reform requires that corrections for the market failures be prescribed and carried out. ${ }^{44}$ In his argument for the removal of obstacles, Roemer points out that when time is added to the ideal competitive market model, it can be mathematically demonstrated that income growth will be maximized. The reform which is required, in other words, consists of removing obstacles to the ready functioning of the market in order that the underdeveloped economy may achieve growth, in emulation of the elegant mathematical model to which $\mathrm{W}$. Arthur Lewis refers in the Theory of Economic Growth.

Albert Hirschman describes obstacles as "forces corroding development". $45 \mathrm{He}$ is referring not to entities but to a kind of compulsion, a dynamic energy. These forces tend to cause "abortive development,...stagnation, and decay of ventures that looked hopeful at first." Aside from the structure of things in the underdeveloped nation prior to attempts at development, he says, there are forces which are hostile to development that the development process itself brings into being.

Hirschman concludes the section on forces corroding development by suggesting that development be approached with something like a learning model. This would be a dynamic model, that is, not one which is self contained and predetermined. "We do not propose a rigid model of economic development," he says, but rather, "a theory of development strategy."46

\footnotetext{
44 Perkins and Roemer. op. cit.. p. 57 and 58.

45. Alber O. Hirschman. The Stralegy of Economic Develonment. Yale Universily Press. New Haven. 1958. p. 44.

46. Hirschman, op.cit.. p.49. In the 1986 discussion of his experience as a World Banl: sponsored advisor to an underdeveloped Latin American nation in the 1950s. Hirschman states that "The point (of much of his disagreenent with received
} 


\section{Limits of the Theory}

As suggested above by J.E. Meade, the neoclassical model is intentionally limited to comprehending an economy as increasing over time in equilibrium, without accounting for a change in the economic structure itself. ${ }^{47}$ To some extent that is a function of what both Lewis and Hirschman describe as the elegant mathematical structure which has come to contain and to constrain the theory. ${ }^{48}$ But it is a result of the historic development and the intent of the theory as well.

According to the theory, 'market forces' account for the development of the industrialized nations of the turn of the century. The considerable guidance, intervention and alignment of the developing nations of the 18 th through the 20th centuries is generally overlooked or assumed. Evidence for the assumption appears in the writings of those theorists and textbook writers who merely mention the role of the elite in the industrialization process in passing. Walt Rostow, for example is well known for having mentioned throughout his work on The Stages of Economic Growth that the role of the elite as determiners of the process is critical. ${ }^{49}$ Textbook writers also typically make broad mention of the importance of the leadership. 50

The neoclassical theory of growth, then, looks at the growth process as one which can be understood through comparison of two or more static states of an economy. It also looks at the particular structures of the developed economy as given.

policy) was to get away froin the excessive simplicities of certain growth models." See. "A Dissenter's Confession", in Rival Views of Market Snciety. Viking Press. New York. 1986. p. 24.

47 See. for example. J. E. Meade. op. cil.. page 3.

48 W. Arthur Lewis. op. cit.. page 13. and Alhen O. Hirschunan. op. cit.. page 32 and 33.

49 Walt W. Rostow. The Stages of Economic Gmwth: A Non-Communisl Manifesto. Cambridge University Press. Cambridge. 1969. Antong many other such references throughout the book see pages 8.39 and 51.

50 Herrick and Kindleberger, op. cit.. make mention of the importance of the role of the leadership on page 226. for example, among their conments on the role of governments and other organizations in the growth process. 
Such structures are merely obscured by the pre-developed state of the underdeveloped economy, and time is recognized within the growth process as that unaccountable period between two states of the economy.

Thus, the taking into account of the critically important dynamic element in the transformation of the economy from underdeveloped to industrialized is left to what Rostow, for example, refers to as "the role of a leading elite in economic growth". 51 That crucial element of the process is passed over lightly by neoclassical theorists as outside the realm of economics.

The atemporal and perspectivally constrained nature of the neoclassical growth model is addressed by Albert Hirschman's suggestion that development should be approached with a "learning model", not one which is self contained and predetermined. 52 Such an approach suggests opening the process to the incorporation of both historic (contextual) time, and time internal to the process. This is a concept of development which is responsive to both the internal circumstances and the external influences on the developing nation.

There is a set of key issues which form consistent themes through the commentary of the entire range of writers, from those on the orthodox (the growth) end to those on the strictly development end of the issue. Those include:

- The necessary role of the elite.

- The involvement of the entire population in the process.

- $\quad$ The need to reach beyond the narrow range of the economics discipline in order to comprehend economic development.

- The inadequacy of the static model to portray a dynamic event.

- $\quad$ The inappropriateness of the rigorous assumptions of the model.

- The inappropriateness of a growth model for what is a development process.

- $\quad$ The need to guide the process (via policy) rather than presumably leaving it to the market.

51 W. W. Rostow, op. cit., page 51.

52 Albert O. Hirschman, op. cit.. page 49. 
In general, this study recognizes the need to move toward the modeling of the organized complexity implied by reference to the broad domain of economic development. Such a conceptualization must represent a perspective which is essentially interdisciplinary. It must recognize the close interaction of the nation's economic production per se with the realms of health, education, science, technology and politics. Any development model must recognize the complexity, and it must at the same time encourage specificity in application. That is, it must encourage adaptation of the analysis to the cultures and institutions which are under investigation.

In this study in particular, the definition by Simon Kuznets of modern economic growth will be accepted as a valid description of the current conception of the highest attainable form of development. That is to recognize that while economic development is a process which must continue from one identifiable stage to another, modern economic growth represents a clearly definable present stage in that process. Modern economic growth then, implies the accomplishment of a sustained increase in economic output based on a dynamic process of structural change which necessarily incorporates a wide range of social, political and economic aspects of the nation. 


\section{CHAPTER III}

\section{THE NEOCLASSICAL THEORY EXPANDED FOR ECONOMIC DEVELOPMENT}

\section{EXPANDED PERSPECTIVES FOR DEVELOPMENT}

Since the middle of the century a great deal has been offered by theorists in economics to expand the concept from neoclassical economic growth toward the more comprehensive and complex economic development. Key contributors include Kenneth Boulding, Albert O. Hirschman, Jan S. Hogendorn, W. Arthur Lewis, Hla Myint, Gunnar Myrdal, Francois Perroux, Walt W. Rostow and Simon Kuznets. All have indicated concern for the injurious limitations on the effort which are imposed by using exclusively the neoclassical growth model.

The concerns of those economists start with the application of the insights of the model as though they were adequately inclusive of the reality of development. Rather, the situation of development is too complex to be adequately portrayed by such a simplistic model, and it is too dynamic to be appropriately represented as a static process. Further, the model was generated in an historical and cultural environment which was dramatically different from those of the underdeveloped nations of the late twentieth century, and it was created to portray problems of growth in a developed economy, not problems of structural transformation in a developing economy.

Those writing about the need to expand the concept of economic development have all indicated in one way or another that the process must be understood as both dynamic and comprehensive. Therefore the picture of the process must be inclusive beyond the strictly economic. Referring back to W. Arthur Lewis as a case in 
point, though he is among the least adventurous of those on the list with respect to willingness to range away from the neoclassical model itself, the list of concerns beyond the strictly economic is extensive. It would include human behavior in the specific cultural environment, the development of the institutions, the accumulation of knowledge within the population, a good understanding of the characteristics of the population and of the resources available and of the capacity of the leadership to make the critical decisions necessary for healthy promotion of development. Using Lewis' terms, this would draw on fields which economists have tended to leave "to sociologists, to historians, to students of beliefs, to biologists, to geographers...".

All are insistent as well that the structural changes which are inevitable in economic development must be understood by the decisionmaker. That means not relying solely on the static neoclassical model, though it does not mean simply replacing it with another particular model. The consensus is that it is necessary to evaluate a development project using the insights of the neoclassical model in the context of a much broader comprehension of the process.

Exclusive dependence on mathematical modeling as the language of choice by neoclassicists in the last few decades, has also drawn many cautionary comments. Hirschman, Boulding and others have suggested that there is nothing wrong with the use of the mathematical tools of the neoclassical model as such. The danger appears in the use of such tools to model a development effort in just the same way that it does in operations research or any other use of mathematics to model reality. Users of the models have to assume the assumptions. They forget, that is, the considerable simplifications made in creating the model. Thus the results of the mathematical modeling effort are likely to be taken as more realistic than is appropriate. The general conclusions of such a model are often simply confused with reality. Neoclassicists seem to be especially subject to this problem. Much of the talk of the need to 'remove 
the obstacles' to free markets reflects this confusion. The literature is full of recommendations to underdeveloped-nation policymakers to strive to make the economy look like the neoclassical model. A comment by Michael Roemer in his 1991 text is an excellent case in point. ${ }^{1}$ He specifically states that since the mathematical model demonstrates that income growth will be maximized under competitive market conditions, the developing nation must emulate that model.

Contrary to such a suggestion, most of the theorists cited caution against excessive dependence on the market in place of decisionmaking by policymakers. What they propose comes to a guided use of the market in the development environment. This took the form in the case of Taiwan, for example, of leadership in the search for and development of comparative advantage within the population as a whole.

Two other consistent themes to be found among those concerned for the expanded context is the importance of incorporating the entire population in the development effort, and the need to incorporate and use knowledge in the process. Lewis devotes a full chapter to the importance of knowledge in the process. For him the 'accumulation of knowledge' is equal to the accumulation of capital as determiners of development. ${ }^{2}$ Both of these are central themes in the work of Simon Kuznets as well, whose work will enter into consideration in the next section of this chapter.

\footnotetext{
${ }^{1}$ Michael Roemer, on pages 57-59 in his discussion of "Macroeconomic Ruform in Developing Countries", in Dwight Perkins and Michael Roemer, editors, Reforming Econumic Svstemes in Develoning Countries. Cambridge. Harvard University Press, 1991. illustrates the need for enution when he states that the developing country must strive to emulate the ideal competitive market model because it can be mathematically demonstrated that income growth will be maximized in the ideal market environment. See also the discussion in chapter one above of the economic growth texts such as those of Malcolm Gilles, et al, and Herrick and Kindelberger, and the discourse on statt-of-the-an policymaking in chapter iwo. A considerable list of economic advisors and teachers of policymaking for underdeveloped nations advise complete faith in the market.

2 W. Arhur Lewis. Theory of Economic Growth. London. George Allen and Unwin Lid.. 1955. pages 164-200.
} 
All of the writers who are concerned with expanding the theory to more accurately represent the development effort specifically advise the avoidance of simple application of the neoclassical growth model with its accompanying assumptions and pre-judgmental solutions. Generally the development process is recognized to be one of exploration and invention rather than application of what Hirschman referred to as a synthetic development plan.

\section{ADAPTING THE NEOCLASSICAL}

Simon Kuznets' concept of modern economic growth has been a guiding perspective for many years in the development effort in Taiwan. At a 1982 conference on The Experiences and Lessons of Economic Development in Taiwan Kuznets was invited as a keynote speaker and his work on modern economic growth was cited often in the papers and proceedings. In one of the papers John $\mathrm{C}$. H. Fei describes the development process in terms of modern economic growth and compares the expectations of Kuznets' concepts to those of the traditional and ideological values which supported the development effort. ${ }^{3}$

Fei argues that since an essential element of modern economic growth is the expectation of structural change, it is important for the leadership in the developing nation to understand whether or not the traditional values and ideology of the agrarian society from which the modern economy will emerge are supportive of or resistant to the process. Kuznets describes such a developed economy as being characterized by a secular, egalitarian and nationalist qualities. ${ }^{4}$ All of those qualities, Fei feels, are

\footnotetext{
3 John C. H. Fei, "Ideology of Economic Development in Taiwan", in The Experiences and Lesssons of Econnmic Develonment in Taiwan, Kwoh-ting Li and Tzong-shian Yu Editors, Taipei, Academia Sinica. 1982.

4 Simon Kuznets. Modem Economic Growth: Rate. Struclure and Snread. New Haven. Yale University Press, 1966. See especially chapter 1. "The General Framework".
} 
supported by both traditional Chinese values and the economic principles of development of Dr. Sun Yat Sen with which the mainland Chinese leadership arrived in Taiwan in the 1940s. He observes, therefore, that "we may conclude that traditional Chinese ideologies and values are perfectly compatible with the requirements of modern growth when gauged in terms of (the qualities cited by Simon Kuznets) egalitarianism, secularism and nationalism." 5

The difficulty, says Fei, is that, unlike the circumstances in the traditional agricultural society which preceeds the developing economy and the economically developed state which succeeds it, during the period of transition the rules of growth are in constant flux. During that transition period the set of agreed upon economic rules "are neither stable nor unified". "A new set of rules of growth must be found gradually during the development process." New institutions must be developed and perfected and an officially proclaimed ideology, "a visionary theory", must be put forth by the leadership as a means of organizing the energy of the population toward the emerging 'new rules'. 6

Fei describes the policy process in the preceeding years of development as necessarily "non-doctrinaire, because problems change during the transition process." 7 He suggests that the leadership in Taiwan was non-doctrinaire but well ensconced in the set of principles derived from the early leadership of Dr. Sun and in the traditional Chinese values which supported the qualities of modern economic growth. It is apparent, on the other hand, that the 'unexpanded' view of the neoclassicists is extremely doctrinaire. This is especially clear in terms of the definition given by Fei,

\footnotetext{
5 John C. H. Fei, op. cit., page 89.

6 John C. H. Fei, op. sit.. pages 92-93.

7 John C. H. Fsi. up. vil.. page 95.
} 
that by doctrinaire he means "a visionary, political, unpractical theorist, or one who theorizes without paying sufficient heed to practical considerations."

Taiwan's Kuo-Min-Tang party, on the other hand, operating within the context of a thorough respect for the value of markets for allocation decisions, guided the economy through two major phases of policy focus and many lesser ones. Beginning in the 1950s with what is generally referred to as the 'import substitution' phase characterized by unemployment, receipt of foreign aid, foreign exchange shortfalls and a push for food self sufficiency - the policy guidance evolved into the 'external orientation' phase in the mid-1960s - characterized by increasing wage rates and labor shortages. Fei draws his article toward a conclusion with the comment that he would "argue that the spectacular success of Taiwan during the last thirty years was due primarily to the official camp's problemsolving orientation and pragmatic approach that led to the adoption of policies that unleashed the full creative energies of the Chinese in Taiwan, within the context of a free market economy. " 8

In keeping with the concerns and suggestions of the several authors discussed earlier, this study will emphasize development-type indicators which are also in keeping with the concept of modern economic growth of Simon Kuznets. The indicators will be weighed and evaluated in a diagnostic sort of context, in keeping with the approach to policy taken by the Taiwanese leadership in the decades since the 1950 s. As will be discussed below in chapter four, the availability of the data for the Central American nations limits the type of indicator which can be used. But the intent is to approximate the key areas of concern in development toward modern economic growth as described by Kuznets.

\footnotetext{
8 John C. H. Fei, op. vil.. page 98.
} 
"The basic feature of modern economic growth", says Kuznets in virtually everything he has written on the subject, "is the rise in per capita or per worker product". This increase is entirely dependent upon "the capacity of the population to respond to changing economic opportunities through education, through migration, and through shifts in both demographic patterns and in sets of values toward greater consonance with the opportunities and requirements associated with modern technology." 9 It is necessary, in other words, to engineer the development process to require the development of the entire national population together with the financial and technological aspects. Furthermore, says Kuznets, the importance of the state in the development process is in the service it performs "in organizing the human element more effectively for realizing the economic growth potential. The sovereign state unit (is) of critical importance as the formulator of the rules under which economic activity (is) to be carried on; as a referee in the variety of institutional innovations needed to channel economic growth effectively; as the protector of social consensus needed...and as provider of infrastructure that is needed by all but may have been beyond the specific interest of any one group." 10

\section{TRANSFORMATIONS CHARACTERISTIC OF MODERN ECONOMIC GROWTH}

Kuznets describes the acceleration of economic activity in development as associated with a number of other economic and social processes. The "driving forces", he suggests, include three key elements. The first two are, "a high rate of accumulation of useful knowledge and of technical innovations derived from it, and shifts in the production structure of the economy, (particularly) in the shares of the

\footnotetext{
${ }^{9}$ Simon Kuznets. Economic Develonment, the Family, and Income Distrilumlion. Cambridge. Cambridge University Press, 1989, pages 68 and 69.

10 Simon Kuznets, op. cil.. page 70.
} 
production sectors in output, labor and capital. ...The third major strand in the unfolding of modern economic growth is the complex of functions and influences associated with the national sovereign state. 11

In all of his earlier writings Kuznets described the exhaustive statistical studies of the process of development toward modern economic growth on which his life's work was based. From those studies he generated a detailed set of indicators which he concluded to be representative of the process. Those indicators, which were found to be strongly consistent with the development experience in both South Korea and Taiwan, took the following form.

First presented as a theory in an extensive article written in 1955, the model was presented in its full form in 1966 in the book cited above, Modern Economic Growth: Rate Structure and Spread. ${ }^{12}$ Aside from the anticipated rise in population growth, the major transformations to be expected include an increase in both total and per capita product coupled with an augmentation in the rate of increase of efficiency of production. Necessarily linked to that increase is the change in structure within the three major sectors, agriculture, industry and services. The share of agriculture in the total product can be expected to decline, while that of industry would increase rapidly. Services, on the other hand, which include banking, public agencies, and so on, were found to increase slowly in the total mix. ${ }^{13}$

Kuznets found that an important aspect of both the expansion and the shift in structure is that it represents a sustained change. This sets forth one of the many significant distinctions between the ENICs and the CANs. He says that "By a sustained

11 Simon Kuznets, op. cil.. "Driving Forees Of economic Growth: What Can We Leam From History?", page 8.

12 The 1955 article. "Towards a Theory of Economic Growth", appeared in the book. National Policy for Economic Welfare at Home and Abmond. edited by Robert Lekachman. New York. Russell and Russull. 1961. Simon Kuznets, Moderm Economic Gmunh: Rale Structure and Spread, New Haven. Yale University Press, 1966.

${ }^{13}$ Simon Kuznets, op.cit. The first three chapters deal with these issues. In particular, see pages 34 through 160. 
increase we mean a rise of such magnitude that it is not overshadowed by short term fluctuations. And by a sustained trend in structure, e.g. a shift toward nonagricultural sectors, we mean one in which the rise in the share of nonagricultural activities in output (or in labor force) is not overshadowed by short term fluctuations in the shares." 14 He goes on to point out that although it is statistically difficult to establish a firm measure of what is meant by short term fluctuations, "a cumulative increase in total or per capita product of a few percentage points even over a long period, say thirty years, can hardly be considered sustained and taken as a measure of secular rise unless there is substantive evidence that a cyclical decline in the foreseeable future will not reduce it to insignificant dimensions. " 15 The data in chapter 8 will be seen to serve strikingly as illustrations of both sides of the question. While the ENICs fit the description of sustained development toward modern economic growth, the CANs, for the most part, illustrate the failure to generate that sustained change in structure or the sustained increase in per capita output.

Another important transformation in the process relates to the distribution of product and the distribution of income in the economy. Since the data on income distribution for the CANs is all but nonexistant, and that on distribution of product is minimal, undependable and inconsistent, it is not possible to compare the two groups of nations on these points. The Kuznetsian expectations, however, include an increase in the share of labor in national income and a decrease in the share of national income going to holders of assets. These changes reflect what Kuznets refers to as the phenomenon of "income mobility". Groups previously low on the income scale are rising while those previously high on the scale are falling. 16

\footnotetext{
14 Simon Kuznets, op. cit., page 26.

15 Simon Kuznets, op. vil.

16 Simon Kuznets, op. vit.. pages 195 w 220.
} 
Kuznets found that the changes in income while a nation moves toward modern economic growth can be expected to give rise to an increasing equality in its distribution. This projection was tested and the conclusions were presented in a World Bank publication in 1979 in which Taiwan was concluded to have taken "an approach to growth with equity." 17

There are also transformations to be expected in the patterns of product use. Here Kuznets has looked at the use of output broadly distinguished between private consumption, government consumption and domestic capital formation. Though the distinctions give rise to complex internal questions of definition, the statistics generated clear patterns on the aggregate level. It was determined that during the transition period the share of government consumption can be expected to increase by several percentage points of GDP, private consumption is likely to decrease as a percentage of GDP, and gross domestic investment should increase during the period of development. It should be clear that while private consumption will decrease as a fraction of GDP, the same figure per capita is expected to increase substantially. This is a function of the increasing product per capita, and it can be expected to increase in spite of the larger part of GDP devoted to investment and to increased government consumption.

Kuznets, in connection with others in the context of World Bank efforts, has published many more detailed studies of the changes in structure to be expected of a developing nation. 18 While these relate to specific policy questions for a nation undergoing the transition process, they are related to the broad question of growth versus development in a much more complex way, and in a much more country specific way than is appropriate to enter into in this study. In this study, indicators

17 John C. H. Fei, Gustav Ranis and Shirley W. Y. Kuo, Growth with Equity: The Taiwan Case. New York, Oxford University Press (Published for the World Bank), 1979.

18 Besides the Kuznets works ciled above, the Fei, Ranis and Kuo book explores income data in detail, and the several works by Hollis Chenery and others explore the issue through several ways of temporally slicing and manipulating the data. 
based in the broad catagories will be used in the effort to demonstrate whether or not the economies in question established a record of transition development which is consistent with the model of modern economic growth.

In the 1990 edition of his The Stages of Economic Growth, W.W. Rostow discussed the definitional aspects of the process of development in a section entitled "Reflections On The Debate As Of 1990". He describes his concept of stages as directly comparable to Kuznets' transition to modern economic growth. ${ }^{19}$ In doing so he offers a definition and a description of the process which highlights the character of development.

The issue for Rostow is focused in the question: "Should one define modern economic growth in terms of GNP per capita, or in terms of the degree to which the pool of then-existing technology had been efficiently absorbed in a given society?"20 The latter criterion, he points out, requires disaggregation to the level of sectors within the economy, and to the point where the introduction of innovations can be accounted for.

Neoclassical growth modelers, Rostow states, have been committed to a pattern of concepts that concealed technological change in a highly aggregated black box. Aggregate growth, therefore, is included by Rostow in the expectations for development as a necessary but insufficient aspect of the process. The activities within the various sectors interact with the growth phenomenon in a wide variety of ways, some waxing and others waning, but on the whole, in agreement with Kuznets, Rostow

\footnotetext{
19 Walt W. Rostow. The Stages of Economic Growth: A Non-Communist Mannifesto. Third Edition. Cambridge. Cambridge University Press. 1990. page 242-258.

20 Wall W. Rostow. op. cil.. page 242.
} 
describes "the take-off as the period when a society begins to yield a more or less regular increase in output per capita." 21

At the same time, however, the 'take-off' and the 'drive to maturity' require that the society absorb new production functions in ways which generate the spreading effects on which the development of the economy depends. This preparation includes attributes such as a "build-up of transport capacity", a "quantum of literate and technically trained personnel" and other "overhead capital".

In keeping with similar comments by Kuznets, Fei, Ranis and others, a key distinguishing feature for Rostow is the "changes in the rules of behavior". By this he refers to an elite which, besides launching the leading sectors, will follow up in the secondary and tertiary sectors, creating links "backward and laterally to the leading sectors."

But in the final analysis, for Rostow's "stage of economic maturity", similar to Kuznets' arrival at modern economic growth, it is "the period when a society has effectively applied the range of modern technology to the bulk of its resources which distinguishes the stage. ${ }^{22}$ This stage is reached through a succession of stages which represents an economic building process in which earlier, technologically more primitive forms of industrialization are replaced by technologically more sophisticated ones.

Historically, the particular forms characterizing the process have varied with the resource endowments, the historical period, and the nature of the social environment. For the United States, Germany and France, Rostow cites the railroad as the takeoff technology, with the subsequent phase concentrated on the development of "post-

21 Walt W. Rostow. op. cit., page 245, quoled from W.W. Rostow (ed.). The Economics of Take-off Into Suslained Growth. London. Macmillan, 1963, pages xxiv-xxvi.

22 Walt W. Rostow. The Stages of Economic Gmwth: A Non-Communist Mannifesto. Canbridge. Cambridge University Press, 1960, page 59. 
railway technology", central of which is the elaboration on steel. For Sweden the "take-off" industry was timber export, followed by a shift into milled lumber, mining and hydro-electric power sources in the latter nineteenth century. 23

The stages described by Rostow represents a constant transformation of the economy. The transformation is based on exploitation of some capacity of the nation which is treated as a competitive advantage. The initial capacity provides the basis for the initiation of the structural change which culminates in the absorption of the thencurrent state of technology. The interim structural change, says Rostow, again in keeping with the criteria for modern economic growth described by Kuznets, is notable through two important changes in the character of the nation. The first is that there are large scale changes in the real wage, the skills, and the attitudes of the working force. The nature of work is changed for the majority of the nation. The second is that the nature of the leadership changes. From the early, relatively adventuresome, pioneers, the leadership becomes transformed into something more approximating efficient, professional managers.

Rostow describes economic development as a non-linear, dynamic process which is driven by the changes which characterize it. Prime among these are changes in population, in resource availability, in investment and in technology. Like other non-linear, dynamic systems, such as the growth of a biological organism, the developing economy can be expected to be in perpetual disequilibrium. 24 "Economies exhibit something akin to structural 'phase transitions' as they undergo the creativedestructive process of absorbing new technologies. "25 The disequilibrium, however, is

\footnotetext{
23 Walt W. Rostow. op. cit., pages 70-72.

24 Walt W. Rostow. The Stages of Economic Growth: A Non-Communist Maanifesto. Third Edition, Cambridge. Cambridge University Press, 1990, page 251.

25 Wait w. Rostow. op. cit. page 253.
} 
subject to guidance through indirect forces such as price mechanisms, as well as through the direct and intentional techniques of government policy.

As a result of the fact that economic development is a complex, interactive process which is characterized by disequalibrium, says Rostow, economic development processes cannot be expected to follow a particular pattern. They do, however, "yield recognizable patterns capable of cross-comparison", even though the initial conditions are never the same from one country to another, nor is the historical period, nor many other of the parameters of the process. What is important for Rostow is that we "can detect elements of universality in the performance of economies" in the development process. 26

Those elements of universality, which are described in the preceeding paragraphs for Rostow, are consistent with those found by Simon Kuznets in his statistical studies. Besides the requirement of a leadership which has the will to promote the change in structure, the labor force as well becomes transformed through education and through changes in the real wage. As with the achievement of modern economic growth for Kuznets, the stage of 'maturity' for Rostọw is marked by the effective application of modern technology to the resources available to the economy.

26 Walt W. Rostow. op. cit.. pages 252-255. 


\section{CHAPTER IV}

\section{THE METHOD}

\section{DEVELOPMENT DATA AND THE ROLE OF POLICY IN DEVELOPMENT}

The literature reviewed in the previous chapters make it clear that the role of the leadership in national economic development is crucial. Because a sustained increase in total output requires an underdeveloped nation to undertake structural transformation, government policy must encourage or even compel a transformation in economic production.

The policy which results from the intention to transform the economy is expected to give rise to a pattern of change in the economy which is consistent with the results of the statistical studies by Simon Kuznets which were described in the previous chapters. Kuznets found that historically, among the industrialized nations of the world, a consistent set of patterns emerged in the economic data.

Kuznets emphasized that the data must be examined over an extended period of at least two or three decades. For some of the earlier developing nations the process involved up to a century. As the level of science and technology on the global level increased, however, the period of development decreased. 1

GDP was found to undergo a sustained increase over the development period of at least 2 to 3 percent per year, and GDP per capita underwent a sustained increase of 1.5 to 2 percent per year. Two of the three major economic sectors also underwent profound changes. In essence, agriculture and industry reverse their importance in the

\footnotetext{
1 The statistical studies and the conclusions with respett to modem economic growth are described in detail in Simon Kuznets, Modem Economie Growth: Rale Structune and Spread. New Haven. Yale Universily Press, 1966.
} 
makeup of total output. While agriculture tended to start the period of development as at least 40 percent of GDP, it fell to 10 to 20 percent in all of the nations which achieved modern economic growth. At the same time, industry started at 20 percent or less, and climbed to 40 or 50 percent of total production. For services as a percentage of GDP, on the other hand, the statistics showed no marked trend. Although the makeup of the services category changed, for services as a part of total output there was little change.

In terms of the use of total output, private consumption per capita was found to have increased to 3 or 4 times the initial level, while private consumption as a percentage of total output decreased from over 80 percent to 60 or 65 percent of GDP in spite of the population increase which accompanied the process. Domestic savings increased, at the same time, from less than 10 percent of GDP to between 15 and 20 percent.

Gross Domestic Investment as a percentage of GDP was found to increase from approximately 10 percent to something between 20 and 30 percent, generally over 25 percent. At the same time Gross Domestic Investment per capita increased consistently, the specific amount depending upon the rate of population increase.

As indicated in the previous chapter, Kuznets found that education was a key ingredient in the development process. During the period of development large scale investment was made in education, and the entire population of the developing nation was involved. The expectation of universal literacy, therefore, can serve as a basic but dependable measure of the level of engagement in education for the developing nation.

A highly generalized pattern of the data found to be consistent among the statistical findings by Kuznets is presented in Figure la below. Although the horizontal axis represents the passage of time, three decades, in the panel below, the vertical axis is simply an anchor for the indicators. The panel is intended to illustrate the relative 
increase, decrease, or lack of change in the indicators over time. The indicators are arranged in the panel from the top down in the order discussed above. No hierarchic implications should be drawn from the arrangement.

This study is more limited in terms of the indicators available than the same study of a single country might be. In this case it was necessary to limit the indicators to those which are both available and consistent among the Central American Nations and the two Eastern Newly Industrializing Countries. For a similar study of a single nation it may be possible to collect data for some of the more telling indicators such as income distribution, employment by specific sectors and breakdowns within the sectors.

For this study the decision was made to limit the indicators to those which could be generated from data published primarily by international agencies. The agencies chosen were The World Bank, the International Monetary Fund and the United Nations. That left the further problem, however, that data for Taiwan, The Republic of China, is not published by those agencies. Taiwan has not been a member of the United Nations for 22 years and has never been a member of the World Bank. That meant that it was necessary to resort to data generated and published by Taiwan itself. The first question, whether or not there was data available which could be reconciled with that published by the international agencies, turned out to be answered readily by the fact that Taiwan collects and publishes an elaborate set of data. This is data which is collected for the purpose of guiding the development process. Fot that reason there is data available which readily fits the indicators described by Simon Kuznets as representative of modern economic growth.

For Taiwan there is detailed data available on education and literacy, on income distribution by geographic region and economic sectors, on employment, health, debt, foreign trade and so on. Therefore, reconciling the data of Taiwan to that published by the international agencies was not the limiting factor. The limitation was on the side of 

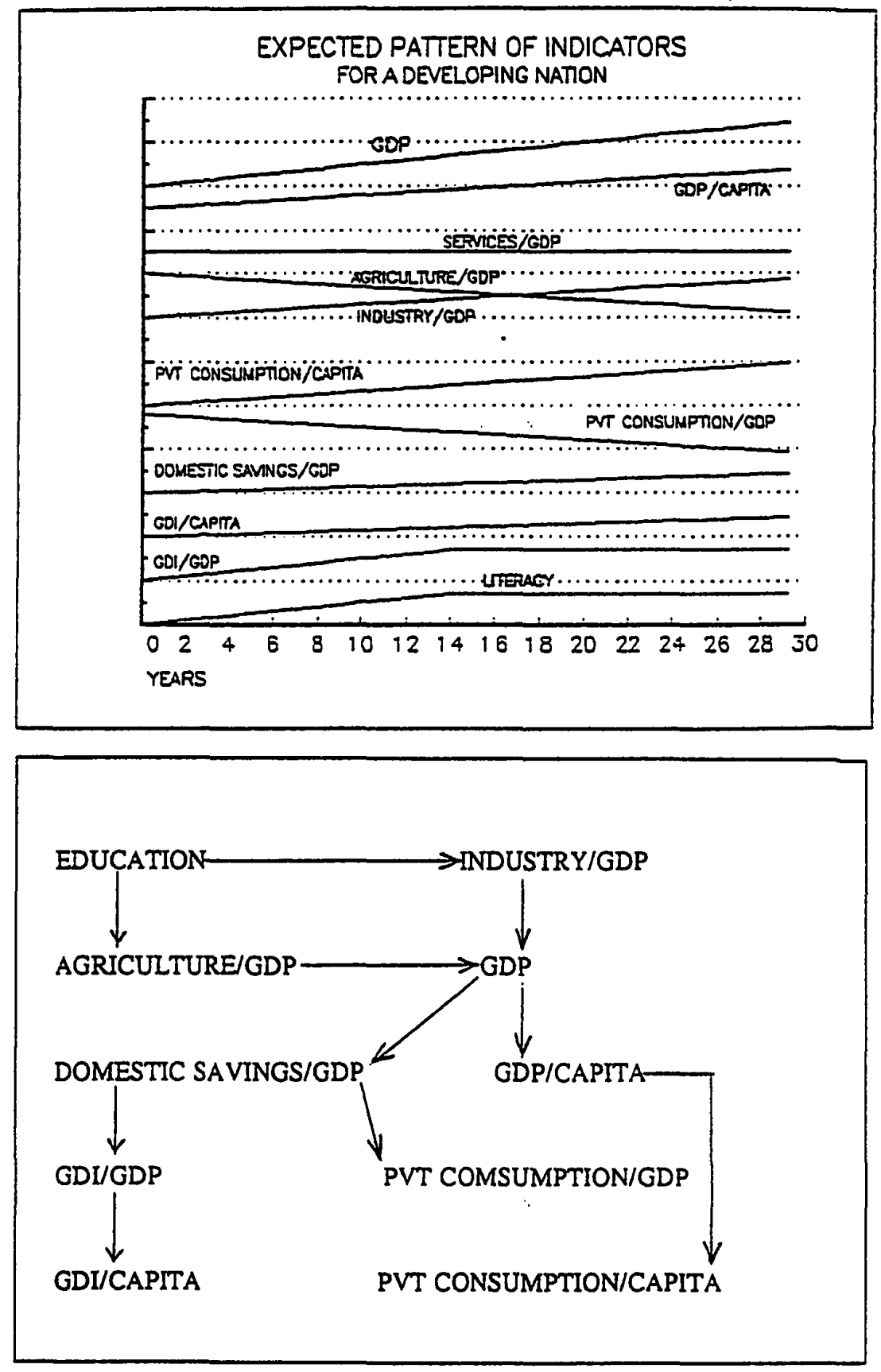

Figure 1. Expected Pattern of Indicators for a Developing Nation (a) and Relational Model of the Development Indicators (b). 
the relatively slender amount of development-related data published for the Central American Nations. ${ }^{2}$

Taken together, the need to incorporate data beyond the economic and the need for locally informed judgement in policy decisions regarding the search for dynamic comparative advantage, result in an approach to development policy which looks considerably like that used in Taiwan since the 1950s by the ruling party, the Kuo Min Tang (KMT). There the general policy direction is typically described in terms of three distinct phases in the period of development toward modern economic growth.

It was with the publication of Simon Kuznets 1966 work, Modern Economic Growth: Rate Structure and Spread, that there emerged something of a theory and language for the process of economic and organizational metamorphosis through which the nation was passing. ${ }^{3}$ John C. H. Fei, in publications since the 1970 s on the economic development of Taiwan, has related the process to Kuznets' studies. ${ }^{4}$ In keeping with the portrayal of the process by Kuznets, he describes the starting point in Taiwan as the agrarian one which is typical of other LDCs as well. Taiwan, like the Central American Nations, started with an economic structure based on the export of primary products and the import of final manufactured goods.

In the 1988 publication cited above, Fei describes a set of successively more complex levels of economic development, each of which depends upon the preceeding one. "So", he says, " the transition growth process can be viewed as a metaporphosis

\footnotetext{
2 See Richard Kibbey, "The Crisis in Central America: Failure of Economic Growth Policy", scheduled to be published in the late fall of 1993 in the International Third World Studies Journal, Volume 5, Number 4, 1993. The issue of the lack of development oriented data among the Central American nations is explored in this article.

${ }^{3}$ Simon Kuznets, Modem Economic Growth: Rale Structure and Spread, New Haven, Yale University Press, 1966.

${ }^{4}$ For example, see Growth With Equity: The Taiwan Case, New York. Oxford University Press (for the World Bank), 1979 and "A Bird's Eye View of Policy Evolution on Taiwan" in K.T. Li. The Evolution of Policy Behind Taiwan's Develonment Success, New Haven, Yale University Press, 1988.
} 
characterized by phases occurring in a reasonably definite sequence." 5 Any economic development effort for an LDC begins with what Fei describes as a set of exogenous factors. The three key groups of factors which affect the transition process are the world economic environment, the particular economic geography of the nation and the cultural and historical background of the nation. It is that unique set of factors for each developing nation which makes government in the process necessary.

Within that set of factors Fei describes the forces which act on the evolution of policy as either objective or subjective with respect to a given development project. The objective forces are those which are given for the policy makers, the economic geography or the conditions of the world economy. The subjective forces include the ideology of the policymakers themselves and the consequences of previous policies. 6

Fei, along with Ranis and others writing on the experience of Taiwan and South Korea, refers to government policy in the development process as the requisite intervention into the functioning of the market process. These policies address specific areas of guidance, such as interest rates or taxes, says Fei, but they also function on the level of specific policy coordination referred to as planning.

These policies are seen, both by Kuznets and by Fei, Ranis and others writing on Taiwan, to have two prime purposes. They serve to promote the development of the economy itself, but they also promote an important sense of national unity through the increase of broad economic welfare. Both, says Kuznets, are necessary to the emergence of modern economic growth.

5 John C. H. Fei, "A Bird's Eye View...", op. cit., page 28.

6 John C. H. Fei, op. cit., page 31 ff. 


\section{THE INDICATORS OF GROWTH VERSUS DEVELOPMENT}

In keeping with Kuznets' findings, both GDP and GDP per Capita have been established for the seven nations as a basic indicator. These are necessary though insufficient indicators. An underdeveloped economy which is not increasing in total output as well as in output per capita is not undergoing the fundamental requirement of transition toward modern economic growth. Furthermore, as described above, the expansion in both GDP and GDP per Capita must be a sustained one in a developing economy. As Kuznets put it, a developing economy in which the increases are overshadowed by interim fluctuations cannot be considered to be undergoing the requisite transition.

The second category of indicators, those which represent the structural change in the economy on an aggregate level, is the three major sectors represented as percentages of GDP. As suggested in part two in this chapter, an economy which is undergoing transition toward modern economic growth will show a replacement of agriculture by industry as a significant aspect of total product. At the same time, while agriculture shows a strong decrease and industry a similarly strong increase, the service sector can be expected to increase, though to a minor extent.

In the third category, use of the increasing output, Kuznets found clear patterns which are to be anticipated in the transition. For the seven nations, data will be found in chapter 8 on private consumption, savings and domestic investment. In a developing economy private consumption is expected to decrease as a fraction of GDP and increase on a per capita basis. Consistent with the decreased consumption, domestic savings should show an increase as a part of GDP, as will domestic investment. Those three 
indicators are illustrated in the next chapters and all three generate suggestive insights with respect to the growth versus development issue in terms of the ENICs and the CANs.

A fourth realm of critical concern which was highlighted by Kuznets for a developing nation is education. It is education which represents both investment in the population of the nation as the critical factor input for a modern economy and the infusion of knowledge and science into the production process as essential to the developing economy. In the 1966 study Kuznets concluded a discussion of the increasing income to labor in the developing economy saying, "the share of labor in the growing net output has increased because greater investment has been made in maintianing and increasing the quality of labor." 7 For this study the rate of literacy will be uised as the indicator which will represent investment in and achievement of an advancing level of education. Literacy was chosen simply because it is the only indicator related to education which was both available and consistent among the seven nations. As will be seen in chapter 8 , the rates of literacy published by UNESCO for the seven nations are in some cases not very current and in others rather sparse. But there is enough data for all the nations to draw conclusions which support and are consistent with the rest of the data.

The pattern for which this study is searching is based on the expectations for an economy in transition toward modern economic growth as defined by Simon Kuznets. The pattern as a whole includes the set of indicators described above, with the GDP indicators providing the context for the others. GDP indicators are normally thought of as growth-type gauges, and, by themselves, simple growth is the best which can be taken from them.

${ }^{7}$ Simon Kuznets, op. cit., page 185. 
But while they are necessary elements of the transitional pattern to modern economic growth, they must be accompanied as well by the internal, structural indicators. Those are the three sectoral indicators, the use-of-output indicators and the educational indicators.

An implication of this study is that in an underdeveloped economy the application of policy should incorporate an awareness of the indicators discussed in this chapter. But the indicators are not of equal value or meaning throughout the development process. Thus it is important to recognise that some of the indicators described here are causal and others are effect indicators. Which they are, however, may vary over time as the development process changes the relationships among them.

Initially, for the policymakers, for example, education is a causal variable. It is the key to preparing the economy for the incorporation of science and science fed technology. Education will positively impact the changes in industry and agriculture which Kuznets distinguished as characteristic of modern economic growth. Figure $1 \mathrm{~b}$ describes these relationships in a schematic representation.

As education represents a key causal variable for policymakers, it can also be used as an effect variable in just the way it is being used in this study. Literacy, here, functions as an indicator of development because an economy which is characterized by modern economic growth requires near universal literacy.

On the other hand, the increasing role of industry and the decreasing role of agriculture in the economy function as effect variables for the policymaker as well as for the evaluator of the policy. In either case the percentage of output attributable to industry and agriculture are the results of other policy application including that of education. Domestic savings also may function as a causal variable, particularly with 
respect to gross domestic investment, but at the same time it functions as an effect variable with respect to GDP.

Private consumption per capita is seen here as an effect of GDP per capita, while private consumption as a percentage of GDP is represented as an effect of domestic savings and gross domestic investment. Gross domestic investment per capita, like private consumption per capita, is clearly an effect variable in that it is a function of the absolute value of domestic investment and the size of the population. GDP per capita as well, is simply an effect variable in that it is simply a function of GDP and population size. And yet, like the other effect variables, it should provide development policymakers with an evaluative look at the economy for the application of causal policy tools, many of which are not mentioned in this evaluative package.

What is important for this study is not the yield of any particular indicator, though many are telling in their own right. Rather, it is the indicators taken together, the pattern of the combined indicators, which will allow conclusions to be reached as to whether the economies have undergone development or growth.

Comprehension of the progress from the pre-development level of the economy, the primary production level, to the mature economy which incorporates the current technology, requires indicators which illustrate the change in structure. Those are indicators, such as those described earlier in this chapter, which will disaggregate the 'growth' to reveal realignments within the sectors.

The writings of both Kuznets and Rostow support the selection of indicators discussed in the previous section. In this study the distinction between simple growth and the complex transformation of development in keeping with the statistical findings of Simon Kuznets. A nation will be observed to have undergone development if all the following criteria are met:

1. GDP - a sustained increase of at least $2 \%$ per year. 
2. GDP per Capita - a sustained increase of at least $1.5 \%$ per year.

3. The three major sectors as percentages of GDP:
a. Agriculture - a decrease of more than $20 \%$.
b. Industry - an increase of more than $20 \%$.
c. Services - no significant change.

4. The Use of Output:

\section{a. Private Consumption}

- as a percentage of GDP - a decrease to no more than $65 \%$ of GDP.

- per capita - an increase of three times the initial level.

b. Domestic Savings as Percentage of GDP - an increase to at least $15 \%$ of GDP.

c. Gross Domestic Investment:

- as percentage of GDP - an increase to at least $25 \%$ of GDP.

- an increase per capita.

5. Literacy - an increase to approximately $90 \%$ of the adult population.

Pack and Westphal stated the key requirement for policy focus on development in their 1986 article, "Industrial Strategy and Technological change". 8 In the developing economies of Taiwan and South Korea the intervention by the leadership of the nation has been geared to seeking "profitability" on a social level as well as on a private level.

Resource allocation in the circumstances of a developing economy must be geared to increasing the capacity of the nation as a whole. This is a long range objective which requires careful interim decisionmaking. Sub-national decisionmaking under those conditions is subject to national objectives. ${ }^{9}$

\footnotetext{
8 Howard Pack and Larry Westghal, "Industrial Stralegy and Technological Change", Journal of Development Economics, Vol. 22. 1986.

${ }^{9}$ In the case of these sumall countries sub-national decisionmaking would typically refer to that made on the level of the firm. Generally, however, it would imply any decision made outside the constraint of national coneerns.
} 
It is this element which was missing among the CANs during the period of growth and collapse following World War II. Among the CANs the sub-national decisionmaking was not subject to concerns for national "profitability". Economic policy among the CANs was based on the assumption that the state of the national economy would be 'naturally' or automatically strengthened through the function of the free market mechanism. On a theoretical level the assumption was that sub-national decisions would automatically conclude in improving the welfare of the nation as a whole.

Among the CANs, as a result, with the partial exception of Costa Rica, there was little investment in either the physical infrastructure or the human capital aspects of the development process. There was also no guidance of private investment to generate a "dynamic comparative advantage" as was consistently and intentionally pursued in Taiwan and South Korea.

As will be seen in the next chapters, through intervention and guidance of the development process the ENICs accomplished the sustained increases in GDP per Capita, the changes in the relationships among the sectors, the changes in the uses of output, and the increases in the education in the education and skill levels of the population which are associated with the accomplishment of modern economic growth as defined by Simon Kuznets. That is to say, in the terms of Kuznets, the ENICs managed to accomplish the incorporation of science and science-fed technology into the majority of the economy.

The next chapters will also illustrate the failure of the CANs to achieve modern economic growth through the policy of reliance on strictly market-based decisions made on a sub-national level. The CANs, in fact, failed as well to achieve the simpler goal of sustained economic growth alone. Although many sub-national units, individuals and firms, did very well during the period, these nations suffered disasterous decline. 
The following chapters, five through seven, describe the historical circumstances for the economic policy decisions by the two groups of nations. In chapter eight the statistics for the seven nations will be presented for the period under consideration. In chapters nine and ten observations will be made and conclusions drawn regarding the demonstration of consistent patterns of development among the seven economies, as structural transformation. This is in keeping with the expectations of Kuznets' modern economic growth.

The nature of the development process as described by Kuznets emphasizes the fact that it is characterized by a complex change in the economic and social structure of the nation. Given the variety of starting points for the development effort, the historical and physical environment and the cultural differences among the developing nations, tracking the process requires a search for patterns of change rather than expectations of particular changes.

None of the individual indicators can be taken alone as indicative of development. The studies by Kuznets and others illustrated that the achievement of modern economic growth involves the complex of changes represented by the array of indicators depicted in Figure 1 above.

In this study the expectations for development include first, a sustained increase in GDP, secondly, a sustained increase in GDP per capita, and thirdly, a structural change in the three major sectors characterized by a decrease in agriculture as a percentage of GDP with a consistent increase in the industrial sector and little change in the services sector. Forth, changes in the uses of production should appear as decreased private consumption as part of the total output while private consumption increases on a per capita basis, together with increased savings and increased domestic investment as a part of total output. And finally, a substantial investment in education 
should be evidenced in an increase in literacy commensurate with the high level of literacy necessary to an industrialized economy.

It is appropriate to make something of a disclaimer in this chapter of the study. There are many alternative explanations for the crises among the CANs and the successes of the ENICs. The fact that the two groups of nations approached expansion policies on such different bases is, at best, only part of the story.

Aside from the cultural and historic differences which will be briefly explored in the next chapters, there are many other distinctions which undoubtedly contributed to the two very different outcomes. While both Taiwan and South Korea were recognized to be populous small countries after World War II, only El Salvador among the Central American countries would have been described as heavily populated. The other four CANs still had a relatively high ratio of land to population. Thus, a number of international development agency studies, early in the post-war period, advised labor policies which made the high unemployment problems worse.

Another important difference between the CANs and the ENICs was the strength of the governments. Both of the ENICs were governed by an authoritarian elite which was able to establish and maintain policies with security. This created an atmosphere of relative stability which far exceeded what the CANs were ever able to attain. Thus internal policy could be applied and carried out with certainty, and external relationships could be used to advantage as well. No doubt that is part of the reason that the ENICs were the beneficiaries of more substantial flows of both foriegn aid and capital investment than the CANs.

Another clear disadvantage for the CANs was the looming presence of the United States throughout the period. Not only did the U.S. dictate broad policy guidelines to the CANs, but it also accounted for the majority of their external markets. The U.S. made clear several times during the post-World War II period that it would 
not tolerate a strong nationalist government on the isthmas. Thus, the Central American governments were regularly preoccupied with both internal and regional strife throughout the period. Whether these circumstances provide an adequate explanation for the failure to sustain economic expansion is, to say the least, open to doubt. On the other hand, that the failure or inability of the Central American governments to undertake the structural transformation necessary to sustained economic expansion contributed to the high level of strife in the region has been suggested by many commentators.

Finally, it is worth mentioning here that the author was warned both at the UN and at the World Bank that all statistics from Central America must be viewed with skepticism. The Area Officer for the Regional Bureau for Latin America and the Caribbean at the United Nations stated that "You must be careful with any of the figures from the World Bank Studies. They always exaggerate, the (Central American) governments I mean, when those figures are collected." A World Bank economist who has been working primarily with El Salvador confirmed the truth of that comment, stating that he was startled recently to discover that the data from El Salvador shows an "a very high level of income equity...amazing!"

In terms of this study, that simply has to be viewed as one of the constraints. An ameliorating consideration here, however, is that errors and exaggerations will tend to be either absorbed, or to become more obvious in the three-decade span of the data. They will also tend to have overstated any development among the CANs. A potential problem which, as will be seen in chapter eight, does not seem to have damaged the case for drawing clear distinctions between the ENICs and the CANs. The distinctions between the two groups, based on the Kuznetsian indicators, is dramatic and clear. The ENICs developed entirely consistently with the expectations of Kuznets while the CANs clearly did not. 


\section{CHAPTER V}

\section{THE CULTURAL AND GEOGRAPHIC BASIS IN CENTRAL AMERICA}

\section{PRIOR TO WORLD WAR II - SPANISH COLONIES AND INDEPENDENCE}

Central America was a backwater of the Spanish empire throughout its colonial history. In keeping with the character of imperial Spain, the conquest generated fiefdoms throughout the area, accounting for decades of feudal warlord-like politics and for the character of an elite with a sense of divided interests and identity.

Historically, Central America was made up of the five small nations, Costa Rica, El Salvador, Guatemala, Honduras and Nicaragua. Each of the tive are distinct in some respects, but most differences are a result of the interaction of geography and the historical, particularly colonial, response to it. Guatemala, for example, was from the time of the conquistadors the center of political and economic power for the region. It was geographically suited to plantation agriculture and it had a substantial indigenous population to be incorporated into a forced labor system.

Guatemala was not a major prize for imperial Spain, it had little in the way of precious metals, but it did produce some agricultural wealth for the empire. Costa Rica, on the other hand, was of no economic consequence. It is a very mountainous region which was sparsely populated, and so, produced nothing of interest to the colonists. The other three nations which have a shared history existed somewhere on the continuum between Guatemala and Costa Rica. They had some capacity for large scale agricultural production and some indigenous population for labor. 
Several commentators place a good deal of emphasis on the fact that the area shares a mutual history and that there has long been a tendency among Central Americans to identify the five Central American states as a single nation. ${ }^{1}$ Besides the common language, the common culture and the history, since independence from Spain in 1821 political unification has been a strong and multifaceted theme in Central America. A recent manifestation of that theme is the Central American Common Market (CACM) of the 1960s and 1970s, around which was woven considerable discussion of political integration. The potential for political integration was firmly thwarted by the elite in each of the five nations, however, as it has been regularly since the breakup of the federation in 1838 .

Independence essentially fell upon the five Central American states in 1821 through their temporary annexation to Mexico. By 1823, while Mexico was convulsed by civil war, a Central American congress proclaimed its independence from Mexico and established the "Federation of Central America".

After a stormy fifteen years of existence without adequate financing, the Federation finally collapsed over the refusal of three of the five states to grant taxing authority to the Federation. Since 1838 the region has been composed of the five independent nations which still function politically autonomously within a loose identification of common interests. 2

Both during the colonial period and during the early period of independence, "Local elites, landowners and merchants, guarded their autonomy zealously and viewed the colonial (and independent seat of government) in Guatemala City with considerable

\footnotetext{
${ }^{1}$ See, for example. John Weeks. The Economies of Censml America. New York. Holmes and Meier. 1985, pages 811, and the classic on the suhjett, Ralph Lee Wondward, Jr. Central Amerien: A Nalion Divided, New York, Oxford University Press. 1973.
}

2 Panana and Belize hoth have a distinct origin and historical development. 
antipathy." 3 That the autonomy of the local elites is still zealously guarded is clear in political interactions right up to the present. Both the form of the $\dot{C} A C M$ and its fairly rapid demise were a function of that zealousness. The fact that the organization had almost no supranational authority has been commented upon regretfully by many Central American writers.

\section{The Elite}

The intentions and the capacity of the elite to govern is of considerable importance for any development process. In his The Stages of Economic Growth, for example, Walt Rostow made quite clear that a necessary condition for 'take-off' in a nation which is undergoing economic development is an elite which is capable of opposing the traditional landed interests. More specifically, this elite must be "prepared to regard the modernization of the economy as serious, high-order political business." 4

Among the five historic nations of Central America there is considerable reason to observe that that preparation is missing. The elite on the whole are far more readily characterized by their resistance to modernization than by their encouragement and support of it. Hector Perez-Brignoli, Professor of History at the Universidad de Costa Rica writing about the current crisis says that "...landowners and business people were unable to transform the agrarian capitalism instituted at the close of the nineteenth century." "It matters little whether we refer to the ruling class as bourgeoisie, oligarchy, or aristocracy. The fact is that they did not succeed in forging a new collaboration and consensus to replace the crumbling colonial paternalism. Control rested therefore exclusively on exploitation, violence and terror." 5

3 Weeks, op. cit.. p.9.

${ }^{4}$ W.W. Rostow. The Stages of Economic Growth. New York. Cambridge University Press. 1969. p. 9. 
Perez-Brignoli further states that, "The profitability of businesses and use of modern technology are not at issue. Rather, it is economic efficiency without correspondingly suitable social relations, and growth without distribution. ...the lack of political will and the cultural precariousness of the ruling elite (are key determiners of the outcome of the development effort)." ${ }^{6}$ Among Central American writers this is not an unusual perspective. Edelberto Torres-Rivas has written many books and articles which cite the failure of the elite. In a 1980 article, "The Central American Model of Growth: Crisis for Whom?", Torres-Rivas argues that policy decisions on the part of the elite were clearly geared to avoiding the structural changes which characterize the development of the industrialized economies. ${ }^{7}$ Torres-Rivas develops the theme in more depth in his Centroamerica: La Democracia Posible (1987) and Crisis del Poder en Centroamerica (1989). ${ }^{8}$

John Weeks, another well published writer on the subject, seeks to "...explain the uniquely reactionary nature of the region in terms of its land-tenure systems" in an article in the Latin American Research Review (1986). ${ }^{9}$ There are many more, but these give a sense of the well-recognized nature of the problem of leadership for development in the region. Although some industrialization has taken place in recent decades, the economies are still dominantly agricultural, the industrial production is

\footnotetext{
5 Hector Perez-Brignoli. Breve historia de Centroanterica. Madrid, Alianza Editorial, 1988. p. 181-182.

${ }^{6}$ Perez-Brignoli. op. cit., p. 182.

7 Edelberto Torres-Rivas. "The Central American Model of Growth: Crisis for Whom?". Latin Almerician Perspectives,
} Vol. VII. \#s 2 \& 3. 1980.

${ }^{8}$ Edelberto Torres-Rivas. Cuntronmerica: La Demecracia Pasible. EDUCA. San Josc. Costa Rica. 1987 and Crisis del Poder en Centroamerica, EDUCA. San Jose. Costa Rita. 1989.

9 John Weels. "An Interpretation of the Central Amurican Crisis". Latin Amurican Rusuarch Review. Vol. XXI, \#3, 1986. 
essentially for industrial country markets, and income distribution is so dramatically poor that internal markets are minimal. 10

\section{The Agricultural Base}

A study of family networks in Latin America describes the institution of the family in Central America as the major means of preserving and using status and wealth. ${ }^{11}$ The study compares Central America to Mexico City and Lima in the depth of its history. While Buenos Aires and other areas in Latin America were beginning to emerge in the nineteenth century, "Central America was an old colony with deep-seated traditions. Its institutions, labor and land tenure patterns were hundreds of years old when (those other regions) were beginning to evolve." 12

For the most part, throughout much of that history the region was one characterized by a subsistence type of agriculture, even on the large estates, with little internal trade and few exports. During the colonial period, other than a trickle of precious metals from Honduras, the first export of significance was cacao, sent to Europe through Mexico. By the nineteenth century the region had become a net importer of cacao, though in the meantime indigo dye had replaced it as the export of significance. The third export of any note at all was cochineal, a red dye made from insects, which was exported briefly by Guatemala in the first decade of the nineteenth century.

The pattern of land and labor expropriation established in the conquest was reinforced each time an export crop was developed. Zones of subsistence or near

\footnotetext{
10 Torres-Rivas, for example, in "The Central American Model of Growth: Crisis for Whom?" states that "...wage levels were so low as to seriously limit the formation of an interior market. (so that) the "wage earner" was not a consumer." p. 28.

11 Diana Balmori. Stuart F. Voss and Milss Wortman. Family Networks in Latin America. Chicago, University of Chicago Press, 1984.

12 Balmuri. el al. up. cit., p. 53.
} 
subsistence agriculture became areas of monoculture. In El Salvador in the mideighteenth century when indigo became the valuable crop, it literally replaced food production in many areas. All the territory within the dye producing region became sufficiently valuable to warrant the use of force to remove Indians from their common lands as well as the subsistence farmers. This also increased the pool of low cost labor. Finally, in the latter half of the nineteenth century, the region entered into the world economy to a serious degree through the export of coffee. By 1880 four of the five Central American republics had begun exporting substantial amounts of coffee. The move to coffee as the main source of wealth and power for the elite, however, served to extend and reinforce the system of land use where concentration of landholding confined the peasantry to marginally productive land.

Banana production as well was introduced in the latter nineteenth century. Banana production also introduced foreign capital directly into the productive realm, again with the result of reinforcing the land and labor use which had characterized the region since the conquest.

The cotton boom in the mid twentieth century further reinforced the pattern, particularly in areas which were previously considered marginal land. In Nicaragua, El Salvador and Guatemala, cotton became either the first or second most important export in the 1960s. It also shepherded in a more capital intensive form of agriculture. Unlike coffee and banana production, which require labor intensive methods, cotton is best produced using capital equipment and inputs such as fertilizers and pesticides. This time when the former tenants were forced off their land there was little employment for them in the context of the new export crop. The cotton boom again increased the number of landless wage laborers who now began moving into the urban areas in search of industrial employment. 
Foreign Domination

Foreign domination has been a feature of life in Central America at least since the Spanish conquest in the sixteenth century. Although exports from the region were of minor importance to the Spanish empire, and there were lengthy periods when parts of the region lapsed into subsistence and self-sufficiency, it was clearly governed with the intent of extracting whatever wealth was available. The Spanish colonists during that period functioned as intermediaries in the process.

With the collapse of influence of the Spanish monarchy in the early part of the nineteenth century, a period of internal struggle for power characterized the politics of the region. In part the struggle was a function of the fact that each of the five states refused to forego sovereignty to any of the others. But it was also characterized by what was to become a longstanding conflict which is typically described as that between conservatives and liberals.

The Conservatives were, for the most part, looking to retain the character of global isolation in the region. This is generally characterized as emphasizing the retention of the colonial social and economic structure represented by land-based wealth and a dominant position for the church.

The Liberals, on the other hand, represented an anti-clerical attitude, support for strengthened state power and an impulse toward engagement with world trade. This required considerable structural change in the latter part of the nineteenth century when Liberals dominated the Isthmus. In order to support an export economy it was necessary to change the social structure and to rearrange the availability of all the factors of production, land, labor and capital. Accordingly, the church was eliminated as a power through, among other things, the expropriation of land. The local oligarchies were forced to submit to centralized governments, and the requisite seasonal labor was made available through revisions of the law to revive the colonial system of forced labor. 
The considerable increase in public expenditure which was required for infrastructure of all sorts, opened the region to foreign loans, and ultimately to a wide range of foreign investment. Promotion of foreign investment led to the control by foreign interests of the banking, the financing of the export trade and even much of the export infrastructure. Ultimately, however, the basis for economic and political power for foreign capital was land and agricultural production, just as it was for the local elite.

\section{Labor in the 'Export-Led' Economy}

Thomas P. Anderson in his Politics in Central America points out that "For most of the postconquest period the campesinos (the peasant farmers) have been unrelentingly exploited by those who owned the land." 13 During the colonial period the indigenous people were simply forced to render tribute labor to the Spanish conquerers. Following independence the forced labor system was dropped in favor of a debt peonage arrangement under which the peasants were securely tied the their landlords.

Various subsequent arrangements were made to reinforce the peonage laws. In the latter nineteenth century in Guatemala, for example, a set of vagrancy laws made it a criminal offense not to work a specified portion of the year as a wage laborer. This law, which stayed on the books until the middle of this century, required 150 days of work per year. Workers were required to carry a passbook into which employers entered their job records as evidence of compliance with the law.

As described by John Weeks in the introduction to his The Economies of Central America, though there were official justifications for these laws, "The actual function was to insure a docile and cheap labor force for large scale agriculture." 14

13 Thomas P. Anderson. Polities in Central America. New York. Praeger. 1982. p.11. 
The demand for cheap labor for agricultural production was even apparent in the constitutions of El Salvador and Guatemala. Both required that vagrancy be made a punishable offense.

The entry of foreign capital directly into agricultural production in the last decades of the nineteenth century reinforced rather than weakening the forced labor system. Banana production was almost exclusively a function of foreign investment, and coffee, though an important domain of the local elite, engaged considerable foreign investment. Both export crops were produced on the basis of the centuries-long tradition of forced labor. With the liberal rule, however, particularly with regard to coffee, the methods were modernized. "Governments in El Salvador from the 1870s onwards, under pressure from the coffee elite, granted or sold public lands to private individuals and alienated communal or church lands with such vigor that access to land on the part of the mass of the rural labor force was severely restricted. (Therefore) 'market forces' could be used in lieu of coercion to obtain the necessary seasonal labor inputs. "15 Nicaragua and Guatemala were able to use similar resort to 'the market' in combination with the more traditional coercive approach.

With some relatively minor variations the fundamentally coercive model of labor relations characterized the economy of Central America through the middle of this century. Since coffee was not only the dominant export crop in the region, but the prime source of wealth, it was critically important that it remain profitable. Therefore, since the profitability of coffee depended almost solely on the control of labor costs, labor unrest was quickly and ruthlessly quelled. The history of the region is rife with accounts of barbarous official responses to rural labor protests.

\footnotetext{
14 John Wetks, op.til., p. 15.

15 Vietor Bulmer-Thomas. The Political Econome of Cennral America Since 1920. Cambridge, Cambridge University Press, 1987. p. 21.
} 


\section{THE POST WORLD WAR II PERIOD}

Costa Rican historian Perez-Brignoli lists the characteristics of the nation-states which formed during the nineteenth century in Central America. The strongest of these were the centralization of administrative power, the clarification of territorial boundaries and the creation of military forces to assure internal order and defense. Less firm attributes include a legal framework which continued to exist alongside "personalism and arbitrariness", a modest degree of bureaucratization with a corresponding decrease in "personalismo" (Personal decisionmaking in government) and something of a broader national identity within the five states. ${ }^{16}$ This list of characteristics is for the most part appropriate yet today.

In his history of the region Perez-Brignoli refers to the first half of the current century as the "years of impoverishing growth". This was due to considerable extent to the unvarying dependence on coffee and banana exports as the basis for national wealth. Both were operated as broadly extractive processes with as little reinvestment as possible, especially in land and labor. Banana production, almost exclusively dominated by foreign interests, has from the beginning been treated with a sort of 'slash and burn' mentality. That is, when production began to decrease or become difficult due to crop diseases or labor problems, for example, the response was to simply move operations to another region.

Coffee exporting is described by Perez-Brignoli as allowing the region to maintian economic growth throughout the first half of the century. This growth was attained, however, through the reinforcement of the social order which was established

\footnotetext{
${ }^{16}$ Hector Perez-Brignoli. Breve historia de Centroamerica, Madrid, Alianza Editorial. 1988. p. 104.
} 
by the Liberal reforms of the 1870 s and 1880 s and the increased subordination of the interests of the ruling elite to those of foreign capital. 17

That period was one of increasing repression throughout Central America, and one characterized by the establishment of a habit of internal violence which still characterizes the region today. The United States resorted to military intervention several times in order to 'stabilize' the political situation and the national police and armies were used regularly to quell agricultural labor unrest. A frequently cited event in that historical theme is the El Salvadorian peasant revolt of 1932. During the brief insurrection thirty landlords and overseers were killed by the rebels. The response on the part of government troops left an estimated fifteen to twenty thousand peasants dead.

This event marked something of a watershed in the seriousness with which the military was regarded by the oligarchy in the region. Subsequently, much of the character of the military as the means of maintaining quiet in the countryside was based on the fear of another such revolt. Following that uprising the military-based regimes for which the region became known were well supported by the ruling elite for the purpose of enforcing the status quo.

World War II brought some modest prosperity to Central America. The outbreak of war disrupted the shipping to Germany and Britain on which the Central American nations had come to depend heavily. But the establishment of markets in the United States changed the course of prosperity for the region. Bulmer-Thomas illustrates the change in markets using a table which shows exports to Europe all but disappearing by 1940 while those to the U.S. increase to account for most of the agricultural exports (bananas and coffee). ${ }^{18}$

17 Hector Perez-Brignoli. op. cit.. p. 107.

18 Victor Bulmer-Thomas. op. cit. p.92. 
While exports were assured, imports were more difficult to come by. As a result four of the five republics ran a trade surplus, which, together with the post-war increases in prices for coffee and bananas, created an environment of well-being accompanied by a wave of reformist politics.

Especially Guatemala and Costa Rica experienced dramatic impetus to reform. In Guatemala a weak, corrupt regime was replaced by a reform-minded popular coalition government in 1944. In the succeeding ten years the vagrancy laws were overturned, labor rights laws were initiated and land reform was undertaken. By 1954, however, the changes had put such pressure on the oligarchy and on foreign investment interests in the country that the popular government was declared communist and overthrown in a U.S. CIA managed invasion from Honduras and Nicaragua. As described by Weeks, "With the fall of (the Arbenz government), Guatemala entered a dark age of repressive dictatorships shocking even by Central American standards. "19

Costa Rica fared better. In this case the reform was strictly political, not disturbing the distribution of income or wealth. A nearly bloodless civil war in 1948 led to the institution of honest elections and to the decrease of corruption and nepotism in national government. In 1950, under the new legitimately-elected president, the army was permanently abolished and many labor and social welfare reforms were instituted.

Honduras, Nicaragua and El Salvador similarly undertook mild reforms which were neither threatening to the elite nor, as distinct from those in Costa Rica, were they long lived. In all five nations the ownership and distribution of land continued to be the key political issue. Again Weeks puts it succinctly, "Economic (growth) in the region, rather than diminishing the importance of this (land) issue, has intensified it. Agribusiness has given the landed oligarchy a new and growing base of economic and

\footnotetext{
19 John Wecks. op. cit.. p. 27.
} 
political power, so that land ownership still determines the relationship between the privilaged and the underprivilaged. $" 20$

\section{The Agricultural Base}

Central America entered the post-World War II period with income and wealth based primarily on the production of coffee and bananas for export. In the 1950 s and 1960s two new cash crops, cotton and sugar cane were added to the region's agricultural export economy. By the 1970s Guatemala, El Salvador and Nicaragua were producing nearly six percent of the world's cotton. That rapid expansion, however, was accompanied by the displacement of thousands of small farmers in the coastal plains of all three countries, and massive use of the pesticides and fertilizers which have come to haunt those regions. 21

Edelberto Torres-Rivas pointed out that "The introduction of cotton in $\mathrm{El}$ Salvador is most tragic from the point of view of the country's displaced population." But further, since most of those regions had previously been used to produce food staples, the displacement resulted in a rapid increase in food imports. In Nicaragua, says Torres-Rivas, food imports increased five times between 1960 and 1977, the same rate of increase as cotton exports. 22

U.S. sugar imports from Central America tripled in the 1960s. This was to a considerable extent due to the switch of sugar quotas to that region from Cuba. As with cotton, though in different regions, campesinos were displaced and ownership of land was consolidated under more powerful ownership.

\footnotetext{
20 John Weeks. op. cil.. p. 34.

21 See, for example. Victor Bulmer-Thomas. op. cit. p.106. Hetur Perez-Brignoli. op. cit., p. 137, fr, John Weeks. op. cit. p. 101. rf.

22 Edelberto Torres Rivas. "El Dessollo de la Agricultura en Centroamerica", in Confederacion Universitaria Centroamericana (CSUCA), Documentos de Estudios, San Jose, July 22, 23, 1982.
} 
Beef is another agricultural product which became added to the short list of new exports. It is generally ranked fourth or fifth on the post-World War II list of agricultural exports. Though beef consumption is low in Central America as a whole, beef production has long been a cultural phenomenon associated with wealth. Beef consumption was, for the most part, a privilage of the elite. The increase in demand in the U.S. for inexpensive, hamburger-quality, beef is usually cited as the key stimulator of the increased production in Central America. From 1960 to 1980 meat exports from Central America increased seven-fold and estimates suggest that by 1980 approximately fifteen percent of U.S. meat imports came from Central America. 23

Many commentators have described as a serious error the Central American policy toward expansion of agricultural production through emphasis on an "agricultural frontier". Studies by the International Bank for Reconstruction and Development (1953), among others by international agencies in the early 1950s, warned that economic development may be impeded by labor shortages. As a result, the wisdom of the day emphasized the introduction of crops which were consistent with the use mechanization and minimal labor. Bulmer-Thomas states that "Far from permitting Central America to escape some of the pitfalls of export-led growth, the land frontier was used to introduce new export crops on the pre-war pattern so that the benefits of export diversification and capitalist modernization were as narrowly distributed as before." 24

\section{Foreign Domination of the Agricultural Base}

As with coffee in the five nations, though the land is often locally owned, the infrastructure of cotton and sugar cane production is foreign financed and the links to

\footnotetext{
23 Victor Buimer-Thomas. op. cit. p.157-158.

24 Victor Bulnuer-Thomas. op. cit. p. 106.
} 
international markets are owned abroad. Trans-national corporations and other foreign investors have long financed the production and the infrastructure for coffee. Cotton and sugar cane production was developed in imitation of that pattern, typically with the assistance of, and often with guarentees from, the U.S. Agency for International Development (AID), the World Bank, and the Inter-American Development Bank (IDB).

Banana production in the region for more than the last hundred years presents a somewhat different pattern. Land, in this case, is not owned by the local elite. It has been owned and directly controlled by what in Central America was often referred to as "los pulpos" (the octopi). They appeared to be connected to everything. Still today most of the banana production is controlled by United Brands, Castle and Cook and R.J. Reynolds.

The actual production of bananas has always taken place in isolated enclaves. As a result the banana companies established their own banks, breweries, restaurants, stores, shoe and clothing factories, plastic and cardboard container production plants, and so on. Then, in the early part of this century the companies expanded their already substantial investment in infrastructure which included utilities, ports, railroads and communication systems.

In the 1960s, when the Central American Common Market established broader trade possibilities in the region as well as with international markets, the companies dramatically increased the range of food processing investment to include vegetable and fruit farming and canning facilities, cattle ranches and more elaborate shipping facilities. But they also began to revise their relationship to agricultural production to more nearly approximate the pattern among the coffee, cotton and sugar cane producers. In recent decades there has been a movement toward turning over the farming of the land to local farmers. Actual ownership of the land is typically retained 
by the company and a tenant farming arrangement is made with groups of campesinos. This eliminates the seasonal risk for the companies while retaining complete control of the production capacity.

Cattle production, the last of the five key exports of the region, began its expansion in the 1950s. Again, with the assistance of the U.S. AID, the World Bank and IDB the sector expanded dramatically in the 1960s and 1970s. Large percentages of the agricultural loans were dedicated to expanding cattle production. In 1975 a World Bank paper noted that lending for livestock operations "continues to be the single most important type of credit activity."

The critical and often cited question, of course, is what the expansion has done to land use patterns in the region. A 1983 study by a United Nations agency found that in Honduras cattle occupied sixty five percent of the largest and most fertile landholdings. 25 Even a U.S. State Department report referred to it as "a quick and dirty business", where the investor extracts profit from the operation as quickly as possible before what is often former forestland becomes too eroded to produce grass for cattle. 26

The ownership of the land and the production of cattle, though a serious commercial undertaking in the region, is also culturally associated with privilage and wealth. Thus ownership of the ranches is rarely in the hands of foreign investors, though the financing generally is. The slaughter, packing and shipping processes, also are commonly foreign owned or financed.

The final realm of agriculture which is foreign dominated is that of the so-called "nontraditional exports". During the 1970s U.S. AID introduced the catagory and

25 Jacobo Schatan. La Aggroindustria y el Systema Ceniroamericano. Mexieco, CEPAL, 1983, p. 46.

26 AID. "Agribusiness Employment/Investment Promotion." ROCAP Projett Papur. Washington. D.C.. May I5, 1981. 
offered financial support. These exports included such things as exotic flowers, shrimp, sesame seeds, broccoli and snow peas. The stated intention of both the Central American governments and AID was to provide additional sources for foreign exchange and move the nations away from strict dependence on the five 'traditional' cash crops.

The nontraditionals are an almost exclusively U.S. focused endeavor. The markets, the financing and the processing facilities are controlled by foreign, generally U.S., investors. ${ }^{27}$ The effort is considered to have had mixed results so far in Central America where stories are rampant about small farmers who found the nontraditionals to be more expensive and riskier than the traditional crops. The markets have also proven often to be unreliable. There have even been instances of U.S. producers blocking the shipments of ripening Central American crops.

\section{Labor in the 'Export-Led' Economy}

On the whole, the post-World War II environment for labor in Central America is little different from that of the previous four centuries. Among urban workers, some activity in organized labor began to appear in the 1920s, a period of relative stability in the region. By the end of the decade, however, the activity was brought to a dramatic end.

The onset of the depression in 1929 marked the end of the liberal oligarchic state throughout Central America. In Guatemala, Honduras and El Salvador labor activity was relentlessly destroyed shortly thereafter. In Nicaragua, under U.S. occupation throughout the 1920 s, organized labor stayed moderately active well into

\footnotetext{
27 One of the many examples of this attivity is Foodpro. a subsidiary of National Starch and Chemical which is itself a U. S. subsidiary of the British/Dutch Unilever Comporation. Fooulpro, one of several U.S. AID finaneed producers in Honduras. holds an AID coniract to grow snow peas and brocicoli near Tegucigalpa. A much larger operation is organized through the Latin American Agribusiness Development Coporation (LADD) crealed by BankAmerica as a conduit for AID investment funds. As of 1986 LADD represented 160 trans-national eorporations investing in Central Ameriea. A useful initial resouree for more information on this type of investunent would be: Tom Barry and Dehra Preusch. The Ceniral Ameriea Fact Book. New York, Grove Press, 1986, pages 11-26 and 155-160.
} 
the 1930s, but by 1939 had gone into what Bulmer-Thomas calls 'self-liquidation'. 28 Typically, in Costa Rica the response to labor throughout the 1930s was moderately repressive but not completely intolerant.

In the mid-1940s a revival of organized labor in the urban areas accompanied the freer economic and political environment. The activity rarely touched the rural workers, however, except for some militancy and strikes among the banana regions. By the latter 1940s reaction had set in among the five neighboring governments and the prospects for labor dimmed considerably.

The small number of urban workers represent an important part of the 'leading edge' of any evolutionary movement toward modern economic growth. This is a leading edge, however, which has been thoroughly hammered down by the environment of repressive economic and political policy. At that, this potential 'leading edge' constitutes a very small part of the working population of the region. As John Weeks put it, "the Central American countries are not predominantly wagelabor societies. The proportion of permanent wage earners with no links to the land is small in all of the countries, and 'the land question' is of tremendous social and political importance." 29 Following World War II the conditions for rural labor changed little from what it had been for centuries, except that with the introduction of the new export crops the percentage of landless rural families increased substantually. Central American studies showed that by 1970 over one quarter of rural families were landless in the region as a whole. ${ }^{30}$ The same studies indicated that by the latter 1970 s

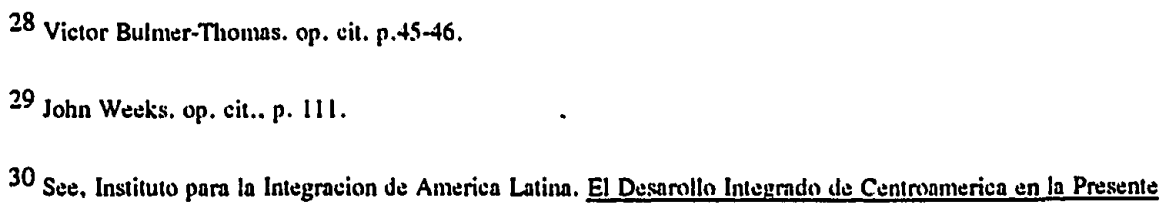

30 See, Instituto para la Integracion de America Latina. El Desarollo Inlegnado de Centromerrica en la Presente Decada, Vol. 5, Buenos Airss, 1973, also. Secretaria Permanente de Tratado General de Integracion Economica Centroamericana (SIECA). Estadisticas sohre Alimentacion y la Agricultum en Ceutroamurica. Gualemala. 1972 and SIECA. Commendio Estadistico Centroamericano VII. 1981. 
the number of agricultural families with insufficient land to sustain themselves ranged from sixty percent in Nicaragua to eighty seven percent in El Salvador. Much of this is essentially a function of the export-led growth policies of the period, and in that sense not a lot different from similar historic events in the eighteenth and nineteenth centuries in Europe. What make the Central American experience different is that the commercialization of agriculture there took place in the context of a coercive system of labor relations inherited from colonial times.

Among the small 'leading edge' of urban workers the post-World War II organizing activity was continued, with considerable difficulty, as a minor political theme until $1954 .^{31}$ It was in that year that the legitimately elected Arbenz regime in Guatemala was overthrown by the CIA-organized "Army of National Liberation". As described by Perez-Brignoli, when Arbenz stepped down from the presidency, "violence replaced politics and real power passed into the hands of the military. The Guatemalan regime came to be archtypical. The preeminence of the executive branch facilitated the centralization of power by the military while the main source of legitimization became approval by business leaders, legalized political parties, the church and the military itself. Under these conditions political participation was very restricted with barely any popular backing. Repression, selectively applied, continued remorselessly. Political violence was virtually an established rule of the game.". 32

Besides the political, this circumstance reflected the structure of economic engagement by the population as well. It is a function of, and a specific continuation of, the historical arrangement of economic and political power.

\footnotetext{
31 For a substantive description of the struggle of labor during that period ste Bulmer-Thomas. Chapter 7. "The Struggle for Democracy, the Cold War and the Lahor Movenent in the First Post-war Detade". p. $130 \mathrm{ff}$.

32 Hector Peruz-Brignoli. op. cit.. p. 137. Similar observations can be found in english language texts such as those mentioned above by Bulmer-Thomas. Turns-Rivas and Wecks.
} 


\section{CHAPTER VI}

\section{CENTRAL AMERICA: THE POST-WORLD WAR II PERIOD}

\section{THE HISTORICAL BASIS}

The post-World War II growth efforts in Central America were thoroughly intertwined with the attempt to establish a Central American Common Market (CACM). The prolific writer Edelberto Torres-Rivas commented in an article on the CACM in 1980 that since "economic growth depends on the capacity for accumulation" it is important to understand "who controls this process in order to understand the forms that the accumulation takes." 1 In the case of the Common Market effort TorresRivas is concerned with the failure of effective national accumulation by Central American private enterprise. The problem, he says, focuses on the ability of the state "to direct the capitalist accumulation".

In the case of the CACM, Torres-Rivas points out, "the process (of economic development) was abandoned to the laws of the market, to the anarchic reign of private interests, the results of which could not be different from those that are presently to be observed. The larger problem, is not the regional disequilibrium that has been caused, but the social disequilibrium that underlies all this reality." "Paradoxically," he observes as a final note, "the country that has the most important trade returns in its favor, Guatemala, is the one that has the highest unemployment and the most unequal

\footnotetext{
1 Edelberto Turres-Rivas. "The Central American Model of Growth: Crisis for Whom". Lalin American Perspectives,
} Vol. VII. 1980, page 42. 
distribution of income. Nor is it coincidental that Guatemala is the country with the most anti-union violence." 2

To understand the failure of the Central American leadership in this effort it is necessary to take a look at the historical sources for the decisionmaking. With independence in the early 19th century, conflict between the social classes and between regions characterized the political and economic interactions. With independence the conflicts became intensified because there was no longer a regional political institution which had the power to focus efforts on a regional level. The force of external unification had been removed and what was left was a conglomeration of municipalities which were ruled by the wealthier Creoles. The municipalities formed no basis for regional or even national government because their power was strictly local both under Spanish rule and under independence.

The establishment of the strong national boundaries which characterized relations in the region in the 19 th and 20 th centuries has been traced to the Spanish appointed regional 'intendentes' to oversee the financial and military administration of the colony. These provincial governors held broad powers and solidified the increasing autonomy and separatist spirit in the provinces in the last years of the Spanish rule.

By the early twentieth century the successors to the 'intendentes', the national oligarchies, had turned over considerable control of their countries to foreign planters, merchants, financiers and diplomats. This often involved generous concessions which were made in order to attract investment. The early part of this century was a period in which new oligarchies emerged, primarily on the basis of the production and sale of coffee to the developed nations. But the control exercised by those oligarchies was heavily dependent upon foreign interests. A look at the period of the "banana

\footnotetext{
2 Edellerto Torres-Rivas. op. cil., page 42 and 43.
} 
republics" in Central America makes clear how intimately engaged were those foreign interests with the governing elites in the Central American countries.

In the early twentieth century historian Dana G. Monro described the political situation in Central America in terms which were still appropriate in the middle part of the century with respect to efforts to establish political and economic unions.

The difficulties in the way of uniting the five republics would not be insuperable if the ruling classes were genuinely ready to cooperate in realizing the (regional) ideal. But the men who enjoy the high offices and the control of the revenues of the state governments show a decided reluctance to giving up any of their power for the common good. The local political groups and the influential families would necessarily be reduced to a position of far less importance if the union were accomplished. The realization of this fact makes many of those who are more enthusiastic in their advocacy of a Central American union slow to take any definite steps toward its realization.

Such an observation goes a long way toward insight into the events surrounding the Central American Common Market.

\section{THE CENTRAL AMERICAN COMMON MARKET}

In the early 1950 s two mildly interconnected efforts were made to achieve unity in the region. One of these bore no fruit at all. The Organization of Central American States (ODECA) drew considerable attention in the press and involved the upper echelons of government in all five countries. But it proved incapable of confronting the intensity with which the national power bases were protected. The purposes and intentions were lofty enough. The texts describe plans to strengthen the links which unite the countries, to maintain fraternal coexistence, to assure pacific solutions to conflict and to search for cooperative solutions to needs for economic, social and cultural development.

\footnotetext{
3 Dana G. Munro. The Five Republies of Central America, Carnegie Endowmen for International Peace. 1918, page 175. This text was described in the LATIN AMERICAN GUIDE TO HISTORICAL LITERATURE in 1971 as "The slandard twentieth century work on Central America in English."
} 
The other effort, generated in the context of the United Nation's Economic Commission for Latin America (ECLA), was a narrower one based in an array of pragmatic economic goals designed to create a strictly economic unity based on limited structural change in the five economies. The effort was made, particularly on the part of the proponents of ODECA, to tie the two efforts together. But the 'tecnicos' of ECLA and the five economic ministers saw the danger in ODECA's thin and very general objectives. They successfully dissociated themselves from the attempts to combine the two because they felt that the likelihood of achieving regional agreement on the more pragmatic and limited objectives of a regional market were much more likely.

Both of the unification efforts were the outgrowth of the historical circumstances of the region immediately following World War II. A basic ingredient is that all of the countries of Central America experienced a period of moderate prosperity due to an improvement in the prices of their exports on the world market. This situation affected the countries differently due to a number of factors. The export sectors were more developed in Costa Rica, El Salvador and Guatemala, consequently they benefitted more from the increased prices. At the same time the rate of economic growth in El Salvador, Guatemala and Honduras was almost equalled by the rate of population growth so that per capita welfare was little affected in those countries and may have even diminished.

- It is important to note, however, that the prosperity was not due to an increase in production or to a structural change in the economy. Rather, it was due to the increase in prices which occurred with an unchanging level of production. Some minor industrialization had taken place, primarily in Guatemala and El Salvador, as a result of war caused shortages and lack of external competition. But by 1950, when industrialization dominated the developed world, Central America's manufacturing 
represented approximately ten percent of the total gross domestic product (GDP) with employment of eight to fourteen percent of the economically active population.

While the impact of the increased prices for traditional primary products was to create a sense of increasing prosperity, especially among the elite, it had little actual impact on the Central American economies. The increased import and export taxes, however, representing over sixty percent of the government revenues for the five countries, allowed a significant expansion of the public sectors. Thus a second significant trend emerged. That was a broadening of the ruling elite and the generation of a modified conception of the function of government. The "depression dictatorships" of the 1930s came to an end in a series of coups in the mid-1940s. A general sense among the expanded elite recognized a responsibility of government to deal with the problems of poverty within a democratic framework.

The public sector, then, began to support new central banks, increased public works, efforts at industrial and agricultural development and concerns for health, literacy and social security legislation. The values of the new elements of the ruling population are described as focusing on nationalism and economic growth within something of a democratic framework. ${ }^{4}$

It is particularly noteworthy that the frame of reference remained thoroughly nationalistic. As a result the political clashes between nations in the region were considerable. Many of the clashes involved intervention by regional or international agencies. At the same time, trade among the countries in the region was miniscule. It amounted to less than four percent of the imports from outside the region. The pattern of trade initiated during Spanish rule was still very much in place in 1950. All five

\footnotetext{
${ }^{4}$ Robert Lei: Weodward. Jr.. Cenlral Amurica: A Nation Divided. New York. Oxtord University Press. 1976, page 5. ff.
} 
countries had relatively well established transportation and communication links with the rest of the world but little with other countries of the region.

Some externally motivated projects, such as the Inter-American Highway, had been undertaken prior to 1950 , but they were unenthusiastically supported by the national governments. Regional orientation was weak and essentially motivated from outside the region, and aspirations for economic growth were uniformly seen strictly from within a national context as a function of external "free market" trade.

The United Nation's ECLA was one of those external forces which were attempting to motivate regional orientation. ECLA pushed a perspective which recognized a dichotomous division of world production. There were the industrialized "centers" of production (the developed nations) and the raw materials producing "peripheries" of production. The peripheral producers were understood to be dependent upon their export sectors for the importation of goods produced by the centers. The resulting dependency, it can be argued, represented a worsening situation in which the terms of trade have been historically moving against the peripheral producers.

ECLA's solution for this problem was for the peripheral countries to change the structure of their economic production. This was to take the form of industrialization in order to remove themselves from the dependent relationship in the context of world commerce. In Central America that required the establishment of a regional market to support the industrialization effort. A prime requirement of industrialized commerce was seen to be that it function in a larger market than any of the individual Central American nations could provide. Thus, a push for regional economic organization became integral to ECLA's programs in Central America.

The arguments and counter arguments regarding economic integration were rampant, varied and often loud. But the central message as presented by ECLA was 
one of the need to restructure the standing economic relationships. This implied considerable threat to the status quo within the nations, and between them as well. Therefore ECLA interpreted its task as that of organizing the process so that the national elites were not threatened, but instead were enticed by the potential in the program.

In June, 1951, ECLA's fourth annual conference was held in Mexico City. A program for the economic integration of Central America was proposed during the conference and a permanent regional office was established in Mexico City. This office was to become the base of operations for the integration program in Central America.

The Committee of Economic Cooperation, established at that time in Mexico City, consisted of the ministers of economic affairs of the five Central American nations supported by ECLA's technicians. The first meeting of the committee itself took place in Tegucigalpa, Honduras, in 1952. For several days the committee met and discussed cooperative planning for expanded markets and coordination of both agricultural and industrial production in the region. The separation of the committee from ODECA was made clear when the economic ministers, functioning as the Committee for Economic Cooperation, closed the ECLA conference on the fourth day. They then formally reconstituted themselves as ODECA'S Economic Council for a separate one day meeting. This precaution proved to be important to the continuity of the integration effort when Guatemala withdrew from ODECA in early 1954 claiming apparently correctly - that the other four participants had undertaken to support an overthrow of the current (Arbenz) regime in Guatemala. With Guatemala's withdrawl, ODECA became ineffective as a regional body for neariy three years.

ECLA'S Committee continued to function and produce considerable results. With the third regional conference in late 1954 the Committee had undertaken several 
specific projects in pursuit of regional integration. A school for public administration was to be established in Costa Rica, a standardization of customs nomenclature had been undertaken and plans for an industrial research institute and various specific industries were underway. By this time the 'technicos' of both ECLA and the individual nations were announcing to the press that they were "...paving the way toward political (as well as economic) unity." 5

Things continued in this manner until by 1957 the ministers had approved two key aspects of the integration program. They agreed on a Central American Free Trade Zone and on a system of regional industries which would have special privileges under the plan. The documents had been drawn up under the supervision of ECLA's technicians but they dealt only with basic aspects of the agreements. A separate five nation agreement would have to be signed regarding each industry to be included in the regional industries pact, along with individual negotiations on tariff reductions, tax exemptions, subsidies and fiscal benefits. This presented a cumbersome and perhaps even unrealistic prospect.

The Free Trade Zone was also initiated in minimal form. It was established on the basis of a limited number of items which were to be expanded over the coming years. The Committee announced in the first few days of 1959 that a Common Market had been created. Treaties had been ratified by the individual countries which formally established multilateral free trade and the Regime of Integration Industries. These two instruments published the acceptance of the five countries of ECLA'S original intent: that integration be a gradual process which was to be based on planned reciprocal industrialization.

By the time the treaties were signed, however, the five countries were giving clear indications of decreasing interest and disengagement from the process. The other

\footnotetext{
5 New York Times. November 2. 1954
} 
side of that attitude took the form of ECLA'S increasing frustration, leading to a push on the part of ECLA for more engagement by the participants.

From the beginning the costs to the governments were intentionally kept low by means of the United Nation's payment of most of the costs. The government contributions had been kept at a token $\$ 5,000$ per year while the United Nations' part of the package began at $\$ 90,000$ per year and reached $\$ 300,000$ by 1959 . These increases included the majority of the budgets for the School of Public Administration located in Costa Rica and the Institute of Industrial Technology in Guatemala, both of which were in full operation by 1959 .

In reality the "Common Market" which had been announced in 1959 consisted essentially of treaties in which it was agreed to sign further treaties. Commentators at the time felt that there was no meaningful consensus among the participants. By this time the process was being described on all sides as "slow and painful" with concern that no real accomplishment had yet been made.

The costs of the program had been increasing for some time. Finally the United Nations Technical Assistance Board denied some requests related to the integration project due to lack of availabe funds. In late 1959 the Committee proposed that some of the costs be picked up by the five governments. ${ }^{6}$ This meant that the national governments were to begin bearing costs for a regional project. At the same time ECLA began making it clear that it planned to reduce direct involvement in the project when the regional institutions created by the treaties began to become effective.

At this point the tecnicos within the five countries found their relatively passive support to be melting away. When the costs and commitments were negligible, they encountered little resistance. But now the governing elite were being asked to support the regional endeavor both financially and in terms of national structural change. Some

${ }^{6}$ Isaac Cohen Oranles, Regional Integration in Centrnl Ameriva, Lexington. Mass., Lexington Bowks, 1972. page 24. 
national prerogatives were to be given over to regional decisionmaking and they were facing the real possibility of short term national income loss in favor of long term regional gain.

ECLA's strategy for instituting the requisite change in Central America while at the same time enabling the comfortable engagemnt of the national elites was proving to be incapable of laying the foundation for solid structural change. The approach taken had involved the attempted separation of the economic program from the politics of the region, together with a gradual approach to integration which was intended to permit slow and relatively painless restructuring of the national economies. All this was to take place at minimum cost to the countries involved. But as a higher level commitment was asked on the part of the five participant countries, there developed a uniform loss of interest in the project.

By 1959 the outlook for the integration effort which was to have supported the structural change in the economies, was not bright in spite of the appearance of solid achievements. Of the five participants, El Salvador seems to have been the nation with the most active interest in realization of the project. A prime reason for this appears in the fact that although population increase in the context of decreasing availability of land was a common problem in Central America, El Salvador has long been recognized as the only country which is uniformly overpopulated. ${ }^{7}$ The regional effort would not only allow expanded markets, and hence expanded employment for El Salvador, but in the final analysis would be a direct solution to the excess population since one of the attributes of the Common Market was to have been the free flow of factors of production - including labor - within the Common Market area.

\footnotetext{
7 Roger D. Hansen. Central America: Rugional Integration and Economic Develonment. Washington D.C.. National Planning Association. 1967. page 12fr.
} 
El Salvador, then, had the most to lose as the integration effort lost momentum. By that time, however, another actor in the drama had made its presence known by expressing disfavor with the scheme. The United States stated its position clearly in several different forums in 1959. Early in the year, the conditions for U.S. support of Central American integration were stated in an Organization of American States (OAS) meeting in Washington. The key point made by the U.S. negotiators was that the theoretical context would have to be that established in the early 1950 's analysis of Customs Unions by Jacob Viner. ${ }^{8}$

Viner's theoretical position required that policy be made on the basis of the static, neoclassical analysis which emphasized world-wide efficiency of resource allocation and strictly free market decisionmaking. This meant that the Regime on Integration Industries, a central element of ECLA's perspective, an element which involved considerable market intervention, would have to go.

Three months later, at the ECLA conference in Panama, the U.S. announced that it would support the creation of a "realistic Latin American regional market."9 That is, one in which there were no major exceptions to a free market policy for the benefit of preferred interests. Any alternative, it was stated, would discourage competion and reduce efficiency. The New York Times explained the U.S. concern that anything more restrictive than an open, free market arrangement would discriminate against U.S. product in favor of goods manufactured within the regional market area.

That discrimination, however, was exactly what ECLA had had in mind. The motivating force for the effort was the perception of a need to industrialize the region.

8 James D. Cuchrane. "U.S. Attitudes Toward Central American Integration". Inler American Economic Affairs, V. 18, 1964. page 75.

9 New York Times. May 17, 1959. 
The major means of accomplishing that, from ECLA's point of view, involved the protection of local industry against that of the already industrialized parts of the world.

In the spring of 1959 , Jose Maria Lemus of El Salvador traveled to Washington, D.C. with the intention of discussing Central American integration. The talks focused on the need to re-invigorate the process and on the need for the integration scheme to meet U.S. requirements. Ultimately a joint announcement was made by President Lemus and President Dwight Eisenhower that the two countries would undertake "The establishment of an economically sound system for the integration of the economies of the Central American republics. 10

A few months later a mission from the United States traveled to Central America to assist in the establishment of such a sound system. By early the following year the New York Times announced that ECLA had called an extraordinary session of the Economic Cooperation Committee. The purpose was to prevent the threatened collapse of the Central American integration program. Three months earlier a threeparty free trade pact which undercut the ECLA program had been signed under the sponsorship of the United States. ${ }^{11}$ The U.S. Mission had culminated in an agreement by El Salvador, Honduras and Guatemala to form a free trade area based on the principles set forth earlier in the year.

By the close of the session ECLA had regained some involvement in the process by means of negotiating a new treaty which incorporated the three-party pact. What is now known as the General Treaty of Central American Integration was initiated and finally signed by four of the five countries in December 1960. Costa Rica ultimately signed on in 1962. The new treaty, however, represented a major turn away from the ECLA inspired approach and toward that required by the U.S. The establishment of

\footnotetext{
10 Roger D. Hansen. op. cit.. page 27.

II New York Times, May 1. 1960.
} 
free trade in the region was accelerated and the core effort was reoriented from prime concern for industrialization to prime concern for free trade expansion. Aside from the fact that the elite in the five nations showed no signs of intention to support the regional industrialization plan, this represented a key decision to support growth rather than development and structural change in the region. Financial involvement by the United States which took the form of support for the regional institutions necessary to the effort, was a major ingredient in the renewal of the integration effort. This constituted a program of growth rather than development and structural change in the region.

The United States had committed itself to support the project at the rate of at least ten million dollars in the first two years. Thereby the participants were relieved of any concern for making significant financial commitments themselves. An even more important element in the new approach, an element which encouraged enthusiastic engagement by the governing elite in the five countries, was that the new theoretical approach promised no threat to the economic structure in Central America. Yet it carried the possibility of significant increase in economic activity.

That the United States underwrote the creation of a regional bank and a financial clearing house and vehemently opposed the Integration Industries plan is entirely in keeping with the theoretical position which had been established. Neoclassical orthodoxy requires that there be no direct intervention in market-place decisions. Hence, industrial planning for the purpose of generating structural change, as intended by ECLA, was not to be tolerated. Instead, growth was to be enouraged through the availability of funds to the capital market.

The Integration Industries plan became an underlying theme of U.S. involvement in the region for the next three years. It had been incorporated into the General Treaty in 1960 in response to ECLA's urging and, contrary to the disagreement on the part of the U.S., its implememtation continued to be encouraged 
be ECLA. Finally in 1963 El Salvador proposed, and the Executive Council for the Treaty accepted, the Special System for the Promotion of Industrial Activities. This modification effectively undercut the Integration Industries plan and foreign private investment gained a broad entry into the region. 12

At that point the role of external motivator and financial supporter of the integration effort had been entirely assumed by the United Sates. As a result, the five participant countries continued to be relieved of both financial responsibility and serious decisionmaking with respect to the project. This role on the part of the five nations is entirely consistent with the historic one described earlier. The control of the Central American leadership had long depended upon the involvement in Central America of foreign interests and, as restructured according to U.S. principles, there was nothing in the form of the integratation plan to threaten that arrangement.

In early 1964 the five Central Bank Presidents signed an "Agreement for the establishment of a Central American Monetary Union." The Union was to provide the means for avoiding unilateral action in case of balance of payments problems. As it was being set up, however, falling world prices for coffee, cotton and bananas put considerable stress on the individual countries in the form of decreasing export revenues with increasing third country (outside the region) import bills. Some of the five were also experiencing sizeable increases in imports from within the region. Costa Rica and Nicaragua undertook unilateral solutions which moved their national crises into the regional realm by threatening the regional agreements. In mid- 1968 the Economic Council and the Monetary Council met in a joint session and developed "Emergency Measures in Defense of the Balance of Payments." Those measures came

12 William R. Cline and Enrique Delgado. Economic Integration in Central America. Wasthington. The Brookings Institution, 1978, page 32r. Also see Roger D. Hansen. op. cit., and James D. Cochrane, op. cit.. 
to be known as the San Jose Protocal and were intended as an interim solution to a long range problem.

The Protocol was widely seen as an important turn toward more serious regional cooperation to solve national problems. But some observers suggested that the revenue problems being encountered in the individual nations could more easily have been solved by raising income taxes, tightening up on fiscal incentives for industry, levying property taxes and similar internal measures. Seen from this perspective, the San Jose Protocol appears to represent the desire to avoid the domestic political consequences of dealing with national problems by forcing the problems into the regional level.

In the final analysis the 'tecnicos' who assembled the protocol, in a now familiar mode, endeavored to avoid political costs to the member countries. National executives were given the authority to grant exemptioms from the third country import tax to firms in industries of particular importance to the economic development of the region and to firms which would suffer greatly from its application. Also, the consumption tax on luxury items was to be optional and the national customs agencies were to be responsible for the administration of the taxes. One writer commented that the measures were traditional responses to fiscal and balance of payments problems. They were responses which required no change in economic structures nor did they require any surrender of national authority. 13

Enrique Delgado of the Integration Treaty Secretariat describes the seventeenth meeting of the Economic Council of the Treaty earlier in 1969 as one which adopted resolutions which "were perhaps the most comprehensive attempts made to date to find an answer to the increasing problems of integration. It was within this spirit of joint

\footnotetext{
13 Royce Q. Shaw, Cemtral America: Regpional Inlegmation and National Political Develonment. Boulder. Colorado. Westview Press. 1978. page 90.
} 
effort that the solutions to the overall problems posed appeared to be imminent when on July 14, 1969 armed conflict broke out between (Honduras and El Salvador). "14

The ensuing political and economic disruption was all but fatal to the Common Market in Central America . Honduras disallowed Salvadorean use of the Pan American Highway through Honduras, effectively cutting the region geographically in half. As Delgado put it in 1978, Central Americans "...have waited anxiously for resumption of full relations (between the two countries), " but it was not until ate 1980 that a peace treaty was signed. The borders were reopened and the two countries finally committed themselves to a reactivation of the Common Market. 15

In the meantime the news sources reported meeting after meeting of the Economic Ministers in attempt to negotiate agreements and reorganizations of the Common Market. In December 1969, Facts on File reported an agreement of the five ministers to "continue trying to rebuild the Central American Common Market...". That meeting had ended with agreement by the Normalizing Commission on a "temporary 'Modus Operandi' " which was to apply until the confict between Honduras and El Salvador was settled. ${ }^{16}$ The 'Modus Operandi' failed almost immediately when Honduras set new unilteral tariffs with the other CACM nations.

Through the 1970's more problems emerged. Costa Rica, for example, withdrew from the Automatic Payments System due to its large international debt. Ultimately a short-range solution - a devaluation - was agreed upon by the other four members of the Common Market. Similar problems were encountered and dispensed with by means of short-term, patchwork responses. The responses appeared to address

\footnotetext{
14 William R. Cline and Enrique Delgado, Economic Integration in Central America, Washington. The Bmokings Institution, 1978, page 41 .

15 Keesings Report. January 31. 1981.

${ }^{16}$ Facts on File. December 31, 1970.
} 
the immediate problem but invariably avoided the clear need for structural adjustments in the regional economy. Indeed, not unlike the pattern with the international economic system as a whole, the Common Market underwent one short-term solution after another as the Economic Ministers continued to meet to seek "normalization" and "temporary arrangements."

An important characteristic of the history of post-World War II Central America is the firm stability of two key institutions in the region. The first, the strictly national basis for political decisions has stood unscathed and, the second, the national governing elites (with the temporary exception of Nicaragua) have maintained a tight control on the governments in spite of pressure to expand access to the political and economic resources.

Royce Q. Shaw, writing on the politics of the region in 1978, pointed out that:

The traditional pattern of elite socialization in Central America has been reinforced by the successful cooptation of the two recent marginal elites to emerge in the post-war era, the industrialists and the 'tecnicos'. Like the agricultural exporters who preceded them, (in the latter 19th and early 20th centuries) the industrialists and the 'tecnicos' used external assistance as a source of power with-which they could bargain for a position in the political hierarchy." 17

One of the 'tecnicos', Eduardo Lizano of Costa Rica wrote in 1975 of the built-in problems with the Central American Common Market. Central America, he says, is notably lacking in regional institutions, and yet, unlike the case of the European Economic Community, there was no provision for gradual institutional changes toward an effective supranational organization. This readily coincides with the points made by others regarding the role of the political elite. Clearly there was no intention on the part of the elite in those countries to relinquish any aspect of their control to a

\footnotetext{
17 Royce Q. Shaw. Centrnl America: Regional Inlegralion and National Political Develonment. Boulder. Colorado. Westview Press, 1978, page 228.
} 
supranational agency. ${ }^{18}$ The centuries-old pattern of local rule in the interests of a small elite and in the context of foreign domination of the economies, remained unbroken.

Lizano goes on to describe several groups which originally supported the effort but "lost faith" in the program. The industrialists, he suggests, exhausted the easy pickings. The 'tecnicos' quickly gave up their roles as agents of change and became agents of the status quo. The national bureaucrats who were early supporters found themselves faced with problems they were not prepared to deal with. And the intellectuals saw the emergence of increased rather than decreased economic dependency. They turned against the CACM, then as merely another opportunity for international capitalism to dominate the underdeveloped countries. In conclusion he states that "Political power in each country tends to be vested in a relatively small group of persons who rule in their own self-interest rather than in the interest of a broad electorate." 19 In view of that, he concludes, real integration depends on social and political change in each member country.

It is not difficult to conclude that the leadership in Central America had neither the capacity nor the desire to cause change in the economic realm. The effort was focused on growth without the structural transformation which was clearly intended in the ECLA plan.

The recent history of economic policy for the region is shown in Figure 5-1. Though specific policy decisions differed among the five Central American nations, both the character and the political ambience for the decisions were sufficiently

\footnotetext{
18 Eduardo Lizano and L. N. Wilmore. "Second Thoughts on Central America: The Rosenthal Report". Journal of Common Market Siudies. Vol. 13. Number 3. 1975.

19 Gary W. Wynin. Politics and Planners: Economic Develonment Policy in Cenmral Ambricn. Madismn. University of Wisconsin Press. 1972. page 306.
} 
consistent that it is appropriate to treat them as a unit. All five nations have been primary goods exporters since the colonial period.

The dominant policy of simple economic growth through expansion of agricultural exports has been essentially unchanged for centuries. In the twentieth century, as can be seen in Figure 2, the pursuit of growth through agricultural exports remained dominant. Economic expansion in the twentieth century took place in the form of increasing agricultural output, not through the restructuring of the domestic economy such as is anticipated in the Kuznetsian process of modern economic growth.

The only effort to undertake development is to be seen in the ECLA-driven phase of the CACM project. By the time the CACM had been instituted, however, in the early 1960 s, the combination of U.S. dominance and elite disinterest, assured the the plan was stripped of any capacity to promote change.

The import substitution plan was squelched at U.S. insistence in 1959. That limited the potential for internal management of the Central American economies. An important step in the development process which was pursued by the ENICs was disallowed the policymakers in Central America. The U.S. and Central American elite insistence on unfettered free trade in the region, meant a continuation of unlimited foreign involvement in the five economies. The nominal 'import substitution' phase, coinciding with the existence of the Central American Common Market, was used as an opportunity for private plunder rather than as an opportunity to strengthen the national economies. Policy took the form of encouraging investment for any purpose, from any source, not of developing productive capacity in the domestic economies themselves.

Specifically, the maintenance of a profitable environment for investment involved permanently low interest rates, permanently overvalued currencies and permanent repression of labor. These became not so much policies, then, but exploitative devices. The failure to develop under these circumstances appears to be as 
much a function of weak governments faced with foreign domination as of lack of intention on the part of the Central American governments.

\begin{tabular}{|l|l|}
\hline POLICY EVOLUTION DURING THE PERIOD OF GROWTH AND DECLINE \\
\hline 1900 & Primary Export-Led Growth - Focused exclusively on \\
to & coffee and bananas as revenue for government \\
1950 & and for import of manufactured and luxury goods. \\
\hline 1951 & Expanded Primary Export-Led Growth -Diversification \\
to & of agricultural exports to include cotton, sugar \\
1959 & and beef as well as coffee and bananas. \\
\hline 1960 & Grafting of Regional Import Substitution through \\
1961 & the Central American Common Market to Primary \\
1962 & Export-Led Growth. The policy incorporated: \\
1963 & -U.S. pressure for 'pure market' way to growth. \\
1964 & -Rejection of the UN-ECLA scheme for planned \\
1965 & regional import substitution. \\
1966 & -Overvaluation of all currencies. \\
1967 & -Low interest rates. \\
1968 & -Selective regional tariffs. \\
1969 & -Push for technology-intensve capital imports \\
1970 & -Violent repression of labor demands. \\
1971 & -Gradual withdrawl by nations from CACM. \\
1972 & -Foreign, international market, controlled \\
1973 & allocation of financial resources. \\
\hline 1974 & Disintegration of Central American Common Market. \\
1975 & -National policies adopting 'non-traditional' \\
1976 & primary exports. \\
1977 & -Free trade zones, intra-regional competition \\
1978 & for external markets, reduction of \\
1979 & investment in infrastructure \& education. \\
1980 & -Increased U.S. support of "stability" of CANs. \\
\hline 1981 & Official demise of Central American Common Market. \\
1982 & -Shift from regional market focus completed. \\
1983 & -National policies of flexible exchange rates, \\
1984 & dismantled protective structures, \\
1985 & encouragemnt of direct foreign investment, \\
1986 & continued real-wage 'discipline'. \\
1987 & -Abandonment of token investment in education \\
1988 & health projects and rural infrastructure. \\
1989 & -Increased U.S. support for "stability". \\
1990 & -Violent repression of 'unrest'. \\
\hline
\end{tabular}

Figure 2. Policy Record for the Central American Nations. 


\section{AFTER THE ILLUSION}

Victor Bulmer Thomas describes the early period of CACM as "the illusion of a golden age." "By conventional measures of economic progress the decade of the 1960s was a golden age for Central America. The reality of the decade was somewhat different. "20 A substantial part of the problem, says Torres-Rivas, was the failure to create internal demand. "The only sector of the population which created a demand for industrial goods was a small minority of people closely linked to foreign capital who received a part of its benefits. At the other end of the scale was an over-abundant labor force with wage levels so low as to seriously inhibit the formation of an internal market. In this case the 'wage earner' was not a consumer." 21

What industrialization there was took place according to an 'import substitution model' which focused production on consumer goods for immediate consumptiom. It did so by substituting some imports for others without reducing the overall import coefficient. The permanent Secretariat for the CACM (SIECA) published import figures for 1970 for the five nations which showed the total imports of capital goods at 95 to $98.6 \%$ from outside the CACM for the five nations. The imports of raw materials ranged between 75 and $80 \% .22$

As Torres-Rivas describes it, industrial activity was built around "the processing of local raw materials or the finishing of consumer goods partially processed abroad all with imported caital." Foreign control left little opportunity for the assimilation of

\footnotetext{
${ }^{20}$ Victor Bulmer-Thonas. The Political Economy of Central America Since 1920. Cambridge, Cambridge University Press, 1987, page 175.

21 Edelberto Torres-Rivas, "The Central American Model of Growth: Crisis for Whom". Lnlin American Persinectives, Vol. VII, 1980, page 28.

22 Victor Bulmer-Thomas, The Political Economy of Central America Since 1920. Cambridge. Cambridge University Press, 1987, page 193.
} 
new technologies or for local entrepreneural engagement. The local role tended to be reduced to that of administrator for foreign capital. 23

The result of the decisions made regarding the growth model in the late 1950's and early 1960's was the dramatic increase in foreign investment on one hand and persistence of a high import coefficient on the other, says Torres-Rivas. And that accounts as well for another of the problems resulting from the growth effort, the crippling size of the foreign debt.

The Central American Common Market effort has been criticised for many specific failures. Bulmer-Thomas cites "the unbalanced way that benefits were distributed to member countries, the unmanaged penetration by multinational companies, the poor employment record and," most importantly, "the failure to break the dominance of traditional exports and of the agro-export model." 24 What he does not mention in that article, though many other commentators do, is the observation that any 'growth' project which ignored the internal market was not likely to succeed over time. As Torres-Rivas stated it, "We all know that the market is composed of solvent consumers, not citizens. Of eighteen million of the latter only two million have the option of participating in the market". 25

\footnotetext{
23 Edelberto Torres-Rivas, "The Central American Model of Growth: Crisis for Whom", Latin American Perspectives. Vol. VII, 1980, page 30 .

24 Victor Bulmer Thomas, "The Economics of Central America", Latin American Research Review, Vol. XXIII, Number 3, 1988, page 156.

25 Edelberto Torres-Rivas, "The Central American Model of Growth: Crisis for Whom", Latin American Perspectives, Vol. VII, 1980, page 43.
} 


\section{CHAPTER VII}

\section{TAIWAN AND SOUTH KOREA: THE POST-WORLD WAR II PERIOD}

\section{THE HISTORICAL BASIS}

In a recent article on the development history of Taiwan and South Korea, as well as Japan, Paul Kuznets suggests several noneconomic characteristics of the ENICs (Taiwan and South Korea) which underlie the post-World War II LDC development experience. Both are characterized by ethnic and linguistic homogeneity, relatively compact geography, substantial but manageable population size, and a Confucian tradition. ${ }^{1}$ There are other comparable aspects. Both countries have a history of colonial occupation, the most recent, pre-World War Il, period of which involved the Japanese. Both were also relatively agriculturally dominated until shortly after World War II and neither are particularly well endowed with natural resources.

The legacy of Japanese occupation is often cited as an important basis for development from underdeveloped status for the two nations. On the other hand, such comments are usually accompanied by cautions that the occupation left the two countries with the typical colonial legacy of disruption and dependency. L.L. Wade and B.S. Kim describe the legacy in Korea. "The nation's human resources had been left undeveloped by the Japanese and the interconnected industry and infrastructure built during Japanese rule - always oriented toward Japanese rule in any case - was severed by the partition of the nation at the 38th parallel when the United States and the

\footnotetext{
1 Paul W. Kuznets. "The East Asian Model of Economic Development: Japan. Taiwan and South Korea". Economic Develonment and Cultural Change. Vol. 36. Number 3. April 1988. page 335.
} 
new Soviet Union were unable to agree on the basis for a new Korean polity following the Second World War". 2

The disruption of the trade with Japan and the inexperience in political and economic leadership are described as important obstacles for South Korea, contributing to the "pervasive distress of the (immediate post-World War) period". Some economic progress was made, however, "only to be largely destroyed during the Korean war of 1950-53". Through the 1950s South Korea's was seen by writers as one of the lesser promising underdeveloped economies on the global scene. Larry Westphal, writing in 1990 states that "Observers of the Korean economy in the late 1950s did not expect it to become one of the world's most dynamic. Quite the contrary, it was considered something of a basket case." 3

In the case of Taiwan the investment and resource flows are said to have been typical of a colonized country. The colony supplied Japan with primary products, particularly sugar and rice, and Japan supplied the colony with manufactured consumer goods. According to one study, "Until the Second World War altered Japanese priorities, there was little encouragement of domestic industry beyond the processing of agricultural goods for export and the construction and operation of utilities required to support this processing." 4

As with South Korea, both the Second World War and the succeeding several years brought considerable destruction to Taiwan. The island was subjected to heavy American bombing during the war. The bombing is described as having destroyed

\footnotetext{
2 L.L. Wade and B.S. Kim. Economic Develonmenl of South Konea, New York. Praceger Publishers. 1978. page 30.

${ }^{3}$ Larry E. Westphal, "Industrial Policy in an Export-Propelled Economy: Lessons from South Korea's Experience". Journal of Econonic Persnectives. Vol. 4, Number 3. Sumuner, 1990. page 42.

4 John C.H. Fei, Gustav Ranis and Shirley W.Y. Kuo. Growh with Equitv: The Taiwan Case. New York, Oxford University Press, published for The World Bank. 1979, page 22.
} 
"three-quarters of the industrial capacity, two-thirds of power, and one half of the transport network. "5

At the same time, of course, the Japanese evacuation of the island left it without the administrative and economic leadership of the preceding fifty years. The external economic connections were also severed. Previously dependent on Japan for its external markets, the newly liberated island found itself attached to the Chinese mainland.

This did not represent improvement in the fortunes of the island. Although Taiwan was not directly involved in the Chinese civil war, the Nationalist regime, the Kuo Min Tang (KMT), which was eventually to seek asylum there, used the island as a source for resources. Both factories and raw materials were gathered and shipped to the mainland to be used in the battle with the Communist forces. Calvin Clark describes the post-World War II production level in Taiwan (depending upon the particular product) to range between $25 \%$ and $50 \%$ of pre-World War II levels. The production of sugar was reported to have been $6 \%$ of the pre-war level in a 1973 study. 6

As with Korea, Taiwan entered the 1950s as a less than impressive prospect for economic development. Taiwan is described as facing "a rather bleak situation at the time of the R.O.C.'s evacuation to the island in $1949 .{ }^{7}$ In spite of the unlikely prospects, however, something of a base had been laid by the Japanese colonizers, and in the case of Taiwan the evacuation from the mainland brought substantial advantages.

\footnotetext{
5 Gustav Ranis, "Industrial Development", in Walter Galenson. ed., Economic Growth and SIructural Change in Taiwan: The Postwar Exnerience of the Renuhlic of Ching. Ithaca New York. Cornell University Press. 1979. page 209.

6 Cal Clark. Toiwan's Development: Implications for Conlending Political Economy Paradigms. New York. Greenwood Press, 1989, page 61. The 1973 study is Anthony Y.C. Koo. "Economic Development of Taiwan". in Paul K.T. Sih, ed., Taiwan in Modern Times, New York. St John's University Press. 1973, page 402.

7 Cal Clark, op. cit., page 75.
} 
Among the KMT leadership were "skilled administrators and entrepreneurs who could fill the void left by Japanese exclusion of the Taiwanese from these fields. The party, in addition, was based on a strongly developmentalist ideology committed to nationalism, democracy and people's livelihood. ${ }^{8}$

\section{FREE MARKETS AND GOVERNMENT INTERVENTION}

Both Taiwan and South Korea started the development process in the 1950s with prospects that were less than glowing. Yet by the last decade of the century it has become clear that the effort to transform the economies was not only dramatically successful, it was done while maintaining a high level of stability, and in the context of a level of distribution equity which is very high.

In a 1979 study Fei, Ranis and Kuo described income equality in Taiwan as among the highest in the world with Gini coefficients of .289 before taxes and .285 after taxes. ${ }^{9}$ A comparable study in South Korea found the Gini coefficient for 1970 to be .332 , and .389 for $1980 .{ }^{10}$ Though the numbers for Korea are higher than those for Taiwan - therefore the distribution equity is not as high - they still place South Korea among the high equity nations in the world. ${ }^{11}$

Both countries have been the subject of a number of studies geared to the evaluation of government involvement in the development process. In both cases government played a substantial role in the process but the methods of development

\footnotetext{
8 Cal Clark, op. cit.. page 76.

9 John C.H. Fei. Gustov Ranis and Shirley W.Y. Kuo, op. cil.. The Gini coefficients. from a 1978 study, are cited in Shirley W.Y. Kuo. Gustav Ranis and John C.H. Fei. The Taiwan Success Story, Boulder, Westview Press, 1981, page 140.

10 Hagen Koo, "The Political Econony of Income Distribution in South Korea: The Impact of the Stale's Industrialization policies", World Deveionminn, Vol. 12. October, 1984, page 1030.

11 The. Gini coefficient is the ratio of the area between the Lorenz curve (the plotled distribution line) and the perfect distribution line, to the area below the Lorenz curve.
} 
support differed substantially between the two. It is generally recognized that the fact that both were successful in the endeavor suggests that the source of the success is to be found in something other than the specific policy decisions made by each country. 12 The success, in other words, is recognized to be more a function of the dynamic intervention and management of the developing economies than of any particular policies. Generally, whereas the government of Taiwan has tended toward a guiding and supportive type of function, the South Korean government has been collaborative and even coercive in its relationship with the private sector.

Both engaged in import substitution type policies in the 1950s, and both switched to managed export-led development policies in the next decade. Export-led development is to be distinguished from export-led growth primarily in terms of the policy relationship to comparative advantage. An Export-led growth approach assumes a static relationship to comparative advantage and recognizes only its present status. Export-led development, on the other hand, as exemplified by Taiwan and South Korea, recognizes comparative advantage as a dynamic phenomenon. In this approach the present state of the economy provides the resources which are to be managed in order to build a technically and organizationally more complex level of comparative advantage. This is represented in the stages of policy evolution since the 1950 s in the two ENICs as shown in Figure 6-1 at the end of this chapter.

It is clear that regardless of how politically and economically stormy the initial phase was for both countries, it provided the necessary foundation in both cases for the export-led phase which followed. In the case of South Korea, policymaking in the 1950 s was a function of the apparent inability of the economy to generate adequate

\footnotetext{
12 Some of the studies include Paul W. Kuznets. op. cit.: L.L. Wade and B.S. Kim. op. cit.: Larry E. Wesiphal. op. cit.; Larry E. Westphal, op. cit.; Gustav Ranis, op. cit.: Hagen Kon, op. cit.: John C.H. Fet. Gustav Ranis and Shirley W.Y. Kuo, op. cit.; and H. Pack and L.E. Westphal. "Industrial Siralegy and Technological Change: Theory Versus Reality". Journal of Development Reality, Vol. 22, 1986. pages 87-128.
} 
levels of exports and savings. Because the economy was expected to remain in a dependent status for the foreseeable future, policymakers tended to reinforce that status. They saw their function as the management of imports together with the solicitation of foreign aid to balance against the imports.

These concerns in Korea were consistent with the former colonial function of the economy, but they were also consistent with the import substitution phase of the development effort, which, with the correct policy mix, was geared to building the internal economy. Foreign trade per se was discouraged through policies of currency overvaluation, high tariffs and quantitative import restrictions. Each of these policies were geared to encourage import substitution and discouraged exportation.

Pack and Westphal describe the period of the 1950s as one in which the industrial base grew at a respectable rate due to the import substitution encouraged investments in light manufactured and non-durable goods. Even more importantly, they suggest, the "human capital stock was greatly augmented through major programs that instituted universal primary education and achieved nearly universal adult literacy." 13 The institutions of higher education were also expanded and large numbers of students were trained abroad in technical specialties. It is clear that by the time of the policy shifts to export-led development in the early 1960s, South Korea had created a comparatively strong industrial base of both physical and human capital.

In Taiwan, as well, the 1950 s were a period of early transition toward industrialization. Fei, Ranis and Kuo describe the period as one characterized by the diversion of traditional export proceeds away from expansion of the colonial enclave and toward investment intended to replace previously imported industrial consumer goods by domestically produced consumer goods. As with Korea, they undertook

\footnotetext{
${ }^{13}$ H. Pack and L.E. Westphal. "Industrial Stralegy and Technological Change: Theory Vursus Reality". Journal of Development Reality. Vol. 22. 1986. page 92.
} 
classic import substitution. But, also as with Korea, what is important to the question of transition toward modern economic growth is that the allocation of the resources was intentionally redirected in keeping with the perception of comparative advantage for the nation.

In keeping with the policy decisions in Korea, the Taiwanese opted to invest heavily in the population of the nation as the basis for the development effort. K.T. Li describes the agricultural, human resources and manpower policies of the 1950s as key to the later success of the transition. ${ }^{14}$ Much of the human resources and manpower efforts of the 1950s was focused on education. The success in that realm can be seen in the data described in chapter 9 of this study. By 1960 slightly over $95 \%$ of school aged children were enrolled in primary schools and $43 \%$ of the high school graduates were enrolled in schools of higher education. 15

Superficially the early policy measures in Taiwan were typical of an import substitution effort. Overvalued exchange rates, import restrictions and deficit government financing were all used. But as Fei, Ranis and Kuo point out, "Close examination reveals substantial differences from the classic (policy mix)". 16 Agriculture received, for example, supportive attention during the period in the form of major land reform and investment allocated to rural infrastructure. As a result of the attention, the terms of trade for the agricultural sector dropped very little by the end of the 1950s from the figures established in 1952. Interest rates as well were kept much higher than is typical for an import substitution effort. As a result, savings were

\footnotetext{
14 K.T. Li, The Evolution of Policy huhind Taiwan's Development Success. New Haven. Yale University Press. 1988. page 105.

15 Taiwan Statistical Data Book. Republic Or China, Council for Economic Planning and Development, 1990. Table 14-8, page 286.

16 John C.H. Fei, Gustav Ranis and Shirley W.Y. Kuo. op. cil.. page 27.
} 
encouraged at a much higher rate than is typical and, it is claimed, resource allocation was more appropriate to the later phases of the transition.

The success of the early phase in Taiwan is dramatically illustrated in the data of the period. Through 1961, despite population growth the real per capita income increased at nearly $3 \%$ per year, nonagricultural output increased at $8.7 \%$ per year, agricultural output increased at $5.5 \%$ and savings stayed in the $10 \%$ range. The industrial policy was geared to what was understood to be an important comparative advantage in Taiwan, the creation of labor intensive industry. And foreign capital, especially U.S. aid, was rigorously devoted to the purchase of overhead capital and industrial producer goods.

That a program like that of either Taiwan or South Korea differs considerably from that which characterized the Central American countries can be dramatically illustrated in the income distribution data mentioned in the previous section of this chapter. The data show the Gini coefficient for income distribution in both countries to be improving rapidly during the first decade of the development effort. For Taiwan, in 1953 the coefficient was calculated to be over .55. By 1959 the figure had dropped to .44 , and by 1964 it was approximately .32 .17

In both of the Eastern Newly Industrializing countries (ENICs) the turn toward export-led development occurred in the early 1960s. The methods used in each case, however, provide a lesson in contrasts. During the import substitution phase the Korean government began intervening directly in the allocation of resources. A substantial bureaucracy was created for the purpose. It controls the means for plan implementation, including industrial targets, market protection and loan guarantees, even issuing permits of entry for many industries.

17 John C.H. Fei, Gustav Ranis and Shirley W.Y. Kuo. op. cit., page 35. 
Taiwan, on the other hand, uses an indicative planning approach which takes the form of macroeconomic targets and sectoral investment plans. Planners have little direct authority and limited access to the policy instruments. Unlike South Korea, in Taiwan there is little linkage between the private realm of the economy and the economic planners. The Taiwanese government expects to encourage private activities in its policy interventions, confining direct interventions to the provision of social and physical infrastructure, for example.

In a paper presented at a recent American Economic Association conference, Yung Chul Park evaluates the two approaches to development as models for other national development projects. ${ }^{18} \mathrm{He}$ is critical of both efforts from the point of view of their inflexibility as new challenges appeared. Any such new development effort continuously creates new challenges as it proceeds through the transition process. At the same time it is necessary to respond to the global economic and political challenges which emerge over time. Park observes that while both efforts were clearly successful in the long run, one of the lessons to be learned from the endeavors is the need for the governments to be flexible with respect to their roles in the economy as a whole. In both cases, Park observes, the governments made their largest errors in persisting longer than was desirable in the chosen role with respect to their economies.

Park reports that the leadership in Taiwan were convinced that the concentration of resources on the mainland was one of the reasons for the Nationalists downfall. Therefore they were motivated to avoid such concentration on Taiwan. Regardless of the explanation, the Taiwanese leadership promoted an indirect role for government in the economy with the effort in the private sector focused on development of a large number of small and medium size firms. As recently as 1986 the data shows that $98 \%$

\footnotetext{
18 Yung Chul Park. "Development Lessons from Asia: The Role of Government in Sruth Korea and Taiwan". The American Economic Review - Papers and Procetedings. Vol. 80. Number 2. May 1990. pages 118-122.
} 
of Taiwan's firms employed fewer than 300 people, and $48 \%$ employed no more than 5 workers.

This approach created a resilience in the economy of Taiwan which goes a long way toward accounting for the ability to weather external shocks which show much more clearly in the aggregate data for South Korea, for example, than in that of Taiwan. The economic leadership in Taiwan promoted a high rate of savings throughout the transition effort, they took a conservative position with respect to fiscal and monetary policy and they generated ongoing trade surpluses from the time of the shift to the export focus on policy.

Park felt that the role-related problem for the Taiwanese emerged in the 1970 s when the development intentions shifted toward large scale, technology intensive export production. At that time "Entrepreneurs were unable and unwilling to make large capital investments with a long gestation period. Neither did the government have an industrial policy regime capable of planning and implementing an import substitution plan (for large capital and intermediate goods) as ambitious as Korea's." 19

Others feel that such concerns about the Taiwanese development efforts represent much ado about very little. Jan Hogendorn wrote respectfully of both the South Korean and the Taiwanese development efforts, saying that "By and large Taiwan made even fewer mistakes than South Korea. "20 Specifically, with respect to the encouragement of large capital investment, Hogendorn states that it is hard to argue with the record which shows manufactured goods exports increasing at "just under $30 \%$ per year from 1965 to 1981 and $21 \%$ even in the 'slow' year, 1984." The ratio of total exports to GNP in the mid 1980s was approximately 55\%, "the highest figure in the

\footnotetext{
19 Yung Chul Park, op. cit., page 120.

20 Jan S. Hogendorn, Economic Development. New York. Harper and Row, 1987. page 58 and 59.
} 
world among LDCs of any size, and of these (exports), about $40 \%$ are now heavy industrial goods." 21

The role-related problem which Park, a professor of economics at Korean University in Seoul, has with the South Korean approach to development is probably more convincing. Certainly the costs are more obvious. Unlike in Taiwan, the policymakers were faced with an array of structural and institutional problems as the shift to export expansion was taking place in the 1960s. Foreign lending became increasingly important in South Korea, rather than less so as it had for Taiwan at the similar point of policy shift. A low savings rate and chronic current account deficits made Korean government guarenteed foreign loans necessary.

At the same time, a perceived shortage of administrators and entrepreneurs led government decisionmakers toward centralization of national economic administration and toward industrial concentration. The decisions to concentrate on "increasing returns technologies...forced the government to support a few, selected large producers in targeted industries. "22 Both domestic and foreign savings were channeled to the resultant large firms through the banking system. The government assumed something of the role of a partnership with these firms, which came to dominate the manufacturing sector.

Park feels that although the government support was necessary during the early period of export development, the government intervention was not. The interventionist role led the government to establish a large import substitution program for capital and technology intensive products in the 1970s. This was a time, Park suggests, when deregulation of the controlled sectors should have taken place. Instead, the South Korean Policymakers chose to tighten the grip on manufacturing industries

\footnotetext{
21 Jan S. Hogendorn. op. cil..

22 Yung Chul Park. op. cit.. page 118.
} 
and financial intermediaries. Besides causing a worsening of the distribution equity mentioned above, the Gini coefficient increased from .332 in 1970 to .389 in 1980, the government had become responsible for the failures as well as the successes of the industrial endeavors.

The resultant excessive risk taking on a large scale, and the low export earnings and heavy losses which followed, Park observes, was a function of the policymakers inability to back away from the controlled sectors, allowing decisionmaking to take place on a more realistic global basis. Though some trade and financial liberalization took place in the 1980s Park describes the policy regime in South Korea as decidedly based on "development mercantilism". The government has still not been able to extricate itself from its tightly bound relationship with the industrial groups.

Though the manner of government involvement in the two transitioning economies were dramatically different, there is little doubt that the government contribution to rapid industrialization was substantial. Pack and Westphal conclude in their extensive 1986 study that "market forces alone are not responsible for the purported 'market successes' of the East Asian NICs" 23 The authors cite a comment by Tibor Scitovsky which neatly summarizes a key argument for them, and also sheds considerable light on the role of government in the development process. Scitovsky states that "Market prices...reflect the economic situation as it is and not as it will be. For this reason they are more useful for coordinating current production decisions...than they are for coordinating investment decisions, which....should be governed...by what the future economic situation is expected to be. In underdeveloped countries...investment is likely to have a greater impact on prices, give rise to greater

23 H. Pack and L.E. Westphal. op. cit.. page 87. 
pecuniary external economies, and thus cause a greater divergence between private profit and social benefit." 24

For Pack and Westfall the important duality is not so much between the production and the investment decisions as suggested by Scitovsky, however, it is between "investments in established industries where there is a static comparative advantage and investments in infant industries where there is potential for a dynamic...comparative advantage. "25 To a considerable extent it is this function of guided investment which initially distinguishes between the growth efforts of the Central American nations and the development efforts of Taiwan and South Korea.

Many others who have studied the development of the ENICs have arrived at comparable conclusions. Paul Kuznets observed that "This emphasis on 'growth' (by the government) means that dynamic rather than static considerations are paramount, and dynamic efficiency is a topic about which the traditional neoclassical market paradigm has surprisingly little to say. 26 Pack as well states that though he has some doubts about the efficiency of the government intervention by both Taiwan and South Korea since the mid-1970s, it is unlikely that the private sector could have accomplished the earlier efforts without the government involvement. Figure 3, below, represents the history of the policy development for the two nations.

Both nations combined import substitution in the early years with an export focus following the development of the internal economies. While Taiwan used an indicative planning approach with little institutional linkage of the government and the private

\footnotetext{
24 Tibor Scitovsky. "Two Concepts of External Economies", in A.N. Agarwala and S.P. Singh. eds., The Economics of Underdevelonment. New York, Oxford University Press, 1963, pages 305 and 306. This anicle was reprimted by Agarwala and Singh from the April. 1954 issue of The Joumal of Political Economy. University of Chicago.

25 H. Pack and L.E. Westphal, op. cil., page 125.

26 Paul W. Kuznets, op. cit.. page S37.
} 
economy, the Korean government intervened directly into the private economy through what became a substantial policy bureaucracy.

Both nations followed approximately the same broad pattern of policy.

The first, generally between 1950 and 1960, was the period of internal focus, the import substitution phase. During this early transition phase Both nations had a labor surplus, resource poor, and open, dualistic economies with a colonial heritage. As will be seen in the data presented in chapter 8, labor was employed mainly in agriculture, a substantial part of which was exported. The resulting foreign exchange, then, was used to import manufactured consumer goods. A substantial part of the income which was generated through agricultural production was paid to labor and land, and it constituted the purchasing power available in the domestic market for consumption.

The initial phase development effort was focused on developing the economy internally both in terms of capacity to manufacture a significant part of the imported goods and in terms of the purchasing power necessary to support that capacity. A priority was put on the latter goal, the development of national purchasing power, a goal which was not present in Central America during the post-World War II period. This is a critical distinction which aligns the efforts in Taiwna and South Korea with the research and conclusions by Kuznets, and separates the efforts made by the CANs from the same conclusions.

The second phase, from 1960 to roughly 1980 , was the period of external orientation, where the intent was to focus the economy on export markets. This phase was focused on generating industries which were capable of producing manufactured goods which were competitive in world markets. It was during this phase that labor intensive exports from the industrial sector were added to the agricultural exports. This was possible because during the earlier phase, the capacity, in terms of the industrial 
capital base, the expertise and the industrial labor was created. Li, Ranis and Fei refer to this phase in Taiwan as the export substitution phase "because the comparative advantage of the country has (been) shifted from exports based on (Taiwan's limited) natural resources to exports based on labor." 27

The most recent phase, since 1980, is referred to by Ranis and $\mathrm{Li}$ as the technology oriented phase in Taiwan. It is clearly a continuation of the external orientation phase in one sense, but it also represents the maturation of that phase. During the 1970s both the policymakers and the entrepreneurs promoted the constant increase in both the quality and the sophistication of products made in the country. The fact that Taiwan came to be identified with technological competence was entirely by intent on the part of policymakers. It is also in keeping with the basic tenet of Kuznets' conclusions, the emphasis on the development of knowledge and science as a critical element of modern economic growth.

The latter phase has been described as the technology sensitive one which marked the point where the economy was nearing the end of the "transition growth" (development) period. This is the phase at which the economy began to actually move into modern economic growth. It was during this phase that further development began to be "marked by routinized reliance on science and technology. "28 The latter phase of the process, the technology oriented phase, represents the conscious achievement of what is referred to in Kuznets' terms as the basic innovation in the modern growth epoch, the conscious, sustained and institutionalized application of science-fed technology to industrial production.

\footnotetext{
27 K. T. Li. The Evolution of Poliev Bethind Taiwan's Development Suceess. New Haven, Yale Universily Press, 1988, page 36 .

28 Gustav Ranis. "The Evolution of Policy in a Comparitive Perspective", in K. T. Li. The Evolution or Poliev Behind Taiwan's Develonment Success. New Haven, Yale University Press. 1988. page 10.
} 
POLICY EVOLUTION DURING THE DEVELOPMENT PERIOD

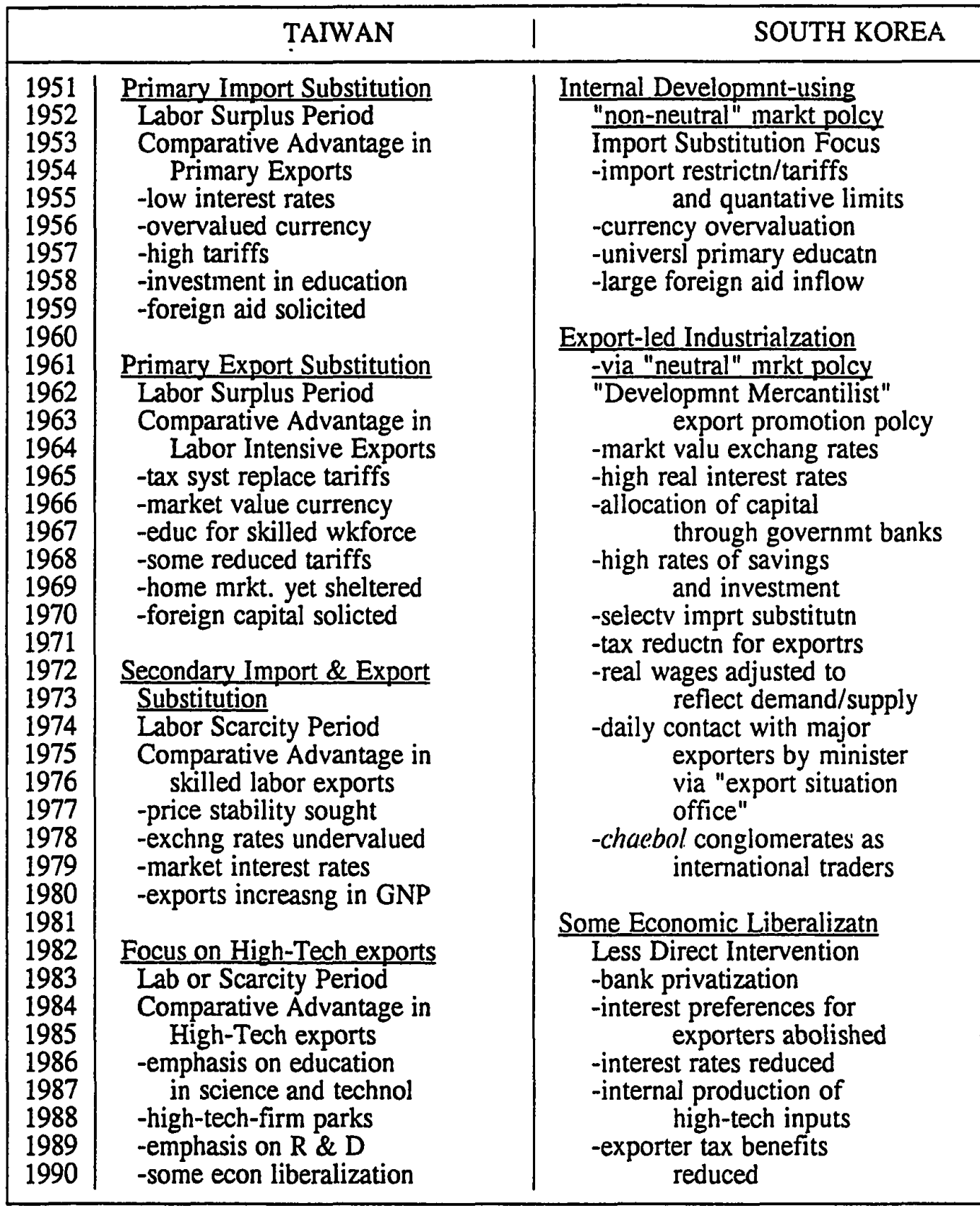

Figure 3. The History of Policy in Taiwan and South Korea. 
"THE EAST ASIAN MODEL..."29

For Paul Kuznets the "East Asian Model" for development, drawn from the experience of Japan, as well as Taiwan and South Korea, is summarized by a list of seven shared characteristics. They include the high investment ratios, relatively small public sectors and export expansion which are often discussed by U.S. and Central American neoclassicists as desirable. But they also include attributes which are typically not mentioned, particularly by the Central Americans. Those are competitive labor markets, large and efficient investments in human capital, responsible government intervention into the economy and a well developed capacity to absorb new technology. 30

All of the characteristics distinguished by Paul Kuznets in the 'East Asian Model' are characteristics as well of an economy in transition to modern economic growth as defined by Simon Kuznets. In his article on the 'East Asian Model' Paul Kuznets mentions two other shared characteristics of the East Asian economies. Those are a high population to land ratio and a paucity of natural resources. He points out that although those characteristics are more likely to be seen as handicaps, it is entirely possible that virtue springs from necessity in those cases. "Ample arable land and abundant natural resources", he says in the conclusion to the article, "mainly permit governments to postpone the difficult decisions needed to promote development (of the nation as a whole)."

Paradoxically, even that disadvantage was shared by the Central American nations. Virtue, in the Central American case, did not spring from the necessity of substantial population and inadequate natural resources. It is entirely possible to

\footnotetext{
29 Paul W. Kuznets, "The East Asian Model of Economic Developunent: Japan. Taiwan and South Kurea". Economic Develonment and Cultural Change, Vol. 36. Number 3. April 1988.

30 Paul W. Kuznets, op. cit., pages S34 and S35.
} 
postpone the difficult decisions needed to promote development even without ample land and natural resources. As will be seen in chapter nine, the ability to rely extensively upon external capital and debt also helps to postpone the difficult decisions. 


\section{CHAPTER VIII}

\section{THE STATISTICS OF ECONOMIC DEVELOPMENT AND ECONOMIC GROWTH}

\section{THE EASTERN NEWLY INDUSTRIALIZED COUNTRIES}

The problems of using national data for comparison are the classic ones, including differences in data collected, in collection methods, in frequency, in statistical manipulation before publication and so on. Thus the decision was made to use data published by the World Bank, the International Monetary Fund and the United Nations.

The indicators which follow in this chapter, are taken from several sources. Those for South Korea and the CANs were taken from published sources of the international agencies. They include the World Bank, the International Monetary Fund and the United Nations. That data, though it often involved substantial subsequent calculations and manipulation, is directly consistent with that of the CANs.

The indicators for the Taiwanese economy, on the other hand, are drawn from very different sources. For the most part they are taken from books of data published by the government of the Republic of China specifically for the purpose of evaluation of the performance of the economy. The majority of it came from a sizable manual of data published by the ROC Council for Economic Planning and Development (CEPD). ${ }^{1}$ Also used was the Industry of Free China, CEPD, Monthly Statistics of the

\footnotetext{
1 Council for Economic Planning and Development. Taiwan Sintistical Dala Book - 1990. Republic of China, 1991. This was obtained through the Chief Economist. Economic Division. Conrdination Council for North American Affairs for the Republic of China in Washington DC.
} 
Republic of China, Directorate General of Budget, Accounting and Statistics and others which will be noted below.

An important element of a guided development process is the generation, gathering and publication of the detailed structural data which is necessary to development policy. Such data for Taiwan was found to be available in highly disaggregated form, even in the English translations of the data.

Table 1-1a (page 1) in the Taiwan Statistical Data Book presents basic "Indicators of the Taiwan Economy", inciuding data on the three key sectors. Subsequent Tables in the Section give further breakdowns of all that presented in 1-1a. But the detail goes much further. Section 4 in the same manual, for example, deals with the thorough breakdown of data related to agriculture. Section 5 deals similarly with Industry, Section 7 with Transportation and Communications, and so on through the book.

As an example it is worth listing the sub-headings in one of those sections, each of which represent several more pages of breakdown within that sub-heading. Under Agriculture the sub-headings include the following:

1. Area of Cultivated Land.

2. Multiple-Cropping Index.

3. Agricultural Population by Owners and Tenants.

4. Cultivated Land, Agricultural Cultivation and

5. Agricultural Production.

6. Area and Output of Principal Crops.

7. Allocations of Chemical Fertilizer.

8. Chemical Fertilizer Allocated for Rice Cultivation.

9. Chemical Fertilizer Used for Sugarcane Cultivation.

10. Forest Areas and Reserves.

11. Forestry Production.

12. Fisheries Production.

13. Livestock Production.

This particular book of data contains seventeen major headings, including "Science and Technology", "Income", "Education", "Health and Medical Care" and so on. Each of 
those headings represent sub-headings such as those above for Agriculture, and each sub-heading contains a few pages of further breakdown.

It is not happenstance that the headings in this manual coincide well with the description of the structural changes necessary for the Kuznetsian concept of modern economic growth. Most of the literature of the last decade or so which discusses the policy decisions since World War II in Taiwan makes mention of the importance of the Kuznets model.

As was discussed in the literature review, Kuznets made a strong point of the need to incorporate science into the development process. Science comes up often in the discussions and plans of development in Taiwan, and in the Taiwan Statistical Data $\underline{\text { Book, }}$ the Science and Technology heading breaks down research and development expenditures by sector, by industry, by type, by field of research, by education of researchers and on. ${ }^{2}$ Such data, of course, is necessary to the management of the economy as described in the last chapter regarding the ENICs.

The classic growth indicators, Gross Domestic Product and Gross Domestic Product per Capita are used in this study because, though they will not distinguish between economic growth and economic development, they provide a base line which indicates whether or not the economy as a whole is expanding or contracting. A contracting economy, of course, is neither growing nor developing. Determining whether or not an expanding economy is developing requires further indicators which portray structural elements of the economy and structural change related to those elements.

\footnotetext{
2 See, for example. K.T. Li, Gustav Ranis and John C.H. Fei. The Evolution of Palicy Behind Taiwan's Develonnent Success. New Haven. Yale University Press. 1988. The book is full of references to Kuznets and his concept of modem economic growth, but John C.H. Fei makes particular point of discussing policy in the development process in the introductory chapter entited "A Birds eye view of Policy Evolution on Taiwan". p. 26-46.
} 
Figure 4 portrays the GDP figures for Taiwan. It represents a classical growth process over the 30 years. The data is adjusted to 1981 prices and both GDP and GDP per Capita are indexed at $1960=100$ to facilitate comparison among the seven nations and to clearly illustrate the pattern of growth over the thirty year period.

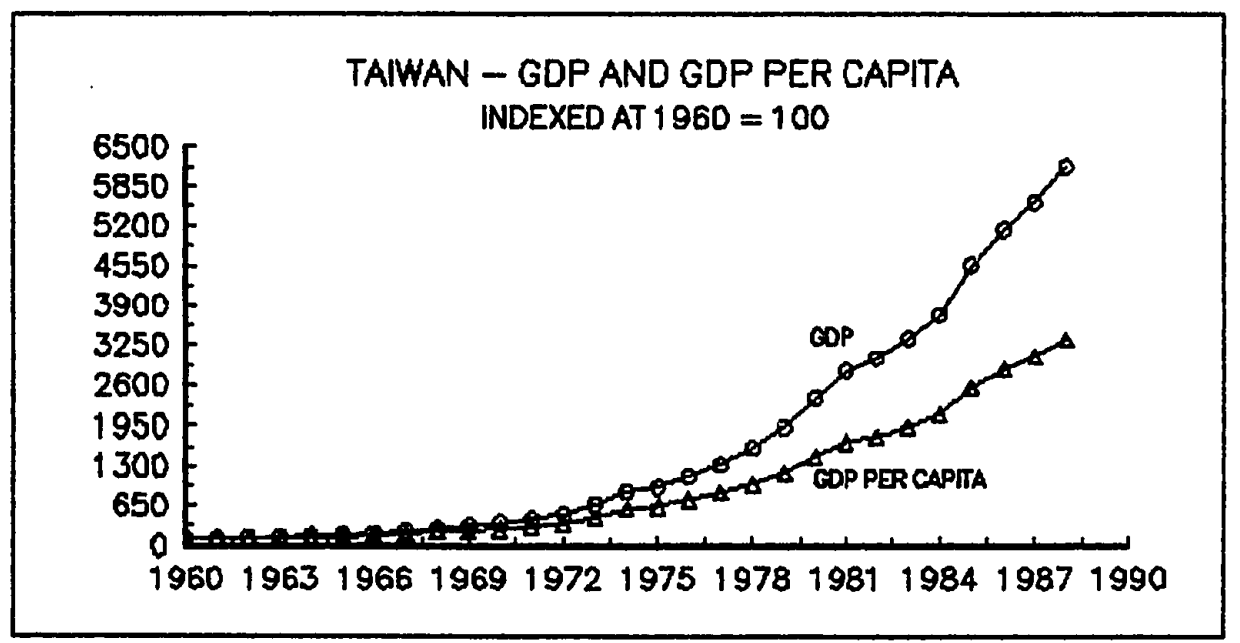

Figure 4. GDP and GDP per Capita for Taiwan. Source: Council for Economic Planning and Development. Taiwan Statistical Data Book 1990, Republic of China, 1991. Calculated from Table 3-2a and Table 22.

The same data for South Korea is shown in Figure 5. The pattern appears to be quite similar to that for Taiwan except for the one year drop in GDP which shows up in 1980. That drop will be taken note of later when the larger pattern of indicators is considered. Here again, the data is adjusted to 1980 prices and indexed at $1960=100$ as above for Taiwan.

The first set of indicators which are development-type indicators are thosewhich portray the initial breakdown of GDP into the three key sectors. Representation of GDP as composed of agriculture, services and industry represents a fundamental structural breakdown of the economy. 
That important part of the record of structural change is illustrated here in

Figure 6, for the years 1960 to 1989 . The picture presented of the changes in the three

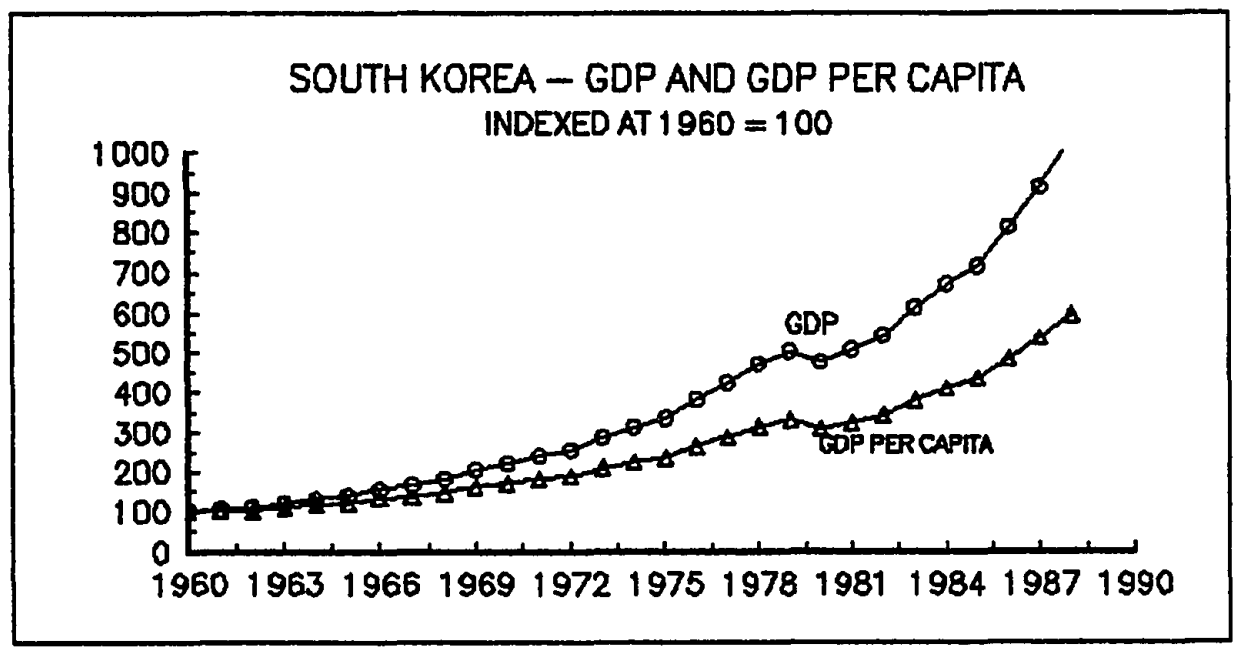

Figure 5. GDP and GDP per Capita for South Korea. Source: The World Bank. World Tables - 1990, Baltimore, The Johns Hopkins

University Press, 1990. Calculated from the Country Pages, pp. 340343.

major sectors is an illustration of Kuznets' expectations. ${ }^{3}$ A structural transformation which is critical to modern economic growth is, as described by Kuznets, "...the shift away from agriculture to nonagricultural (industry and services) pursuits." 4

The graph clearly illustrates a dramatic decrease in the percentage of agriculture in GDP. Agriculture declined from 32 percent of GDP in 1960 to 6 percent in 1988. A dramatic drop indicating a clear change in economic structure. At the same time industry increased from 24 percent of GDP in 1960 (it was 16 percent in the early

${ }^{3}$ In the lecture delivered in 1971 upon receipt of the Nobel Prize in Economics Kuznets describes a high rate of structural transformation of the economy as the third (of six) characteristics of modem economic growth. Specifically, he describes a shif away from agriculture and toward industry and services as necessary. Sec. Simon Kuznets. "Modern Econonic Growth: Findings and Reflections", American Economic Review, V.63, June 1973, pages 247-258. For this specific reference see page 248.

\footnotetext{
${ }^{4}$ Kuznets, op. cit.. page 248.
} 


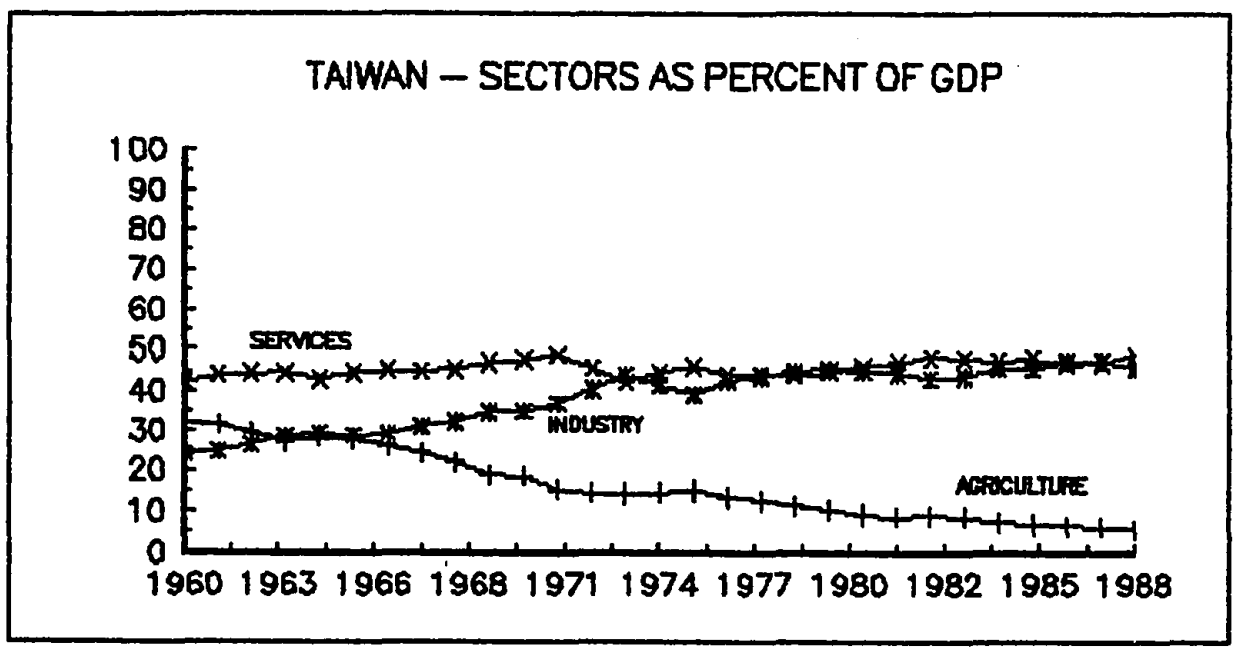

Figure 6. Taiwan - The Sectors as a Percentage of GDP. Source:

Calculated from Council for Economic Planning and Development.

Taiwan Statistical Data Book - 1990, Republic of China, 1991. Table 3-

$7 \mathrm{a}$ - Domestic Product by Kind of Activity.

1950s) to 46 percent in 1988. Again, indicating a corresponding part of the major structural transformation seen in the decrease in agriculture. That services also picked up some of the decrease in agriculture can be seen in this graph, though showing a less dramatic change. Services, here, increase from 42 to 48 percent of GDP.

South Korea shows a very similar pattern. Figure 7 shows the changes in Korea to illustrate the Kuznetsian expectations with respect to structural change among the three sectors with some minor distinctions from that of Taiwan.

Here, agriculture declines from 34 percent of GDP to 10 percent in 1988, while industry rises from 22 to 50 percent of GDP. Thus far South Korea's is a pattern very like that of Taiwan. The minor difference can be seen first in the fact that services actually decline slightly over the entire period. In the long run it appears that more of the decrease in agriculture was picked up by industry in South Korea than in Taiwan. Whereas in Taiwan the change in percentage of GDP represented by industry appears to level off about halfway through the period, in South Korea it continues to climb, 


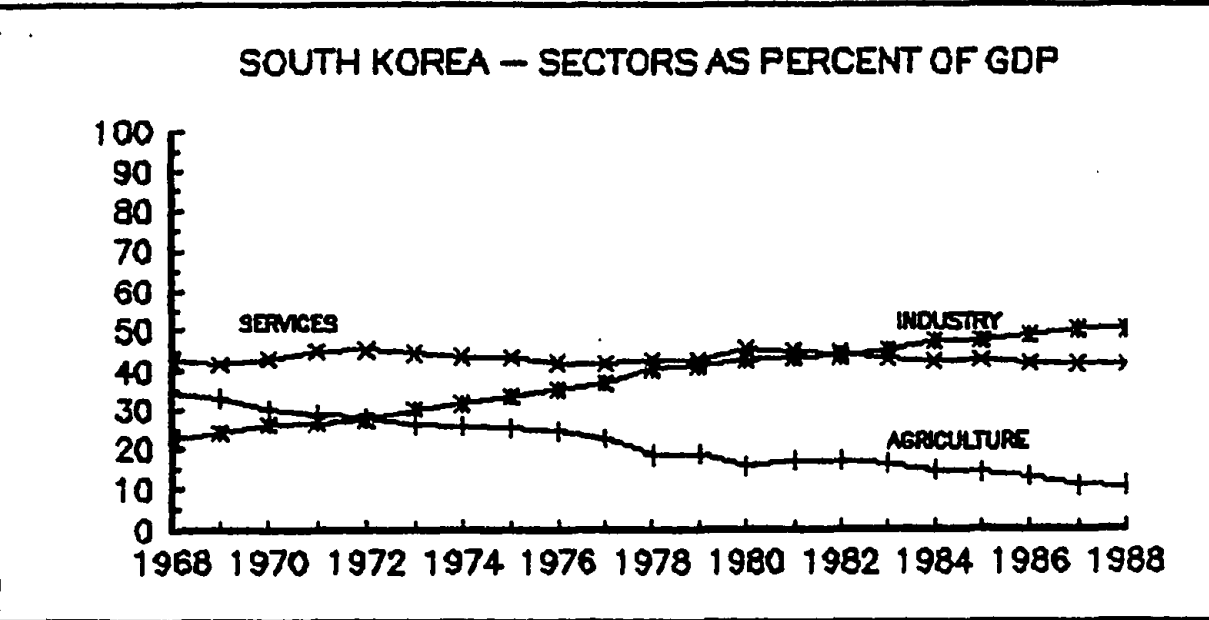

Figure 7. South Korea - The Sectors as a Percentage of GDP. Source: The World Bank. World Tables - 1990, Baltimore, The Johns Hopkins University Press, 1990. Calculated from the Country Pages, pp. 340341.

surpassing the percentage represented by industry in Taiwan.

The next development indicator to be examined here is Private Consumption per Capita. As will be seen in the graphs of Private Consumption for the CANs in the next section of this chapter, it is entirely possible to have 'growth', even over an extended period in a national economy, without an improvement in per capita consumption. On the other hand, among the changes which are considered necessary by Kuznets as an indicator of modern economic growth, are those related to output and subsequent consumption by the population as a whole.

In the discussion of the anticipated structural changes, in his extensive treatment of modern economic growth in 1966, Kuznets states that though high rates of population growth are to be expected, even higher rates of per capita product and 
consumption can be expected to occur. ${ }^{5}$ The data for Taiwan and South Korea in Figure 8 illustrates this phenomenon well.

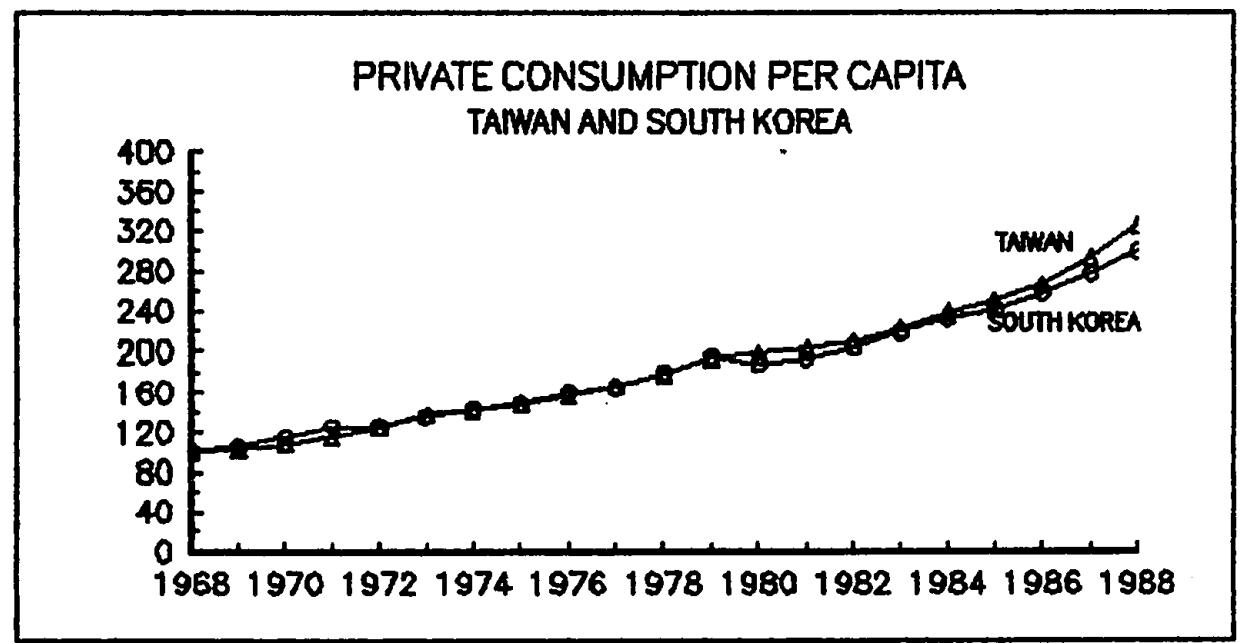

Figure 8. Private Consumption per capita. $1968=100$. Source: The World Bank. World Tables - 1990, Baltimore, The Johns Hopkins University Press, 1990. Table 3, pages 10 \& 11 and calculated from Council for Economic Planning and Development. Taiwan Statistical Data Book - 1990, Republic of China, 1991. Table 3-8a, Expenditure on GDP.

It is apparent that even with the relatively rapid population growth which characterized both nations, private consumption increased substantially during the two decades represented. Thus, while increase in consumption accompanied the increase in GDP for the ENICs, it will be seen in the next section of this chapter that for the CANs 'growth' did not mean an increase in per capita consumption.

A related consumption indicator is Private Consumption as a Percentage of GDP. The Kuznetsian expectation for this indicator in a development context is that it will decrease over the transition period. Figure 9 presents that indicator for South Korea and Taiwan.

5 Simon Kuznets. Modern Economic Growlh: Rate, Siructure and Snread. New Haven. Yale University Press, 1966. The discussion of 'Implications of Population Growth' hegins on page 56, but even more to the point here is the discussion of 'Per Capita Growh of Product' on pages 63 to 72. 


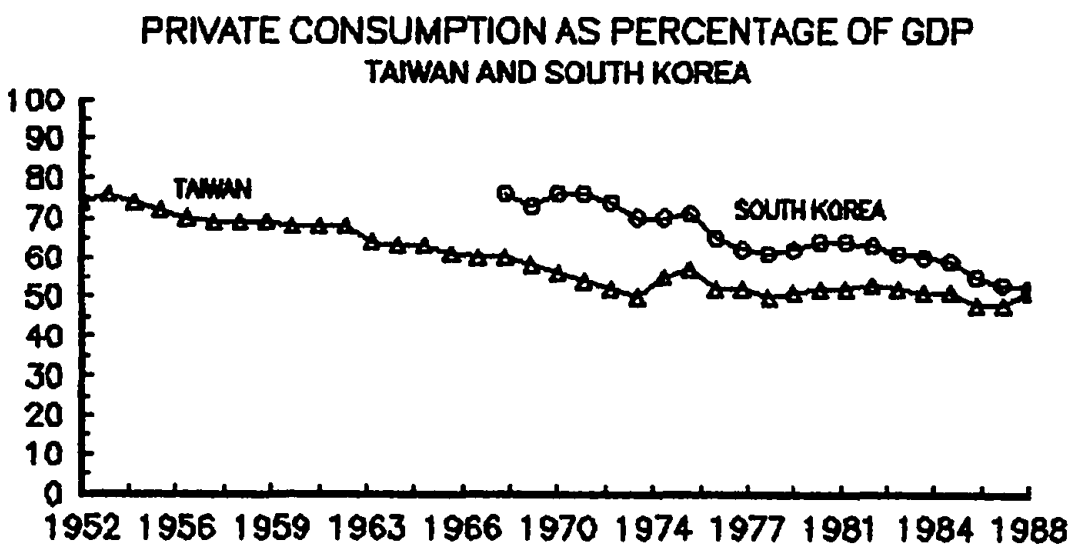

Figure 9. Private Consumption as percentage of GDP. Source: The World Bank. World Tables - 1990, Baltimore, The Johns Hopkins University Press, 1990. Table 15, pages 58 - 61 and calculated from Council for Economic Planning and Development. Taiwan Statistical Data Book - 1990, Republic of China, 1991. Table 3-8b, Expenditure on GDP.

The increase in total output in a developing nation is expected to provide an increase in per capita consumption while at the same time showing a decrease in consumption as a part of GDP. Figure 9 shows just that pattern for both South Korea and Taiwan.

The next development-type indicator which will be examined here is Gross Domestic Savings. This indicator, also clearly distinguishes the ENICs from the CANs, and distinguishes the nations which are promoting and investing in structural change from those which are not.

Figure 10 illustrates the pattern in Domestic Savings as a percentage of GDP for the two ENICs. For Taiwan the data is available since 1952 while for South Korea the data in the World Bank format starts in 1968. The patterns are comparable and consistent, however. The additional time in the case of Taiwan simply extends the pattern to the opening years of the development process. Least squares lines have been 
pattern to the opening years of the development process. Least squares lines have been superimposed on the data for each nation to clarify the trend in the data in each case. These lines simply pass through the center of gravity of the data. 6

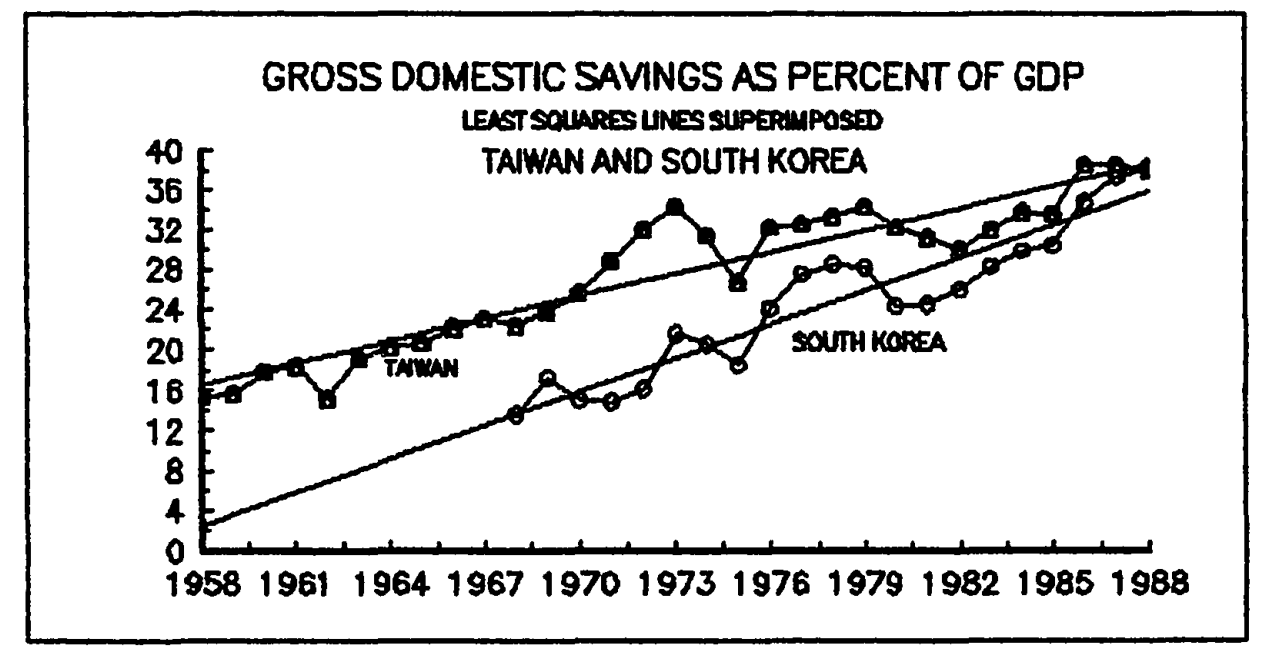

Figure 10. Savings as Percentage of GDP. Source: The World Bank. World Tables - 1990, Baltimore, The Johns Hopkins University Press, 1990. Table 14, pages 54 \& 55 and Council for Economic Planning and Development. Taiwan Statistical Data Book - 1990, Republic of China, 1991. Table 3-11, Savings as Percentage of GDP.

The process of structural change from the dominantly agricultural character of an underdeveloped economy to the primarily industrial economy which characterizes modern economic growth requires substantial capital formation. Recognizing that consistent data on capital formation is not available for the CANs, the decision was made to use Gross Domestic Savings because it measures the tendency of the economy to refrain from consumption for the purpose of investment. It is clear that foreign aid and foreign investment may create a dissociation of domestic savings from capital formation as such. But the intent here is not to represent capital formation through domestic savings, but to represent the capacity in the economy to invest a percentage of total output in keeping with the findings of Kuznets.

\footnotetext{
${ }^{6}$ An equation for the calculation of such a trend line can be found in any hasic statistics text.
} 
As is to be seen in Figure 10, domestic savings for Taiwan increased over the development period from 15 percent of GDP in 1958 to 38 percent in 1988. The increase in savings for South Korea was even more dramatic. From 13 percent of GDP in 1968 , it climbed to the same 38 percent in only twenty years. As GDP per capita increased in the ENICs the capacity to curtail current consumption also increased. The data will reveal that on the other hand, with the exception of Costa Rica, the CANs ended the twenty year period with a rate of savings which failed to increase during the 'growth' period, and which decreased on the whole.

Another important part of the pattern is Gross Domestic Investment (GDI). In this case it has been possible to generate two forms of the indicator in order to give two distinct perspectives on the economies. Figure 11 shows GDI per Capita. It illustrates two economies with growing populations which also have an annual rate of investment which is growing substantially faster than the population. These are economies with "an acceleration phase in the growth of capital stock. "7

Another slice of the same data, GDI as a percentage of GDP, shown in Figure 12 , also supports the notion of a nation engaged in modern economic growth. Kuznets found that, historically, the developing nations which innovated modern economic growth sustained rates of GDI at over 20 percent of GDP. The underdeveloped nations, those which were not engaged in the structural change necessary to development, consistently showed a rate less than 20 percent. 8 The mean rates during the twenty years portrayed for GDI as a percentage of GDP in these two nations is 28 percent for South Korea and 26 percent for Taiwan.

\footnotetext{
7 Simon Kuznets. "Toward a Theory of Economic Growth", in Robern Lekachman. Editor, National Policy for Economic Welfare at Home and Abroad. New York. Russell and Russell. Inc.. 1961. page 37.

8 Simon Kuznets. "Toward a Theory of Economic Growth", in Robert Letachman, Editor. National Policy for Economic Welfare at Home and Ahrnad. New York. Russell and Russell. Inc.. 1961, pages 36-40.
} 


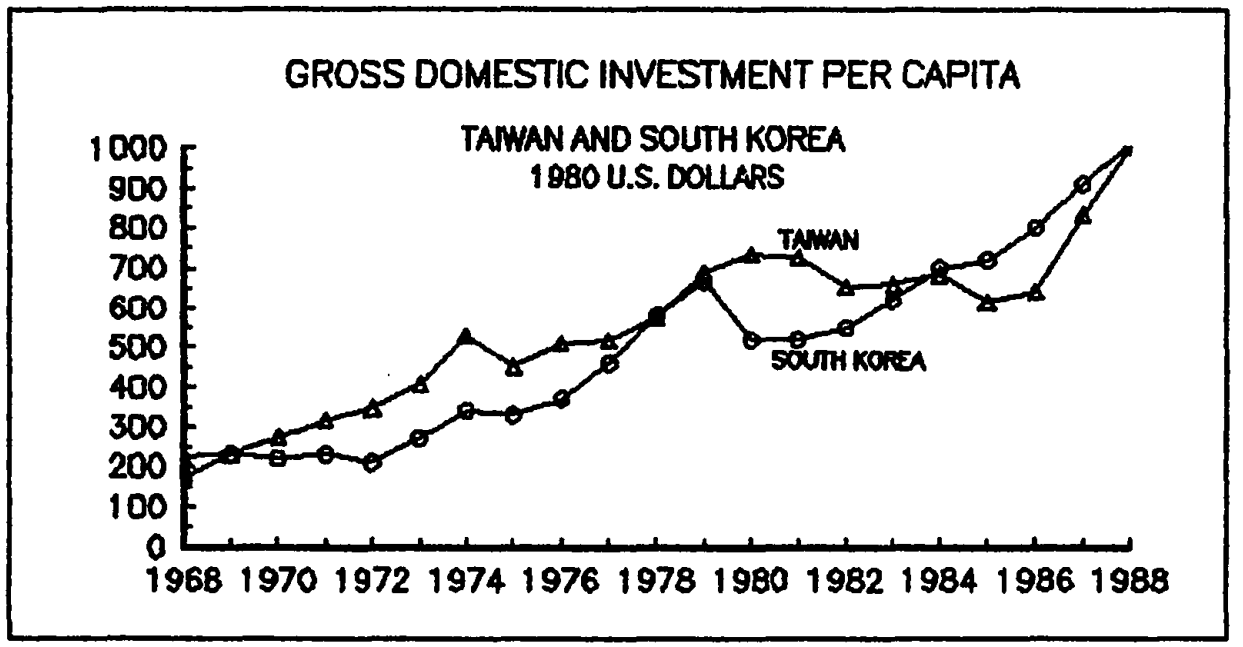

Figure 11. Gross Domestic Investment per Capita. Source: The World Bank. World Tables - 1990, Baltimore, The Johns Hopkins University Press, 1990. Table 4, pages $16 \& 17$ and Council for Economic Planning and Development. Taiwan Statistical Data Book - 1990, Republic of China, 1991. Calculated from Table 3-8b, Expenditure on GDP.

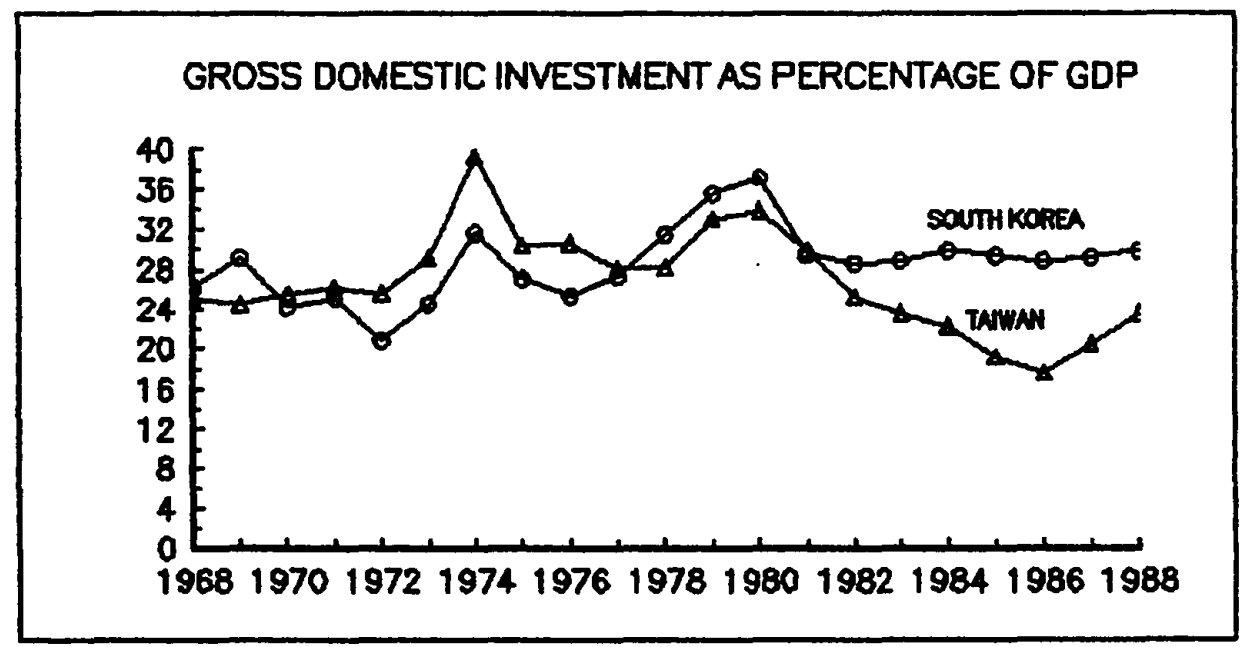

Figure 12. Gross Domestic Investment as Percentage of GDP. Source: The World Bank. World Tables - 1990, Baltimore, The Johns Hopkins University Press, 1990. Table 13, pages 50 \& 51 and Council for Economic Planning and Development. Taiwan Statistical Data Book 1990, Republic of China, 1991. Calculated from Table 3-8b, Expenditure on GDP. 
The last of the indicators, the rates of literacy for the seven nations under consideration, again shows a dramatic distinction between the CANs and the ENICs. Though the UNESCO generated data is limited for South Korea, the conclusions to be drawn are clear. Figure 14 shows a dramatic decline in illiteracy in all catagories to a point where South Korea is in the developed nation catagory with respect to the literacy of the population.

Taiwan shows a very comparable pattern in Figure 13. For Taiwan a detailed breakdown of the data is available in English. Demonstrating the fact that the data has been recognized to be necessary for the development effort, it has been collected and published in elaborate detail since 1952.

Section 14 of the Taiwan Statistical Data Book for 1990 contains page after page of data on, for example, the percentage of graduates enrolled in the next higher

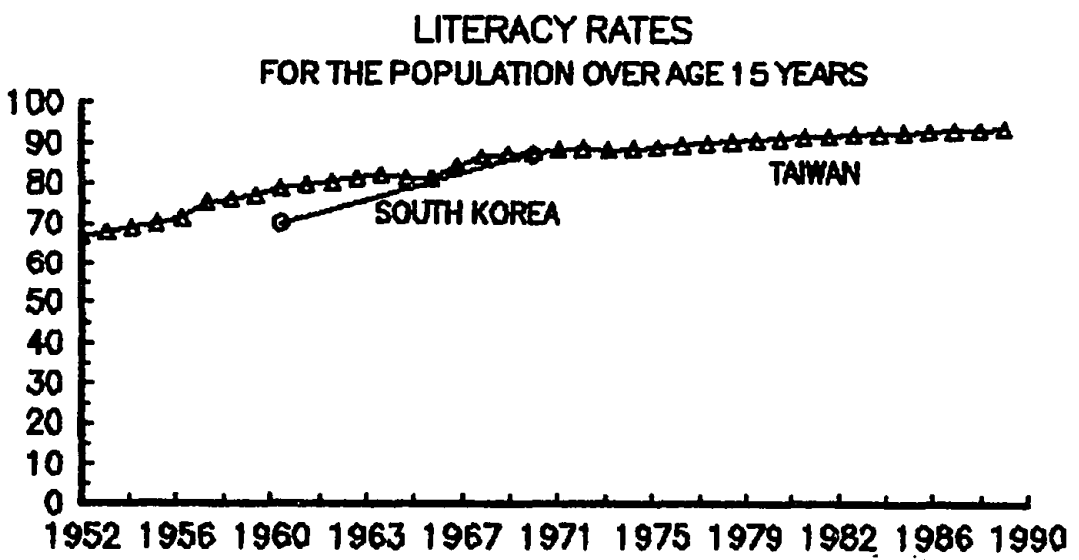

Figure 13. Taiwan and South Korea: Rates of Literacy. Source: Compendium of Statistics on Illiteracy - 1990 Edition, Division of Statistics on Education, Office of Statistics, Paris, UNESCO, 1990; Part Two, Illiteracy by Country. And Council for Economic Planning and Development. Taiwan Statistical Data Book - 1990, Republic of China, 1991. Calculated from Table 2-4a, Population by levels of Education. 


\section{ILLITERACY - SOUTH KOREA}

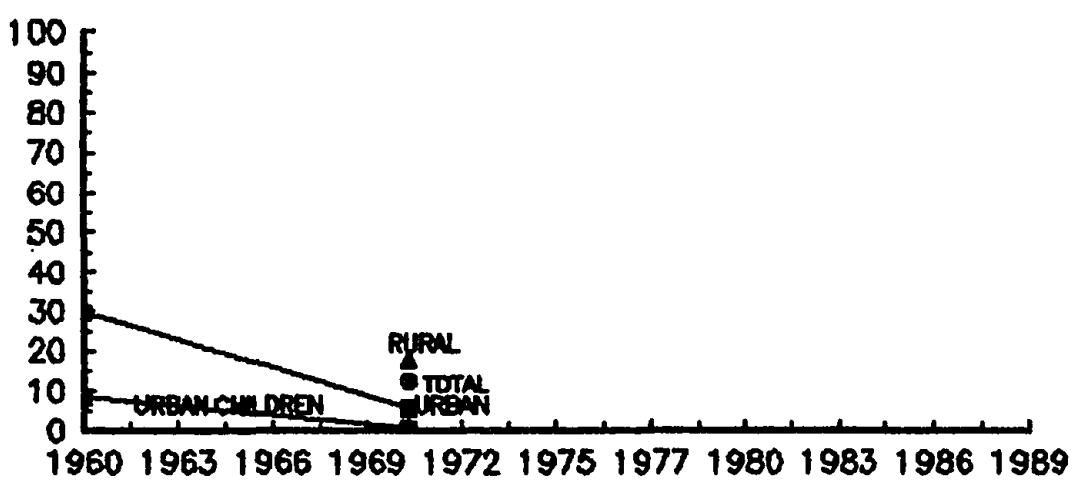

Figure 14. South Korea: Rates of Illiteracy. Source: Compendium of Statistics on Illiteracy - 1990 Edition, Division of Statistics on Education, Office of Statistics, Paris, UNESCO, 1990; Part Two, Illiteracy by Country.

level of schools, the number of students receiving secondary, academic and vocational education, the number of students receiving higher education by discipline, and so on. 9 Table 14-8 in the Taiwan Statistical Data Book the "Percentage of Graduates Enrolled in the Next Higher Level of Schools", shows a steady climb in all categories over the four decades. Particularly striking is the first two, the Percent of School-age Children enrolled in Primary Schools and the Percent of Primary School Graduates enrolled in Junior High Schools. By 1990 the percentages are $99.9 \%$ for enrollment in primary school and $99.6 \%$ of primary school graduates who continue to the next level. Considering that those numbers include the rural population, they portray a major emphasis on schooling for the population as a whole.

9 Council for Econonic Planning and Development. Taiwan Stalistlical Data Bonk - 1990, op. cit., see section 14, "Education", pages 277-292. 


\section{THE CENTRAL AMERICAN NATIONS}

For the five Central American countries, the data which was readily available and consistent over a substantial period of time consists almost entirely of 'growth', that is to say, aggregate, type data. Gross National Product and Income data are readily available, as is derivative data such as GNP per Capita. Even those figures become difficult to use, however, beyond a couple of decades back, due to changes in the form in which it is presented.

Even so, some highly aggregate development-type data is available for a long enough period to test the patterns against the Kuznetsian expectations. That includes data collected by the World Bank which separates GDP into the three sectors, agriculture, industry and services. These data are sufficient for the purposes here to suggest in retrospect whether development took place or not. They would be thoroughly inadequate to guide ongoing policy, however.

Some of the more important development indicators such as School enrollment, food production and distribution of employment information is gathered by the United Nations and the World Bank. But a glance at the Country Pages of the World Bank's World Tables for the last few years illustrates that although it is useful in theory, in reality it is only sporadically available. The development-type data which is available, though, readily supports the patterns of the growth-type data which is more readily and consistently available.

For El Salvador and Guatemala, for example, the fairly sporadic data which is available in the World Tables shows a clear decline in the 1980s in employment, real earnings for those who were employed, real output per employee and earnings relative to value added. The graph below, Figure 15, for El Salvador presents the data which is available. 
The comparable data for Guatemala is much more sporadic, and that for Costa Rica and Honduras is simply not available at all. For Nicaragua, on the other hand,

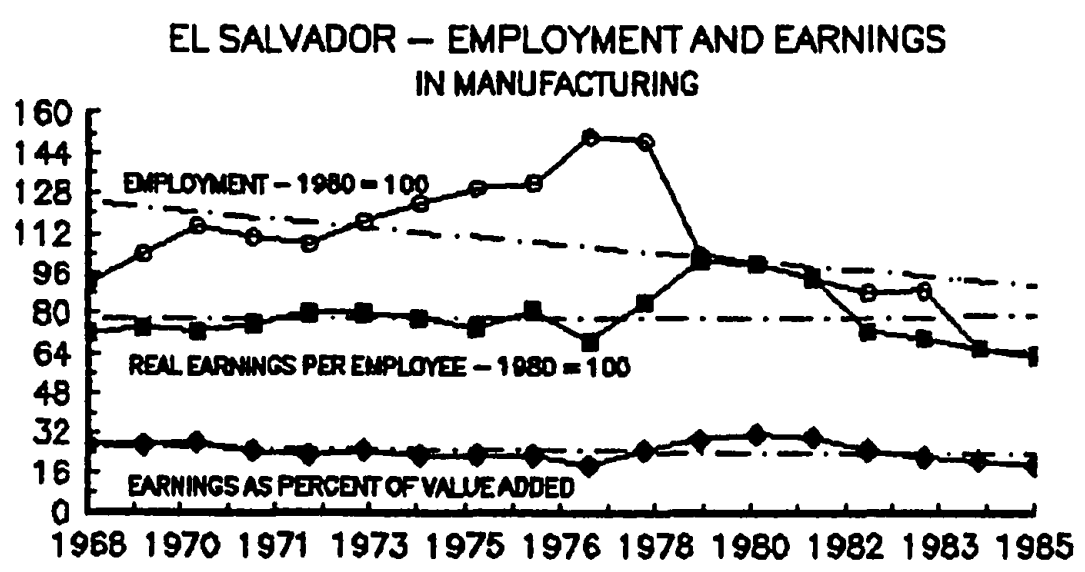

Figure 15. El Salvador: Employment and Earnings. Source: World Tables - 1990, The World Bank, Baltimore, The Johns Hopkins University Press, 1990. Calculated from the "Country Pages" 228-229.

though the data is sporadic, it shows a unique and interesting pattern which was without a doubt a function of the siege-like environment in which policy was being made by the Sandinistas. Specifically, Nicaragua is the only nation among the five where employment and output per employee increased during the 1980s. earnings, on the other hand, decreased dramatically as it did in the other Central American Nations.

The graphs above for El Salvador represent an economy with serious problems, whether considered from the point of view of growth or development. In the last third of the 1970s employment began to drop precipitously and has continued to do so since. Earnings, in terms of value added, stayed near or below the 1968 level while real earnings, except for a brief jump which coincides with a dramatic drop in employment, dropped well below the 1968 level.

While the data represented above is adequate to suggest some insight into the development problems, it falls well short of the disaggregated form of the same data 
which would be necessary to make policy decisions in response to the problems represented there. Management of the economy for intentional development would require considerable distinction within each of those catagories in order to focus support or discouragement of specific economic activity.

For all five Central American Nations the classic growth-type indicator, Gross Domestic Product and Gross Domestic Product per Capita tell a consistent story. Figures 16 through 20 show that data for the five nations. All five are based on figures adjusted to 1980 prices in the domestic currency. All five also were indexed at 1960 equal to 100 for the sake of consistency and to emphasize the thirty year record.

In the 1960s, with the emergence of the Central American Common Market, the growth of GDP in the five nations was often cited as illustration of the success of the effort. Of concern in the late 1970s and throughout the 1980s, however, was that all five economies experienced a devastating collapse of growth. That is clear in the GDP

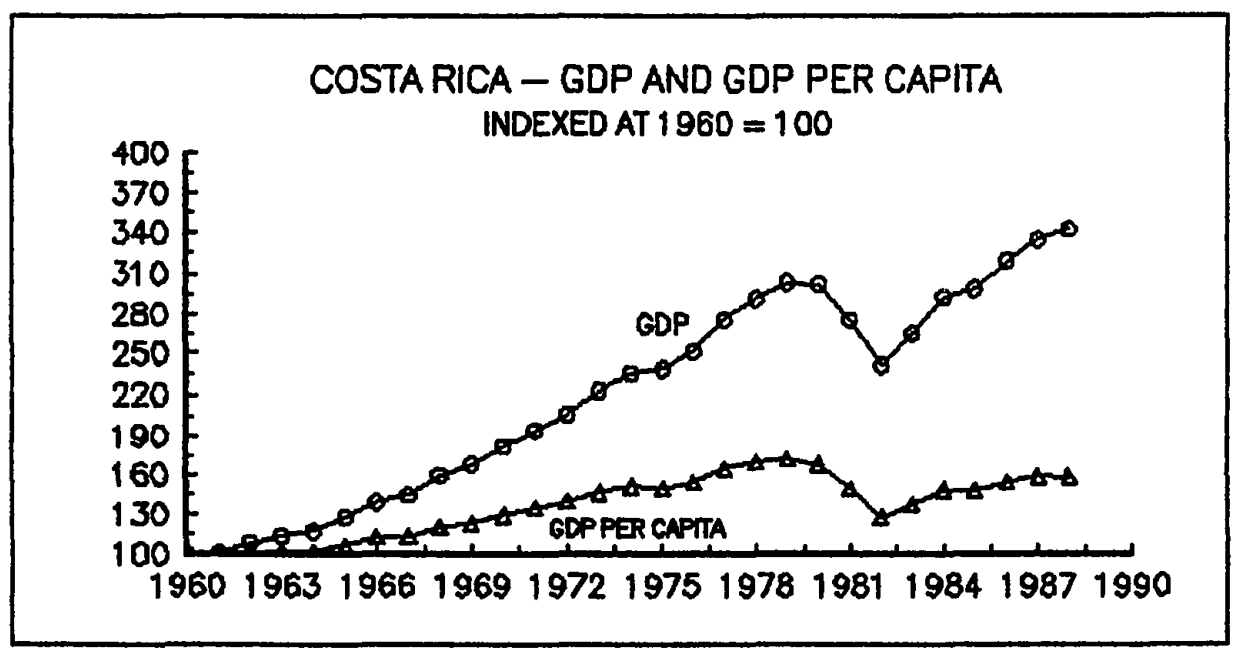

Figure 16. Costa Rica: GDP and GDP per Capita. Source: Calculated from International Financial Statistics Yearbook, International Monetary Fund, Washington D.C., 1980, and World Tables - 1990, The World Bank, 1990. Country Pages. 


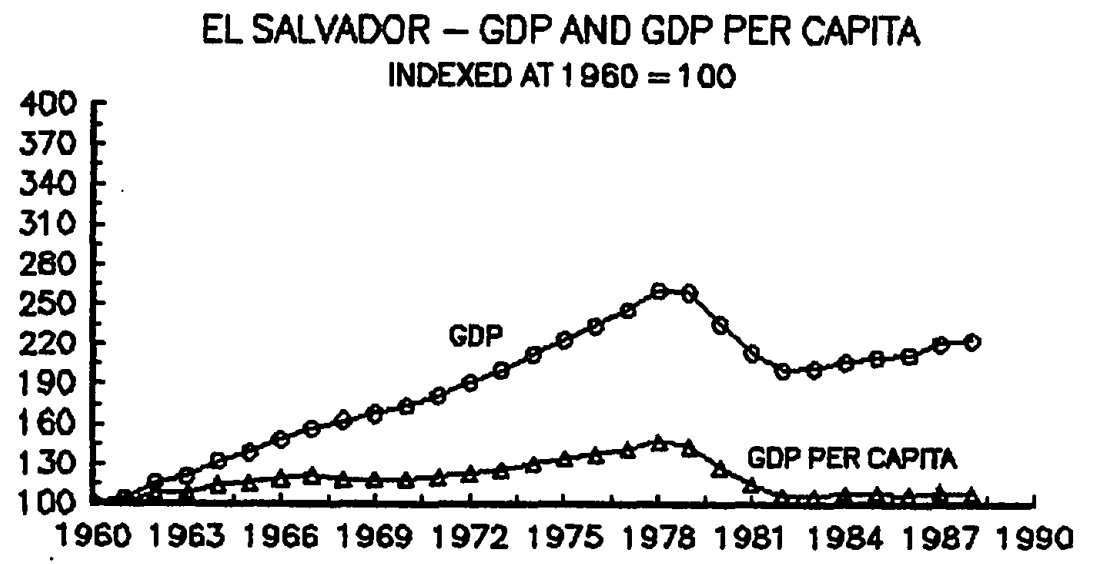

Figure 17. El Salvador: GDP and GDP per Capita. Source: Calculated from International Financial Statistics Yearbook, International Monetary Fund, Washington D.C., 1980, and World Tables - 1990, The World Bank, 1990. Country Pages.

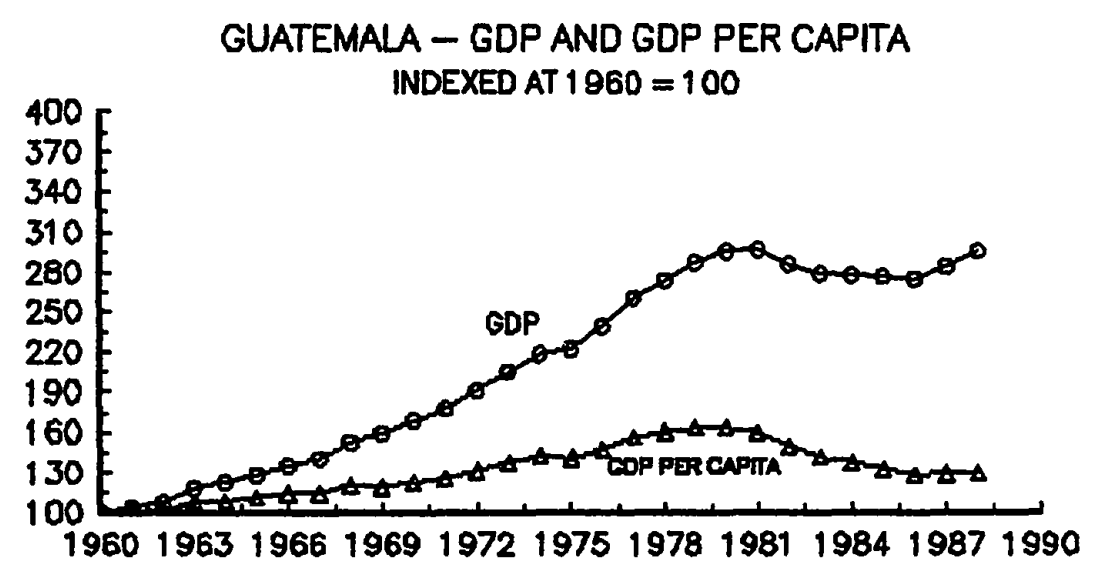

Figure 18. Guatemala: GDP and GDP per Capita. Source: Calculated from International Financial Statistics Yearbook, International Monetary Fund, Washington D.C., 1980, and World Tables - 1990, The World Bank, 1990. Country Pages. 


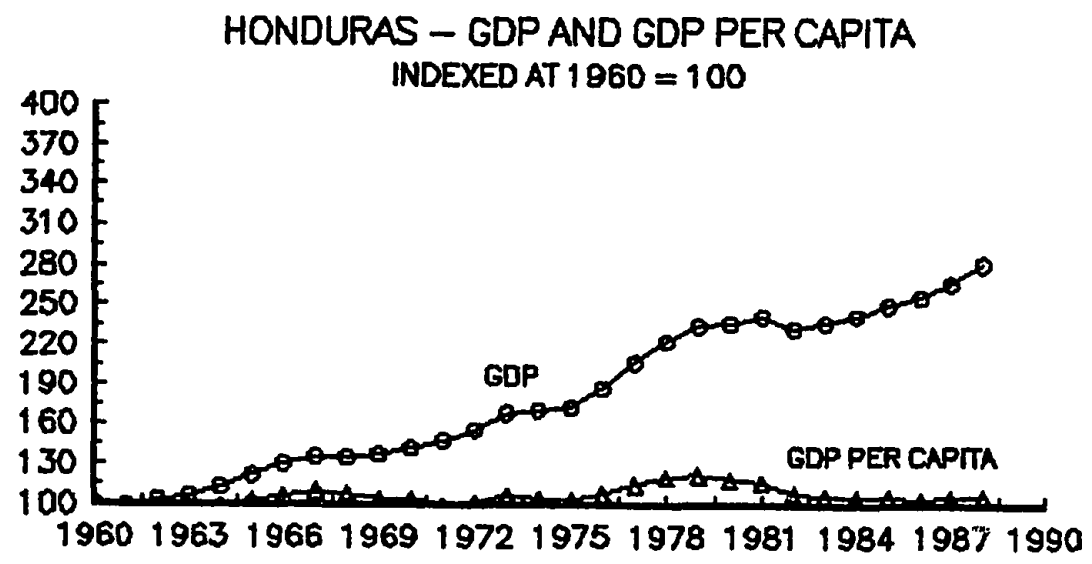

Figure 19. Honduras: GDP and GDP per Capita. Source: Calculated from International Financial Statistics Yearbook, International Monetary Fund, Washington D.C., 1980, and World Tables - 1990, The World Bank, 1990. Country Pages.

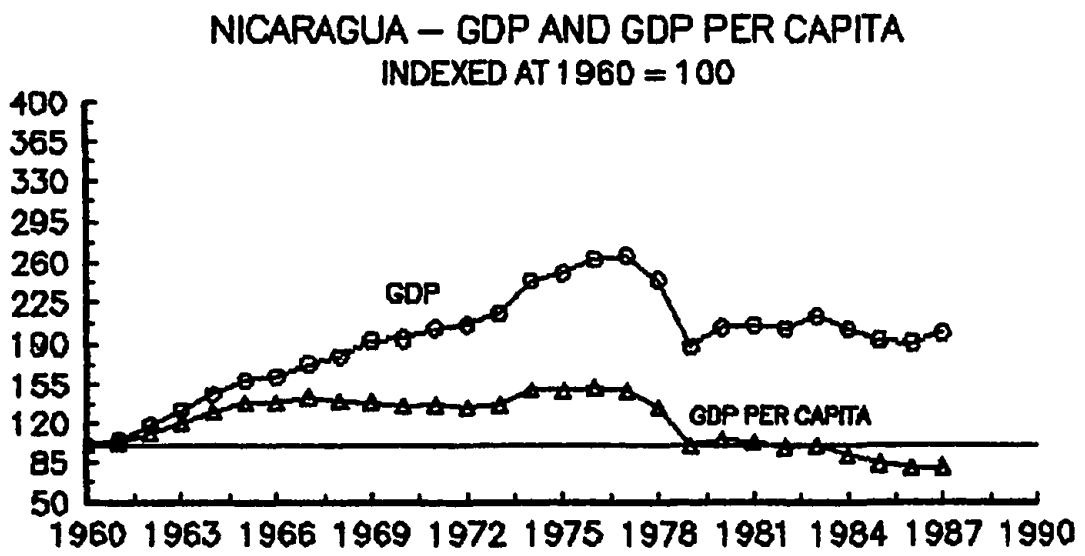

Figure 20. Nicaragua: GDP and GDP per Capita. Source: Calculated from International Financial Statistics Yearbook, International Monetary Fund, Washington D.C., 1980, and World Tables - 1990, The World Bank, 1990. Country Pages. 
figures and it will be seen to be apparent in all of the other growth-dependent data as well.

Even exclusively growth-focused policymakers must have seen a warning in the nearly flat GDP per Capita pattern for all five nations. From a development position, on the other hand, it is especially apparent that improvement in the welfare of the population as a whole is at least in question. Without income distribution data, however, and there is none available for those nations, addressing questions about the incorporation of the population as a whole into the 'growth' process depends primarily upon anecdotal information. Of such anecdotal information there is a plethora in Central America, all giving evidence in retrospect that development did not take place. But such evidence is far from helpful for policy decisions.

More suggestive of development-type concerns, and specifically consistent with Simon Kuznets' proposed indicators of modern economic growth, is data on the three key sectors, industry, agriculture and services, which comprise GDP. Figures 21

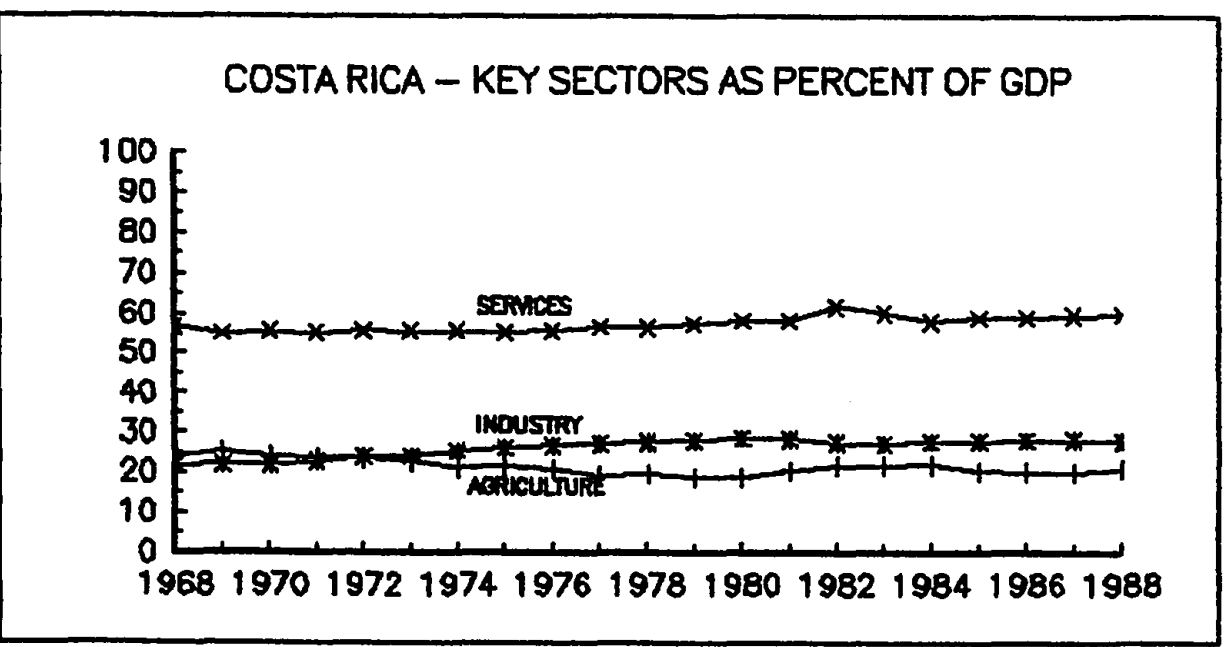

Figure 21. Costa Rica: Economic Sectors as Percent of GDP. Source: World Tables - 1990, The World Bank, Baltimore, The Johns Hopkins University Press, 1990. Calculated from the "Country Pages" 196-197. 


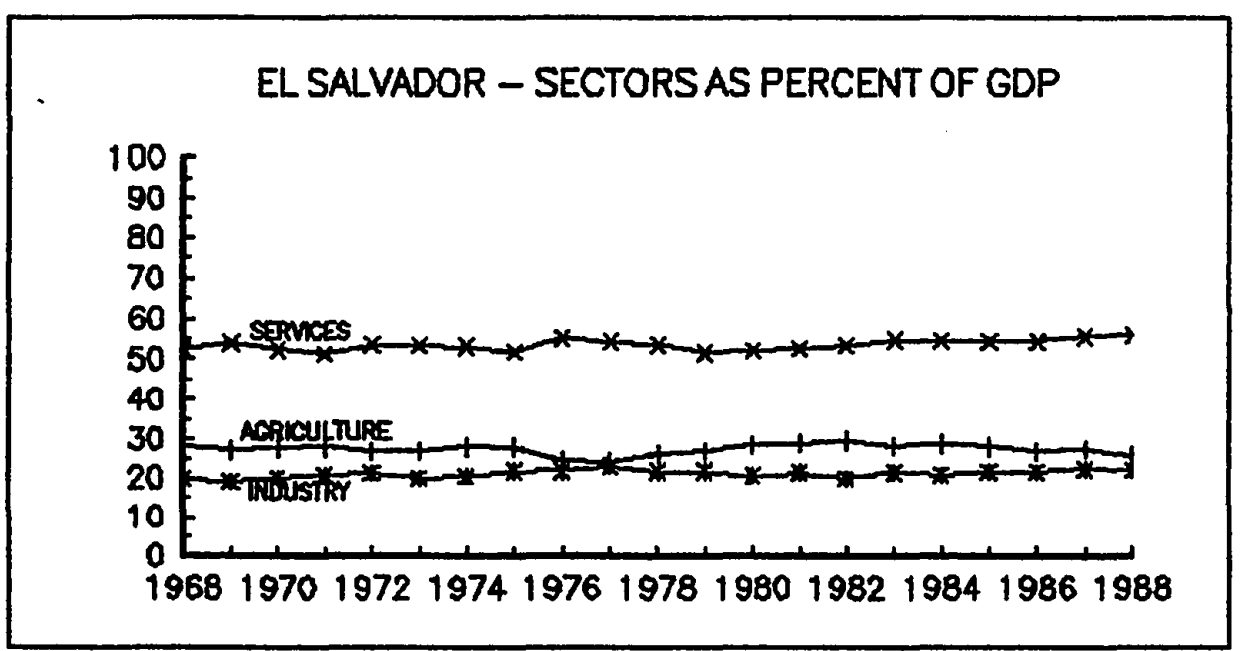

Figure 22. El Salvador: Economic Sectors as Percent of GDP. Source: World Tables - 1990, The World Bank, Baltimore, The Johns Hopkins University Press, 1990. Calculated from the "Country Pages" 228-229.

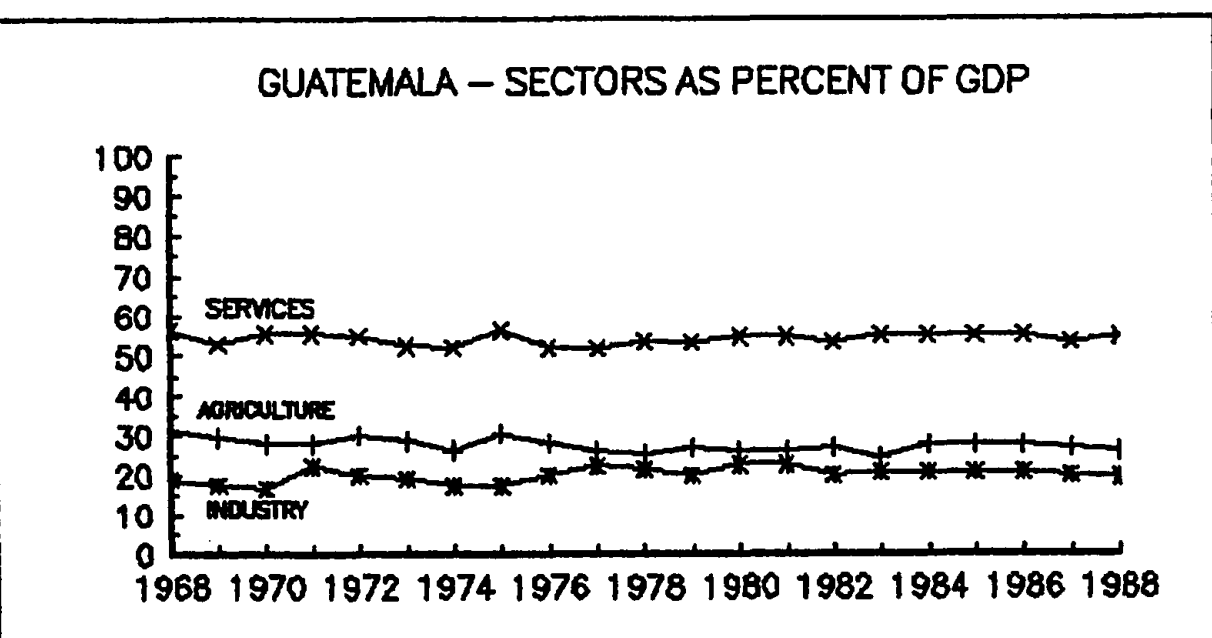

Figure 23. Guatemala: Economic Sectors as Percent of GDP. Source: World Tables - 1990, The World Bank, Baltimore, The Johns Hopkins University Press, 1990. Calculated from the "Country Pages" 272-273. 


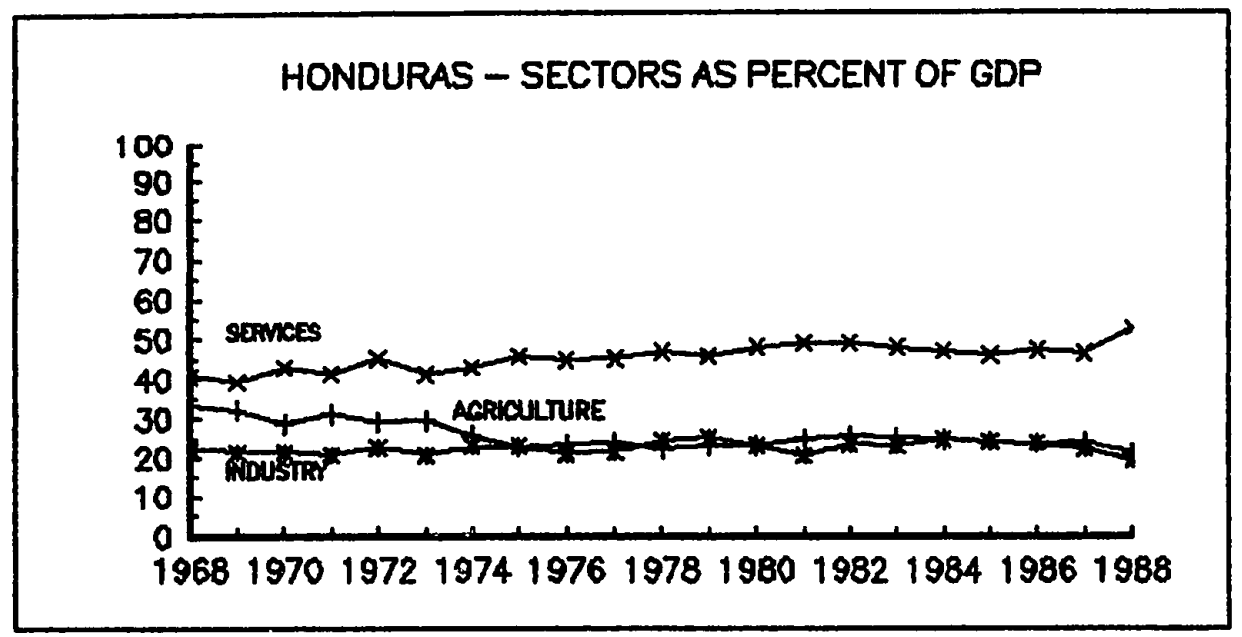

Figure 24. Honduras: Economic Sectors as Percent of GDP. Source: World Tables - 1990, The World Bank, Baltimore, The Johns Hopkins University Press, 1990. Calculated from the "Country Pages" 288-289.

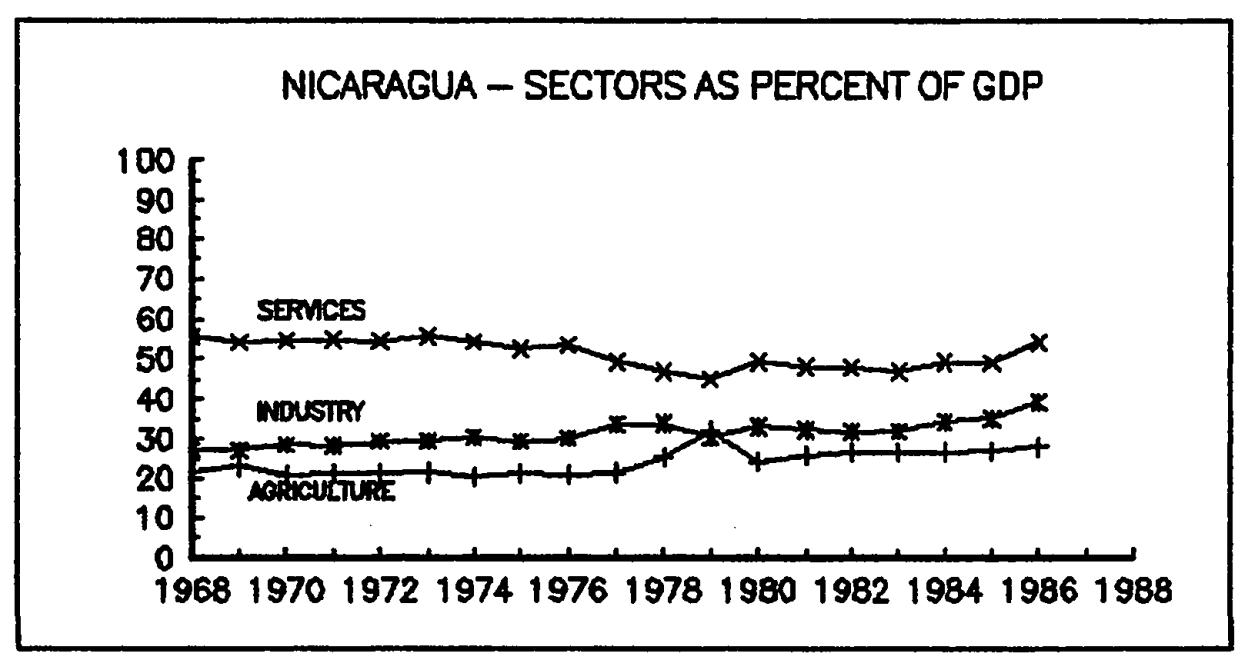

Figure 25. Nicaragua: Economic Sectors as Percent of GDP. Source: World Tables - 1990, The World Bank, Baltimore, The Johns Hopkins University Press, 1990. Calculated from the "Country Pages" 416-417.

through 25 illustrate that relationship for the five Central American nations for twenty years. Efforts to push the numbers back further than twenty years were abandoned due to the thorough inconsistency of the occasional individual country data. In any case it was apparent that earlier numbers differed little in pattern from those represented here. 
What is apparent with no more than a glance, is that for all five nations the pattern is virtually unchanged from the latter 1960s through the latter 1980 s. No structural change in the basic indicators occurred. These are important indicators regarding economic development from any point of view, but, in the Kuznetsian scheme they are fundamental.

A similarly aggregate indicator which is comparably suggestive is private consumption per capita. The data as presented by the World Bank is stated in terms of 1980 U.S. dollars, and for the purposes here, it was indexed at 1968 equal to 100 in order to readily compare the patterns for each nation (Figure 26, below). What is striking here is the dramatic similarity in pattern of the five Central American Nations.

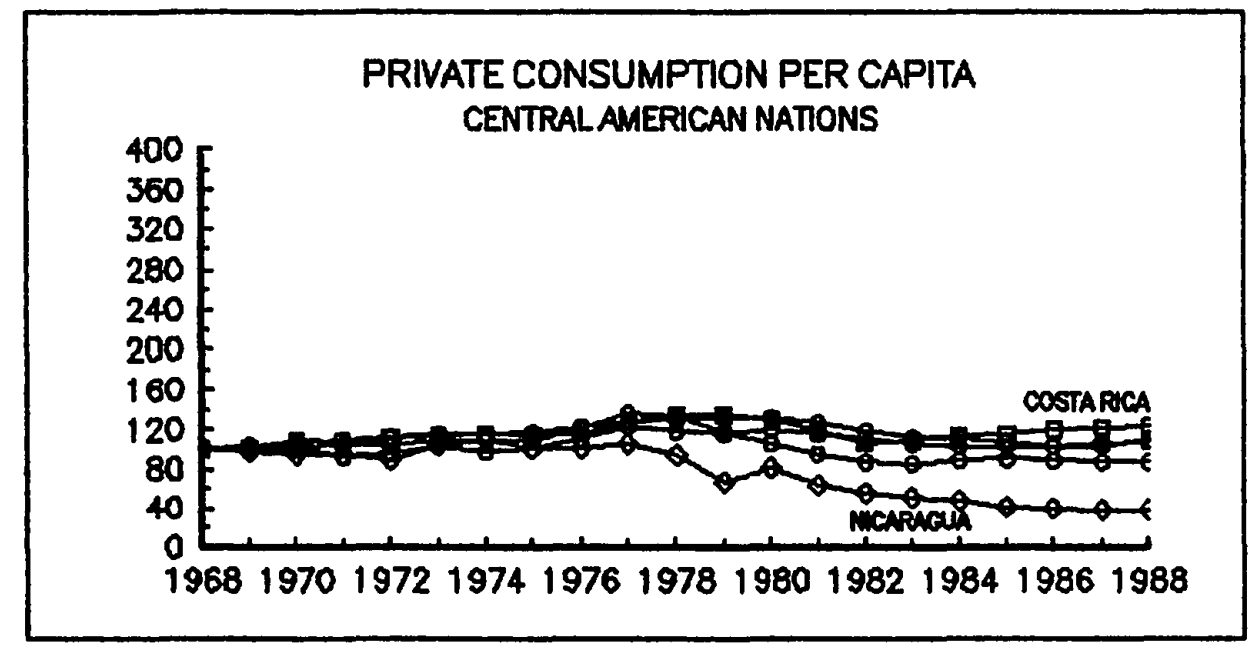

Figure 26. CANs: Private Consumption per Capita. Source: World Tables - 1990, The World Bank, Baltimore, The Johns Hopkins University Press, 1990. Topical Pages, Table 3, p. 10-11.

The related indicator, Private Consumption as a Percentage of GDP (Figure 27) shows almost no change in consumption as a part of GDP over the twenty crucial years. As indicated earlier, the expectation for a nation undergoing development toward modern economic growth is that while per capita consumption is increasing, consumption as a part of GDP is decreasing. In the case of the CANs (Figure 27) that 
figure actually shows an increase in two cases and a modest decrease in two others. One of the two showing a decrease is Nicaragua, where total output plummeted in the late 1970s and has changed little since. The other is Costa Rica, a nation which has proved to represent an interesting case of a mix of growth and development indicators.

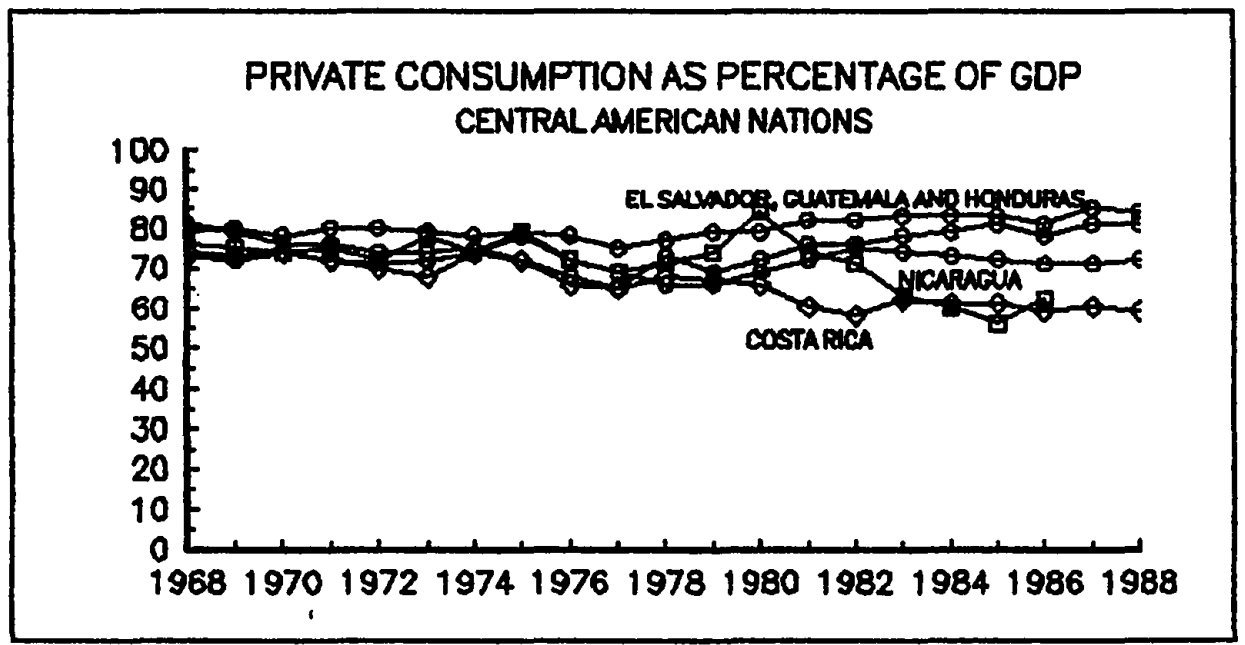

Figure 27. CANs: Private Consumption, Percentage of GDP. Source: World Tables - 1990, The World Bank, Baltimore, The Johns Hopkins University Press, 1990. Topical Pages, Table 3, p. 10-11.

Gross Domestic Savings as a percentage of GDP (Figure 28), another aggregate indicator, is one which can function as an indicator of development over time. Here for the first time we can highlight a pattern among the CANs which is apparent in a number of the other indicators as well. That is the distinction of Costa Rica from the other four nations in areas which relate to some unique policy decisions in the early post World War II period, as well as to the long-standing tradition of popular strength.

Figure 28 illustrates the fact that gross domestic savings ultimately decreased during the twenty year period for four of the five CANs. As with figure 10 above, the least squares lines have been added to clarify the trends in the data for the five nations. By comparison, the upward slant for this indicator for Taiwan and South Korea was discussed earlier in this Chapter. What is worth particular note here is that the only 
other upward slanting line among the seven nations is that of Costa Rica. All of the other four ended the period with savings as a lower percentage of GDP than that with which they started.

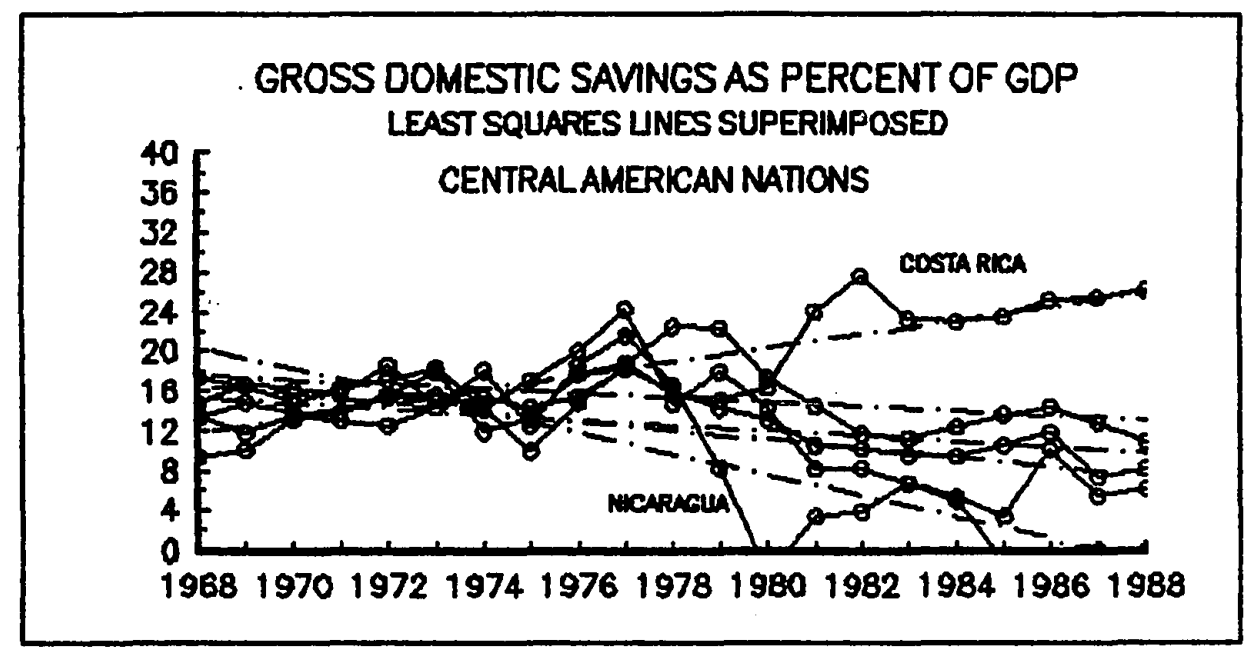

Figure 28. CANs: Gross Domestic Savings. Source: World Tables 1990, The World Bank, Baltimore, The Johns Hopkins University Press, 1990. Topical Pages, Table 14, p. 56-57.

The next indicator for which there is a consistent basis in data for all seven nations is Gross Domestic Investment (GDI). That indicator is being portrayed here as a percentage of GDP to create a proportional image (Figure 29). Because of the differences in GDI relative to GDP from one year to the next the graph looks rather complex. Least square lines have again been superimposed to highlight the trend over the period. Comparison with the graph for the ENICs in Chapter eight suggests also that the numbers for the ENICs are considerably higher for the entire period.

A simple alternative presentation of the data is the mean of each nation's GDI as a percentage of GDP. Listed below, the averages are within a few tenths of a percentage point of the same numbers.

Whereas South Korea and Taiwan had percentages in the upper twenties, the Central American Nations had approximately ten percentage points less for the twenty 


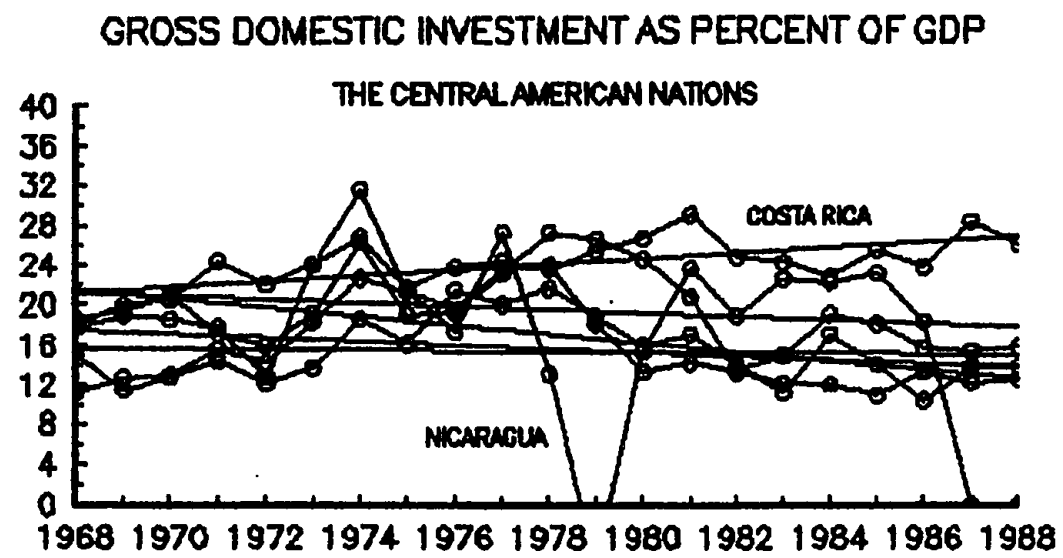

Figure 29. CANs: Gross Domestic Investment. Source: World Tables -1990, The World Bank, Baltimore, The Johns Hopkins University Press, 1990. Topical Pages, Table 13, p. 50-51.

years. Again Costa Rica is uniquely outside the pattern. For Costa Rica the numbers approximate the more successfully developing nations.

\section{GDI AS A PERCENTAGE OF GDP}

$\begin{array}{cc}\text { CANs } & \\ \text { El Salvador } & 15 \\ \text { Guatemala } & 15 \\ \text { Honduras } & 19 \\ \text { Nicaragua } & 17 \\ \text { Costa Rica } & 24 \\ \text { ENICs } & \\ \text { South Korea } & 28 \\ \text { Taiwan } & 26\end{array}$

Mean Values 1968-1988

GDI as percent of GDP

Another revealing way to slice the same data is to look at GDI per capita. The question here being, was investment in keeping with changes in the population. Figure 30 yields no surprises in the pattern thus far, but it clearly emphasizes the difference 
between the developing nations and the growing ones. The data for the graph is adjusted to 1980 U.S. dollars. The two ENICs clearly sustained a pattern of increasing

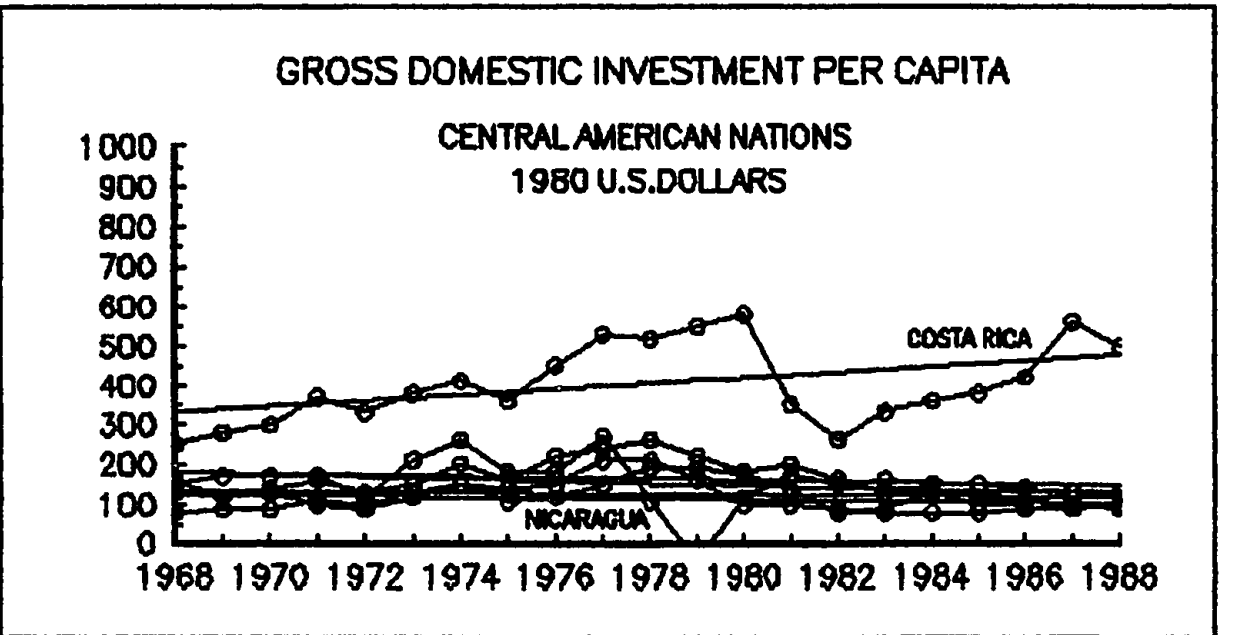

Figure 30. CANs: Gross Domestic Investment per Capita. Source: World Tables - 1990, The World Bank, Baltimore, The Johns Hopkins University Press, 1990. Topical Pages, Table 4, p. 14-15.

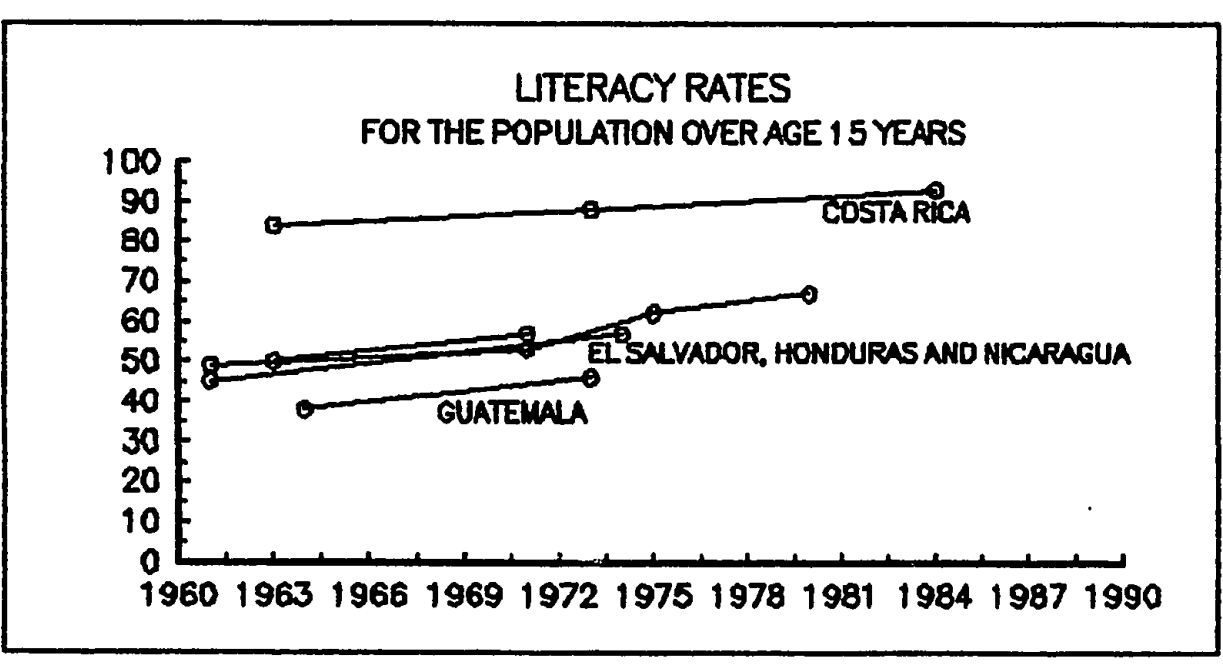

Figure 31. CANs: The Literacy Rates. Source: Compendium of Statistics on Illiteracy - 1990 Edition, Division of Statistics on Education, Office of Statistics, Paris, UNESCO, 1990. Part Two, Illiteracy by Country, Censuses Since 1960. 
per capita investment over the period. Costa Rica, again here, approximated the pattern of the ENICs until 1980 when the dominantly growth policies could no longer be sustained. The other four CANs generated a flat and even declining pattern of per capita investment over the two decades.

The final set of data which will be included in the mix is the set of literacy rates for the CANs. The availability of the elaborate set of information on literacy and education for Taiwan has already been noted as important to the development process and to development policy. On the other hand, the most striking thing about the literacy data for the CANs is the paucity of it. Figure 31 displays the only useful data which is available for all five of the nations. It is based on that collected by the United Nations Educational, Scientific and Cultural Organization (UNESCO).

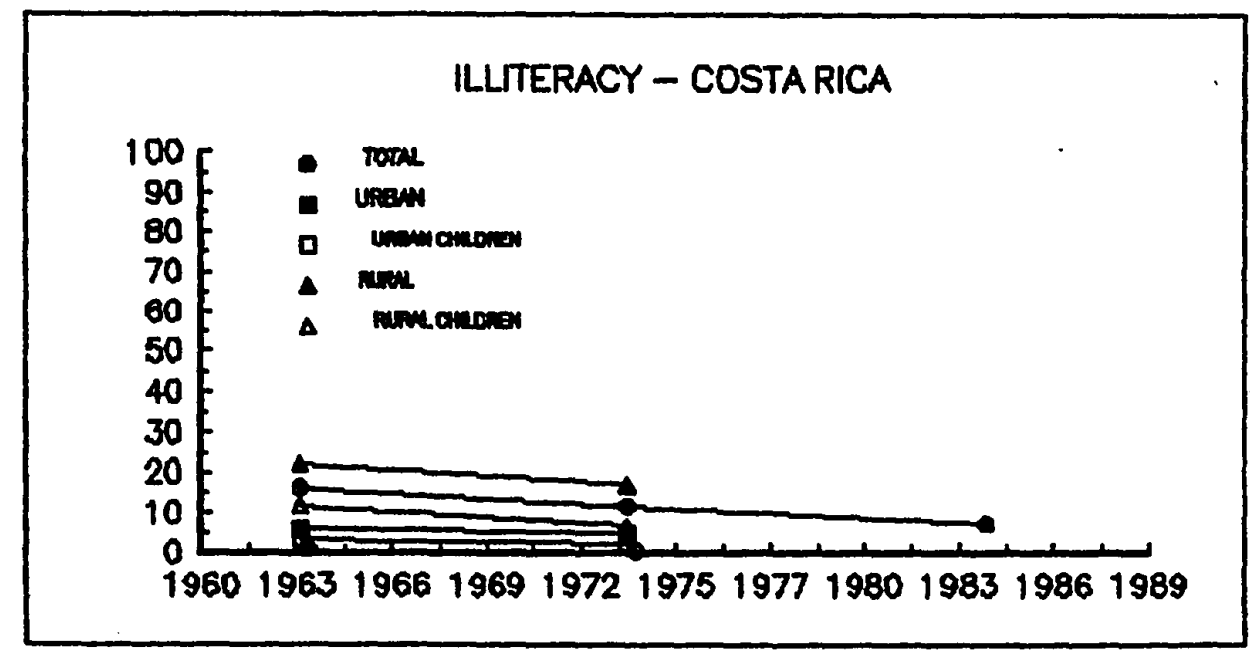

Figure 32. Costa Rica: The Illiteracy Rates. Source: Compendium of Statistics on Illiteracy - 1990 Edition, Division of Statistics on Education, Office of Statistics, Paris, UNESCO, 1990. Part Two, Illiteracy by Country, Censuses Since 1960.

Costa Rica has collected and used literacy data for decades. This is in keeping with the substantial emphasis on education which has been an important element of popular consensus on national policy for more than forty years now. But none of the 
other CANs has any education related data which is useful either for comparison or for policy guidance. For those nations such data is as scarce as is information on income distribution.

Considering the decades of emphasis on education in Costa Rica it comes as no surprise that the literacy rate in Costa Rica is at least as high as that in the two rapidly developing nations. On the other hand, the literacy rates in the other four CANs starts low - 50 percent or less - and rises only slightly during the critical years of economic growth. This is a function of decisions made in those four nations to spend little on schooling for the population in general. Some government funds in the other four CANs were spent in urban settings, and considerable assistance was available for use by the already well placed.

A more revealing pattern emerges in this realm with more detailed data. Besides the national totals, the UNESCO surveys also distinguish between urban and rural populations and between school age children and adults. Figure 32 portrays the results of three surveys for Costa Rica. It is notable that by 1963 the illiteracy rates for the entire population were already very low. The rates for all segments of the population then continue to improve during the subsequent two decades. It is also predictable that the rates for children are better than those for the adults, and the rates for the urban population are better than those for the rural areas.

In all of the CANs a large part of the rural population continues to live in subsistence conditions and in those parts of the nations there is little or no infrastructure at all. In those areas education appropriately takes the form of subsistence skills.

The only other of the CANs for which UNESCO has yet prepared data beyond the early 1970s is El Salvador. The data on El Salvador in Figure 33 serves to illustrate the pattern which is consistent with the other three CANs, except that by 
going beyond the mid-1970s it also suggests the emergence of a trend with unhappy consequences for the economic future of the nations in the region. From 1975 to 1980

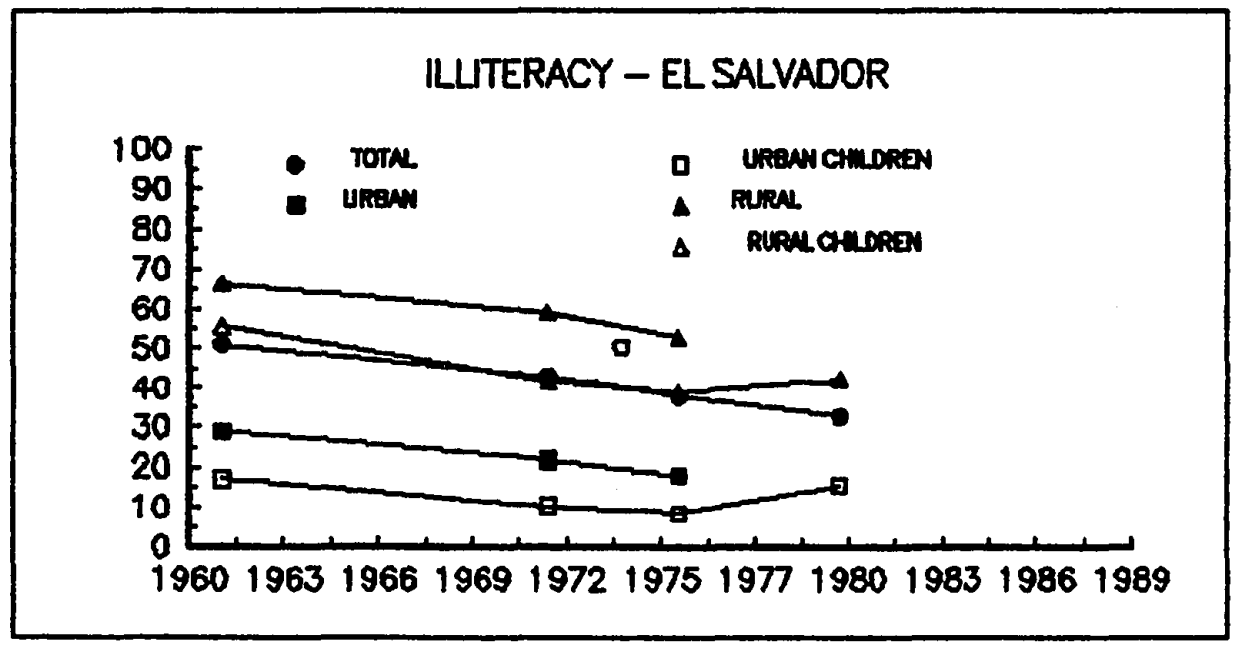

Figure 33. El Salvador: The Illiteracy Rates. Source: Compendium of Statistics on Illiteracy - 1990 Edition, Division of Statistics on Education, Office of Statistics, Paris, UNESCO, 1990. Part Two, Illiteracy by Country, Censuses Since 1960.

the rate of illiteracy actually increased substantially in El Salvador for both rural and urban Children. This trend emerged during the latter part of the period of economic 'growth' for El Salvador. It is generally regarded that it was at the turn of the decade of the 1970s to the 1980s that the 'crisis', the collapse of the political and economic contract, emerged. That increase in the rate of illiteracy for children reflects policy decisions taken at the national level with respect to whether or not such "social services" could be sustained. Education was never seen as a 'growth' priority. Education was regarded as a luxury when development, structural change, was seen as a threat rather than as a goal. 


\section{CHAPTER IX}

\section{ECONOMIC GROWTH VERSUS ECONOMIC DEVELOPMENT IN THE SEVEN NATIONS}

\section{THE INDICATORS}

Taken together, the data presented in the preceding chapter generates a picture of consistent distinction between the ENICs and the CANs. The indicators, based on the Kuznetsian expectations of an economy which is developing toward modern economic growth, represent the key structural indicators within the context of the aggregate indicator, gross domestic product (GDP).

The latter indicator, GDP, taken by itself, is an indicator of growth. This would simply imply that the aggregate product of the nation is increasing, or failing to increase, aside from any considerations of structural change. ${ }^{1}$ Because growth without structural adaptation is a phenomenon which is limited by the current structure, a sustained type of growth requires the structural adaptation the likes of which is anticipated by the Kuznetsian scheme. Lacking the structural adaptation, an underdeveloped economy would not be expected to sustain substantial growth over the longer term suggested in Kuznets' framework, a period of twenty or thirty years.

The requirement of structural adaptation in the context of growth is a phenomenon which is recognized in most fields. The fact that a given structure limits

\footnotetext{
1 It is worth noting here that for Kuznets the pattern of simple aggregate increase in production for an tconomy does not indicate modern economic growth. That coneept requires "the interplay between sustained rises in population and rises in economic performance substantial enough to assure (a sustained) upward trend in per capita product." Simon Kuznets. Moderm Economic Growth: Rate Siructure and Snread. New Haven. Yale University Press. 1966. page 20.
} 
the growth of anything is to be found in discussions by biologists, meteorologists, chemists, organization theorists, and students of a long list of disciplines. In economics Kenneth Boulding is one who has discussed the issue extensively and in depth. ${ }^{2}$ Michael Todaro, in his third world development text, recognizes the phenomenon with the statement, "Development must, therefore, be concieved of as a multidimensional process involving major changes in social structures...as well as the acceleration of economic growth."3 Joseph Schumpeter, as well, puts considerable emphasis on the need to expect structural change with growth. In his Theory of Economic Development he states that economic development involves "that kind of change arising from within the system which so displaces its equilibrium point that the new one cannot be reached from the old one by infinitesimal steps. Add successively as many mail coaches as you please, you will never get a railway thereby." 4

On the most general level, then, the structural data is important to the consideration of whether or not a growing economy is undergoing a sustained expansion. In Kuznets' terms, the question is whether the underdeveloped economy is undergoing a transition toward modern economic growth. In the Kuznetsian scheme the nature of the output must change, the use of that output must change, and the quality and nature of the input must change.

When the structural data is Assembled for the two groups of economies the distinction between them becomes clear. While the ENICs could serve as illustrations of the Kuznetsian expectations for transition toward modern economic growth, the CANs represent successful growth, especially through the 1960s and 1970s, without the

2 It would be pointless to list the long list of publications in which Boulding has discussed this familiar issue. A few examples, however, would include. Kenneth Boukding. "Toward A General Theory Of Economic Growth". Canadian Journal of Economies and Political Science, Volume 19, August 1953, pages 326-340; also Boulding's Ecodynamies. Sage Publications. Beverly Hills. 1978; and Human Betlernient. Sage Publications. Beveriy Hills. 1985.

3 Michael Todarn, Economic Develonment in the Third World. Fourd Edition. Longman. New York. 1989, page 88.

4 Joseph A. Schumpeler. The Theory of Economic Develonnzent. Transaction Books. New Brunswick. 1983, page 64. 
structural transition to be expected of development. The one aberrant case among the five CANs is Costa Rica. some of the indicators for Costa Rica more nearly approximate the expectations of development. This is as might be expected given the number of post-World War II policy decisions which, intentionally or not, supported a tendency toward development.

\section{THE PATTERNS}

The indicators for the ENICs illustrate a clear pattern of change in the economic structure of both countries. In Figures 4 and 5 it is clear that there was a rapid rate of growth in both the total and the per capita product for the two countries. At the same time, the anticipated shift in structure away from agriculture and toward industry is to be seen in the plots of the three sectors for each nation in Figures 6 and 7.

Private Consumption per Capita (Figure 8) also increased continuously and rapidly for the ENICs, as did Gross Domestic Savings (GDS) as a percentage of GDP (Figure 10). For both nations the GDS increased rapidly from less than 15 percent of GDP to well into the 20 and 30 percent realms which Kuznets found to be characteristic of developing economies.

As is to be anticipated, given the relatively high level of savings, Gross Domestic Investment (GDI) is also well within the range of percentage of GDP (Figure 12) which the expectations of modern economic growth would have us look for. Both the mean and the average rates are in the upper twenty percent for both of the ENICs. GDI per capita (Figure 11) also increased at a steady rate for the two countries, with some secondary patterns which were discussed above.

The literacy indicators (Figures 13 and 14) for both countries again fall neatly within the pattern to be expected of economies well engaged in modern economic growth. Taiwan shows an exemplory high level of literacy in Figure 13 and as 
described in chapter 8, that data is the tip of an iceberg of data on schooling and literacy which documents four decades of major investment in education of the population. ${ }^{5}$ Although the UNESCO generated data is sparse for South Korea, the pattern is unmistakable. In the ten years documented by the United Nations agency the literacy rate had already reached a level approximating that for the developed nations.

The economic growth of the CANs presents a pattern in the indicators which is consistent and striking in its similarity among the five nations. Costa Rica is the only one of the five which shows some distinction. The distinction is understandable given the history of somewhat more democratic political and economic decisionmaking which is associated with that country.

The important differences which appear for Costa Rica include the realms of education, where the decision was made in the early 1950s to pursue universal education for the population; social security, where law supports benefits for the employed and to a lesser extent for the population as a whole; and in a different kind of security for the population, assurance that the military cannot enforce policy decisions by the national leadership because there is no military.

The GDP data in Figures 16 through 20 illustrates the fact that aggregate economic increase took place through the decades of the 1960s and the 1970s. GDP increased substantially in all of the nations during those years. GDP per Capita, however, increased relatively little, and if the data were available it is likely to show that income distribution worsened during the period. 6

\footnotetext{
5 A source of elaborate data on education and literacy in Taiwan is the manual mentioned earlier in this chapter, Council for Economic Planning and Development. Taiwan Statistical Data Bonk - 1990. Rupublic of China. 1991.

${ }^{6}$ The smattering of data on accunulation and movement of wealth and the eonsiderable aneedotal information which is available unanymously supports the observation that income distribution worsened.
} 
The representations of the three key economic sectors for the CANs, Figures 21 to 25 , is likewise striking in its consistency among the five nations and in its illustration of the fact that no structural change took place. Keeping in mind that GDP for all five nations rose steadily for twenty years, then fell dramatically in absolute terms, it is notable that none of the sectoral data shows a response of any sort.

At just the point of the expulsion of Somoza by the Sandinistas in Nicaragua the three sectors show a substantial 'flinch'. Specifically what is shown by the graph is that the services sector experiences a substantial drop in response to the major civic disruptions, industry experiences a lesser drop, agriculture shows a sharp and temporary jump in percentage of GDP as a result. By the following year both services and industry are up and agriculture is back to roughly where it was the previous year. Regardless of the 'flinch', the Nicaraguan economy shows no change in structure whatsoever in the twenty years.

Unlike the pattern of structural change shown by two ENIC nations, the other four CANs show little of significance with respect to development. It is worth noting that the graphs indicate a slight increase in industry as a percentage of GDP for Costa Rica in the latter 1970s, with no subsequent change. For Honduras, on the other hand, a decrease in agriculture in the mid 1970s was associated with a comparable increase in the services sector. This appears to have represented a less than positive superficial change in structure which was sustained through the 1980s.

The graph of private consumption per capita, Figure 26, extends the pattern created by the previous data in several respects. As distinct from the ENICs, all five of the CANs display a pattern of slight increases over the first ten years followed by another ten years of decrease to near or below 1968 levels. This pattern follows that of GDP per capita very closely in the CANs and reflects the fact that the sectoral structures showed no change during the period. 
Whereas with the ENICs the economies displayed the important development of increased production and consumption by the population as a whole, the CANs showed almost no change in that regard. Among the CANs the increase in consumption tended to stay within the narrow range of consumers who benefitted from the economic growth, that being the elite and those who functioned to support the ongoing state of the economy. It was not allocated to those who would support a change in the structure of the economy. That is, whereas among the ENICs an important structural development was the inclusion into the economy of the large percentage of the population which was previously either external or marginally involved, among the CANs neither the consumption nor the production activities were extended to include a larger range of the population. In an important sense, this was a 'comparative advantage' which was ignored by the CANs, due to the ideological constraints on the definitions of comparative advantage which was discussed in earlier chapters.

Figure 28, Gross Domestic Savings, portrays essentially the difference between total production and the consumption of it. Though Costa Rica shows an increasing percentage of GDP being saved over the twenty years, the other four CANs show a decreasing percentage going to savings. For those other four, while GDP was increasing through the latter 1970 s, the part of it which was set aside from consumption did not increase. When put together with other indicators this one becomes even more meaningful. There was no change among the key sectors, savings continued to be a relatively low percentage of GDP, and the related figure, investment as a percentage of GDP (see Figure 29 and the mean values), remains similarly low for the entire period.

When the domestic investment per capita figures are consulted (Figure 30) the observations regarding lack of change are reinforced even further. While the ENICs, and to a considerable extent Costa Rica as well, generated an increasing investment per capita as GDP increased, the four CANs concluded the twenty year period with the 
same per capita investment as that of twenty years earlier. A slight increase in the latter years (the 1970s) of the 'growth' period was completely erased during the crisis years.

The final element of the pattern, an important development indicator, is the change in the rate of Illiteracy. A substantially illiterate population is incapable of participating adequately in the process of modern economic growth. Among other aspects, the many facets of industrialization, be it agriculture, manufacture or services, require a literate workforce. Thus, inevitably, an economic development undertaking must deal with the problem of increasing literacy early in the process.

An important indicator of development, then, is the changing level of literacy over a several year period. But what is particularly telling, especially over the shorter run of a few years, is the breakdown within the total literacy level. That is, the distinction between the urban and rural populations and the child and adult populations is important for policy guidance.

Child literacy will likely, though not necessarily, be the leading edge of the process, and within that category, urban children would be expected to represent a relatively high gain in literacy rather quickly. This represents the general assumption having to do with ease of access for the urban population and a higher value in literacy for urban economic endeavors. But development policy makers may well determine that investment in rural literacy would generate a good medium term payoff. The example of Taiwan serves well in that respect. A determined effort was made at the beginning of the development effort to include the rural as well as the urban population in the national education policy.

Four of the CANs, consistent with the emphasis on growth of the economy saw little direct benefit in literacy for the population as a whole. In fact, education, while not ignored, is considered to be a social service, not an integral part of economic 
growth. Thus, in Figure 33 above, the increase in illiteracy in children between 1975 and 1980 in El Salvador reflects the cutbacks in the already minimal services which became universal in Central America during the 1980s.

A summary representation of the indicators for the seven nations is given in the figures below. The question to be answered is whether or not the indicators correspond to the expectations of Kuznets modern economic growth.

The first two indicators, GDP and GDP per Capita, though necessary to the full pattern of development indicators, are growth indicators when taken alone.They are necessary but not sufficient in the package of development indicators. The following indicators, those representing the sectors, the use of output, and literacy, contain the range of development indicators used in this study. These are the structural indicators. Each indicator is evaluated individually as discussed previously in this chapter and in chapter eight, all in keeping with the expectations drawn from Kuznets mid-century statistical studies.

The smoothed data from chapter 8 is here compared to the Expected Pattern of Indicators as presented in chapter 4 . Figure 34 reproduces the expected pattern, and those following contain the statistics of the seven nations represented as trend lines. The data in each case has been smoothed by means of a least squares technique for the sake of clarity. 7

The GDP and GDP per capita panels (Figures 35 and 36) highlight the fact that while the ENICs present a pattern in keeping with the Kuznetsian expectations, the CANs do not. Even though for the CANs the GDP alone appears to increase slightly during the period, due to the smoothing of the years of the collapse with the earlier years of growth, GDP per capita makes a very poor showing throughout. The panels

\footnotetext{
7 Least squares calculation is a standard statistical method for establishing trends in linear data. The method for calculation of the trend lines can be found in any basic statistics text.
} 


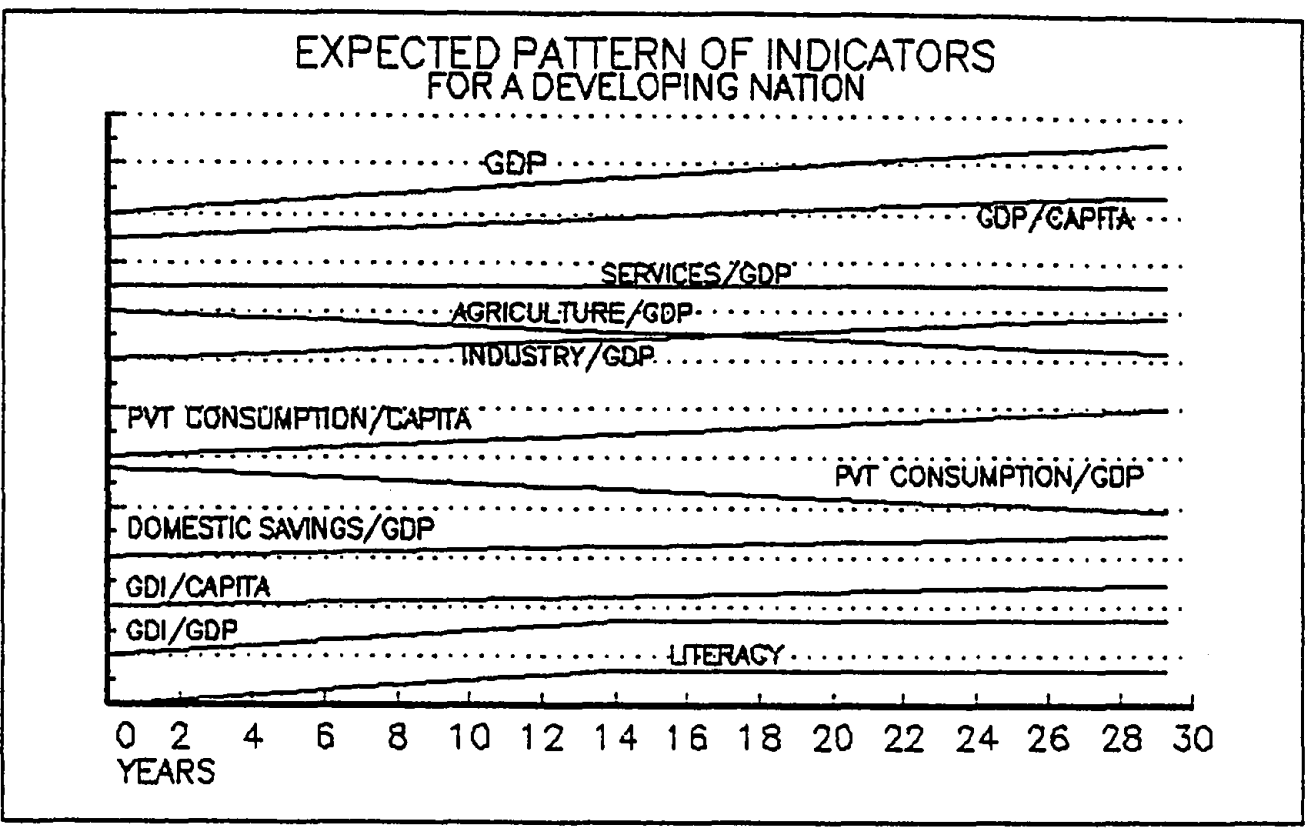

Figure 34. Expected Pattern of Indicators for a Developing Nation.

with the three sectors (Figures 37 and 38), also make clear that the ENICs developed in accord with the Kuznetsian expectations, while the CANs remained essentially untouched by the limited growth which took place during the period.

Private consumption per capita did not increase for the CANs, while it did for the ENICs (Figure 40). And private consumption as a part of GDP simply stayed high

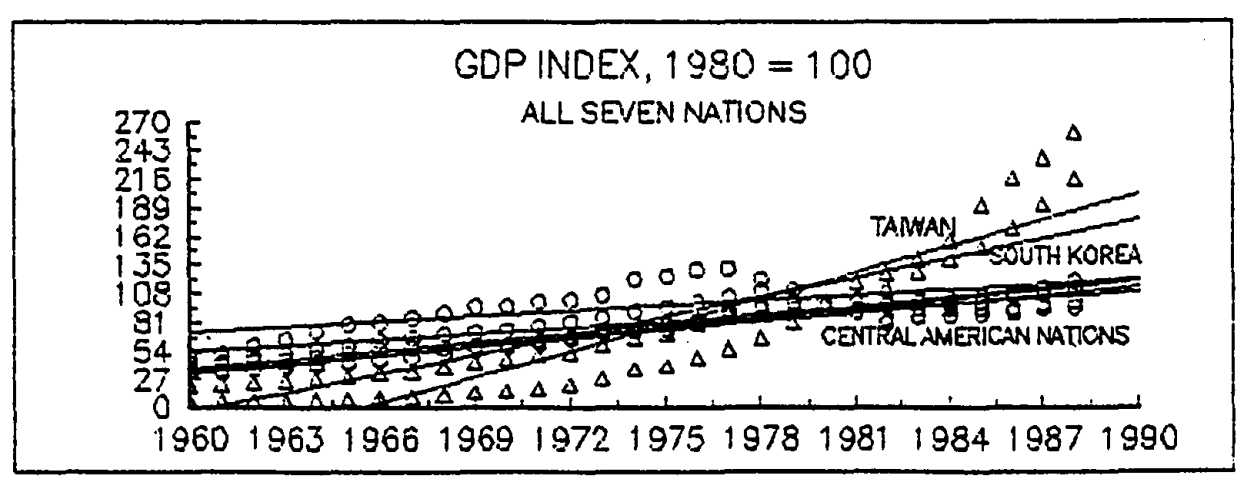

Figure 35. Gross Domestic Product. 


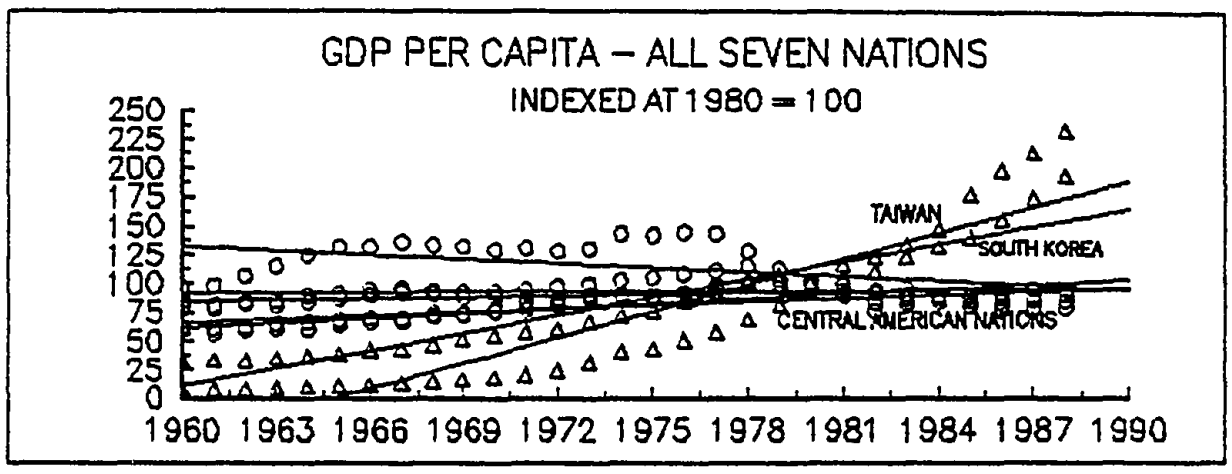

Figure 36. Gross Domestic Product per Capita.

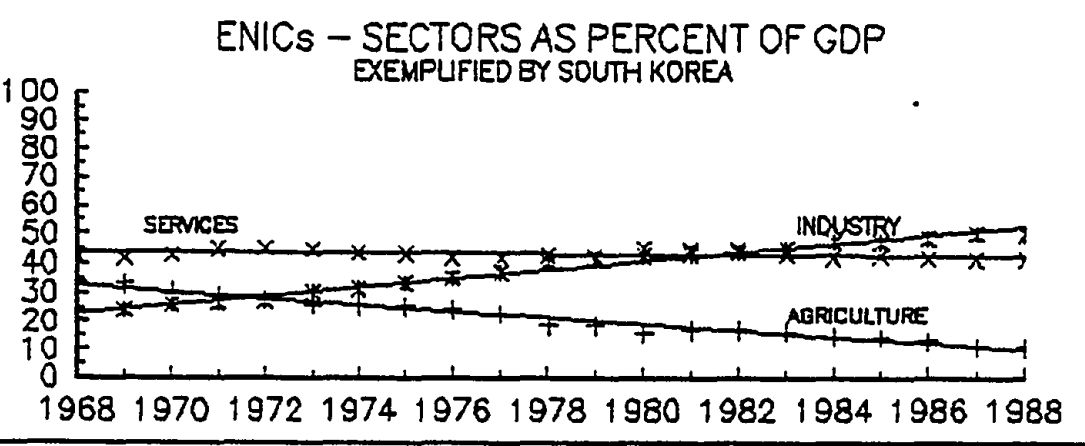

Figure 37. Three Sectors as Percentage of GDP - ENICs.

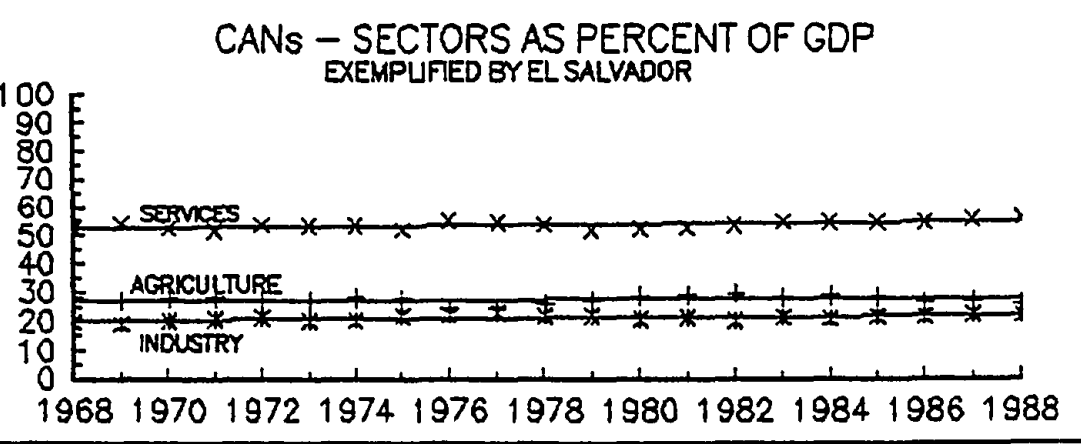

Figure 38. Three Sectors as Percentage of GDP - CANs. 


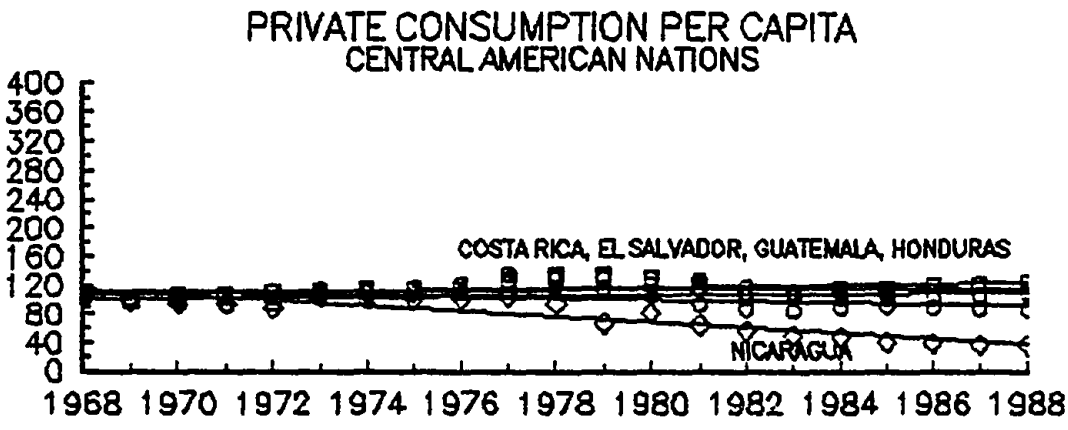

Figure 39. Private Consumption per Capita - CANs.

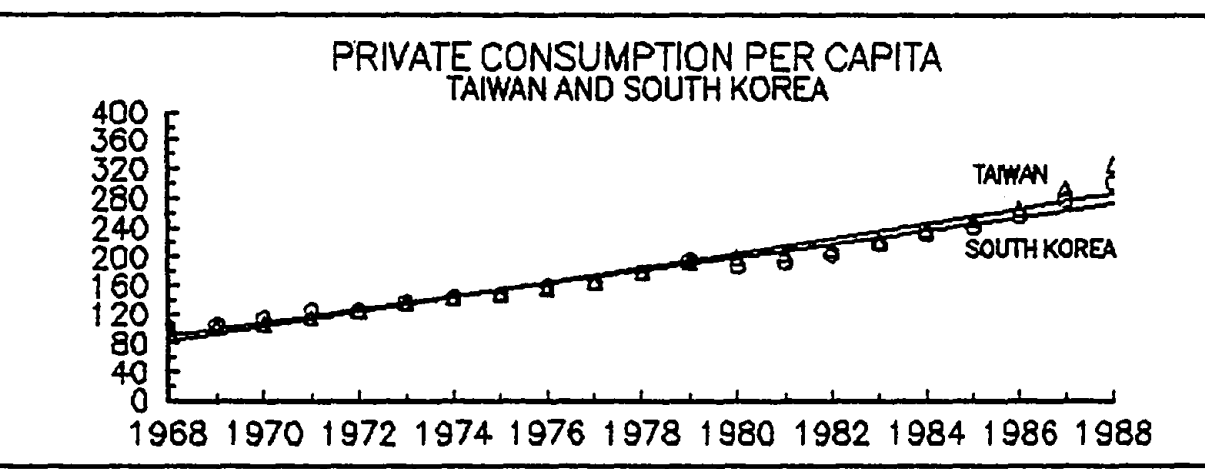

Figure 40. Private Consumption per Capita - ENICs.

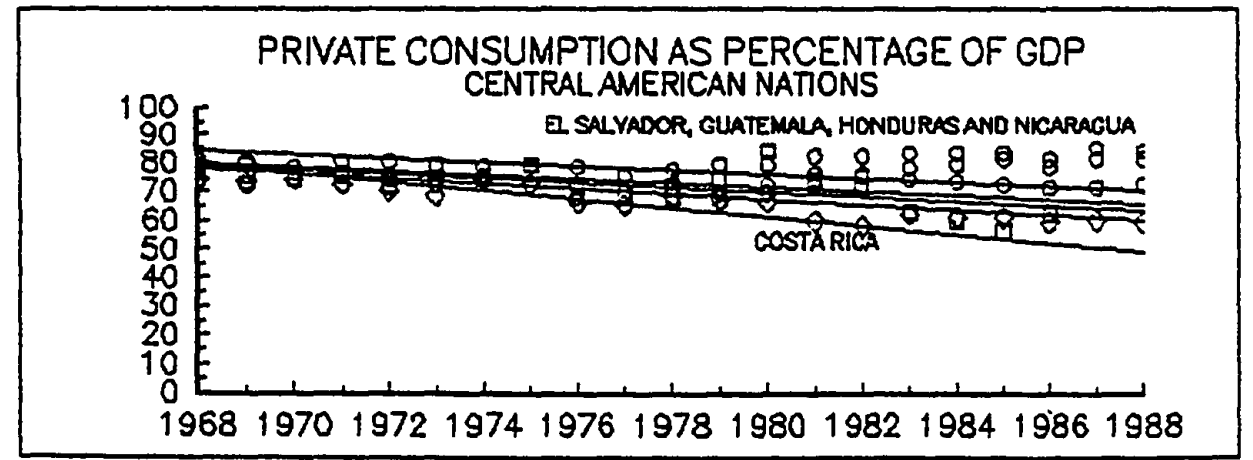

Figure 41. Private Consumption as Percentage of GDP - CANs. 


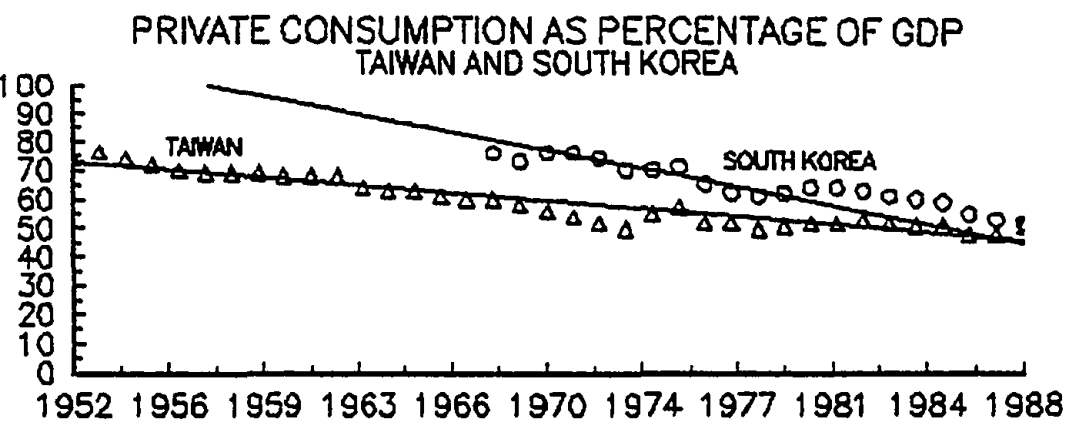

Figure 42. Private Consumption as Percentage of GDP - ENICs.

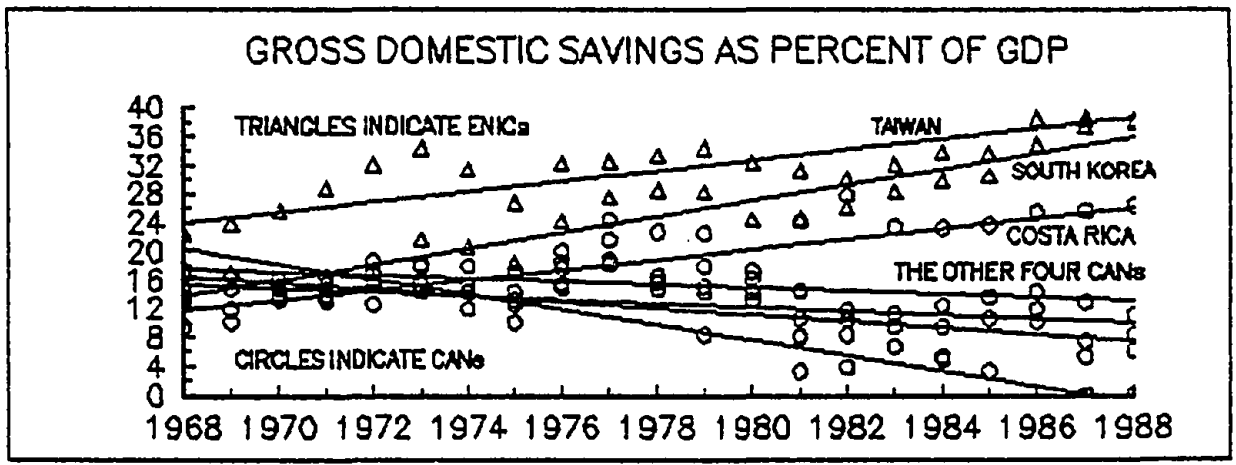

Figure 43. Gross Domestic Savings as Percent of GDP.

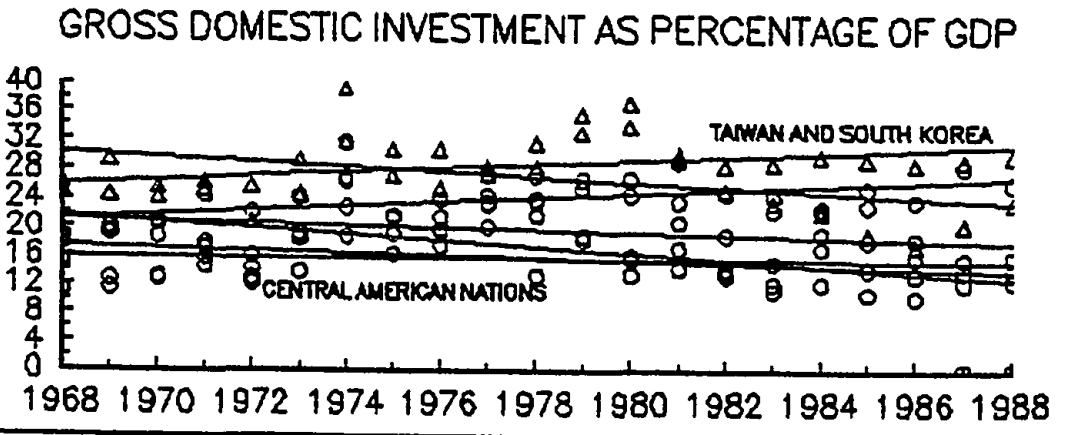

Figure 44. Gross Domestic Investment as Percent of GDP. 


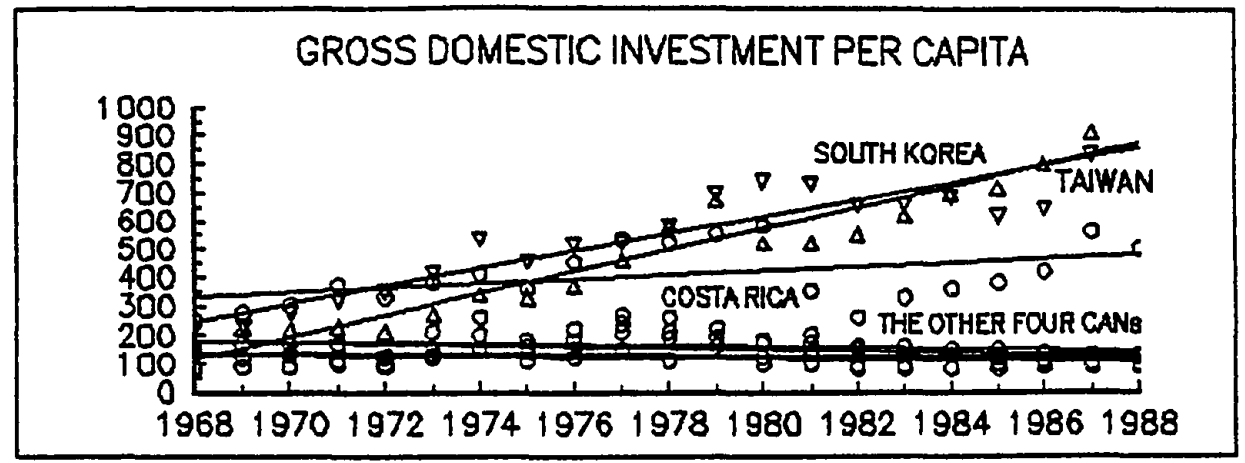

Figure 45. Gross Domestic Investment per Capita.

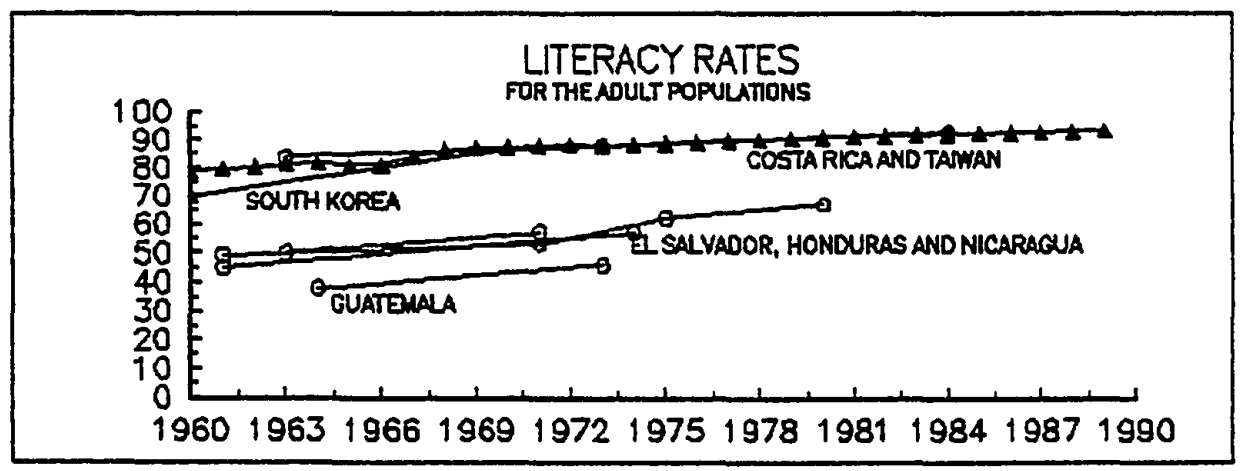

Figure 46. Adult Literacy Rates.

for the CANs (Figure 41) while it decreased in keeping with the expectations for a developing economy for the ENICs (Figure 42). With domestic savings as well (Figure 43) the development related increase is clear for the ENICs, while the CANs, with the exception of Costa Rica, show an overall decrease.

Gross domestic investment (GDI) increased to over $25 \%$ of GDP for the ENICs (Figure 44), as is consistent with Kuznets' expectations for development, while for the CANs it actually decreased from the already low level at the-beginning of the period. At the same time, GDI per capita (Figure 45) for the ENICs increased by three to four times the initial level. In the CANs, on the other hand, GDI per capita continued 
unchanged for all the five nations except Costa Rica, which increased slightly. For Costa Rica the increase was approximately one half the initial level.

Literacy, the final indicator, is poorly represented in Figure 34 . The expectation, however, is that literacy climb rather quickly to arrive at a rate of approximately $90 \%$ for the adult population and that it happen within a decade or two of the initiation of the development process. It is clear in Figure 46 that the ENICs achieved the goal early in the process, and it is equally clear that the CANs did not. With the exception of Costa Rica, the literacy rate for the CANs is well below the $90 \%$ level, and it is little above the rates from the middle part of the century.

One of the few points at which indicators appear, even on the surface, to disagree with the expectations of modern economic growth is with respect to gross domestic investment for Taiwan. It is worth noting that while the curves for both nations appear relatively flat rather than increasing as expected, the fact is that both nations during that twenty year period are already well within the expectations for investment for a developing nation. The mean rates for GDI to GDP during that period is 28 percent for South Korea and 26 percent for Taiwan. Both nations showed the increase from the ten to fifteen percent levels of investment during the 1950 s and early 1960s.

It is clear that the ENICs both fit the profile of the nation in transition toward modern economic growth according to the findings of Kuznets. These are nations in sustained development, not nations with economies which are merely growing in size.

The differences in the patterns with respect to the two sets of nations is striking. Costa Rica is the only nation of the five which shows patterns in the indicators anywhere between fully conforming to the pattern of development and completely failing to conform to the pattern. For the five CANs, even the growth indicators, GDP and GDP per Capita, when examined over the full thirty year period, indicate poor 
growth performance. Taken alone, much of the first twenty years of the period for the CANs, on the other hand, suggests strong and continuous growth for the five. Even GDP per Capita increased somewhat during that period for four of the five.

It is the performance with respect to both GDP and GDP per Capita as of the latter 1970s which tells the compelling story of the difference between economic growth and economic development for the underdeveloped nations. Had we examined only the years from 1960 to the latter 1970s we would have been impressed by the growth, as indeed many were. As development indicators, however, they depart from conformation in the latter 1970 s when the growth collapsed and was followed by some years of contraction. In three of the five cases, ten years after the collapse the nations were still below the level of GDP gained ten years earlier. In Costa Rica and Honduras a return to the pre-collapse levels occurred in seven and four years respectively. In none of the five cases, though, did GDP per Capita return to its former level, and only in Costa Rica has it increased at all from the crash level of the early 1980s.

Among the three sectors in each of the CANs (Figure 38) there is no indication of structural change. Through the period of satisfying GDP growth in the 1960s and 1970 s there is almost no hint of either an increase in industry or a decrease in agriculture as a part of GDP. For Nicaragua the single year 'flinch' in the pattern in the three sectors (Figure 25) occurs in 1979, just the point of the Sandinista revolution. Immediately thereafter the economy returns to the pattern of two years eariier though on a continuously lower level of GDP.

A couple of other minor patterns within the major monotonous sectoral one is that in Costa Rica (Figure 21) there actually is a small decrease in agriculture as a percentage of GDP, together with a minor increase in industry. There actually was, in other words, a small change in the structure of the economy in the direction of industrialization. In Honduras as well, agriculture decreases several percentage points 
in the early part of the period, but paradoxically it seems to have been replaced as a part of GDP by the services sector. This is not a positive change, particularly given the constant increase in total external debt over the same period.

Private consumption per capita (Figure 26) actually decreases for two of the nations, stays the same for two of them and increases slightly for the Costa Ricans. Interestingly, consumption increases slightly just before and during the collapse of GDP in all of the nations other than Nicaragua, where the large decrease in consumption continues after the arrival of the Sandinistas.

Private Consumption as a percentage of GDP reinforces the per capita observations. Here there is little significant change over the two decades, but there are some interesting minor patterns. In two cases consumption as a part of GDP actually increases over the period, in one there is no change and in the case of Costa Rica there is a decrease of twelve percent. This latter is in keeping with the expectations of a development transition, and it is consistent with the increase in gross domestic savings as a percentage of GDP (Figure 28) for Costa Rica. Though all four of the other five nations show a decrease in the amount of savings in GDP over the period, Costa Rica shows an increase of more than ten percent.

Likewise, while gross domestic investment (GDI) per capita (Figure 30) decreases slightly for the other four CANs, Costa Rica shows a small increase despite the major dip in response to the collapse of GDP. GDI as a percentage of GDP shows an entirely consistent pattern for the five nations. While GDI increases significantly as a part of GDP for Costa Rica, it starts low and ends even lower for the other four nations. For all of the other four CANs investment climbed somewhat prior to the collapse, but the decline from that point took investment as a part of GDP to a point where it was consistently even lower than it had been at the beginning of the period. The mean values for GDI as a percentage of GDP confirm the patterns on the graphs. 
The mean value for Costa Rica is 24 percent, a value which locates the country among those in the developing realm according to Kuznets' findings. The value for the other four is 15 to 19 percent for the period. Those values, according to Kuznets, do not suggest a development pattern.

Though the data for literacy among the CANs is sparse relative to the elaborate data collected by the ENICs, it is consistent with the other observations. Costa Rica, again, stands out among the four as having achieved a rate of literacy which, in this case, would be entirely supportive of the transition toward modern economic growth. The background for this accomplishment was discussed in earlier chapters.

Literacy for the other four nations was considered to be a luxury, not a requisite investment. For that reason literacy improved little, even during the period of satisfactory growth, generally 1960 to the late 1970 s. The detailed graph for illiteracy for El Salvador (Figure 33) indicates that even the unimpressive decrease in illiteracy rates (increase in literacy) from 1960 to 1975 has reversed. The rates of illiteracy for children, both urban and rural, has worsened substantially. In the case of urban children the rate worsened from 1975 to 1980 by just the amount it had improved over the preceding fifteen years. This data is especially meaningful in that the rate for urban children is considered to be the crucial one. It is urban children who are most likely over the succeeding years to fill the needs of increasing industrialization.

Leaving Costa Rica aside, it is worth noting that none of the other four Central American nations show a consistent sign of economic development during the decades following World War II. Clearly simple growth is there in the early part of the period. For all of them there is the display of economic growth about which writers both during and since that time have waxed enthusiastic. But in all five nations the growth was not sustainable and it was not matched by GDP per Capita. For all five of the nations there was no change in the structure, and for four of them, there was 
inadequate savings and investment as well. It is the latter concern, that of investment, which relates to the failure to invest in education, and thus, to invest in an important component of modern economic growth. 


\section{CHAPTER X}

\section{STRUCTURAL CHANGE}

\section{GROWTH IN CENTRAL AMERICA, DEVELOPMENT IN EAST ASIA}

The indicators used in this study made clear distinctions between the two groups of nations. As discussed in Chapter nine, for all of the indicators the ENICs illustrated the expectations for a nation undergoing transition to modern economic growth. Both nations have increased total output in a sustained manner while at the same time accomplishing a consistent increase in per capita output. At the same time the data illustrated a substantial decrease in the agricultural sector which was mirrored in a comparable increase in industrial production, with little change in the services sector.

Private consumption per capita increased for the ENICs while the same figure as a percentage of GDP decreased. This can happen only if total output is increasing at a rate which is sufficiently faster than population growth that a larger amount of output can be allocated to both private consumption and investment. In both of the ENICs the part of GDP allocated to investment since the middle of the century increased to over $25 \%$ of the total, a figure which the studies by Simon Kuznets suggested was necessary to sustained growth. Given the consumption and investment indicators it comes as no surprise that domestic savings in both countries increased during the period.

The literacy figures confirm the large amount of data and anecdotal material regarding the investment in training and education by the ENICs. Paul Kuznets describes the investment in education in South Korea as averaging $9 \%$ of GNP for the ten years 1966 to 1975 . At present both Taiwan and South Korea are emphasizing "knowledge intensive" and "skill intensive" production, thus increasing the 
'comparative advantage' which was created through earlier investment in education. 1

The resultant high literacy rates for both countries are consistent with and necessary to the achievement of modern economic growth according to Kuznets findings.

For the CANs on the other hand, each indicator illustrated failure to achieve the expectations of a nation in transition to modern economic growth. All five nations were unable to sustain aggregate growth when they encountered the combination of internal and external stresses in the latter 1970s. The Central American Common Market began obviously disintegrating in the last year of the decade of the 1960s, and continued to fall away as a functioning entity through the 1970s. The inability to compel structural development either through the planned integration scheme or through the creation of a regional common market organization, with authority beyond that of the individual nations meant that decisionmaking took place essentially on subnational levels. Regional decisionmaking never took place. It had always been strictly subject to individual national approval, and national decisionmaking was done on the historically established basis of the interests of the oligarchy, the elite, who were in control of the nations. Both the original designs for growth and the internal and external challenges of a decade or two later were understood from the point of view of the sub-national interests.

During the period of increase in total output for the CANs The increase in GDP per Capita was disappointingly small. Since the collapse of GDP in Central America in the 1970s, GDP per capita collapsed also, of course, and has not increased since. The sectoral indicators, an important one in the Kuznetsian scheme, show clearly that no significant change took place in any of the five nations either before or after the collapse. The nearly complete lack of response to the collapse in those indicators, as

\footnotetext{
1 Paul W. Kuznets. "An East Asian Model for Economic Development". Economic Develonment and Cultural Change, Vol. 36. Number 3. April 1988. page S20 and S27.
} 
well as to the original growth in output, underscores the lack of permeability of the social and economic structure.

Private consumption per capita increased very slightly prior to the collapse but then in all cases either returned to the level of fifteen or twenty years earlier, or fell even lower. That too is inconsistent with the expectations for development established by Kuznets. But beyond that, as was discussed above, according to occasional studies, the income distribution in the region, already highly inequitable, worsened during the post-World War II period. Thus the implications of a slight increase or decrease in consumption per capita under those circumstances are not what they would be in a development environment. In reality, among the CANs, private consumption is primarily a function of the small number of wealthy and the administrative element of the population, not of the population as a whole.

Consumption as a part of GDP starts very high among the CANs, 75 to 80 percent, and stays high for all the nations. In two cases it climbed to well over 80 percent in the latter 1980s. Savings, of course, reflects the consumption figures. With the exception of Costa Rica, savings as a percentage of GDP decreased during the period, as did domestic investment, in spite of the high rate of external borrowing during the period.

The rates of literacy, the final indicator in the array, further substantiate the pattern. During the time the ENICs were investing heavily in education and training for the populations of their countries, the CANs were making token efforts which were consistent with the widely held view that education for the majority of the population is a luxury. As discussed in previous chapters, the Costa Rica case is very different from that of the other four CANs. There, universal education has been actively pursued since shortly after World War II. In the other four countries literacy increased by a few percentage points during the twenty years after 1960. The latest data, however, 
that for El Salvador, shows that illiteracy illiteracy actually increased among children in the nation between 1975 and 1980 .

The data illustrates that although the Central American nations enjoyed more than twenty years of economic growth following World War II, they did not develop, they underwent no transformation of the economy to approach modern economic growth. What the Central American nations accomplished during that period is perhaps more likely described as a retardation of industrialization comparable to that written about by Robert Clower, et al in Growth Without Development: An Economic Survey of Liberia. 2

The situation in Central America is comparable in many ways to that of Liberia as described by Clower. A look at the growth in Liberia from 1950 to 1960 suggested to Clower that

sustained economic (expansion) widely shared among the population is likely to occur only if a major share of income gains... is devoted to policies of structural change and development - education, public administration, and industrial and agricultural research and extension. Only in this way is there any hope of creating the skilled and reliable workers, effective managers and administrators, and widespread knowledge and use of efficient production techniques necessary for sustained growth of per capita income. ${ }^{3}$

This statement about Liberia in 1966 applies very well to Central America nearly 30 years later. At this point the 'East Asian Model' as described by Paul Kuznets even more accurately presents the development pattern for underdeveloped nations beginning the transition with characteristics which are very similar to those of the Central American nations.

\footnotetext{
2 Robert Clower. George Dalton. Mitchell Harwilz and A.A. Walters, Gmwth Withoul Develonmenl: An Economic Survey of Liheria, Evanston. Norhwestem University Press, 1966.

${ }^{3}$ Robert Clower, George Dalton. Mischell Harwitz and A.A. Walters. op. eil.. page 40.
} 


\section{IN CENTRAL AMERICA: THE YIELD OF GROWTH}

The data for four of the five Central American nations reveals no developmental movement toward a Kuznetsian modern economic growth. Those nations, El Salvador, Guatemala, Honduras and Nicaragua, underwent a period of simple economic growth during the 1960s and 1970s which many expected to automatically transform the region. The published expectation was that aggregate growth alone would cause the five small economies to become independent, developed economies which were capable of being managed for the benefit of the population as a whole.

Unlike in the case of the ENICs, however, the necessary institutions were not developed, nor was investment made in the population as a whole through education, entrepreneural incentives or physical infrastructure. By far the largest benefit of the increased income went to a few individuals and families rather than the nation as a whole or the population in the larger sense, such as would have been necessary for development of the economy. As described in earlier chapters, this was accomplished through refusal to effectively tax wealth and substantial incomes, through the availability of low interest loans on a large scale only, through incentives for technologically efficient development rather than for labor inclusive processes, and other such policies. Even the early increases in the GDP per capita figures were statistical phenomena rather than real increases in welfare for the majority of the population.

The lack of significant structural change in the three sectors for all five nations is clear from the data. The implications of the use-of-output data is not so clear, on the other hand. That data, which changes, where it changes at all, in the wrong direction for development, represents decisions made in the interests of a small part of the population of each nation. All three elements of the use of output included in this 
study, depict the function of a small economic and political elite and a tiny middle class. Thus they tend to indicate responses of self interest to the economic turning points, rather than responses of concern for national interest.

Consumption, for example, is not constrained in favor of savings and investment. With the exception of Costa Rica the CANs experienced decreased savings and decreased investment over the twenty year period represented, with consumption as a part of GDP which actually increases in a couple of cases. The important question of how that consumption and lack of saving was distributed cannot be answered. The data is simply not available. Strong suggestion is found, however, in data collected occasionally by interested local groups and international agencies.

A $1989-90$ study conducted by the United Nation's Economic Commission for Latin America and the Caribbean (ECLAC) found that the numbers of people living in poverty in the region had increased by twenty percent or more since 1970 . The study reported that "Thousands of middle class families (in Central America) have joined the ranks of the poor and the already poor have dropped into abject poverty. " 4 The ECLAC study calculated the percentages of people living in poverty in the region as follows.

$\begin{array}{lc}\text { Country } & \begin{array}{c}\text { Percentage of people living } \\ \text { below the poverty line. }\end{array} \\ \text { Costa Rica } & 40 \% \\ \text { El Salvador } & 86 \% \\ \text { Guatemala } & 87 \% \\ \text { Hunduras } & 68 \% \\ \text { Nicaragua } & 80 \%\end{array}$

Some challenge even those figures. Honduran Catholic Bishop Raul Corriveau is reported to have disagreed with the Honduran government estimate from which came

\footnotetext{
${ }^{4}$ Central Ameritan Renort. Guatemala City. Inforpress Cuntroamericana. Vol. XVII, Number 30. August 10. 1990 page 233.
} 
the $68 \%$ figure above. Corriveau reports a church study which puts the figure in Honduras at $95 \%$, with $35 \%$ in the extremely poor catagory. 5

For the most part these and other such figures are not directly useful to a study such as this, except to indicate, in the complete absence of consistent and dependable data over time, that none argue that the Central American nations are better off or even as well off as they were prior to the growth of two and three decades ago. The only argument is how much worse are the conditions in those nations. The array of positions range from that of the individual governments who argue that conditions are only very bad, to that of the private international agencies who state that they are disasterous and have been for some time. There is clearly no argument that in any sense have conditions improved since the 1960s.

Early in the development process, the policymakers in Taiwan made the decision to take advantage of the abundance of labor, the prime competitive advantage of the country at the time, by developing the labor force to supply the emerging industrial base. That meant a large national investment in education, and it meant encouraging the development of the small industry which suited the conditions of the country at the time.

During the same period the Central American policymakers universally made the decision to invest in imported technology rather than in domestic capacity. In the context of the Central American Common Market all five nations adopted policies which encouraged importation of high cost, labor saving technology which seemed to allow the avoidance of investment in the population. An extensive Brookings Institution study of 1978 cites such policy decisions as central to the already

\footnotetext{
5 "Central American Summit Focuses on Scxial lssues". Times of the Americus. Washington D.C.. December 25.
} 1991. 
degenerating economic growth record in the region. ${ }^{6}$ William Cline states in that work that the major focus of policy during the 1960s and 1970s "had only a limited impact on the generation of new jobs - yielding new positions for perhaps three percent of the labor force in the region." He goes on to say that in reality the gain was "possibly even less in view of the sectoral shift toward capital intensive industry", replacing the more labor intensive industry which existed earlier. ${ }^{7}$

In one of the studies presented in the Brookings text the authors describe the long standing unemployment and underemployment problem in the region as having been "aggrevated by what has been referred to as labor-saving technological change in the main productive sectors of the economy, including agriculture." 8 The importance of the issue addressed in their own study, say the authors, is "the emphasis that has been placed on technological change as a source of economic growth." They found that the focus on technology "has had an implicit bias against the use of labor." 9

The essential policy recommendations of the Brookings study included abandonment of the "traditional practice in Central America" of maintaining low interest rates and other direct and indirect subsidies for the importation of technology. The authors argued as well against the direct reduction of wages, the standard and ongoing policy response to unemployment questions in the region. The suppression of wages was seen to be unwise because of the already unrealistically low level of wages

\footnotetext{
${ }^{6}$ William R. Cline and Enrique Delgado. Editors. Economic Integration in Central America, Washington. D.C., The Brookings Institution, 1978.

7 William Cline and Enrique Detgado, op. cit.. page 406-407.

8 Charies R. Frank. Max A. Soto and Carlos A. Sevilla. "The Dentand for Labor in the Manufacturing Industry in Central America", in Cline and Delgado, op. cit., page 127.

${ }^{9}$ Frank, et al, op. cit.. pages 134 and 157.
} 
in the region, and also because of the "very low share of wages in the industrial value added in Central America." 10

The economic program undertaken in Central America after World War II was one of growth, measured by the increase of GDP, not development. In terms of the conclusions from the many studies of the process by Simon Kuznets, a serious problem of growth without structural change, that is, without development, is that it is not sustainable. The experience in Central America following World War II appears almost as an illustration of that conclusion.

The German Press Agency (DPA) reported recently that a number of Central American organizations are urging new development models. The Commission for Development and the Environment for Latin America and the Caribbean is cited as having stated that "After more than a half century of deficient growth... we are at a total standstill. ...The grave economic crises are products of an exhausted model of economic growth." The Commission concluded saying that the governments "have not undertaken (the necessary) profound political, economic and social reforms. "11

\section{COSTA RICA: GROWTH OR DEVELOPMENT?}

Although Costa Rica stands out among the Central American nations as economically better off and politically far more stable, it is still catagorized among the underdeveloped nations of the world. In the smoothed data for the indicators in chapter nine, Costa Rica also registers conformation with the expectations for development in four of the eleven catagories. Thus it stands as distinct from the other four CANs

\footnotetext{
10 William Cline and Enrique Delgado, up. cil.. page 164 to 171.

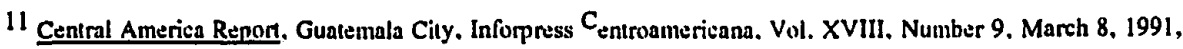
pages 70 and 71 .
} 
where no single indicator registers in conformation with the expectations for the transformation of the economy toward development.

It is important to note that in the case of Costa Rica three of the four conforming indicators occur in the use-of-output catagory. Those are consumption, savings and investment as percentages of GDP. Neither consumption nor investment per capita registered as conforming. It other words, neither consumption nor investment increased on a per capita basis at a rate which would be considered appropriate in a developing economy. Under those circumstances, the fact that consumption as a part of GDP decreased, becomes no more than nominally a development indicator. The decrease of consumption as a percentage of GDP fails to suggest a structural change in consumption patterns when consumption per capita does not increase at the same time.

A similar argument should be made with respect to investment. In view of the fact that investment increased only slightly on a per capita basis, due to a considerable extent to the GDP collapse of the 1970s and 1980s, the fact that investment increased as a part of GDP becomes weakened as an indicator of structural change. A related phenomenon with respect to investment there, is that Costa Rica has much more successfully courted both foreign aid and foriegn investment since the collapse than have the other four nations. In other words, there is reason to believe that the relatively stronger performance in the realm of investment is at least in part a function of its continued attractiveness to foreign capital.

Closely related to the reasons for that attractiveness is the fourth conforming development indicator, the record of literacy. Costa Rica is a nation which has a record of relatively successful political democracy which extends back approximately 150 years as an official phenomenon, to the period of independence from Spain. But the democratic nature of the nation of small farmers in a region of plantation 
agriculture antedates the independence from Spain. The colony was considered a completely useless backwater among the marginally productive colonies of the isthmas. It was considered to be unworthy of either attention or expenditure on the part of Spain. So habits of democratic government are recorded even under Spanish rule.

It is that national character which accounts in considerable part for the high achievements in literacy. An immediately post-World War II liberal government sponsored universal education as socially important. Education was promoted financially as an alternative to a standing army, and the military was disbanded. There is still no standing army in Costa Rica. This is in dramatic distinction from the other Central American nations where the prime purpose of the national armed forces is the control of the populace.

Hence one of the prime explanations of the attractiveness of Costa Rica to foreign capital. In spite of an economic collapse which was as dramatic as that in the rest of Central America, the political situation remained stable and political decisions continued to be made through the essentially democratic processes.

In spite of the literacy, however, and in spite of the record of investment, the signs of development are weak. Sectoral change is central to the transition process to be expected in the Kuznetsian format, and there was little recorded for Costa Rica. GDP showed intermittent, though not sustained, growth and GDP per capita had still not achieved its pre-collapse level ten years later. The country has many developmentally attractive attributes, and it may even be a strong candidate for development in the future, but in terms of this study there is little to suggest that development was either intended or accomplished in Costa Rica in the decades following World War II.

The Costa Rican example does illustrate the importance of the complete pattern of indicators for representation of economic development. The accomplishment of a 
developed economy requires the absorption of science and technology to the extent that the entire economy functions on an industrialized basis. That implies the transformation of the economy so that a high rate of literacy is coupled with a high consumption per capita, though consumption as a percentage of GDP has decreased to allow for more than twenty five percent of the GDP to be invested. That structure rests on a total output of which agriculture is a small part and industry contributes substantially.

That Costa Rica appears as an anomaly in this study suggests rich ground for further research. On the one hand it appears that Costa Rica may be on the route to development without the industrialization necessary to the Kuznetsian scheme. On the other hand industrialization is not the only indicator by which Costa Rica fails the test of development. With further pursuit of the study, however, it may be determined that the bi-polar structure suggested in this study - either growth or development - is an excessive simplification of the possibilities for a sustainable economic expansion.

Another disection for research which the author discovered in the development of this study is the role of external debt in the growth or development of a economy. Some experimentation with the statistics of external debt for each of the seven countries resulted in some suggestive correlations with others of the indicators and with some of the historical events of the post-World War II period, national, regional and global.

In Taiwan, for example, external debt was reduced to a minimum early in the development campaign through domestic savings and investment. As a result the economy was not seriously impacted by the global debt crisis of the 1970s and following. In fact Taiwan became a net foreign lender during that period while South Korea was struggling with external debt. The CANs, on the other hand, already heavily indebted when the global debt problems emerged, were seriously crippled by it 
at a time when many other of the problems of growth without structural change were innundating them.

A third interesting possibility for further research relates to the data which is coming available on the direct incorporation of science and technology as a policy issue into the development process. Taiwan, for example, began collecting data in the late 1970s on research and design (R\&D) expenditures by type, by institution, by field of research, and so on. These and other data gathering efforts in South Korea and other newly industrializing nations suggest the viability of a project which extends the set of development indicators to include a science and technology variable directly, rather than representing it indirectly through education.

\section{FINAL COMMENTS}

It is clear that there are many other valid explanations for the failure of the CANs to achieve success in the growth effort in the latter part of this century. It is equally clear that there are many reasons for the development success of the ENICs during the same period. Many of the alternative explanations were explored in chapter four.

And yet it remains necessary to provide policy guidance for the Central American economies, all of whom are still in crisis. While the alternative explanations considered in chapter four provide important historical insights, none of them, whether taken individually or as a group, provide the understanding that governing the economic development of a nation is akin to guiding the emergence of a new industry. Many economic policymakers still fail to comprehend the complex management process through which the ENICs built industrialized economies from the dependent agricultural economies of the $1950 \mathrm{~s}$. 
In recent years there has been a good bit of interest in understanding the development success of Taiwan and South Korea. The Central American governments among others, with the blessing of U.S. and international agency economists, have waxed enthusiastic about export-led growth again, pointing to the experiences of the east asian economies as justification for their enthusiasm. What is left out of such discussions is that export-led growth describes something that has taken place in Central America since the colonial period.

Export-led increase, in other words, was only one aspect of a complex development process in the ENICs. In both cases a carefully orchestrated period of internal development preceeded the export phase of the process. It was only after an internal economy had been planted and nurtured to some strength that the economies were opened to the global market. And at that the opening took place in phases. In the case of Taiwan, when the "export substitution" phase was initiated in the early 1960s the economy was much changed from ten years earlier. ${ }^{12}$

Land reform and infrastructure projects had made agriculture a strong contributor to the internal economy as well as to export earnings, literacy was all but universal, income equity was well along in its climb to among the highest in the world, and manufacturing for internal demand had increased several-fold. Against this background the export substitution phase was inagurated. Industrial growth was still being financed through primary exports supplemented by foreign aid. But through the following ten years industrial exports based on low-skilled labor replaced both the primary exports and the foreign aid. By the end of the 1960s the labor market had

\footnotetext{
12 The following writers refer to the second major policy phase in Taiwan as the "export substitution" phase. This is the period when industrial exports based on unskilled labor are intentionally substituled for the traditional primary exports. See Figure 6-1 in chapter 6 for specifie reference to that period. Also see. John C.H. Fei. Gustav Ranis and Shirley W.Y. Kuo. Growth wilh Equily: The Taiwan Case. New York. Oxford University Press. 1979. pages 26 ff. Also see a recent survey by The Economist. "A Change of Face: A Survey of Taiwan", October 10, 1992 (Special Research sevition).
} 
entered what Fei et al describe as the condition of labor scarcity, high wages, and exports based on increasingly higher levels of skill and capital intensity.

This is not the approach to export-led growth being contemplated by the Central Americans at present. The simple promotion of exports by the five nations amounts essentially to the continuation of a growth-type policy without likelihood of either improved welfare for the population or industrialization in keeping with the concept of modern economic growth.

To a considerable extent the question revolves around the concept of comparative advantage. As Pack and Westphal put it in a 1986 article, "The neoclassicals have popularized an essentially static theory of comparative advantage." 13 Pack and Westphal argue instead that in the latter part of the twentieth century and beyond, industrial strategy is a matter of managing change to achieve dynamically effective industrialization. Such a pursuit of dynamic comparative advantage, they say, requires the government to take an active role in fostering an appropriate development process, and that distributional issues and intersectoral balance of supply and demand are key in that process. ${ }^{14}$ In a more recent article Westphal pointed out that this is the strategy used by South Korea since the 1960s. It is one of creating comparative advantage in some industries while exploiting the already existing comparative advantage in others. 15

As was made apparent in earlier chapters in discussions of the theorists, no one proposes the role of government in the development process to replace the market. W. Arthur Lewis and others who saw the neoclassical theory as a starting place for policy,

13 H. Pack and L.E. Westphal, "Industrial Strategy and Technological Change: Theory Versus Reality", Journal of Develonment Economics. Vol. 22. 1986, page 90.

14 H. Pack and L.E. Westphal, op. cit.. pages 125 and 91.

15 Larry E. Westphal. "Industrial Policy in an Export Propelled Economy: Lessons from South Korea's Experience". Joumal of Economic Perspectives, Vol. 4. Number 3. Summer 1990, page 53. 
not as a tightly constrained replacement for judgement, insisted that the inclusion of the perspectives of other disciplines is necessary to guidance of the development process.

Some, including Albert O. Hirschman and Walt Rostow, suggest that appropriate policy can only be made on the basis of judgement informed by the cultural and historical circumstances of the subject nation. Both argued that leadership must be exercised by the elite on the spot, not through the application of theory from a distance as is suggested by the neoclassicists whose policy recommendations are invariant with respect to neutral policy and dependence on the market.

Paul Kuznets, in the conclusion to his discussion of the East Asian Model of development, points out that two aspects of the model are particularly noteworthy. "One is that policy typically works by influencing rather than replacing private market decisions." The other is that the heavy emphasis on economic expansion, and the public's expectation that that is an ongoing committment on the part of the government, "means that dynamic rather than static considerations are paramount, and dynamic efficiency is a topic about which the traditional neoclassical paradigm has surprisingly little to say." 16

The outcome of this study argues for the intentional management of a developing economy. Through intervention the ENICs transformed the structures of their economies. These were economies which in the middle of the century were dominantly agricultural, dualistic importers of industrial goods. They were transformed into primarily industrial economies with highly equitable income distribution and a high level of literacy and skills in the population. The ENICs are concluding the century with economies which are competing aggressively in the global industrial market. In the terms of Kuznets and Rostow, both Taiwan and South Korea

\footnotetext{
16 Paul Kuznets, op. cit., page S36 and S37.
} 
have successfully incorporated the current level of science and technology into the majority of the national production.

The five CANs did not undertake intervention for the purpose of development of either the national or the regional economies. The last vestage of the intentional development scheme for the region, a scheme which was created and supported with the help of the United Nation's Economic Commission for Latin America, was quashed soon after 1960. As shown through the indicators in the last chapter, the aggregate growth in the 1960s and the 1970s was not supported by the changes in structure which would have been necessary to either industrialization or continued aggregate increase.

The CANs left investment decisions to market processes. Which is to say that in the final analysis there was no long range policy in the interest of the nations as units. Thus, with the exception of Costa Rica, no investment was made in education or skills for the important labor input in industrial production.

Consumption of GDP continued to be high, and investment and savings continued to be low. As a result, there is reason to suggest that the nations actually increased their vulnerability to external impacts and their dependence on foriegn support. As the subsistence aspects of the economies were traded for dependence on imported industrial production, the ability to adjust to changes in the global economy decreased. Thus the decreased output in the five nations in the late 1970s and 1980s was replaced by dramatic increases in debt.

It is apparent that the growth experiment of the CANs was a calamitous failure. The effort was made in the expectation of gaining benefits through simple economic growth without undergoing the social, political and economic costs of transformation in the supporting economic structure. The result is described by Central American writers as 'the crisis'. 


\section{REFERENCES}

Adelman, Irma and Cynthia Taft Morris, ECONOMIC GROWTH AND SOCIAL EQUITY IN DEVELOPING COUNTRIES, Stanford Univ. Press, Stanford, 1973.

Adelman, Irma and Cynthia Taft Morris. SOCIETY, POLITICS AND ECONOMIC DEVELOPMENT, The Johns Hopkins University Press, Baltimore, 1967.

Adelman, Irma and Erik Thorbecke. THE THEORY AND DESIGN OF ECONOMIC DEVELOPMENT, Johns Hopkins University Press, Baltimore, 1966.

Adelman, Irma. THEORIES OF ECONOMIC GROWTH AND DEVELOPMENT, Stanford University Press, Stanford, 1961.

Agarwala, A.N., S.P. Singh, Eds. THE ECONOMICS OF UNDERDEVELOPMENT, Oxford University Press, NY, 1963.

Alfaro, Jose Miguel, et al. CENTRO AMERICA: CONDICIONES PARA SU INTEGRACION, FLACSO, San Jose, 1982.

Allen, Robert L. "Integration in Less Developed Areas", KYKLOS, Vol. XIV, \#3, 1961, pages 315-335.

Allen, William R.. INTERNATIONAL TRADE THEORY: HUME TO OHLIN, Random House, New York, 1969.

Anderson, Thomas. POLITICS IN CENTRAL AMERICA, Praeger, New York, 1982, revised in 1988.

Bacha, E.L. "The Kuznets Curve and Beyond: Growth and Changes in Inequalities", in ECONOMIC GROWTH AND RESOURCES, Vol. 1, Edmond Malinvaud, Ed., St. Martin's Press, New York, 1979.

Balassa, Bela. "Towards a Theory of Economic Integration" KYKLOS, Vol. 14. \#1, 1961.

Balassa, Bela. THE THEORY OF ECONOMIC INTEGRATION, George Allen and Unwin, London, 1962.

Balmori, Diana, Stuart F. Voss and Miles Wortman. NOTABLE FAMILY NETWORKS IN LATIN AMERICA, The University of Chicago Press, Chicago, 1984.

Barry, Tom and Deb Preusch, THE CENTRAL AMERICA FACT BOOK, Grove Press, New York, 1986 
Bawa, Vasant Kumar. LATIN AMERICAN INTEGRATION, Humanities Press, Atlantic Highlands, NJ, 1980.

Beranak Jr., William, and Gustav Ranis, Eds.. SCIENCE, TECHNOLOGY AND ECONOMIC DEVELOPMENT, Praeger Publishers, New York, 1978.

Best, Michael H., "Political Power and Tax Revenues in Central America", JOURNAL OF DEVELOPMENT ECONOMICS, Vol. 3, 1976.

Boulding, Kenneth: ECODYNAMICS: A NEW THEORY OF SOCIETAL EVOLUTION, Sage Publications, 1978.

Boulding, Kenneth. ECONOMICS AS A SCIENCE, McGraw-Hill, New York, 1970.

Boulding, Kenneth. HUMAN BETTERMENT, Sage Publications, Beverly Hills, 1985.

Brada, Josef C. and Jose A. Mendez. "An Estimate of the Dynamic Effects of Economic Integration", THE REVIEW OF ECONOMICS AND STATISTICS, Vol. 70, \#1, 1988.

Brinkman, Richard. "Growth Vs. Development", in SURVEY OF SOCIAL SCIENCE, ECONOMICS SERIES, Volume 2, Frank N. Magill, Editor, Pasadena, Salem Press, 1991, pages 948-955.

Bulmer-Thomas, Victor. THE POLITICAL ECONOMY OF CENTRAL AMERICA SINCE 1920, Cambridge University Press, Cambridge, 1987.

Cardoso, Ciro F.S. and Hector Perez Brignoli, CENTRO AMERICA Y LA ECONOMIA OCCIDENTAL (1520-1930), Editorial de la Universidad de Costa Rica, San Jose, 1977.

CEPAL, INTEGRACION E INDUSTRIALIZACION EN AMERICA LATINA: MAS ALLA DEL AJUSTE, FLACSO, San Jose, 1987.

Chenery, Hollis and Moises Syrquin. PATTERNS OF DEVELOPMENT, 1950-1970, World Bank/Oxford University Press, London, 1975.

Chenery, Hollis B. Ed.. STUDIES IN DEVELOPMENT PLANNING, Harvard University Press, Cambridge, 1971.

Chenery, Hollis, Sherman Robinson and Moshe Syrquin. INDUSTRIALIZATION AND GROWTH, World Bank/Oxford University Press, New York..., 1986.

Chenery, Hollis. STRUCTURAL CHANGE AND DEVELOPMENT POLICY, World Bank/Oxford University Press, London, 1979.

Clark, Cal. TAIWAN'S DEVELOPMENT: IMPLICATIONS FOR CONTENDING POLITICAL ECONOMY PARADIGMS, Greenwood Press, New York, 1989.

Cline, William R. EXPORTS OF MANUFACTURES FROM DEVELOPING COUNTRIES: PERFORMANCE AND PROSPECTS FOR MARKET ACCESS, The Brookings Institution, Washington DC, 1984. 
Cline, William R. and Enrique Delgado, Eds., ECONOMIC INTEGRATION IN CENTRAL AMERICA, The Brookings Institution, Washington D.C., 1978.

Cochrane, James D. "U.S. Policy Toward Recognition of Governments and Promotion of Democracy in Latin America since 1963", JOURNAL OF LATIN AMERICAN STUDIES, Vol. 4, \#2, pages 275-291.

Cochrane, James D. THE POLITICS OF REGIONAL INTEGRATION: THE CENTRAL AMERICAN CASE, Tulane University, New Orleans, 1969.

Cochrane, James D.. "U.S. Attitudes Toward Central American Economic Integration", INTER-AMERICAN ECONOMIC AFFAIRS, Vol. 18, 1964.

Cohen Orantes, Isaac and Gert Rosenthal. "Reflections on the Conceptual Framework of Central American Integration", CEPAL REVIEW, United Nations, First semester, 1977.

Cohen Orantes, Isaac. REGIONAL INTEGRATION IN CENTRAL AMERICA, Lexington Books, Lexington Mass. 1972.

Coleman, Kenneth M. and George C. Herring. UNDERSTANDING THE CENTRAL AMERICAN CRISIS, Scholarly Resources Books, Wilmington, 1991.

Comacho, Daniel y Manuel Rojas B.. LA CRISIS CENTROAMERICANA, Editorial Universitaria Centroamericana, San Jose, 1984.

Cooper, C.A. and B.F. Massell. "Toward a General Theory of Customs Unions for Developing Countries", JOURNAL OF POLITICAL ECONOMY, Vol. 73, October 1965.

Davenport, H.J.. THE ECONOMICS OF ALFRED MARSHALL, Augustus M. Kelley, New York, 1965 (Original Edition, 1935).

Delgado, Enrique. EVOLUCION DEL MERCADO COMUN CENTROAMERICANO Y DESAROLLO EQUILIDRADO, Editorial Universitaria (EDUCA), 1981

Denham, Robert E. "The Role of the US as an External Actor in the Integration of Latin America", JOURNAL OF COMMON MARKET STUDIES, Vol.VII, \#3, March, 1969.

DeWitt, Peter. "The Inter-American Development Bank and Policymaking in Costa Rica", JOURNAL OF DEVELOPING AREAS, Vol. 15, \#1, Oct. 1980, pages 67-81.

Di Marco, Luis Eugenio. INTERNATIONAL ECONOMICS AND DEVELOPMENT: Essays in Honor of Raul Prebisch, Academic Press, New York, 1972.

Dietz, James L. and James H. Street. LATIN AMERICA'S ECONOMIC DEVELOPMENT: INSTITUTIONALIST AND STRUCTURALIST PERSPECTIVES, Lynne Reinner Publishers, Boulder, 1987. 
ECLA. "General Situation and Future Outlook of the Central American Economic Integration Programme", ECONOMIC BULLETIN FOR LATIN AMERICA, Vol.VIII, \#1, March 1963, pages 9-24.

ECLA. DEVELOPMENT PROBLEMS IN LATIN AMERICA, University of Texas Press, Austin, 1970.

Economist Staff, "Human Development", report on the HUMAN DEVELOPMENT REPORT, United Nations Development Program,, New York, 1990. Described in The ECONOMIST, Vol. 315, \#7656, May 26, 1990.

ENVIO (Editors). "Central America Needs 12 Billion", Vol. 8, \# 92, March 1989.

ESAPAC (Escuels Superior De Administracion Publica America Central) LOS INSTRUMENTOS DEL MERCADO COMUN CENTROAMERICANO, ESAPAC, 1965.

Fei, John C. H., Gustav Ranis and Shirley W. Y. Kuo, GROWTH WITH EQUITY: THE TAIWAN CASE, Oxford Univ. Press (for World Bank), New York, 1979.

Fei, John C.H.. "Ideology of Economic Development in Taiwan", in THE EXPERIENCES AND LESSONS OF ECONOMIC DEVELOPMENT IN TAIWAN, Kwoh-ting Li and Tzong-shian Yu, Editors, Academica Sinica, Taipei, 1982.

Feinberg, Richard E. and Bruce M. Bagley. DEVELOPMENT POSTPONED: THE POLITICAL ECONOMY OF CENTRAL AMERICA IN THE 1980s, Westview Press, Boulder, 1986.

Flanders, M. June. "Prebisch on Protectionism: An Evaluation", in ECONOMICS OF TRADE AND DEVELOPMENT, James D. Theberge, Ed., John Wiley and Sons, New York, 1968.

Gallardo, Maria Eugenia and Jose Roberto Lopez. CENTROAMERICA: LA CRISIS EN CIFRAS, FLACSO, San Jose, 1986.

Gillis, Malcolm, Dwight H. Perkins, Michael Roemer and Donald R. Snodgrass. ECONOMICS OF DEVELOPMENT, W.W. Norton and Company, New York, 1983.

Guerra-Borges, Alfredo. "Desarollo Industrial en Centroamerica: Problemas Y Perspectivas", In INDUSTRIALIZACION EN AMERICA LATINA, Edelberto Torres-Rivas and Eckhard Deutscher, Eds., FLACSO, San Jose, 1986.

Guerra-Borges, Alfredo. DESAROLLO E INTEGRACION EN CENTROAMERICA: DEL PASADO A LAS PERSPECTIVAS, CRIES, Mexico, 1988.

Haberler, Gottfried. "International Trade and Economic Development", in ECONOMICS OF TRADE AND DEVELOPMENT, James D. Theberge, Ed., John Wiley and Sons, New York, 1968. 
Haberler, Gottfried. "Terms of Trade and Economic Development", in ECONOMICS OF TRADE AND DEVELOPMENT, James D. Theberge, Ed., John Wiley and Sons, New York, 1968.

Hansen, Roger. CENTRAL AMERICA: REGIONAL INTEGRATION AND ECONOMIC DEVELOPMENT, National Planning Association, Washington DC, 1967.

Herrera, Felipe. "The Inter-American Development Bank and the Latin American Integration Movement", JOURNAL OF COMMON MARKET STUDIES, Vol. V, \#2, December 1966.

Herrick, Bruce and Charles P. Kindleberger. ECONOMIC DEVELOPMENT, 4th ed., McGraw-Hill Book Co., New York, 1983.

Herrscher, Enrique G. "Mutual Causality in Developing Countries", SYSTEMS PRACTICE, Vol. 1, \#3, September 1988.

Hirschman, Albert O. "A Dissenter's Confession: The Strategy of Economic Development Revisited", in RIVAL VIEWS OF MARKET SOCIETY AND OTHER RECENT ESSAYYS, Viking Press, New York, 1986.

Hirschman, Albert O. THE STRATEGY OF ECONOMIC DEVELOPMENT, Yale University Press, New Haven, 1958.

Hogendorn, Jan S. ECONOMIC DEVELOPMENT, Harper and Row, New York, 1987.

ICADIS, LITERATURA EN INGLES SOBRE LA CRISIS, ICADIS, San Jose, 1986.

ICADIS. RAICES Y PERSPECTIVAS DE LA CRISIS, ICADIS, San Jose, 1986.

Inforpress Centroamericana. CENTRO AMERICA 1988, Inforpress Centroamericana, Guatemala, 1988.

Inforpress Centroamericana. LOS EMPRESARIOS CENTROAMERICANOS ANTE LA CRISIS, Inforpress Centroamericana, Guatemala, 1988.

International Monetary Fund. GOVERNMENT FINANCE STATISTICS YEARBOOK, 1988.

Irwin, George and Xabier Gorostiaga. TOWARDS AN ALTERNATIVE FOR CENTRAL AMERICA AND THE CARIBBEAN, George Allen and Unwin, London, 1985.

Iyer, R. Ramalinga, et al. CENTROAMERICA: INDICATORES SOCIOECONOMICOS PARA EL DESAROLLO, FLACSO, San Jose, 1983.

Jaber, Tayseer. "The Relevance of Traditional Integration Theory to Less Developed Countries", JOURNAL OF COMMON MARKET STUDIES, Vol. IX, \#3, March, 1971, pages 254-267. 
Jameson, Kenneth P. and Charles K. Wilber. DIRECTIONS IN ECONOMIC DEVELOPMENT, University of Notre Dame Press, Notre Dame, 1979.

Jonas Susanne. "Masterminding the Mini-Market: US Aid to the CACM", in REVOLUTION IN CENTRAL AMERICA, Stanford Central America Action Network, Eds., Westview Press, Boulder, 1983.

Jonas, Susanne. "Central America as a Theater of Cold War Politics", LATIN AMERICAN PERSPECTIVES, Vol. IX, \#3, Issue 34, Summer, 1982, pages 123-128.

Keesing, D.B. "Outward Looking Policies and Economic Development", THE ECONOMIC JOURNAL, Vol. LXXVII, \#306, June, 1967.

Kibbey, Richard. "The Crisis in Central America: Failure of Economic Growth Theory", INTERNATIONAL THIRD-WORLD STUDIES JOURNAL, to be published in the fall of 1993, Vol. 5, \#4, 1993.

Kindelberger, C.P. "The Rise of Free Trade in Western Europe: 1820-1875, THE JOURNAL OF ECONOMIC HISTORY, Vol. XXXV, \#1, March 1975.

Koo, Hagen. "The Political Economy of Income Distribution in South Korea: The Impact of the State's Industrialization Policies", WORLD DEVELOPMENT, Vol. 12, October 1984.

Kuznets, Paul W. "The East Asian Model of Economic Development", ECONOMIC DEVELOPMENT AND CULTURAL CHANGE, Vol. 36, \#3, April 1988.

Kuznets, Simon. ECONOMIC DEVELOPMENT, THE FAMILY AND INCOME DISTRIBUTION: SELECTED ESSAYS, Cambridge University Press, New York, 1989.

Kuznets, Simon. "Driving Forces of Economic Growth: What Can We Learn from History", WELTWIRTSCHAFTLICHES ARCHIV; REVIEW OF WORLD ECONOMICS, Vol. 116, \# 3, 1980.

Kuznets, Simon, "Modern Economic Growth: Findings and Reflections", AMERICAN ECONOMIC REVIEW, Vol. 63, June, 1973.

Kuznets, Simon. MODERN ECONOMIC GROWTH: RATES STRUCTURE AND SPREAD. Yale University Press, New Haven, 1966.

Kuznets, Simon. "Quantitative Aspects of the Economic Growth of Nations (Part IX, Level and Structure of Foreign Trade)", ECONOMIC DEVELOPMENT AND CULTURAL CHANGE, Vol. 13, \#1, Oct. 1964.

Kuznets, Simon. "Toward a Theory of Economic Growth", in Robert Lekackman, Ed., NATIONAL POLICY FOR ECONOMIC WELFARE AT HOME AND ABROAD, Russell and Russell, Inc., 1961.

Leonard, Jeffery. NATURAL RESOURCES AND ECONOMIC DEVELOPMENT IN CENTRAL AMERICA, Transaction Books, New Brunswick, 1987. 
Leontief, Wassily. "The Structure of Development"' SCIENTIFIC AMERICAN, 1964.

Lewis, W.A. "The State of Development Theory", THE AMERICAN ECONOMIC REVIEW, Vol. 74, \#1, March, 1984.

Lewis, W. Arthur, "The Slowing Down of the Engine of Growth", AMERICAN ECONOMIC REVIEW, Vol. 70, \#4, September, 1980.

Lewis, W. Arthur. DEVELOPMENT PLANNING: THE ESSENTIALS OF ECONOMIC POLICY, George Allen and Unwin, London, 1966.

Lewis, W. Arthur. THEORY OF ECONOMIC GROWTH, George Allen and Unwin, London, 1955.

Li, K.T., with John C.H. Fei and Gustav Ranis. THE EVOLUTION OF POLICY BEHIND TAIWAN'S DEVELOPMENT SUCCESS, Yale University Press, New Haven, 1988.

Li, Kwoh-ting, and Tzong-shian Yu, Eds. EXPERIENCES AND LESSONS OF ECONOMIC DEVELOPMENT IN TAIWAN, Academica Sinica, Taipei, Taiwan, Republic Of China, 1982.

Lindenberg, Marc. "Central America: Crisis and Economic Strategy 1930-1985, Lessons from History", THE JOURNAL OF DEVELOPING AREAS, Vol. 22, \#2, 1988.

Lipsey, R.G.. "The Theory of Customs Unions: A General Survey", THE ECONOMIC JOURNAL, September 1960.

Lipsey, Richard G. "The General Theory of Second Best", THE REVIEW OF ECONOMIC STUDIES (Edinburgh), Vol. 24, 1956-57, pages 11-32.

Little, I.M.D. "Regional International Companies As as Approach to Economic Integration", JOURNAL OF COMMON MARKET STUDIES, Vol. V, \#2, Dec. 1966.

Lizano, Eduardo and L.N. Willmore. "Second Thoughts on Central America: The Rosenthal Report, JOURNAL OF COMMON MARKET STUDIES, Vol. 13, $\# 3,1975$.

Lizano, Eduardo. LA CRISIS DEL PROCESSO DE INTEGRACION DE CENTROAMERICA, Publicaciones De La Universidad de Costa Rica - Seria Economica y Estadistica \#168, San Jose, 1968.

Lizano, Eduardo. ESCRITOS SOBRE INTEGRACION ECONOMICA, Editorial Costa Rica, San Jose, 1982.

Machlup, Fritz. A HISTORY OF THOUGHT ON ECONOMIC INTEGRATION, Columbia University Press, New York, 1977. 
Maier, Steven and James H. Vander Weide. "Capital Budgeting in the Decentralized Firm", MANAGEMENT SCIENCE, Vol. 23, \#4, December 1976.

Marini, Ruy Mauro. DIALECTICA DE LA DEPENDENCIA, Seria Popular Era, Mexico, 1973.

Massell, Benton F. "Export Concentration and Fluctuations in Export Earnings: A Cross-Section Analysis", AMERICAN ECONOMIC REVIEW, Vol. 54, March 1964, pages 47-63.

Meade, J.E.. A NEO-CLASSICAL THEORY OF ECONOMIC GROWTH, Unwin University Books, London, 1961.

Meier, Gerald M and Dudley Seers, Eds.. PIONEERS IN DEVELOPMENT PLANNING, The World Bank, Washington D.C., 1984.

Meier, Gerald M, Ed.. PIONEERS IN DEVELOPMENT PLANNING; SECOND SERIES, The World Bank, Washington D.C., 1984.

Meier, Gerald M. "Free Trade and Development Economics", in VALUE, CAPITAL AND GROWTH, Wolfe, J.N. Ed., Edinburgh Univ. Free Press, 1968, pages 385-414.

Melville, Thomas y Marjorie, TIERRA Y PODER EN GUATEMALA, Editorial Universitaria Centroamericana, San Jose, 1982.

Michealy, Michael. "The Assumptions of Jacob Viner's Theory of Customs Unions", JOURNAL OF INTERNATTIONAL ECONOMICS, Vol. 6, 1976.

Munro, Dana G. THE FIVE REPUBLICS OF CENTRAL AMERICA, Carnegie Endowment for International Peace, 1918.

Myint, H. "The 'Classical Theory' of International Trade and the Underdeveloped Countries", in ECONOMICS OF TRADE AND DEVELOPMENT, James D. Theberge, Ed., John Wiley and Sons, New York, 1968.

Myint, H.. THE ECONOMICS OF THE DEVELOPING COUNTRIES, Hutchinson University Library, London, 1973.

Myrdal, Gunnar. "What is Development", JOURNAL OF ECONOMIC ISSUES, Vol. 8, December 1974.

Myrdal, Gunnar. AGAINST THE STREAM, Pantheon Books, New York, 1973.

Myrdal, Gunnar. ASIAN DRAMA, The Twentieth Century Fund, New York, 1968.

Myrdal, Gunnar. RICH LANDS AND POOR, Harper and Brothers, New York, 1957.

Myrdal, Gunnar. DEVELOPMENT THEORY AND UNDERDEVELOPED REGIONS, 1958. 
Nicholas, Peter. THE WORLD BANK'S LENDING FOR ADJUSTMENT: AN INTERIM REPORT, World Bank Discussion Papers \#34, Washington DC, 1988.

Nugent, Jeffrey B.. ECONOMIC INTEGRATION IN CENTRAL AMERICA, The Johns Hopkins University Press, Baltimore, 1974.

Ohkawa, Kazashi and Gustav Ranis with Larry Meissner. JAPAN AND THE DEVELOPING COUNTRIES, A COMPARATIVE ANALYSIS, Basil Blackwell, New York, 1985.

Ohkawa, Kazushi and Miyohei Shinohara with Larry Meissner. PATTERNS OF JAPANESE ECONOMIC DEVELOPMENT: A QUANTITATIVE APPRAISAL, Yale University Press, New Haven, 1979.

Pack, Howard and Larry E. Westphal. "Industrial Strategy and Technological Change: Theory Versus Reality", JOURNAL OF DEVELOPMENT ECONOMICS, Vol. 22, 1986, (Seoul, Economic Research Institute of Chung An University) pages 87-128.

Park, Yung Chul. "Development Lessons from Asia: The Role of Government in South Korea and Taiwan", THE AMERICAN ECONOMIC REVIEW, Vol. 80, Number 2, May 1990.

Pazos, Felipe. "Regional integration of Trade among LDCs". WORLD DEVELOPMENT, Vol. 1, \#7, 1973.

Pepelasis, Adamantios, Leon Mears and Irma Adelman. ECONOMIC DEVELOPMENT, Harper and Brothers, New York, 1961.

Perez-Brignoli, Hector, "Growth and Crisis in the Central American Economies, 19501980", JOURNAL OF LATIN AMERICAN STUDIES, Vol. 15, Nov. 1983.

Perez-Brignoli, Hector. BREVE HISTORIA DE CENTRO-AMERICA, Alianza Editorial, 1985.

Perkins, Dwight H. and Michael Roemer. REFORMING ECONOMIC SYSTEMS IN DEVELOPING COUNTRIES, Harvard University Press, 1991.

Perroux, Francois. A NEW CONCEPT OF DEVELOPMENT: BASIC TENENTS, UNESCO, New York, 1983.

Prebisch, Raul. "Development Problems of the Peripheral Countries and the Terms of Trade", in ECONOMICS OF TRADE AND DEVELOPMENT, James D. Theberge, Ed., John Wiley and Sons, New York, 1968.

Ramsett, David E., REGIONAL INDUSTRIAL DEVELOPMENT IN CENTRAL AMERICA, Frederick E. Praeger, New York, 1969.

Ranis, Gustav, Ed.. THE UNITED STATES AND THE DEVELOPING ECONOMIES, W.W. Norton and Company. New York, 1964. 
Ranis, Gustav, et al. "Economic Growth/Theory", ENCYCLOPEDIA OF THE SOCIAL SCIENCES, 1979 . pages 395-429 and pages 408-417.

Republic of China, INDUSTRY OF FREE CHINA, Council for Economic Planning and Development, Vol. LXXV, Number 3, March 1991.

Republic of China, MONTHLY STATISTICS OF THE REPUBLIC OF CHINA, Directorate General of Budget, Accounting and Statistics, Number 301, February 1991.

Robert Repetto, "Deforestation in the Tropics", SCIENTIFIC AMERICAN, Vol. 262, \#4, April, 1990.

Robinson, E.A.G., ECONOMIC CONSEQUENCES OF THE SIZE OF NATIONS, St. Martin's Press, Inc., New York, 1960.

Robson, Peter. THE ECONOMICS OF INTERNATIONAL INTEGRATION, George Allen \& Unwin, London, 1980.

Robson, Peter. THE ECONOMICS OF INTERNATIONAL INTEGRATION, George Allen and Unwin, London, 1980.

Roht, Naomi. "Opening Up The Economy-For A Few", REPORT ON GUATEMALA, Vol. 11, \#1, Spring 1990.

Rostow, W.W. THE STAGES OF ECONOMIC GROWTH: A NON-COMMUNIST MANIFESTO, Third Edition, Cambridge University Press, Cambridge, 1990.

Rostow, W.W. THE STAGES OF ECONOMIC GROWTH, Cambridge University Press, New York, 1969.

Ruefli, Timothy W. "A Generalized Goal Decomposition Model", MANAGEMENT SCIENCE, Vol. 17, \#8, April 1971.

Schmitter, Philippe C. "Central American Integration: Spill-over, Spill-around or Encapsulation?", JOURNAL OF COMMON MATKET STUDIES, Vol. IX, \#1, Sept. 1970, pages 1-48.

Schumpeter, Joseph A., THE THEORY OF ECONOMIC DEVELOPMENT, Transaction Books, New Brunswick, 1983.

Scitovsky, Tibor. "Two Concepts of External Economies", in A.N. Agarwala and S.P. Singh, eds., THE ECONOMICS OF UNDERDEVELOPMENT, Oxford University Press, New York, 1963.

Selowsky, Marcelo. "Stages in the Recovery of Latin America's Growth", FINANCE AND DEVELOPMENT, Pub. by IMF and World Bank, Vol. 27, \#2, June 1990.

Shaw, Royce Q. CENTRAL AMERICA: REGIONAL INTEGRATION AND NATIONAL POLITICAL DEVELOPMENT, Westview Press, Boulder, 1978. 
Sheahan, John. "Market Oriented Economic Policies and Political Repression in Latin America", ECONOMIC DEVELOPMENT AND CULTURAL CHANGE, Vol. 28, \#2, January, 1980.

Shearer, Ronald A. "The Concept of Economic Growth", KYKLOS, Vol.XIV, \#4, 1961.

SIECA. LA INTEGRACION Y DESAROLLO EN CENTROAMERICA, FLACSO, Guatemala, 1988.

Singh, V.B.. THEORIES OF ECONOMIC DEVELOPMENT, Somaiya Pubs Ltd., Bombay, ND (Approx. 1970).

Soza, Hector. "The Industrialization Debate in Latin America", CEPAL REVIEW, Santiago, April 1981.

Stiglitz, Joseph E. "Markets, Market Failures and Development", THE AMERICAN ECONOMIC REVIEW, PAPERS AND PROCEEDINGS, Vol. 79, \#2, May, 1989.

Stohl, Michael, and Harry R. Targ. "United States and The Third World: The Struggle to Make Others Adapt", in THIRD WORLD POLICIES OF INDUSTRIALIZED NATIONS, Phillip Taylor and Gregory Raymond, Eds., Greenwood Press, Westport, Conn., 1982.

Streeten, Paul. ECONOMIC INTEGRATION, A.W. Sythoff, Leyden, 1961.

TAIWAN STATISTICAL DATA BOOK, Council for Economic Planning and Development, Republic of China, 1990.

Technological Forecasting and Social Change. Issue on Technology Measurement, Vol. 27, \#2 \& \#3, May, 1985.

Tikhomirov, Vladislav B. NEW INTERNATIONAL DEVELOPMENT STRATEGY: A SYSTEMS ANALYSIS APPROACH, United Nations Institute for Training and Research, New York, 1981.

Todaro, Michael P. ECONOMIC DEVELOPMENT IN THE THIRD WORLD, Second Edition, Longman, New York, 1981.

Todaro, Michael P. ECONOMIC DEVELOPMENT IN THE THIRD WORLD, Fourth Edition, Longman, New York, 1989.

Todaro, Michael P. "Current Issues in Economic Development", in ECONOMIC PERSPECTIVES: AN ANNUAL SURVEY OF ECONOMICS, Maurice B. Ballabon et al, Eds., Vol.1, 1979, Harwood Academic Publishers, New York, 1979.

Torres-Rivas, Edelberto. "The Central American Model of Growth: Crisis for Whom?", LATIN AMERICAN PERSPECTIVES, Vol. VII, \#2 \& 3, 1980. 
Torres-Rivas, Edelberto. CENTROAMERICA: LA DEMOCRACIA POSIBLE, Editorial Universitaria Centroamericana, San Jose, 1987.

Torres-Rivas, Edelberto. CRISIS DEL PODER EN CENTROAMERICA, EDUCA, San Jose, 1989.

Toye, John. DILEMMAS OF DEVELOPMENT, Basil Blackwell, New York, 1987.

United Nations Development Program, HUMAN DEVELOPMENT REPORT, United Nations, New York, 1990.

United Nations Development Program, Prepared by the Regional Bureau for Latin America and the Caribbean, SPECIAL PLAN OF ECONOMIC COOPERATION FOR CENTRAL AMERICA, Final Draft Version, April, 1988, Internal Document.

United Nations Development Program, Prepared by the Regional Bureau for Latin America and the Caribbean, EL SALVADOR: COOPERACION PARA EL DESARROLLO, Informe, 1989.

United Nations Development Program, Prepared by the Regional Bureau for Latin America and the Caribbean, GUATEMALA: COOPERACION PARA EL DESARROLLO, Informe, 1989.

Viner, Jacob. INTERNATIONAL TRADE AND ECONOMIC DEVELOPMENT, The Free Press, Glencoe, Ill., 1952.

Viner, Jacob. THE CUSTOMS UNION ISSUE, Carnegie Endowment for International Peace, New York, 1950.

Wade, L.L. and B.S. Kim. ECONOMIC DEVELOPMENT OF SOUTH KOREA, Praeger, New York, 1978.

Weaver, James and Kenneth Jameson. ECONOMIC DEVELOPMENT: COMPETING PARADIGMS, University Press of America, Inc., Lanham, MD., 1981.

Weekly, James K. "Towards a Central American Capital Market", JOURNAL OF COMMON MARKET STUDIES, Vol. VII, \#2, Dec. 1969.

Weeks, John. THE ECONOMIES OF CENTRAL AMERICA, Holmes and Meier, New York, 1985.

Weeks, John. "An Interpretation of the Central American Crisis", LATIN AMERICAN RESEARCH REVIEW, Vol. 21 \#3, 1986.

Westphal, Larry E., "Industrial Policy in an Export Propelled Economy: Lessons from South Korea's Experience", JOURNAL OF ECONOMIC PERSPECTIVES, Vol. 4, \#3, Summer, 1990.

Willmore, L.N. "Free Trade in Manufactures among Developing Countries: The Central American Experience", ECONOMIC DEVELOPMENT AND SOCIAL CHANGE, Vol. 20, \#4, July, 1972. 
Wionczek, Miguel S. "The Rise and the Decline of Latin American Economic Integration", JOURNAL OF COMMON MARKET STUDIES, Vol. IX, \#1, Sept. 1970, pages 49-66.

Wionczek, Miguel, Ed.. ECONOMIC COOPERATION IN LATIN AMERICA, AFRICA AND ASIA, MIT Press, Cambridge, 1969.

Wionczek, Miguel. "Latin American Integration And U.S. Economic Policies", Robt. W. Gregg, Ed. INTERNATIONAL ORGANIZATION IN THE WESTERN HEMISPHERE, 1968.

Woodward, Robert Lee. CENTRAL AMERICA: A NATION DIVIDED, Oxford University Press, New York, 1976.

World Bank Staff, Prepared by Country Operations Division Department II - Latin America and the Caribbean, TRADE LIBERALIZATION AND ECONOMIC LIBERALIZATION IN CENTRAL AMERICA, Internal Document - Report \# 7625-CAM, 1990.

World Bank Staff, Prepared by Country Operations Division Department II - Latin America and the Caribbean, EL SALVADOR: COUNTRY ECONOMIC MEMORANDUM, Internal Document - Report \# 7818-ES, August, 1989.

World Bank, The. WORLD DEVELOPMENT REPORT-1989: FINANCIAL SYSTEMS AND DEVELOPMEMT, Oxford University Press, 1989

World Bank, The. WORLD DEVELOPMENT REPORT-1991: THE CHALLENGE OF DEVELOPMENT, Oxford University Press, 1991

World Bank, The. WORLD DEVELOPMENT REPORT-1992: dEVELOPMENT AND THE ENVIRONMENT, Oxford University Press, 1992

World Bank, The. WORLD TABLES-1978, The Johns Hopkins University Press, Baltimore, 1978.

World Bank, The. WORLD TABLES-1990, The Johns Hopkins University Press, Baltimore, 1990.

World Bank. THE WORLD BANK RESEARCH PROGRAM, 1988, The World Bank, Washington DC, 1989.

Wynia, Gary W. POLITICS AND PLANNERS: ECONOMIC DEVELOPMENT POLICY IN CENTRAL AMERICA, University of Wisconsin Press, Madison, 1972

Wynia, Gary W. POLITICS OF LATIN AMERICAN DEVELOPMENT, Cambridge University Press, Cambridge, 1978

Zimmerman, L. J., POOR LANDS, RICH LANDS: THE WIDENING GAP, Random House, New York, 1965. 


\begin{abstract}
APPENDIX
DATA USED FOR THE GRAPHS: CALCULATED FROM THE SOURCES GIVEN IN THE TEXT
\end{abstract}



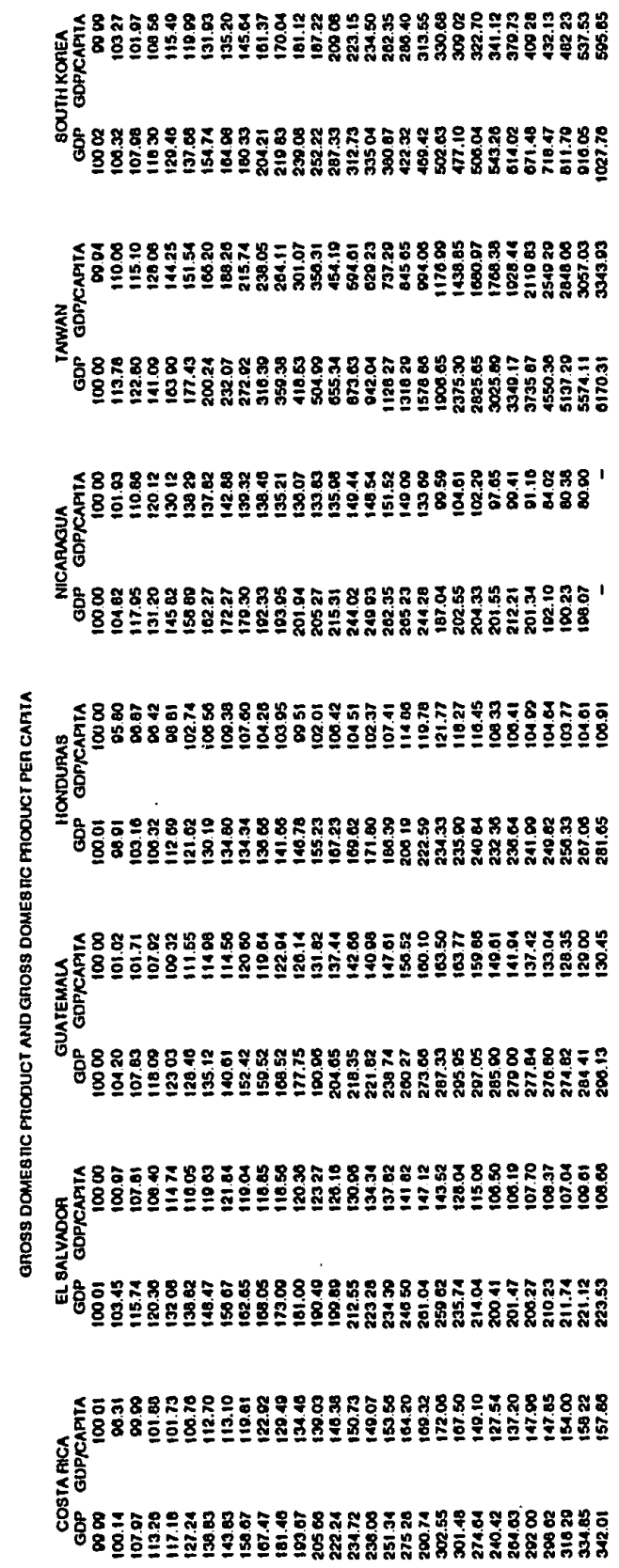

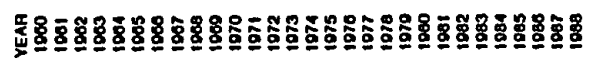




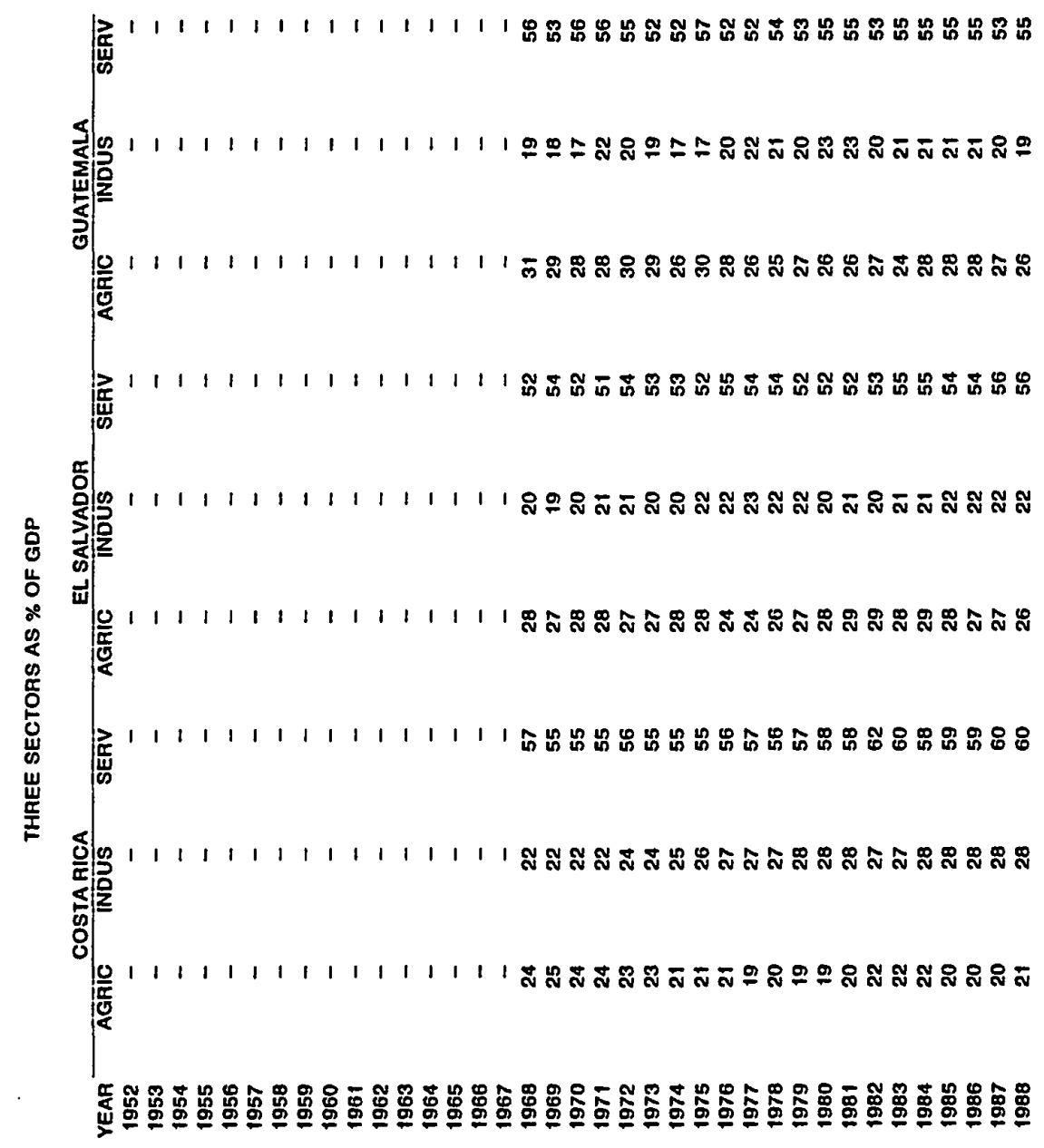




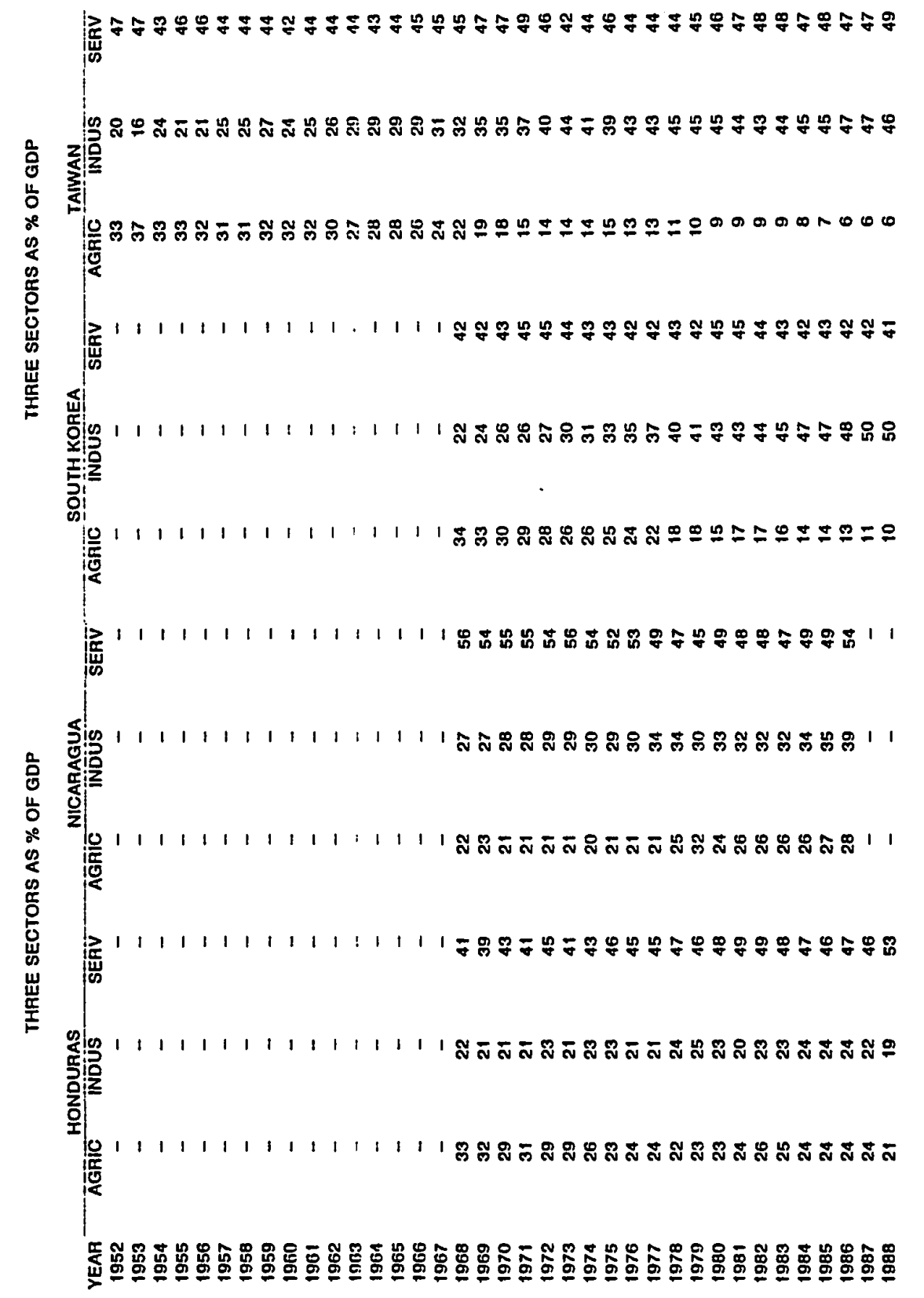




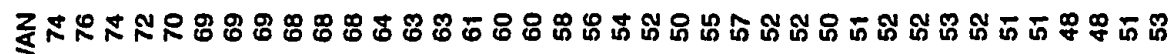
产

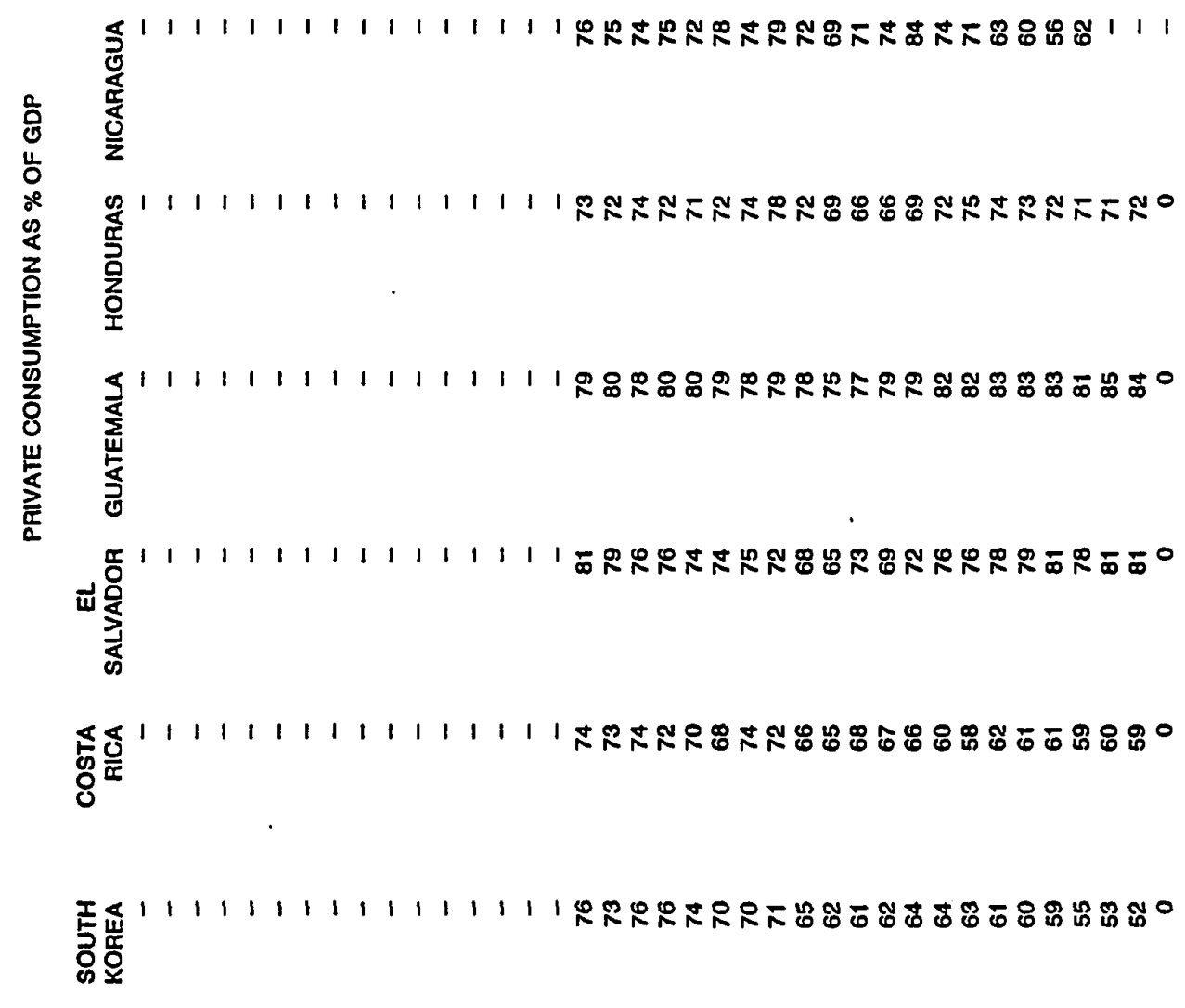

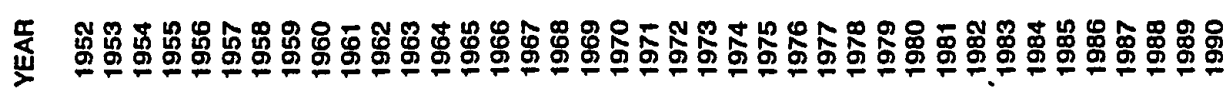




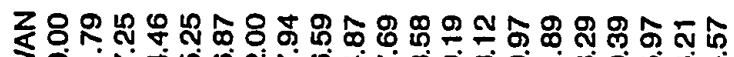

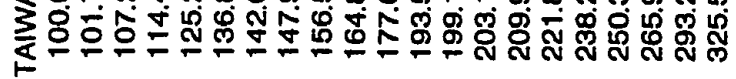

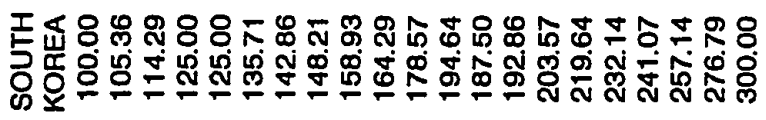

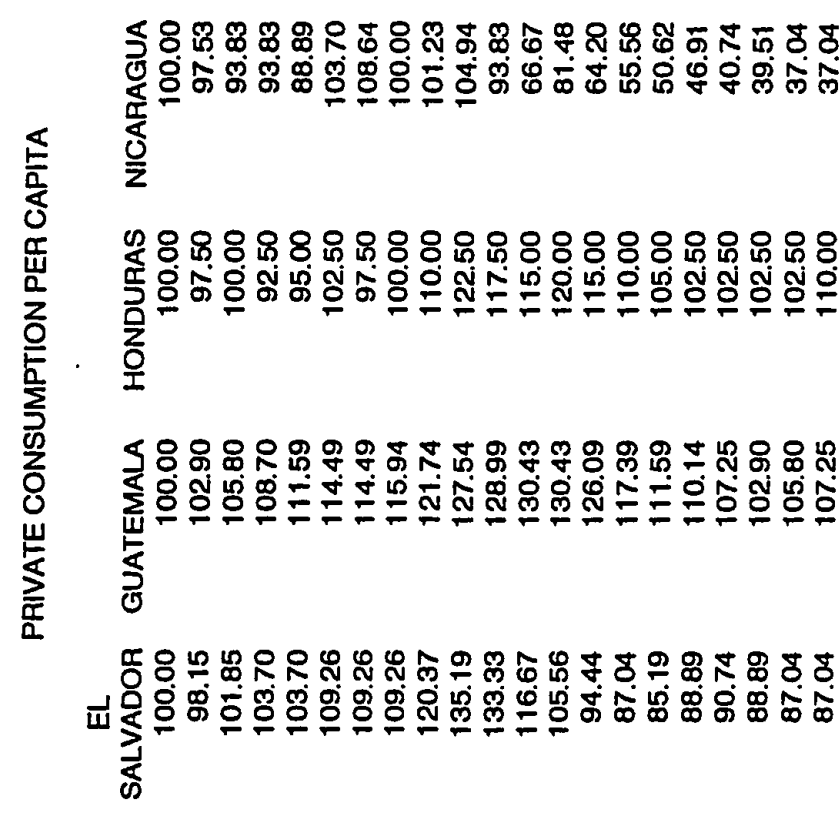

Łరำ

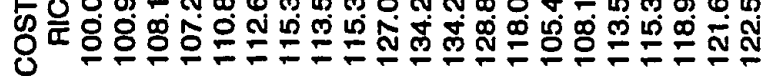

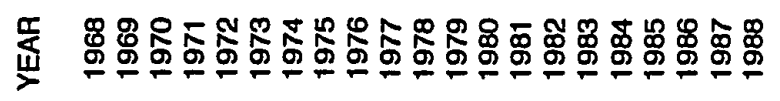




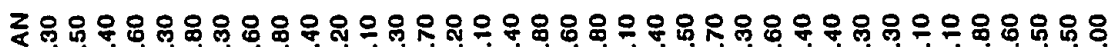

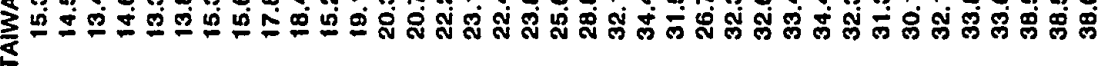

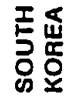

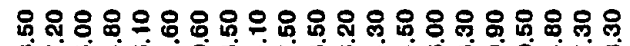

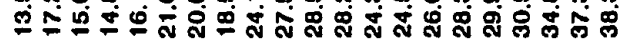

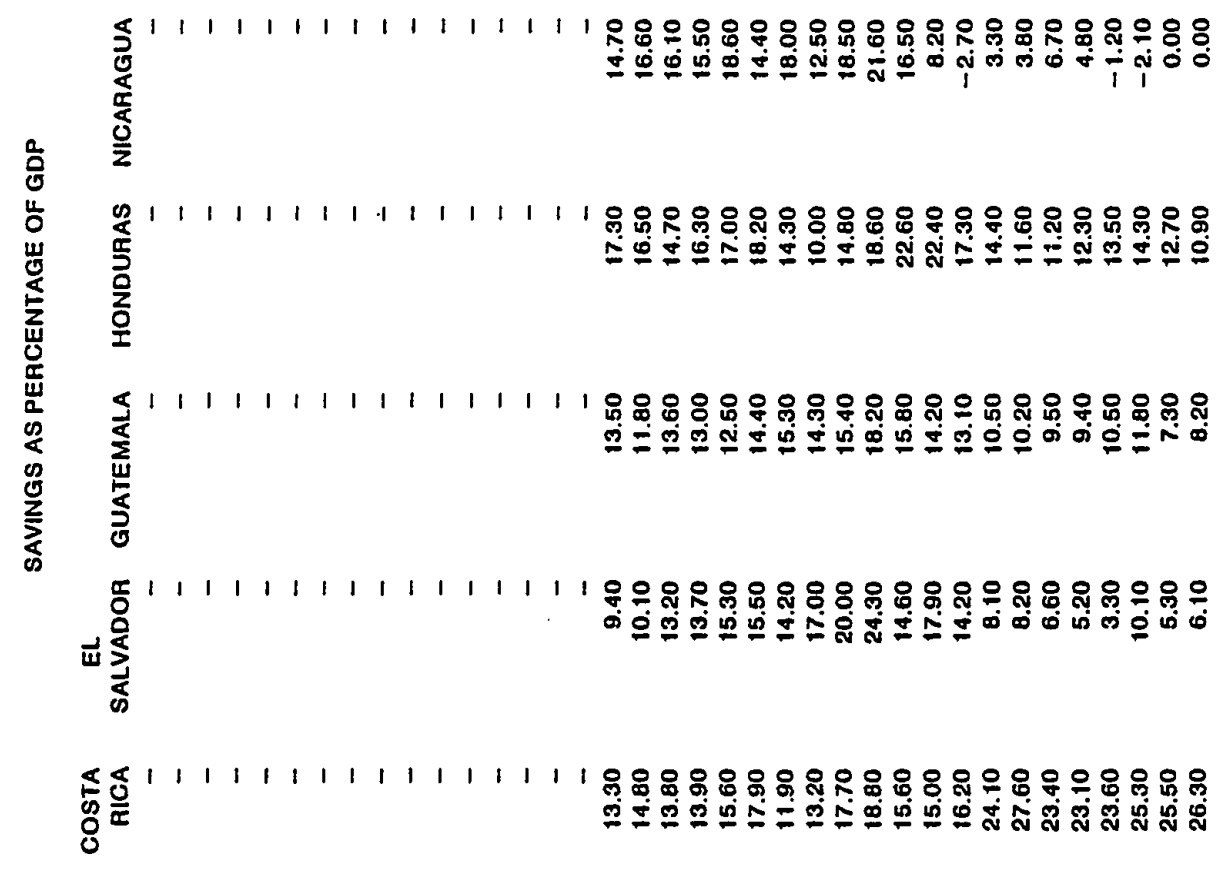

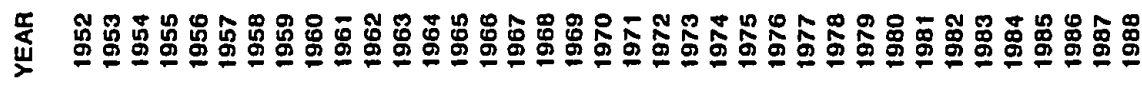




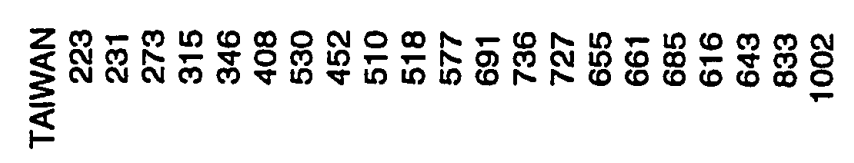

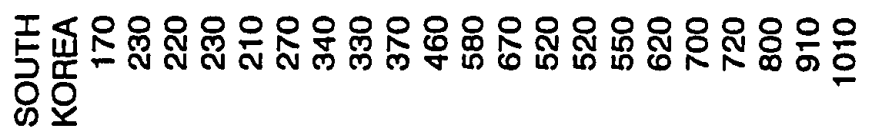

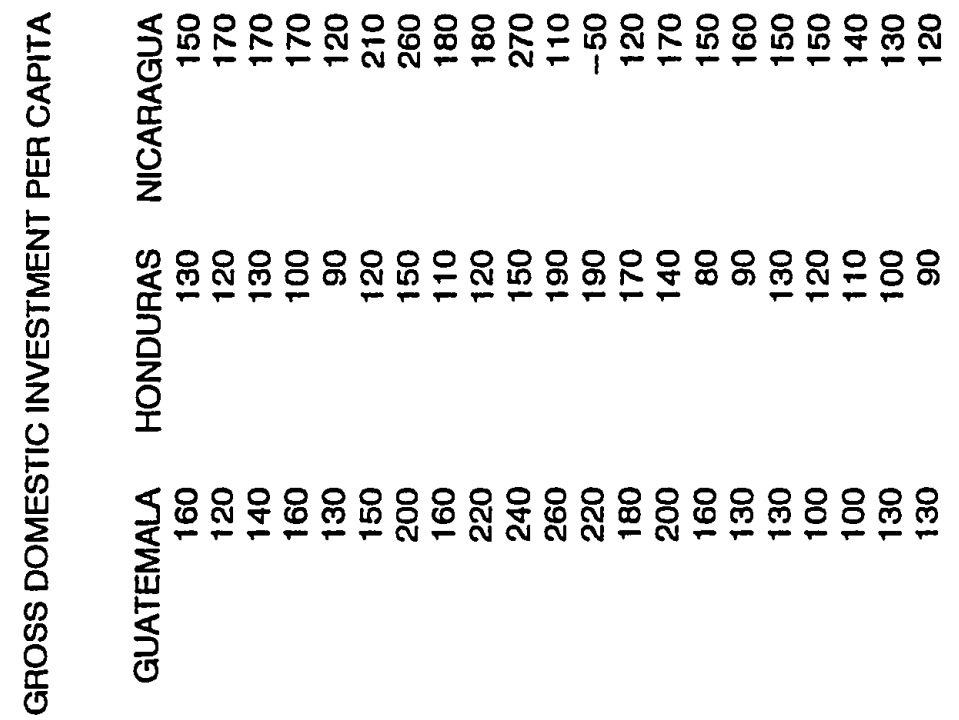

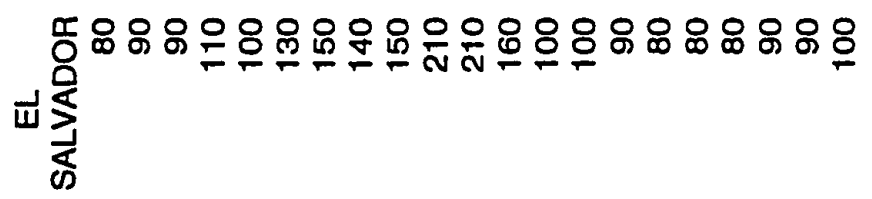

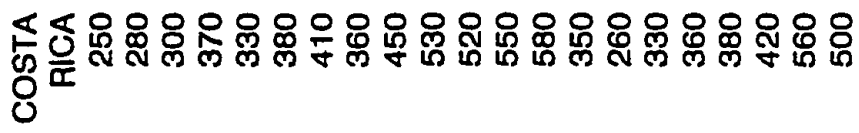

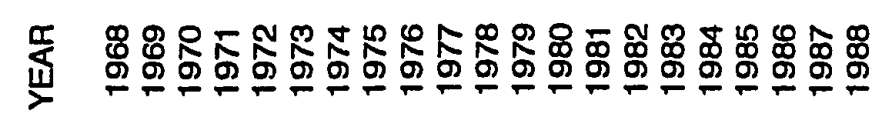




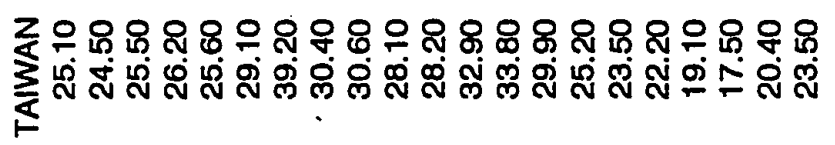

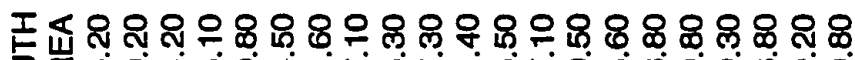

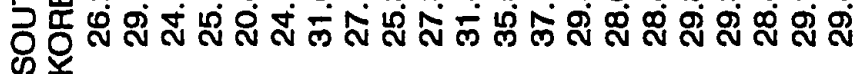

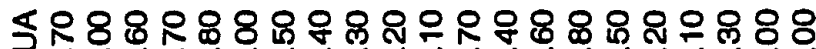

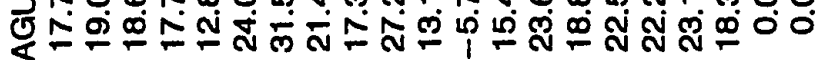

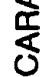

付

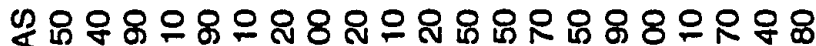

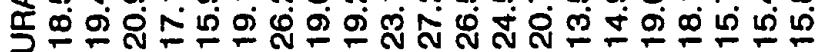
宅

오

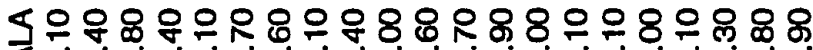

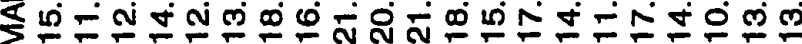

崖

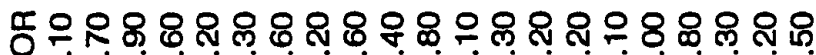

Шे

药

ङ

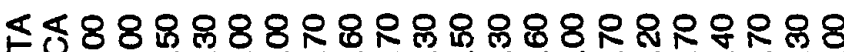

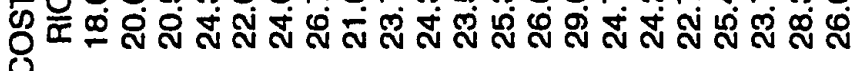

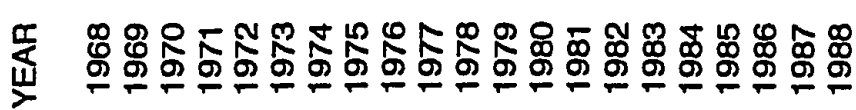




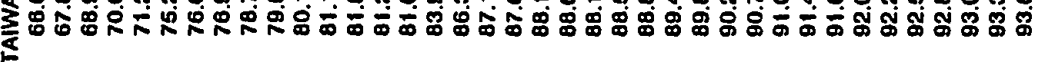

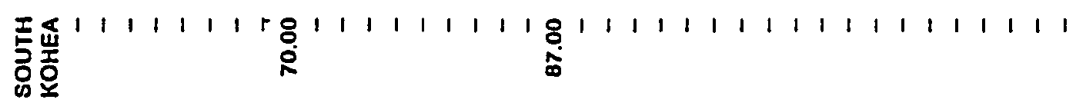

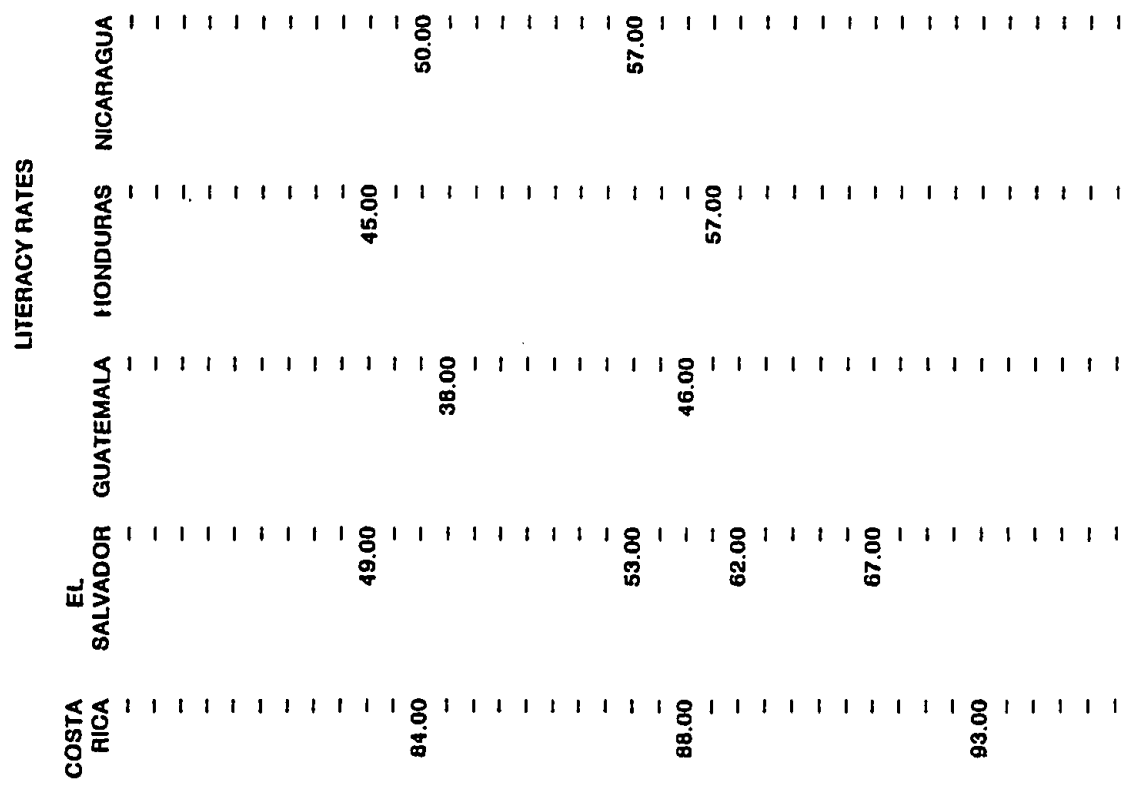

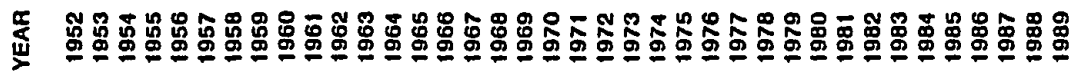



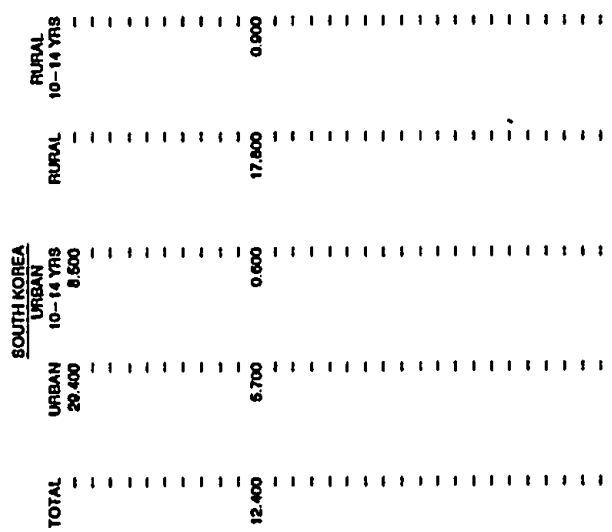

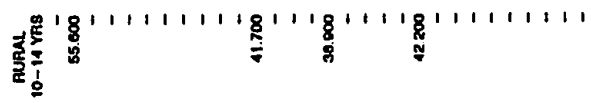
年然

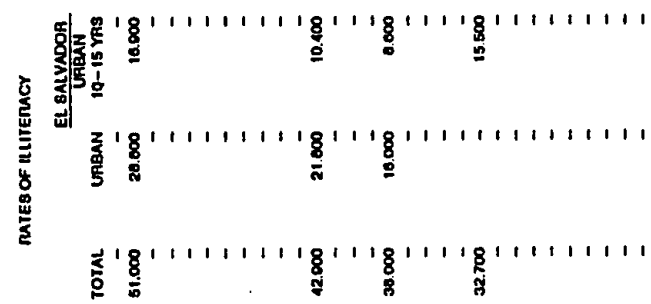

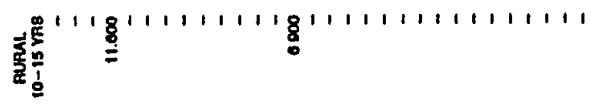

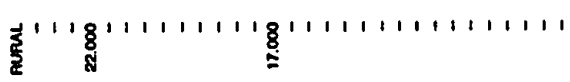

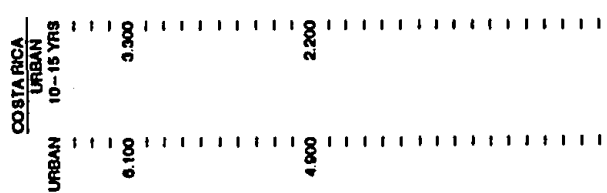

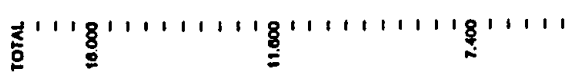

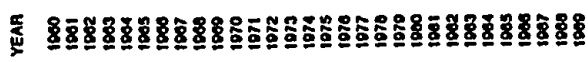

